$$
\begin{aligned}
& \text { UNIVERSIDADE DE SÃO PAULO } \\
& \text { INSTITUTO DE GEOCIÊNCIAS }
\end{aligned}
$$

\title{
CONTAMINAÇÃO E ÁREAS DE RESTRIÇÃO DE USO DE ÁGUA SUBTERRÂNEA NO ENTORNO DO CANAL JURUBATUBA EM SÃO PAULO - SP
}

\author{
Emanuel S. P. L’Apiccirella
}

Orientador: Prof. Dr. Reginaldo A. Bertolo

\section{DISSERTAÇÃO DE MESTRADO}

Programa de Pós-Graduação em Recursos Minerais e Hidrogeologia

SÃO PAULO

2009 
Aos meus pais, Carlos e lgnez, à minha esposa, Danielli e aos meus irmãos, Carlos, Francisco, Nadime e Arany. 


\section{EPÍGRAFE}

"Os problemas ambientais nascem na relação entre os seres humanos e a natureza. Da forma como se apresentam hoje, eles parecem não ter solução, pois fazem parte de uma crise contínua e crescente que é também ética, estética e econômica, além de ambiental. Trata-se, pois, de uma crise de valores. Estamos na era do ocaso do especialista, e um caminho na direção contraria parece desejável. A partir disso, tenta-se mostrar como se pode entrever, no ambiente, uma lógica do ambiente que está em contraste com a lógica da cultura. [...] um estudo das origens em geral, associado a uma "psicanálise global", poderá indicar alguns caminhos para que, através de uma nova linguagem, possam vir à tona "interesses do cidadão terrestre". Isso, porém, só ocorrerá, efetivamente, se os seres humanos se tornarem autênticos agentes da história da Terra, seres do presente, porém integrados ao passado e à construção do futuro. O conceito de ambiente corresponde, etimologicamente, a "ir em volta pesquisando vontades". No seu sentido mais amplo, portanto, ambiente se refere a perguntas existenciais e políticas, relacionadas aos desejos humanos, e perguntas materiais objetivas, relacionadas aos ciclos dos materiais terrestres, os ciclos geoquímicos. [...] Se quisermos estudar o ambiente com um referencial histórico, surge uma dificuldade. Na definição das origens, há várias alternativas: para o cosmólogo temos 150 milhões de séculos de idade, para o geólogo 46 milhões de séculos, para o biólogo 38 milhões de séculos, para o antropólogo alguns milhões de anos... no limite, está o egoísta, cuja idade máxima está na certidão de nascimento". 


\section{AGRADECIMENTOS}

Este trabalho teve a contribuição e a sustentação de muitas pessoas e instituições, as quais devo lembrar com gratidão e cujos incentivos e ensinamentos assimilo como parte importante de minha formação. Dentre todos, agradeço com especial reconhecimento:

Ao Professor Reginaldo Antônio Bertolo, pela orientação, disponibilidade, confiança e amizade. Agradeço ainda por ter ensinado, na prática, técnicas de condução dos trabalhos, tanto relacionadas à execução técnica quanto à dinâmica de trabalhos em equipe, tendo passado um exemplo fundamental, vista a abrangência do assunto tratado na dissertação.

Ao Professor Ricardo César Aoki Hirata e aos geólogos Mateus Delatim Simonato e Ana Maciel de Carvalho, aos quais devo não apenas agradecer o apoio nos trabalhos, mas também por terem cedido idéias e criações realizadas no âmbito do projeto DAEE-Servmar, muitas das quais foram utilizadas nessa dissertação. Ao Ricardo, agradeço ainda pelos anos que venho tendo o privilégio de tê-lo como professor. Ao Mateus, pela confiança e por apoiar condições, na Servmar, que permitiram conciliar os estudos e o dia-a-dia na empresa. À Ana, pela atenção e grande comprometimento na execução do projeto DAEE-Servmar.

À minha família, pelo permanente e incondicional apoio. À minha esposa, Danielli Gilbert de Souza L'Apiccirella, pela leitura e revisão de língua portuguesa e, também pela atenção e compreensão na fase mais intensa do trabalho.

Ao Instituto de Geociências da Universidade de São Paulo (IG-USP), em especial ao Departamento de Geologia Sedimentar e Ambiental (GSA), no qual esta dissertação foi desenvolvida, através do programa de pós-graduação em Recursos Minerais e Hidrogeologia, na área de concentração de Hidrogeologia e Meio Ambiente.

À Diretoria da Servmar, nas pessoas de Maurício Prado Alves, Leandro de Faria e Maria Herondina R. A. de Faria, pelo incentivo e apoio aos meus estudos.

Ao geógrafo Bruno Pirilo Conicelli, pelo apoio decisivo na produção ilustrativa para a dissertação, além do companheirismo e disposição na fase final de produção.

Aos geólogos Gerôncio de Albuquerque Rocha e José Eduardo Campos, idealizadores e promovedores do "projeto Jurubatuba" na esfera do DAEE, pela convivência, contribuição técnica e aprendizado.

Aos colegas da equipe técnica do projeto DAEE-Servmar Célia Surita, que esteve à frente da execução em boa parte do projeto DAEE-Servmar e Marcio Abreu, também executor daquele projeto.

Ao Eng. Hidráulico Professor Edson Wendland, do Departamento de Hidraulica e Saneamento da USP de São Carlos e, aos geólogos Amélia João Fernandes, do Instituto Geológico, Ingo Wanfried, do IG-USP e, Carlos Birelli, do Instituto de Pesquisa Tecnológicas, pela imprescindível contribuição técnica, convivência e aprendizado. 
Aos executores dos trabalhos de campo no âmbito do projeto DAEE-Servmar, Eng. Ambiental André Pillon, Tec. Ambiental Rodrigo Borges, Alexandre Silva e ao Bernardino Martins Ribeiro, da Poços Artesianos Tupã, pelo profissionalismo e companheirismo.

Às desenhistas Cássia Nascimento e Alessandra Escarante, pela colaboração nas ilustrações iniciais do trabalho.

Aos geólogos Pedro Aronchi Neto, Giovanna Galante e Fabio Stern, que, ao início dos trabalhos, estiveram na equipe do projeto DAEE-Servmar, pela contribuição e aprendizado.

À Divisão de Áreas Contaminadas da CETESB, nas pessoas de Alfredo Rocca, Professora Dorothy Casarini, Elton Gloeden e Vicente Aquino, pelas contribuições técnicas.

Ao Laboratório de Modelos Físicos (LAMO), do IG-USP, pela utilização de sua estrutura e aos geólogos deste laboratório Carlos Maldaner, Claudia Varnier, Ingo Wanfried, Leonardo Marcolan, Sandra Guerra, Tatiana Tavares e Veridiana Martins, pelas discussões, dicas e convivência. 


\section{RESUMO}

\section{L'APICCIRELLA, E. S. P. Contaminação e Áreas de Restrição de Uso de Água Subterrânea}

No Entorno do Canal Jurubatuba em São Paulo - SP. 2009. 136 f. Dissertação (Mestrado) Instituto de Geociências - Universidade de São Paulo, São Paulo.

A região do canal Jurubatuba apresenta uma contaminação de água subterrânea por solventes organoclorados alifáticos, nas zonas mais industrializadas, proveniente de várias fontes. As características de mobilidade, solubilidade e persistência destes organoclorados, em relação aos aqüíferos locais, propiciaram-Ihes alcançar a rede de poços de produção, expondo a população a riscos. Esta situação levou a CETESB, órgão estadual de controle de poluição ambiental, e a COVISA, órgão municipal de proteção à saúde, a atuarem conjuntamente, intensificando investigações ambientais e lacrando poços. Em seguida, o DAEE, órgão estadual gestor dos recursos hídricos, determinou uma "Área de Restrição e Controle Temporário" de uso da água. O objetivo deste trabalho é reconhecer o cenário de contaminação e apresentar uma metodologia para a delimitação de áreas de restrição e controle de uso da água subterrânea. O cenário hidrogeológico e ambiental foi caracterizado utilizando-se de cadastro de poços, bases cartográficas, ensaios hidrodinâmicos e análises químicas, e os dados, tratados em tabelas e gráficos, foram trabalhados em SIG. A área estudada tem $120 \mathrm{~km}^{2}$ e uma população aproximada de 2 milhões de habitantes. Um levantamento de atividades no Sistema de Fontes de Poluição (SIPOL), da CETESB, seguido da aplicação do método Pollutant Origin Surcharge Hydraulically (POSH), permitiu identificar 2.490 Áreas com Elevado Potencial de Contaminação. Verificou-se ainda, a ocorrência de 87 Áreas Contaminadas Declaradas (ACD), sendo 17 delas por estes organoclorados. Foram identificados 513 poços de produção outorgados e, estimado que haja centenas de poços clandestinos. Análises químicas destes organoclorados em 86 poços de produção resultaram em 46 poços com organoclorados, sendo que em 28 destes poços as concentrações estavam acima dos Valores Orientadores de Intervenção. Verificou-se indicações de fontes ativas de contaminação, tais como, poços de monitoramento com concentrações indicativas da presença de organoclorados em fase livre no aqüífero e o modelo de descarte de efluentes, em zona desprovida de coleta de esgoto, que sugere a presença destes organoclorados em galerias ambientalmente irregulares, distribuídas pela área. Com base nos resultados, propôs-se que a Área de Restrição e Controle seja definida considerando a densidade de atividades potenciais de contaminação, as áreas declaradas contaminadas por organoclorados e os poços de produção com ocorrência de organoclorados. Foram observados, ainda, os instrumentos legais aplicáveis para apontar medidas de restrição. A metodologia caracteriza pequenas áreas, 
similares em seus níveis de contaminação potenciais e reais, distinguindo-as em três conjuntos, a partir dos quais são traçadas áreas de Alta, Média e Baixa restrição. O método permite definir medidas de controle para cada nível de restrição e possibilita readequar os limites das áreas se houver variações das características dessas áreas. A Área de Alta Restrição tem $10,75 \mathrm{~km}^{2}$, sendo significativamente menor do que a área de restrição temporária delimitada inicialmente (com $32 \mathrm{~km}^{2}$ ). O resultado foi diminuir as zonas com proibição de uso de água e, simultaneamente, ampliar o tamanho de áreas de menor nível de restrição (totalizando $59,75 \mathrm{~km}^{2}$ de áreas restringidas), implantando controles de regularização de poços e monitoramentos de qualidade da água melhor direcionados, propiciando, portanto, uma utilização segura do aqüífero.

Palavras-chave: Área Industrial. Poço de produção. Contaminação. Gerenciamento. Área de restrição. 


\begin{abstract}
L'APICCIRELLA, E. S. P. Contaminação e Áreas de Restrição de Uso de Água Subterrânea No Entorno do Canal Jurubatuba em São Paulo - SP. 2009. 136 f. Dissertação (Mestrado) Instituto de Geociências - Universidade de São Paulo, São Paulo.
\end{abstract}

The groundwater in the region of the Jurubatuba channel is contaminated by aliphatic chlorinated solvents from various sources especially where the density of industrial activity is high. The contaminants detected are relatively persistent, soluble and mobile and many of them reach the deep supply well system exposing consumers of groundwater to risks. This fact led to CETESB the environmental agency of State of São Paulo and COVISA the municipal health agency to work together intensifying environmental investigations and sealed supply wells. After this, DAEE the water resources management agency of State of São Paulo create a "Temporary Area of Restriction and Control" to regulate the use of groundwater.

The goal is to recognize the contamination scene and provide a methodology for the delimitation of Areas of Restriction and Control to the Use of Groundwater in the area of study. The hydrogeological and environmental scene was characterized by using the cadastre of wells, cartographic databases, hydrodynamic tests and chemical analysis and data were processed in tables and graphs and worked throw GIS.

The area is $120 \mathrm{~km}^{2}$ and has a population of approximately 2 million inhabitants. A survey of activities based in the System of Pollution Sources (SIPOL) followed by the application of the Pollutant Origin Hydraulically Surcharge (POSH) method has identified 2,490 Areas with High Potential for Contamination. There was also the occurrence of 17 Areas Designated as Contaminated by these organochlorines.

There are 513 regulated supply wells and hundreds of illegal supply wells are estimated to exists. The chemical analysis of organochlorines from 86 supply wells detected concentrations in 46 wells and the concentrations were above the Guidelines Intervention Values in 28 wells.

There are evidences of occurrence of active contamination sources such as great organochlorine concentrations founded in monitoring wells which are indicative of organochlorine free phase in the aquifer and also such the type of effluents discharge.

Based on the results obtained it was proposed that the area of restriction and control to the use of groundwater would be defined considering the density of activities with potential contamination Areas Designated as Contaminated by organochlorine and areas with occurrence of supply contaminated by organochlorines. The applicable legal instruments to appoint measures of restriction also were observed. 
The methodology characterizes small areas similar in their levels of actual and potential contamination distinguishing into three sets from which areas of high, medium and low restriction are drawn. The method allows appoint control measures for each level of restriction and allows for readjustment the area boundaries if variations occur in the characteristics of these areas.

The Area of High Restriction is $10.75 \mathrm{~km}^{2}$ being significantly smaller than the temporary restriction area initially defined at $32 \mathrm{~km}^{2}$. The result was to reduce the areas with prohibition of groundwater use and also enlarge the size of lower levels restriction areas (totaling $59.75 \mathrm{~km}^{2}$ of restricted areas) implementing controls to regulate the use of supply wells and providing a better model to monitoring the water quality and therefore a safe use of the aquifer.

Keywords: Industrial Area. Supply well. Contamination. Management. Area of restriction. 


\section{SUMÁRIO}

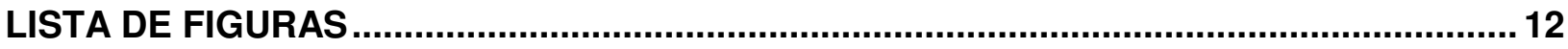

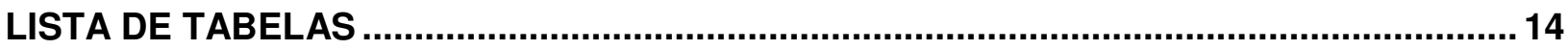

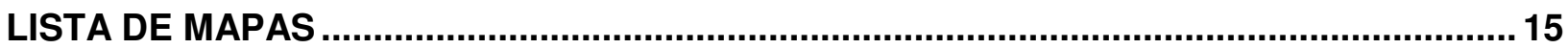

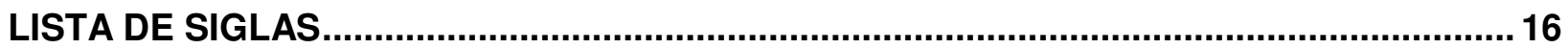

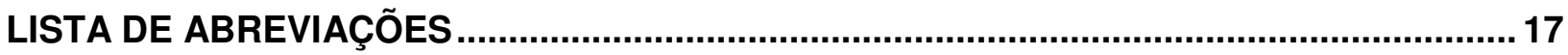

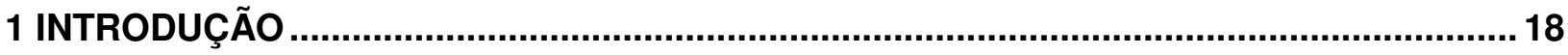

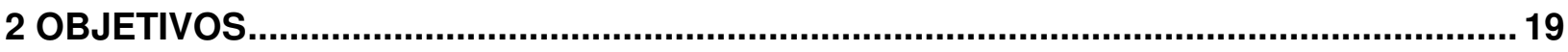

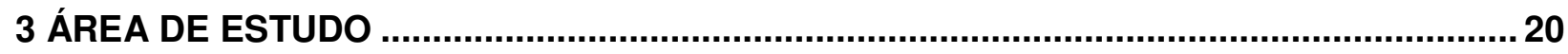

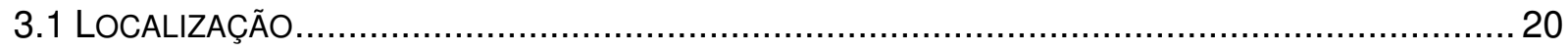

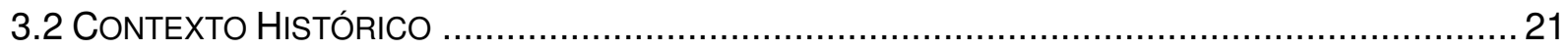

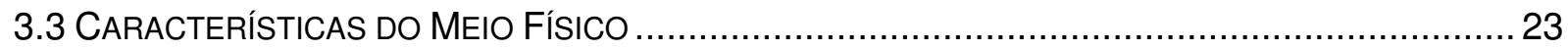

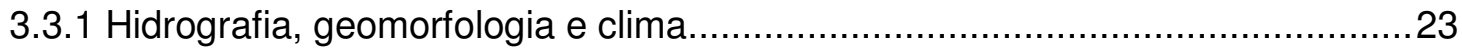

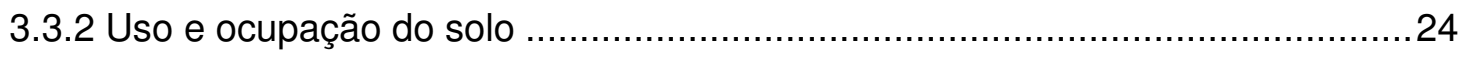

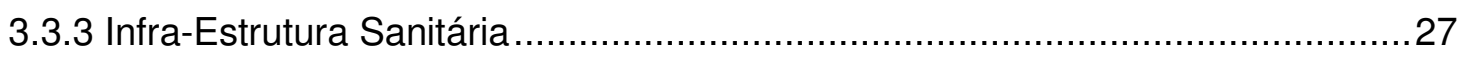

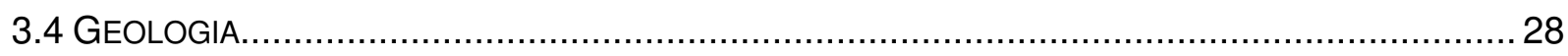

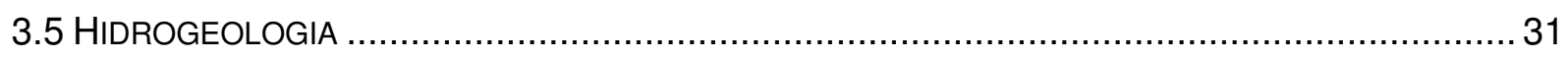

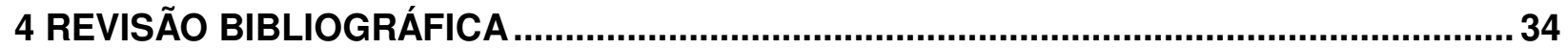

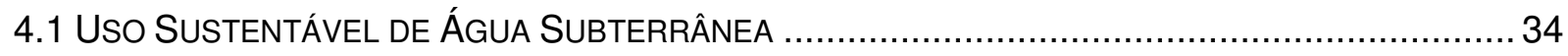

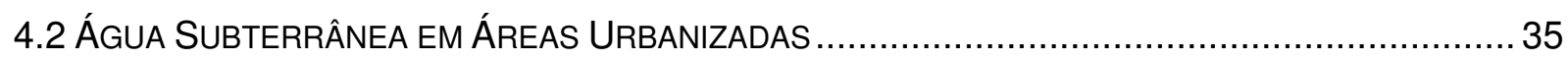

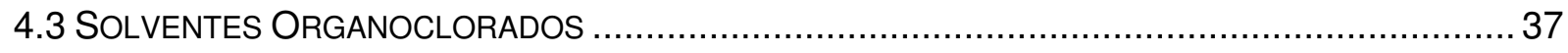

4.4 Solventes ORganoclorados E PoÇOS DE ProduÇÃo .............................................. 38

4.4.1 Comportamento de compostos organoclorados em aqüíferos .........................38

4.4.2 Monitoramento de VOC do Serviço Geológico dos EUA (USGS).....................40

4.4.3 Estudos de caso ............................................................................... 41

4.5 Principais Órgãos GeStORES E LEGISLAÇÃo BrasileIRA APLICADA …......................... 46

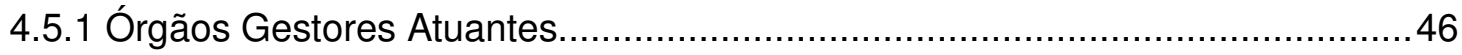

4.5.2 Legislação brasileira aplicada ............................................................... 47

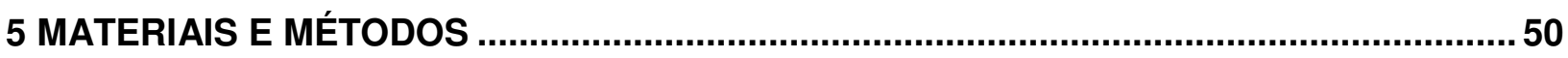

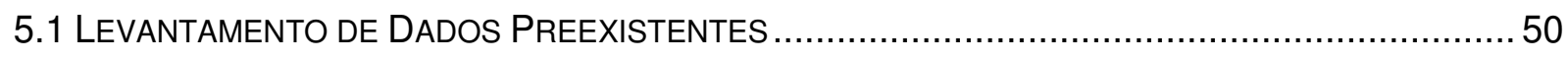

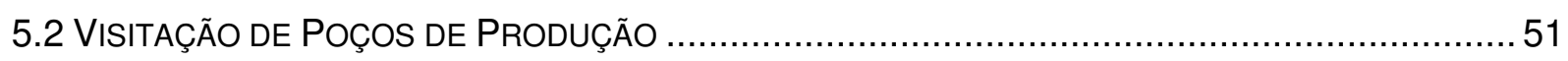


5.3 ENSAIOS DE CAMPO

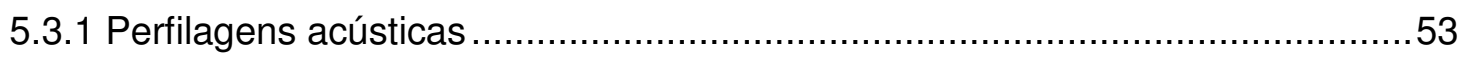

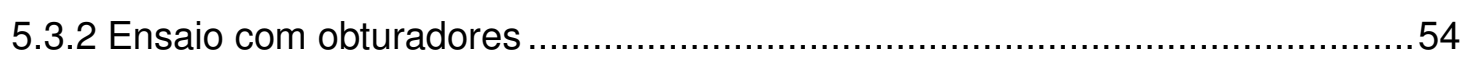

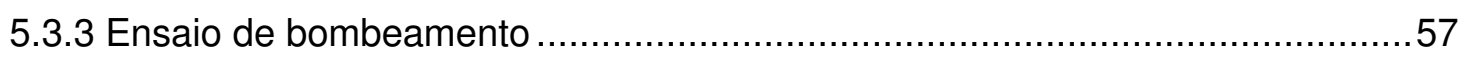

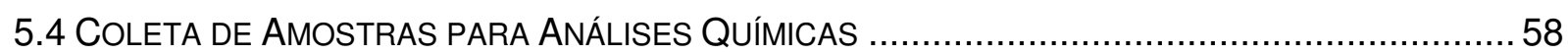

5.5 TRATAMENTO E INTERPRETAÇÃO DE RESULTAdOS ................................................... 60

6 USO DA ÁGUA SUBTERRÂNEA ........................................................................... 62

6.1 CONDIÇÕES DE ESTRUTURA E MANUTENÇÃO dOS PoÇOS .......................................... 64

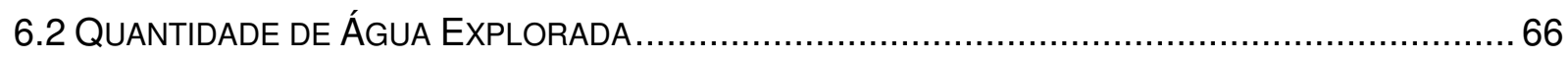

7 MODELO CONCEITUAL HIDROGEOLÓGICO .............................................................. 68

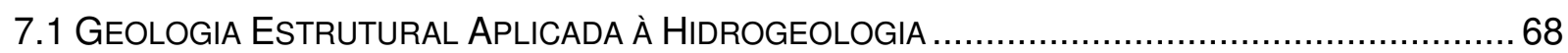

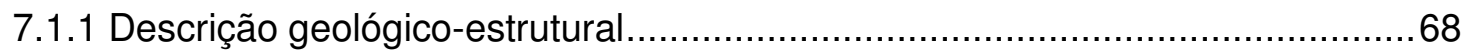

7.1.2 Tratamento e interpretação de dados geológico-estruturais.............................69

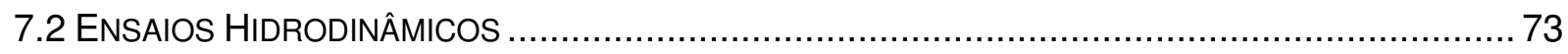

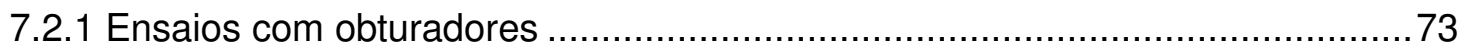

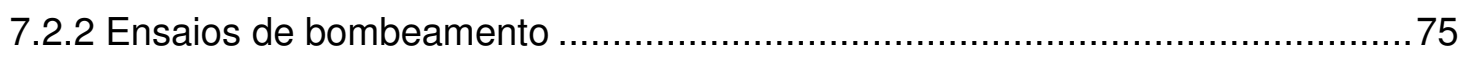

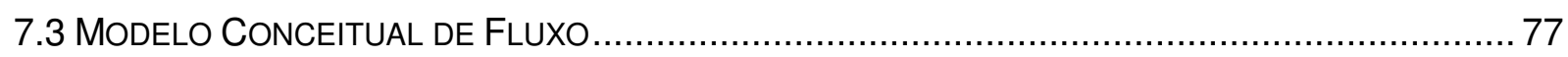

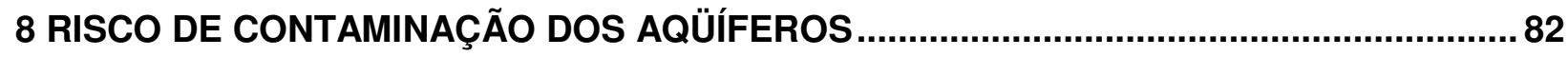

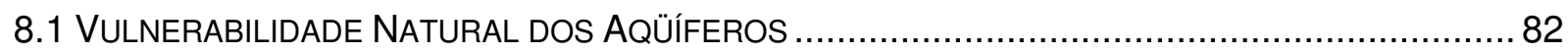

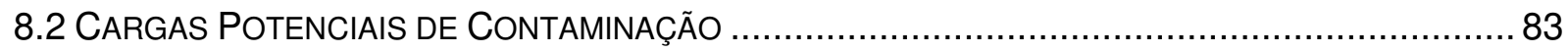

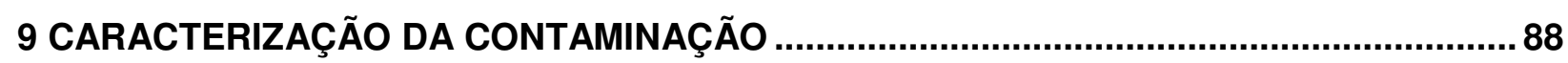

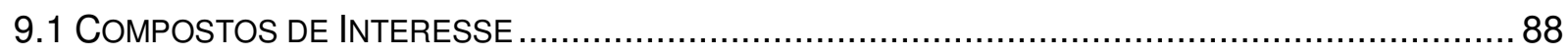

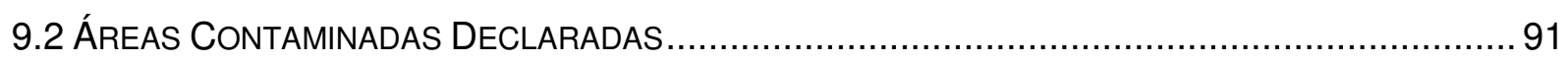

9.3 RESULTAdOS DE ANÁLISES QUÍMICAS DA ÁGUA ........................................................ 96

9.4 CONSIDERAÇÕES ADICIONAIS SOBRE O CENÁRIO DE CONTAMINAÇÃO .............................. 102

10 RESTRIÇÃO E CONTROLE DE USO DE ÁGUA SUBTERRÂNEA ................................. 104

10.1 CRITÉRIOS PARA A DEFINIÇÃo dAS ÁREAS DE RESTRIÇÃO ........................................ 104

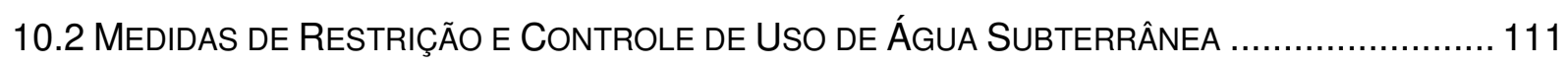

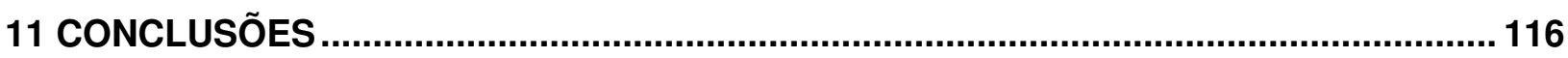

12 REFERÊNCIAS BIBLIOGRÁFICAS ..................................................................... 119

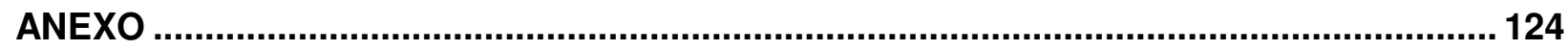




\section{LISTA DE FIGURAS}

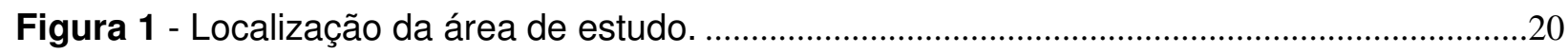

Figura 2 - Histórico de poços interditados. ................................................................................22

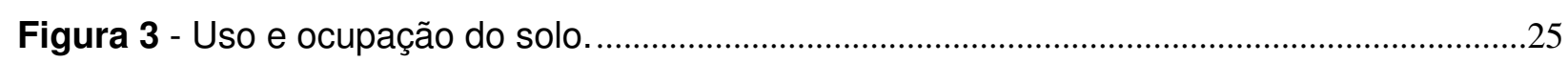

Figura 4 - Mudança de uso e ocupação do solo. Evolução da concentração de indústrias e posterior instalação de novos empreendimentos e condomínios verticais. .....................................26

Figura 5 - Redes de distribuição de água e coleta de esgoto. .........................................................27

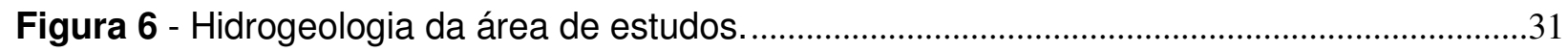

Figura 7- Cadeia de degradação a partir do etano clorado TCA e do eteno clorado PCE..........40

Figura 8 - Distribuição espacial dos poços amostrados e ensaiados em campo..........................52

Figura 9 - Exemplo de imageamento acústico.................................................................................53

Figura 10 - Estrutura do equipamento obturador pneumático........................................................55

Figura 11- Arranjo utilizado na operação de ensaios com obturadores. .........................................56

Figura 12 - Rebaixamento em aqüífero bombeado. ..................................................................57

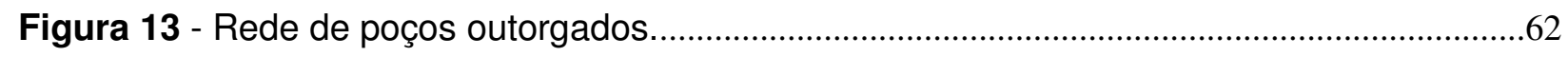

Figura 14 - Sistema aqüífero explorado por poço. .........................................................................63

Figura 15 - Evolução de número de poços construídos por décadas. ............................................63

Figura 16 - Exemplos de poços em bom estado de conservação (a) e de poços mal

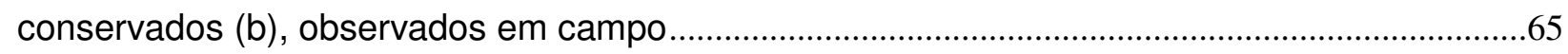

Figura 17 - Distribuição do número de poços em relação ao tipo de uso de água........................66

Figura 18 - Número de poços e vazão de outorga na área de estudo............................................67

Figura 19 - Vazão de outorga dos poços......................................................................................67

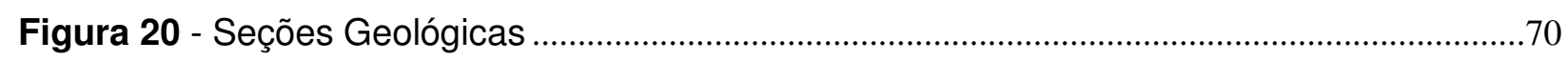

Figura 21 - Gráfico indicando as fraturas de maior ângulo, que predominam em maiores

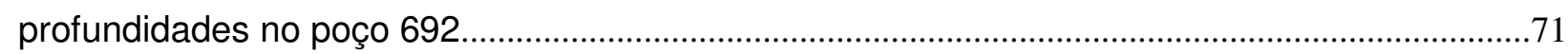

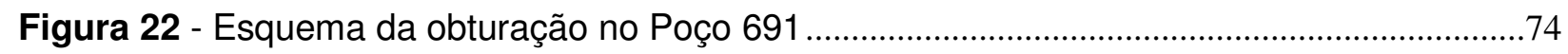

Figura 23 - Rebaixamento do aqüífero cristalino às margens do canal Jurubatuba considerando

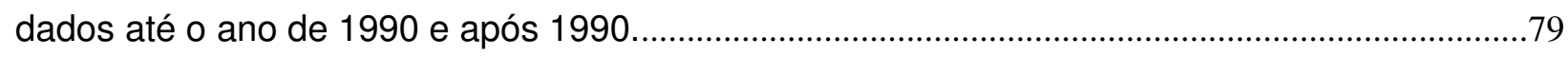

Figura 24 - Nível estático, antigo e atual, da água subterrânea em poços paralisados na área

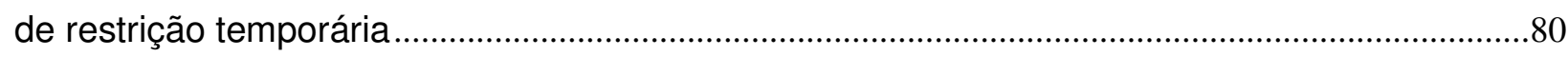

Figura 25 - Modelo Conceitual hidrogeológico. .............................................................................81

Figura 26 - Vulnerabilidade natural dos aqüíferos à contaminação. ..............................................83

Figura 27 - Índices de atividades com carga potencial de contaminação......................................85

Figura 28 - Cadeia de degradação de etenos clorados por decloração redutiva..........................88

Figura 29 - Categorias de áreas contaminadas...........................................................................91 
Figura 30 - Áreas declaradas contaminadas por EEC ou EAC.

Figura 31 - Fontes de contaminação por solventes halogenados alifáticos em áreas industriais.

Figura 32 - Etapas de trabalhos realizadas nas áreas contaminadas por EEC ou EAC............93

Figura 33 - Modelo de galeria com contaminante conectada à rede de galerias pluviais. .95

Figura 34 - Detecções de EEC ou EAC, relacionadas aos Valores Orientadores de Intervenção da CETESB. . .97

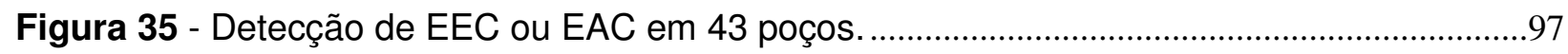

Figura 36 - Concentração de parâmetros em diferentes profundidades amostradas. ................100

Figura 37 - Concentração de parâmetros em diferentes profundidades amostradas. ................101

Figura 38 - Concentração de parâmetros em diferentes profundidades amostradas. ................101

Figura 39 - Pontos de ocorrência de AEPC na grade de 500 m x 500 m. ..................................105

Figura 40 - Distribuição de Densidade de AEPC. .............................................................................105

Figura 41 - Densidade de Áreas com Elevado Potencial de Contaminação (AEPC) nas células

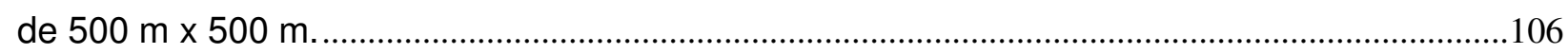

Figura 42 - Elementos para a definição da área de restrição......................................................107

Figura 43 - Modelo conceitual de delimitação da área de restrição no entorno de células.......107

Figura 44 - Configuração dos traçados de áreas de restrição. .......................................................108

Figura 45 - Conformação final das Áreas de Restrição...................................................................109 


\section{LISTA DE TABELAS}

Tabela 1 - Distribuição de fases do DNAPL no subsolo...... 38

Tabela 2 - Exemplos de casos de ocorrência de poços de produção público que foram impactados por contaminações de compostos organoclorados. 43

Tabela 3 - Cargas e tendências de direção de fluxo das zonas isoladas. 73

Tabela 4 - Intervalos de medição do nível d' água 75

Tabela 5 - Parâmetros hidráulicos do aqüífero. .77

Tabela 6 - Correlação de atividades industriais e potencial de geração de carga contaminante. 84

Tabela 7 - Propriedades dos EEC e EAC. 89

Tabela 8 - Utilização, tipo de exposição e efeitos no ser humano. 90

Tabela 9 - Valores máximos e médios de composto em Áreas Declaradas Contaminadas...... 94

Tabela 10 - Ocorrências e Concentrações de EEC e EAC em poços $(\mu \mathrm{g} / \mathrm{L})$........................... 98

Tabela 11 - Poços com EEC ou EAC $(\mu \mathrm{g} / \mathrm{L})$.................................................................... 99

Tabela 12- Medidas de restrição e controle para os poços de produção. ...............................112 


\section{LISTA DE MAPAS}

Mapa 1 - Geologia da área de estudos.

30

Mapa 2 - Cruzamento de informações sobre as atividades com carga potencial de contaminação e os índices de vulnerabilidade natural dos aqüíferos.

Mapa 3 - Elementos de interesse e Áreas de Restrição e Controle de Uso de Água

Subterrânea 110 


\section{LISTA DE SIGLAS}

BAT: Bacia do Alto Tietê

CETESB: Companhia de Tecnologia de Saneamento Ambiental

CMSP: Câmara Municipal de São Paulo

COVISA: Coordenação de Vigilância e Saúde

CPI: Comissão Parlamentar de Inquérito

CRH: Conselho Estadual de Recursos Hídricos.

CTAS: Câmara Técnica de Água Subterrânea

CVS: Centro de Vigilância Sanitária

DAEE: Departamento de Águas e Energia Elétrica

DNPM: Departamento Nacional de Produção Mineral.

EMPLASA: Empresa Paulista de Planejamento Metropolitano S.A.

EUA: Estados Unidos da América.

FEHIDRO: Fundo Estadual de Recursos Hídricos.

FUSP: Fundação de Apoio à Universidade de São Paulo.

IAC: Instituto Agronômico.

IG: Instituto Geológico .

IG-USP: Instituto de Geociências da Universidade de São Paulo.

IPT: Instituto de Pesquisas Tecnológicas.

GSA: Departamento de Geologia Sedimentar e Ambiental.

PMSP: PREFEITURA Municipal de São Paulo.

RMSP: Região Metropolitana de São Paulo.

SABESP: Companhia de Saneamento Básico do Estado de São Paulo.

SEADE: Fundação Sistema Estadual de Análise de Dados.

SES: Secretaria de Estado de Saúde.

SSE: Secretaria de Saneamento e Energia.

SERHS: Secretaria de Recursos Hídricos e Saneamento.

SMA: Secretaria do Meio Ambiente.

SIGRH - Sistema Integrado de Gerenciamento de Recursos Hídricos de São Paulo.

SIPOL: Sistema de Fontes de Poluição.

SVMA: Secretaria do Verde e do Meio Ambiente.

USP: Universidade de São Paulo.

UGRHI: Unidade de Gerenciamento de Recursos Hídricos.

USEPA: United States Environmental Protection Agency.

USGS: United States Geological Services. 


\section{LISTA DE ABREVIAÇÕES}

ACD: Áreas Contaminadas Declaradas.

AEPC: Atividades com Elevado Potencial de Contaminação.

ARC: Área de Restrição e Controle.

BTXE: Benzeno, Tolueno, Xilenos e Etilbenzeno.

CV: Cloreto de Vinila.

DCA: Dicloroetano.

DCE: Dicloroeteno.

DNAPL: Dense Nonaqueous Phase Liquids.

EAC: Etanos clorados.

EEC: Etenos clorados.

ETE: Estação de Tratamento de Efluentes.

GOD: Groundwater hydraulic confinement, Overlaying Strata, Depth to groundwater table.

PCE: Percloroetileno.

POSH: Pollutant Origin Surcharge Hydraulically.

SIG: Sistema de Informação Geográfica.

TCA: Tricloroetano.

TCE: Tricloroeteno.

VMP: Valor Máximo Permitido.

VOI: Valores Orientadores de Intervenção.

VOC: Compostos Orgânicos Voláteis. 


\section{INTRODUÇÃo}

A região do canal Jurubatuba apresenta uma contaminação de água subterrânea por solventes organoclorados alifáticos, nas zonas de maior ocupação industrial, proveniente de várias fontes, que alcançou a rede de poços de produção, expondo a população a riscos.

Esta situação levou a Companhia de Tecnologia de Saneamento Ambiental (CETESB) e a Coordenação de Vigilância em Saúde (COVISA) a atuarem conjuntamente, intensificando investigações ambientais e lacrando poços. Em seguida, o Departamento de Águas e Energia Elétrica (DAEE), órgão estadual gestor dos recursos hídricos, determinou uma "Área de Restrição e Controle Temporário" de uso da água, evidenciando um certo conflito pelo uso da água subterrânea.

A Câmara Técnica de Águas Subterrâneas do Conselho Estadual de Recursos Hídricos CTAS-CRH priorizou seis áreas no Estado para a "definição de áreas de restrição e controle da captação e uso das águas subterrâneas", entre elas a do Jurubatuba. Com verba do Fundo Estadual de Recursos Hídricos (FEHIDRO) o DAEE contratou a empresa Servmar Serviços Técnicos Ambientais para definir tecnicamente as medidas de restrição e controle de uso da água subterrânea.

Utilizando-se da infra-estrutura dedicada ao projeto contratado pelo Estado, através do DAEE, com a empresa Servmar, e por estar à frente da coordenação de execução do projeto na empresa, houve a oportunidade de integrar estudos acadêmicos de modo a contribuir tanto no escopo e execução, quanto na transposição para uma linguagem acadêmica com a descrição do projeto-piloto na dissertação de mestrado. O projeto da Servmar com o DAEE (Servmar, 2008; Servmar, 2009) será referido nesta dissertação como projeto DAEE-Servmar.

Este trabalho deve, portanto, contribuir no cumprimento das recomendações de Rocha et al (1989), quanto a "realizar análises de quantidade e qualidade das águas, com vistas ao gerenciamento integrado dos recursos hídricos; e buscar uma efetiva coordenação das ações dos organismos governamentais, institutos de pesquisas e empresas, de modo a superar a atuação isolada que hoje predomina". 


\section{OBJETIVOS}

O objetivo deste trabalho é reconhecer o cenário de contaminação regional por solventes organoclorados alifáticos na região do entorno do canal Jurubatuba e apresentar uma metodologia para a delimitação de áreas de restrição e controle de uso da água subterrânea para o local.

Para tanto, deve-se cumprir os seguintes objetivos específicos:

- o reconhecimento e a apresentação do histórico do caso;

- o levantamento e a análise da aplicação das legislações federal, estadual e municipal;

- o reconhecimento das características de uso e ocupação do solo;

- o levantamento, o tratamento, a complementação e a interpretação de dados preexistentes;

- o entendimento e a apresentação de modelos conceituais geológicos e hidrogeológicos;

- o entendimento da qualidade da água subterrânea impactada;

- e a própria definição de medidas de restrição e controle de uso de água subterrânea.

A importância deste estudo está na oportunidade de descrever uma metodologia para a delimitação de uma Área de Restrição e Controle de uso das águas subterrâneas numa região com um dos mais expressivos casos de contaminação do país, elaborada sob a motivação de redefinir, com embasamento técnico, o traçado determinado na Portaria ํㅜㅅ.594 do DAEE.

Considerando o quadro regional de contaminação existente na área, estabelecer estas áreas de restrição e medidas de controle de uso das águas subterrâneas é um desafio para proteger a saúde pública, recuperar melhores condições de qualidade do aqüífero e minimizar a continuidade de espalhamento de contaminantes. 


\section{3 ÁREA DE ESTUDO}

\subsection{Localização}

A área de estudos possui $120 \mathrm{~km}^{2}$ e está localizada nas zonas centro-sul e sul do município de São Paulo (Figura 1), entre as coordenadas 7376 e $7388 \mathrm{~km}$ de latitude e 320 e $330 \mathrm{~km}$ de longitude. $\mathrm{O}$ acesso à área pode ser feito pela Avenida das Nações Unidas (Marginal de Pinheiros), que por sua vez conecta-se à Marginal do Tietê e a diversas rodovias que seguem para o interior do Estado. A partir do litoral a área é acessada pela Rodovia dos Imigrantes seguindo pela Avenida dos Bandeirantes. Os distritos do município que estão integralmente inseridos na área de estudos são: Campo Grande, Jardim São Luis, Santo Amaro, Socorro e Vila Andrade. A área abrange ainda, a noroeste, um pequeno trecho do município de Taboão da Serra, mas que não teve significado relevante ao tema do trabalho.

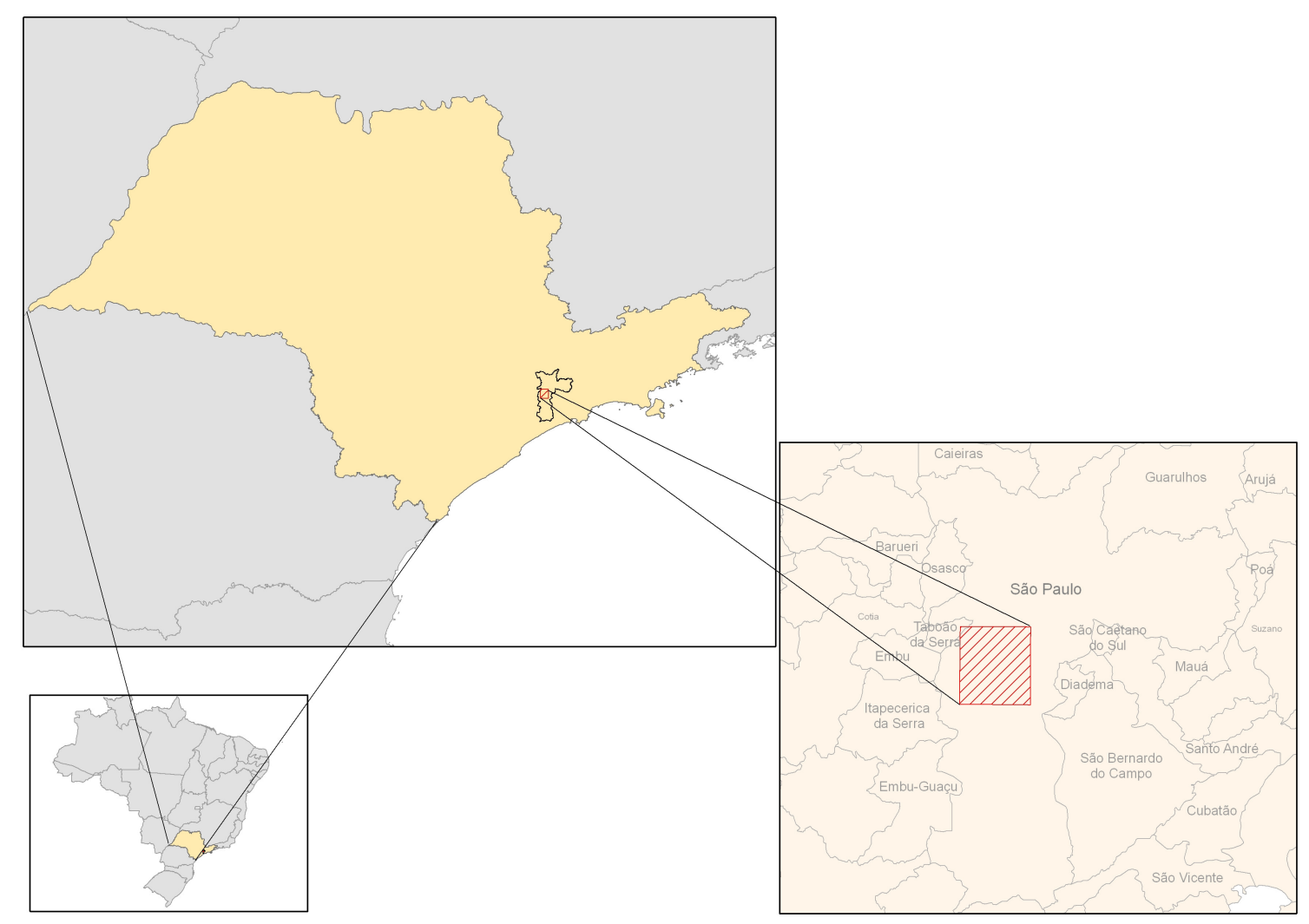

Figura 1 - Localização da área de estudo. 


\subsection{Contexto Histórico}

Para a descrição do contexto histórico local foram utilizadas, principalmente, as apresentações do Departamento de Águas e Energia Elétrica (DAEE), da Companhia de Tecnologia de Saneamento Ambiental (CETESB), da Vigilância em Serviços de Saúde (COVISA) e da Prefeitura Municipal de São Paulo (PMSP), realizadas e disponibilizadas em diversos eventos relacionados ao caso em estudo.

Segundo a CETESB, em novembro de 2001, a empresa Gillette a comunicou sobre os resultados de uma investigação confirmatória com detecção de solventes halogenados alifáticos no solo e na água subterrânea. A CETESB autuou a Gillette impondo investigações adicionais e a implantação de um sistema de remediação. A empresa autuada apontou, nos referidos estudos, que a contaminação teve origem com a empresa Duracell, entre 1981 e 1993.

Em 2002 e 2003, a empresa autuada constatou que a contaminação havia atingido o aqüífero Cristalino. Identificou-se 14 poços profundos licenciados pelo DAEE, dos quais três estavam a jusante das plumas de contaminação. Estes três poços destinavam-se ao abastecimento privado de água do Shopping SP Market. Em dezembro de 2003 a CETESB realizou uma amostragem nos três poços e foram detectados contaminantes nas três amostras coletadas.

Ainda segundo a CETESB, em janeiro de 2004, ela comunicou os resultados das análises químicas ao Centro de Vigilância Sanitária Estadual (CVS), recomendando o fechamento de um dos poços, no qual os contaminantes estavam acima dos valores de referência da Portaria 518 e o monitoramento mensal dos demais, que também deveriam ser interditados caso fossem observadas concentrações superiores às estabelecidas pela Portaria.

A partir de 2005, o controle da exploração de poços cadastrados no DAEE passou a ter um acompanhamento conjunto entre o DAEE e a COVISA, quanto ao monitoramento de análises químicas dos poços, tendo sido exigidas análises periódicas que englobassem os solventes halogenados alifáticos.

A CETESB ampliou a coleta de amostras e análise química em 07 poços de produção, apontou contaminação nos poços e refoçou as suspeitas da existência de contaminação na água subterrânea profunda da região, possivelmente originada em mais de uma fonte.

Segundo a CETESB, iniciou-se um processo de identificação de outras fontes potenciais e suspeitas de contaminação, com a finalidade de exigir a investigação destas áreas e ampliar o diagnóstico ambiental da região do entorno da empresa autuada. A CETESB informou terem sido inspecionadas 48 áreas e coletadas amostras em 26 poços profundos. Assim, a CETESB 
afirma, baseando-se principalmente no levantamento da qualidade da água dos poços profundos, que a contaminação não tem origem somente na área da empresa Gillette.

A partir de junho de 2005, a CETESB emitiu ofícios para a COVISA informando a ocorrência de solventes halogenados alifáticos em poços profundos nas adjacências da empresa Gillette. A COVISA interditou esses poços e emitiu um ofício para a CETESB relatando a interdição e solicitando ao DAEE, a não concessão de outorgas na área, até que se conhecesse a extensão da contaminação. A Figura 2 ilustra a localização e a data de interdição de 43 poços no $2^{\circ}$. semestre de 2005.

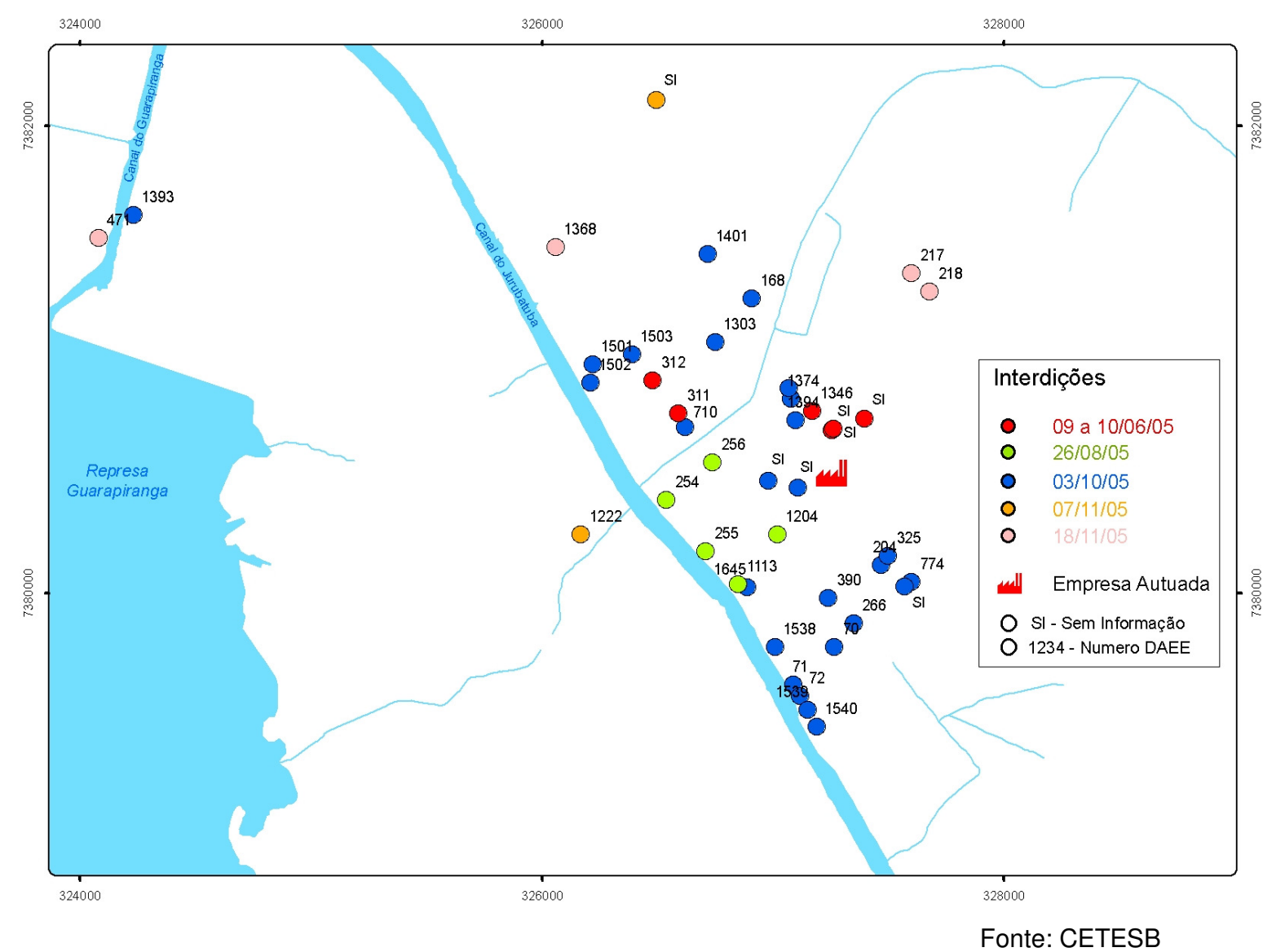

Figura 2 - Histórico de poços interditados.

Em agosto de 2005, o caso de contaminação apareceu na mídia, publicado pelos dois principais jornais paulistas.

Para o gerenciamento regional do problema, o DAEE baixou a Portaria DAEE no 1594, de 05 de Outubro de 2005 e criou uma "Área de Restrição e Controle Temporário" da água subterrânea.

Em abril de 2005, o Conselho Estadual de Recursos Hídricos (CRH) instituiu, no âmbito do Sistema Integrado de Gerenciamento de Recursos Hídricos (SIGRH), diretrizes e procedimentos para a definição de áreas de restrição e controle da captação e uso das águas 
subterrâneas (Deliberação no 52). O art. 1ํe estabelece que "Áreas de Restrição e Controle do uso das águas subterrâneas são aquelas onde existe a necessidade de disciplinar as atividades que possam causar alterações ou efeitos negativos sobre a quantidade ou qualidade das águas subterrâneas".

Em fevereiro de 2006, a Câmara Municipal de São Paulo (CMSP) instaurou uma Comissão Parlamentar de Inquérito (CPI), para apurar responsabilidades pela poluição sonora, atmosférica, da água e do solo, além dos passivos ambientais, no âmbito do Município de São Paulo. Neste documento foram abordadas as atribuições do DAEE, do Departamento Nacional de Produção Mineral (DNPM) e da COVISA, bem como as contaminações das empresas Gillette e Novartis, além de consideradas as possíveis incidências da contaminação da Novartis sobre as águas minerais Cristalina e Petrópolis Paulista.

Em junho de 2006 foi publicada a Resolução no 3 pela Secretaria de Estado do Meio Ambiente, de Energia, Recursos Hídricos e Saneamento, e da Saúde (SES/SERHS/SMA), que dispõe sobre procedimentos integrados para controle e vigilância de soluções alternativas coletivas de abastecimento de água para consumo humano proveniente de mananciais subterrâneos, compatibilizando as autorizações, licenças ambientais e o cadastro e monitoramento com as outorgas de recursos hídricos subterrâneos. As áreas de restrição e controle estabelecidas pelo $\mathrm{CRH}$, as Áreas Contaminadas Declaradas (ACD) pela CETESB e as fontes pontuais com potencial de contaminação do solo e das águas subterrâneas, segundo a resolução, deverão ser consideradas como condicionantes para análise e emissão de outorga.

Visando dar maior sustentação técnica à aplicação de restrição de uso de água subterrânea na região, para substituir a "Área de Restrição e Controle Temporário" da Portaria DAEE n 1594, o DAEE publicou, em 2006, um edital para a execução do projeto "Delimitação de Áreas de Restrição e Controle de Captação e Uso de Águas Subterrâneas no município de São Paulo". A empresa Servmar Serviços Técnicos Ambientais apresentou proposta e foi habilitada para executar o projeto.

\subsection{Características do Meio Físico}

\subsubsection{Hidrografia, geomorfologia e clima}

A área é cortada ao centro pelos canais do Jurubatuba e Guarapiranga e pelo rio Pinheiros. O canal do Jurubatuba liga o rio Pinheiros à represa Billings e o canal da Guarapiranga liga o rio Pinheiros à represa Guarapiranga. 
As principais drenagens são o rio Pinheiros, os canais do Jurubatuba e da Guarapiranga, os córregos Águas Espraiadas, Maria Joaquina, Cachoeirinha, Pedreiras e Piraporinha e os ribeirões Morro do S e Guavirituba. A área está inserida nas Sub-Bacias Penha-Pinheiros, Cotia-Guarapiranga e Billings, na Bacia do Alto Tietê, Unidade de Gerenciamento de Recursos Hídricos (UGRHI) 6.

O relevo é plano no setor leste e um pouco acidentado no setor oeste, devido a ocorrência, em superfície, de rochas sedimentares e cristalinas, respectivamente. As cotas topográficas vão de 743 m (Cidade Dutra) a 853 m (Região de Vila Andrade). A área estudada encontra-se no Planalto Atlântico. Conforme Rocha (2005), a topografia do Planalto Atlântico, apresenta as mais variadas feições, tais como planícies aluviais (várzeas), colinas, morros, serras e maciços com variadas orientações.

O Oceano Atlântico encontra-se a $50 \mathrm{~km}$ da área de estudo. Esse quadro físico define um conjunto de controles climáticos. A temperatura média anual observada na estação do Instituto Agronômico (IAC), próxima à área de estudos, entre 1992 e 2007, foi de 21,2드 (PMSP, 2002).

Dados da estação pluviométrica do DAEE (E3-006), obtidos entre 1936 e 2002 (SIGRH, 2007), apontaram que a precipitação média anual foi de $1.304 \mathrm{~mm}$. Os índices pluviométricos totais mensais variaram entre o mínimo de 0,0 mm (agosto de 1944/78 e junho de 1986) e o máximo de $441 \mathrm{~mm}$ no período mais chuvoso (março de 1991).

\subsubsection{Uso e ocupação do solo}

A área de estudos apresenta uma ocupação mista: industrial, comercial e residencial. Ocorre um adensamento da ocupação industrial ao longo dos canais do Jurubatuba e Guarapiranga e do rio Pinheiros.

Foram verificados os diferentes usos e ocupação do solo na região (Figura 3), mapeados pela Empresa Paulista de Planejamento Metropolitano S.A. (EMPLASA), a partir do qual veio a ser definida a base cartográfica utilizada neste projeto, constituída de hidrografia e ocupação industrial. A região de estudos é densamente urbanizada e contém preservadas poucas áreas de mata e campo. O principal uso do solo que afeta a qualidade da água é o industrial.

Conforme Vrba (2001), o perigo de centros industriais em áreas urbanas vem de produtos químicos tóxicos suficientemente solúveis, móveis e persistentes para atingir poços. Os solventes halogenados, compostos de interesse neste trabalho, possuem estas características.

A população dos distritos localizados na área de estudo chegou a 2.364.305 de habitantes em 2004 (SEADE). Porém, pelo fato de muitos desses distritos estarem apenas 
parcialmente na área de estudos, a população da área deve ser pouco menor do que 2 milhões de habitantes. O bairro Campo Grande, na porção leste, é o mais populoso dentre os inteiramente contidos na área de estudos, como uma população de 932.960 habitantes.

Segundo a PMSP (2002), nas décadas de 50 e 60, o Estado de São Paulo viveu intenso processo de expansão industrial. Dentre os distritos que estão completamente inseridos na área de estudos, o desenvolvimento industrial teve grande influência em Socorro, Campo Grande e Santo Amaro. Esses distritos, a exemplo de outras regiões de São Paulo, tiveram parte de suas indústrias, a partir de 1996, transferidas para o interior do Estado e, por conseguinte, o desenvolvimento de um setor de comércios e de serviços (PMSP, 2007).

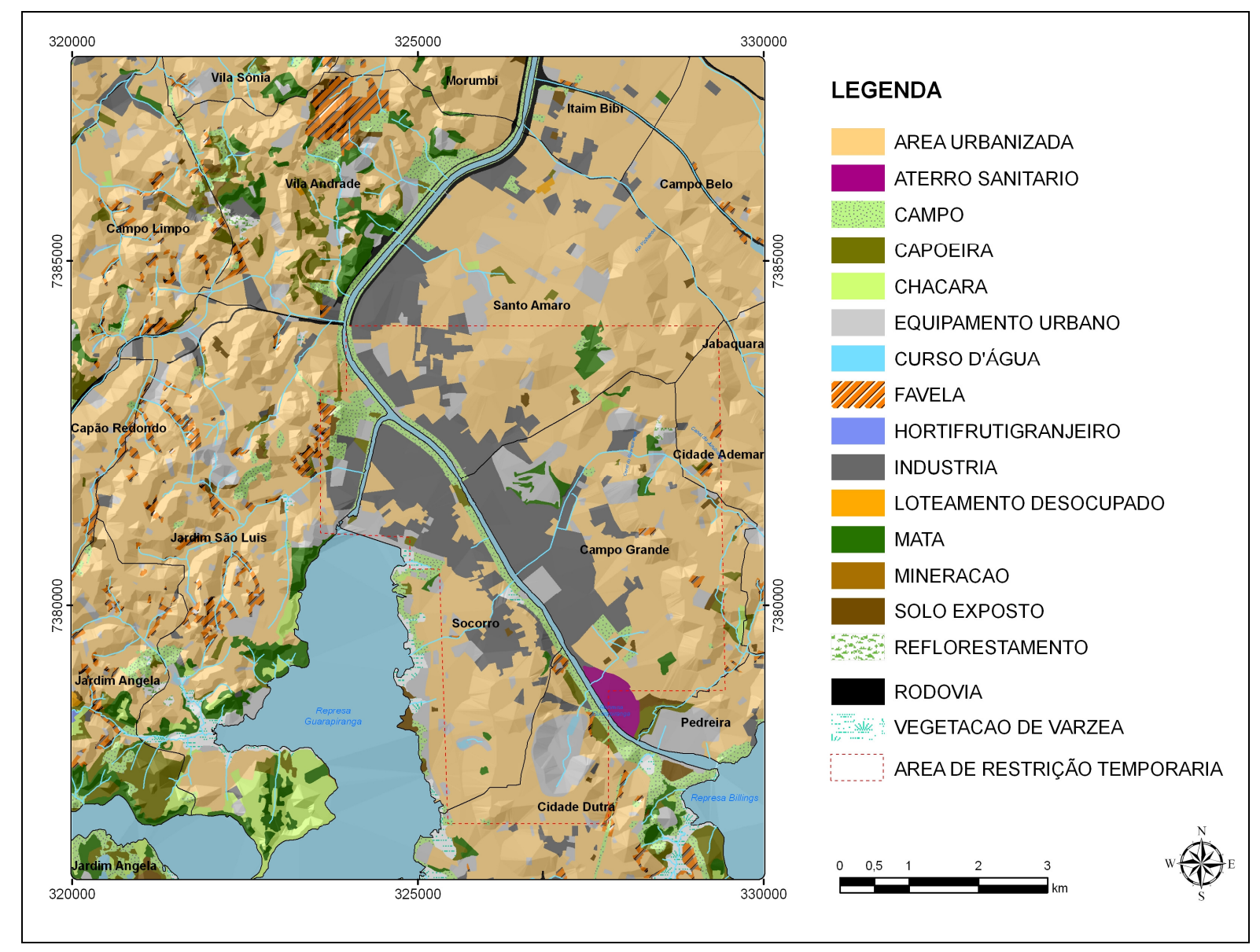

Fonte: Emplasa (2005)

Figura 3 - Uso e ocupação do solo.

O Plano da Bacia do Alto Tietê (FUSP, 2002) indica evidências de queda acentuada do uso de água na atividade industrial do Município, atribuídas à diminuição da atividade e à saída dos usuários da rede de abastecimento. Usuários comerciais também vêm optando por abandonar a rede de distribuição substituindo-a por poços de água subterrânea (FUSP, 2002). 
Concomitantemente à diminuição das indústrias, observa-se um acréscimo da ocupação residencial, principalmente por condomínios verticais, de classe social média-alta, na região estudada. Essas mudanças foram observadas em trabalhos de campo e comparações de fotos aéreas antigas e imagens atuais (Figura 4).

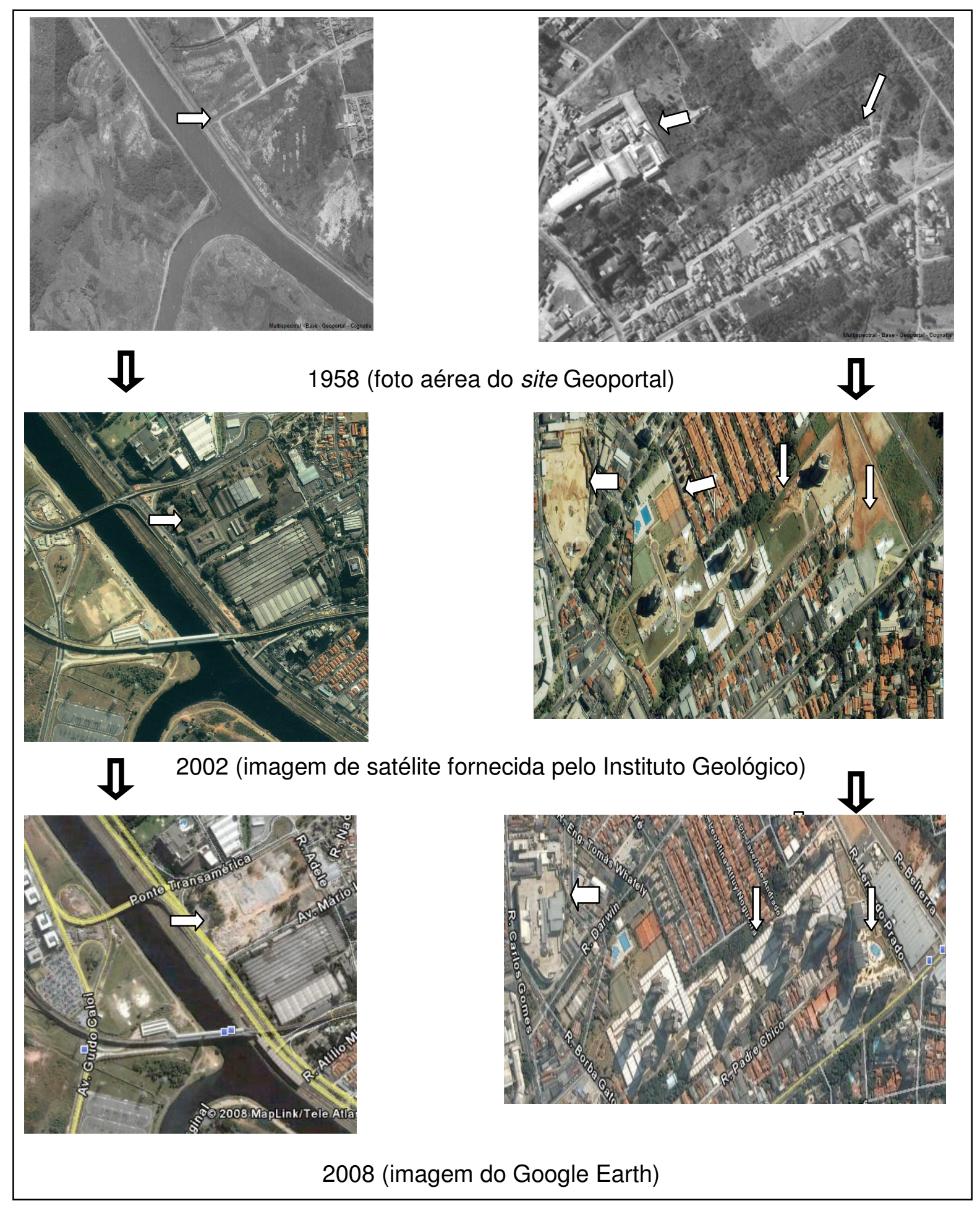

Figura 4 - Mudança de uso e ocupação do solo. Evolução da concentração de indústrias e posterior instalação de novos empreendimentos e condomínios verticais. 


\subsubsection{Infra-Estrutura Sanitária}

O abastecimento de água no município de São Paulo e a rede de coleta de esgoto são realizados pela Companhia de Saneamento Básico do Estado de São Paulo (SABESP), ligada à Secretaria de Saneamento e Energia (SSE).

O abastecimento por águas superficiais no Município de São Paulo depende de quatro sistemas produtores: Cantareira, Guarapiranga, Alto Tietê e Rio Claro. Atualmente, a produção desses quatro sistemas é de $61 \mathrm{~m} /{ }^{3} \mathrm{~s}$, com déficit de $13 \mathrm{~m}^{3} / \mathrm{s}$ (DAEE, 2007). Na região de estudos, o abastecimento se dá pelo sistema Guarapiranga, com disponibilização total de 10 $\mathrm{m}^{3} / \mathrm{s}$ (FUSP, 2002).

Embora a região seja atendida pela SABESP com a rede de distribuição de água e rede de coleta de esgoto (Figura 5), a rede de distribuição de água não supriria toda a demanda doméstica e industrial somadas e a rede de coleta de esgoto não abrange justamente a área crítica de ocupação industrial.

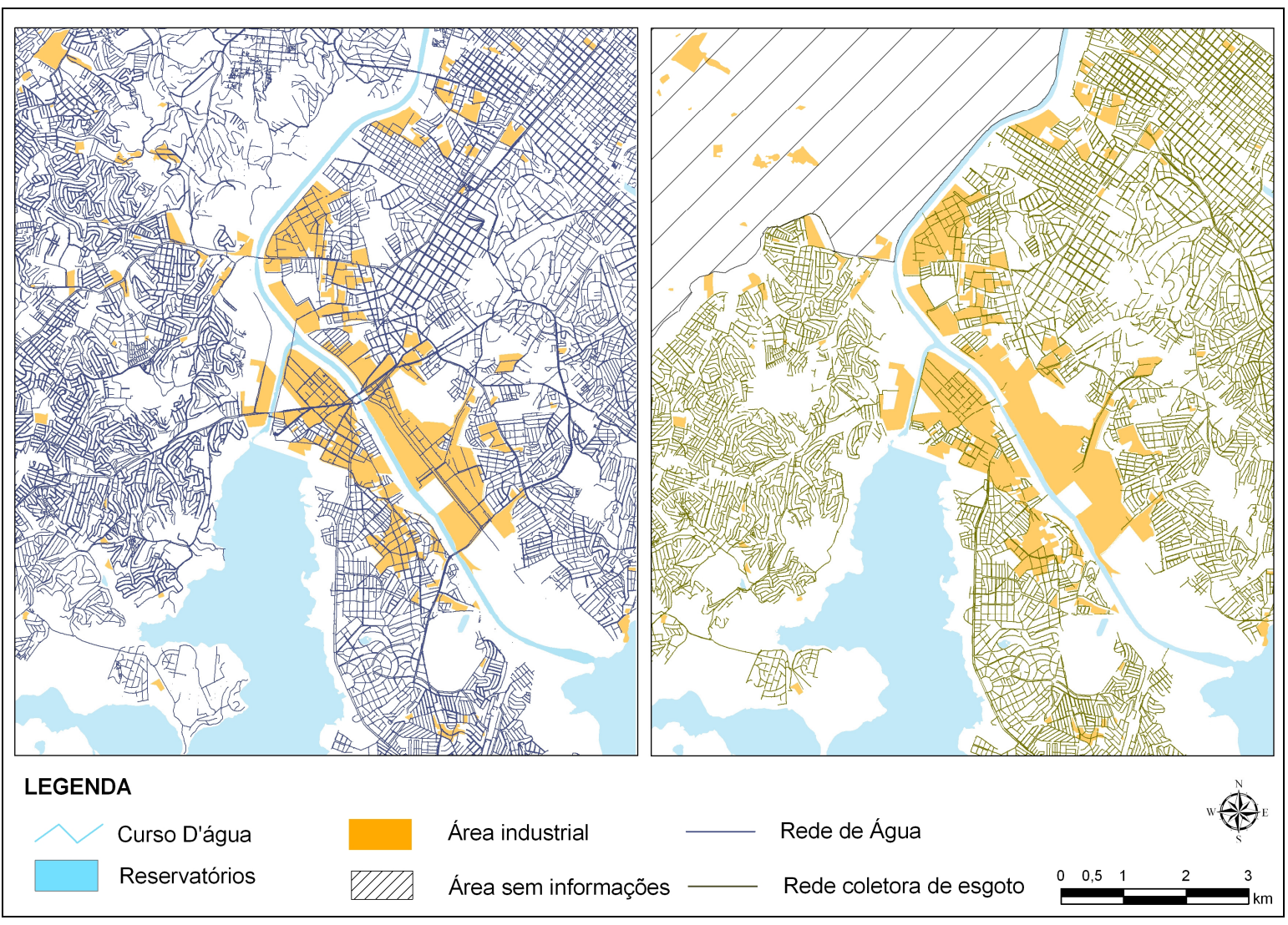

Fonte: SABESP

Figura 5 - Redes de distribuição de água e coleta de esgoto. 
Embora o sistema produtor de águas superficiais seja o maior para o município de São Paulo, estima-se que sejam explorados mais de 315 milhões de $\mathrm{m}^{3}$ de águas subterrâneas por ano, resultado de bombeamento de cerca de 9 mil poços em operação (Hirata e Ferreira, 2001). Somente cerca de $30 \%$ deste total estariam cadastrados no DAEE (FUSP, 2002).

A cobertura da rede de abastecimento de água abrange a maioria dos domicílios do município, com algumas exceções em favelas e loteamentos irregulares (PMSP, 2002).

A rede de coleta de esgoto, de acordo com o Plano da BAT (FUSP, 2002), é realizada em todos os distritos da região e o esgoto é enviado para a Estação de Tratamento de Esgoto ETE de Barueri.

\subsection{Geologia}

A Região Metropolitana de São Paulo (RMSP) encontra-se desenvolvida sobre terrenos sedimentares de idade cenozóica da Bacia Sedimentar de São Paulo, que é hoje entendida como uma das unidades integrantes do denominado Rift Continental do Sudeste do Brasil (Riccomini, 1989).

A origem atualmente admitida para rift está relacionada às inúmeras falhas menores normais, inversas e de empurrão associadas e à reativação normal de antigas zonas de cisalhamento do embasamento Terciário (Eoceno-Oligoceno), denominadas de Faixa de Cisalhamento de São Paulo por Hasui et al (1984).

Segundo Riccomini; Coimbra; Takiya (1992), a borda norte da Bacia de São Paulo é retilínea, controlada pela zona de cisalhamento Taxaquara-Jaguari, enquanto que ao sul, os contatos com o embasamento cristalino são irregulares. Conforme Juliani (1992) a bacia é considerada um hemi-graben, basculado para NNW, desenvolvido sobre Terrenos Cristalinos Pré-Cambrianos representados por granitos sin e pós-tectônicos e por rochas metamórficas (migmatitos, gnaisses, xistos e metassedimentos em geral), relacionados ao Complexo Embu e aos grupos São Roque e Serra do Itabereba.

Conforme Rocha et al (1989), a topografia do substrato cristalino apresenta-se acidentada na forma de horts e grabens, originando sub-bacias, janelas e ramificações laterais. A altitude média das colinas e espigões esculpidos nos sedimentos está ao redor de $760 \mathrm{~m}$, atingindo $840 \mathrm{~m}$ no alto do Sumaré e Paulista e $719 \mathrm{~m}$ na várzea do rio Tietê.

Conforme proposto por Riccomini; Coimbra; Takiya (1992), a estratigrafia da Bacia de São Paulo está relacionada ao Grupo Taubaté (Paleógeno), constituído da base para o topo, pelas Formações Resende, Tremembé e São Paulo; recoberto, pela Formação 
Itaquaquecetuba (Neógeno) e coberturas aluvionares fluviais do Quaternário (Qa). Segundo Takyia (1991), a espessura média dos sedimentos da bacia é da ordem de $100 \mathrm{~m}$ e, em algumas áreas, chegam a atingir mais de $250 \mathrm{~m}$.

$\mathrm{Na}$ área de estudos (Figura 6) a porção de rochas graníticas aflora a noroeste da área (PCgo) e bem distribuídos na área (PCg). O Grupo Açungui, composto pelo Complexo Embu e Complexo Pilar, que constitui a mais extensa unidade do Pré-Cambriano Paulista, atravessa todo o Estado de São Paulo em sua porção E-SE. Destacam-se ainda os micaxistos (PCx), conjunto litológico de grande expressão na área. A norte, o Grupo São Roque pode ser identificado por ocorrências locais de quartzitos (PCq) e anfibolitos (PCa).

A Bacia Sedimentar de São Paulo aflora a leste da área, predominando as duas litofácies da Formação Resende, ao norte (Orf) e a leste e sul (Orl), da área de estudos. A Formação São Paulo (Osp) ocorre numa porção restrita, no extremo leste da área. Ao longo do rio Pinheiros e Canais do Jurubatuba e Guarapiranga afloram coberturas aluvionares fluviais do Quaternário $(\mathrm{Qa})$. As Formações Tremembé e Formação Itaquaquecetuba não afloram na região de estudos. 


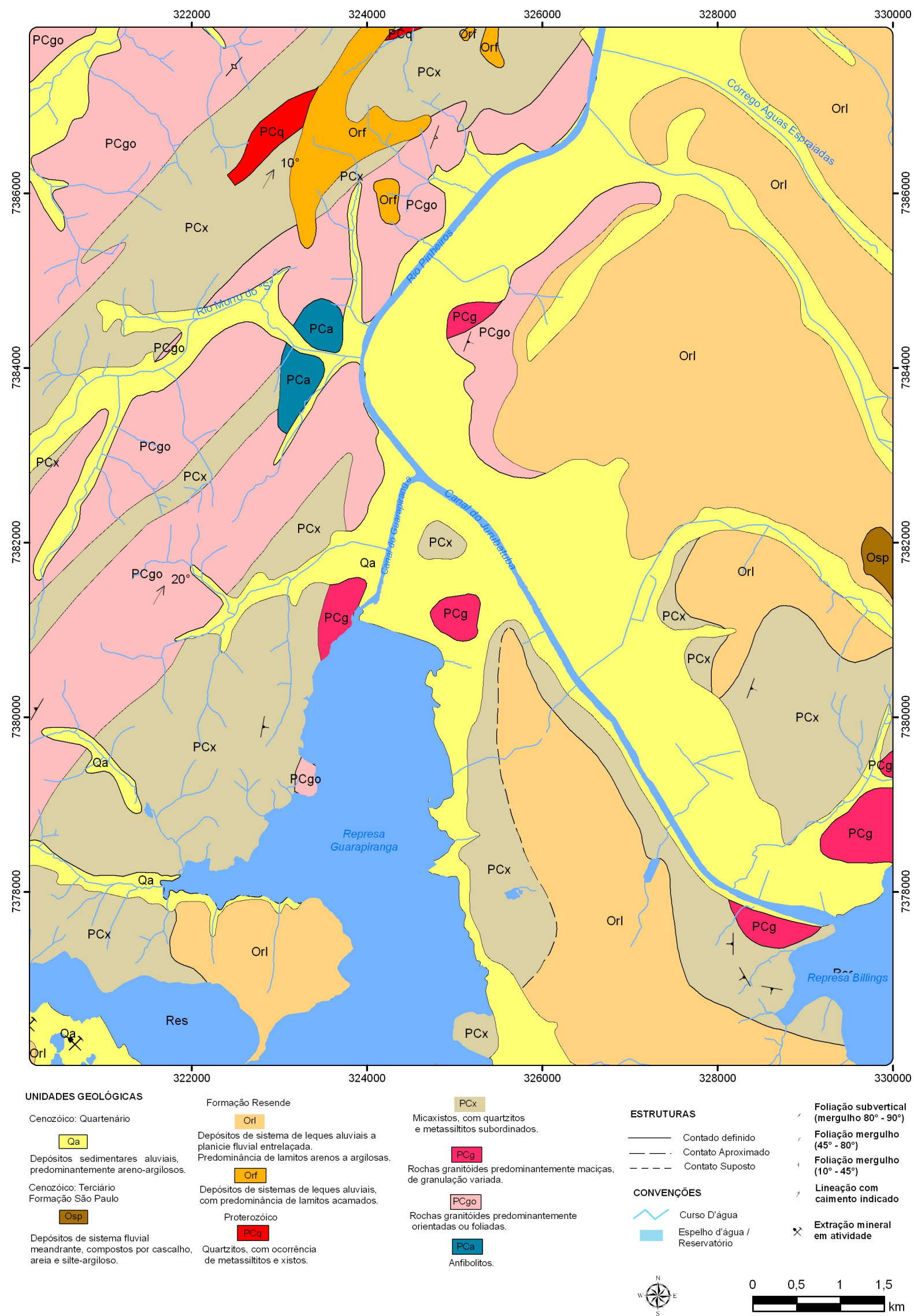

Fonte: FUSP (2002)

Mapa 1 - Geologia da área de estudos. 


\subsection{Hidrogeologia}

Na Bacia do Alto Tietê (BAT) ocorrem basicamente dois sistemas aqüíferos: o Cristalino e o Sedimentar. O aqüífero Sedimentar, de porosidade primária, subdivide-se em aqüíferos Quaternário, São Paulo e Resende. Já o aqüífero Cristalino, de porosidade secundária, subdivide-se em aqüíferos A e B (FUSP, 2002) Figura 6.

O aqüífero cristalino caracteriza-se por aqüífero livre a semiconfinado. Ocorre nos domínios das rochas cristalinas do embasamento, do Éon Proterozóico. Estas rochas afloram na porção oeste da área e correspondem à associação de unidades que incluem rochas granitóides. O aqüífero sedimentar, de idade Terciária, é constituído pelas formações São Paulo e Resende e ainda sobreposto por sedimentos do aqüífero Quaternário.

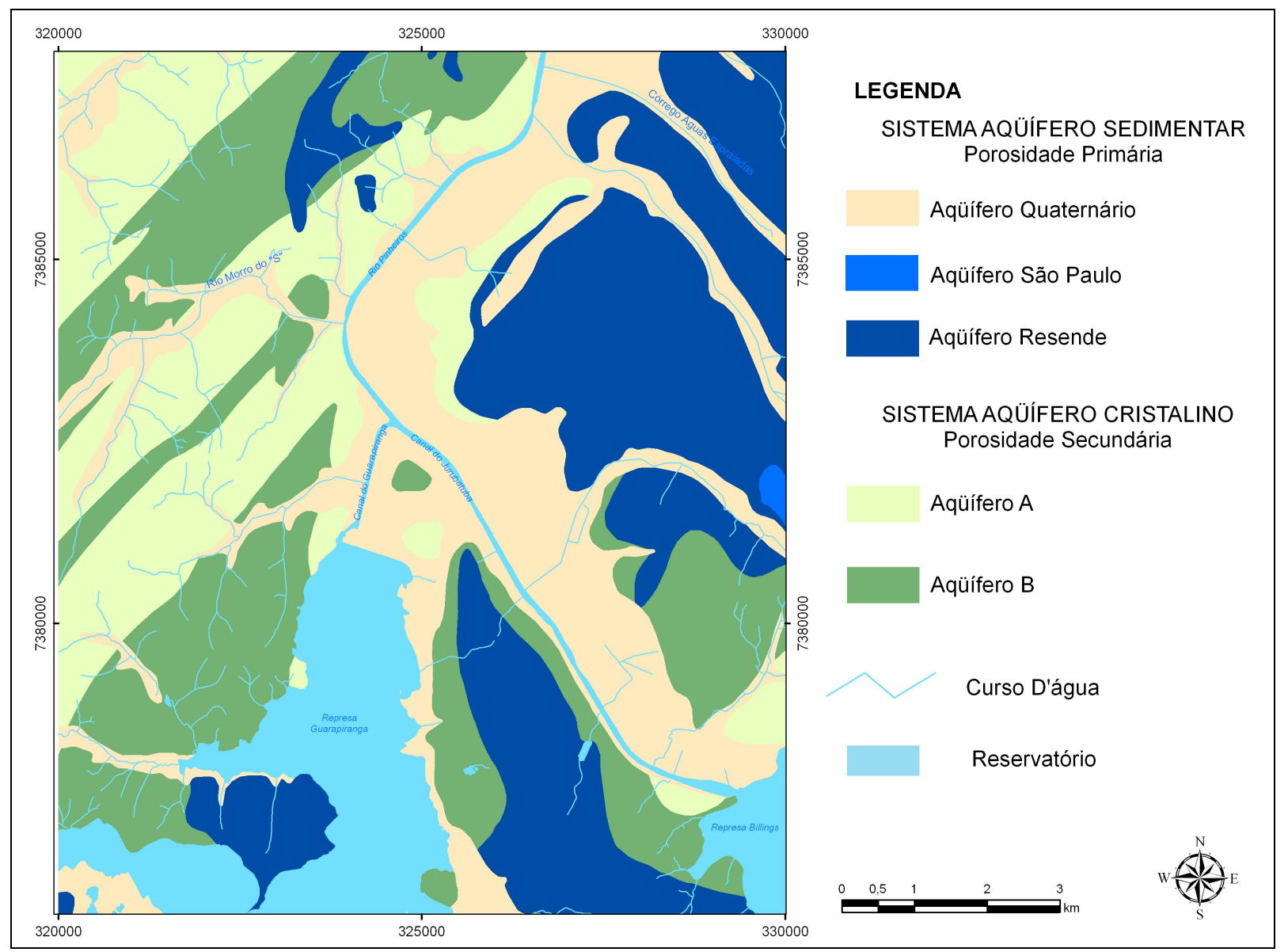

Fonte: FUSP (2002)

Figura 6 - Hidrogeologia da área de estudos.

O aqüífero Quaternário (Qa) engloba depósitos sedimentares aluviais, predominantemente areno-argilosos. Apresenta espessura métrica e é explorável através de poços cacimba. 
O aqüífero São Paulo (Osp) corresponde a depósitos de sistema fluvial meandrante, compostos por cascalho, areia e silte argiloso. Caracteriza-se como aqüífero livre a semiconfinado, de extensão local e baixa produtividade. Vazão média individual por poço de $9,5 \mathrm{~m}^{3} / \mathrm{h}$ e capacidade específica de $0,5 \mathrm{~m}^{3} / \mathrm{h} / \mathrm{m}$.

O aqüífero Resende corresponde a depósitos de sistema de leques aluviais a planície fluvial entrelaçada com predominância de lamitos arenosos e argilosos (Orl) e depósitos de sistemas de leques aluviais, com predominância de lamitos seixosos (Orf). Caracteriza-se por aqüífero livre a semiconfinado, de extensão local e média a baixa produtividade. Vazão média individual por poço de $15,2 \mathrm{~m}^{3} / \mathrm{h}$ e capacidade específica de $0,9 \mathrm{~m} 3 / \mathrm{h} / \mathrm{m}$.

$\mathrm{Na}$ área de estudos, o aqüífero Resende aflora a leste da área, predominando sobre o aqüífero São Paulo, que ocorre numa porção restrita e os depósitos do Quaternário, que ocorrem ao longo do rio Pinheiros e canais do Jurubatuba e Guarapiranga. Na porção oeste da área aflora o aqüífero Cristalino.

DAEE; IG-SMA; IPT; CPRM (2005), denomina Aqüífero São Paulo todo o pacote sedimentar referido nesta dissertação como aqüífero Sedimentar. De acordo com DAEE; IGSMA; IPT; CPRM (2005), o aqüífero São Paulo é constituído por sedimentos que preenchem a Bacia de São Paulo. Estes sedimentos ocupam uma área com pouco mais de $1.000 \mathrm{~km}^{2}$, e estão distribuídos irregularmente na porção central da bacia hidrográfica do alto do curso do rio Tietê, coincidindo aproximadamente com a área ocupada pelo município de São Paulo e arredores, cuja população é da ordem de 13 milhões de habitantes. Este aqüífero ocupa uma área aproximada de $25 \%$ da Bacia do Alto Tietê (Bertolo 1996), é o mais importante por ser o mais explorado e por abrigar a maior parte da metrópole. A altitude média das colinas sedimentares situa-se ao redor da cota 760 metros, atingindo um máximo de $840 \mathrm{~m}$ no espigão da avenida Paulista e um mínimo de 710 metros na soleira de Barueri, onde o sistema encontra-se hidraulicamente fechado. Suas condições de ocorrência de água subterrânea são de aqüífero semiconfinado, heterogêneo e anisotrópico. Dados obtidos da rede de poços monitorados no aqüífero estudado por Hirata e Ferreira (2001) indicam vazões médias de 9,51 $\mathrm{m}^{3} / \mathrm{h}$ para Formação São Paulo, e 15,24 m³/h para a Formação Resende.

O aqüífero Cristalino é constituído por rochas pré-cambrianas que correspondem a rochas ígneas e metamórficas e suas altitudes máximas variam entre 800 e 950 metros (Bertolo 1996). Este aqüífero é formado por duas unidades hidrogeológicas características. A primeira unidade (aqüífero A) corresponde ao aqüífero do manto de intemperismo, de natureza livre, heterogêneo e anisotrópico, onde a água circula por porosidade intergranular. A segunda unidade (aqüífero B) corresponde ao aqüífero cristalino propriamente dito, onde a água circula através dos lineamentos estruturais como falhamentos, juntas associadas e fraturas abertas da 
rocha sã, caracterizando o aqüífero como livre a semilivre, heterogêneo e anisotrópico (DAEE, 1975). O potencial de produção de águas subterrâneas nesse aqüífero é geralmente baixo, podendo variar de uma vazão média de $9,07 \mathrm{~m}^{3} / \mathrm{h}$ na porção granitóide a $17,48 \mathrm{~m}^{3} / \mathrm{h}$ no local composto por rochas metassedimentares, segundo Hirata e Ferreira (2001).

$\mathrm{O}$ aqüífero $\mathrm{A}$, do aqüífero Cristalino, corresponde à associação de unidades que incluem rochas granitóides (PCg e PCgo), rochas gnáissicas (PCgn), filitos e xistos subordinados (PCf). Caracteriza-se por aqüífero livre onde as melhores vazões estão associadas às falhas e fraturas nas rochas, com baixa produtividade. Vazão média individual por poço de $9,1 \mathrm{~m}^{3} / \mathrm{h}$ e capacidade específica de $0,2 \mathrm{~m} 3 / \mathrm{h} / \mathrm{m}$.

O aqüífero B corresponde à associação de rochas predominantemente metassedimentares que incluem quartzitos (PCq), micaxistos (PCX), anfibolitos (PCa) e rochas carbonáticas (PCC). Caracteriza-se por aqüífero livre onde as melhores vazões estão associadas às falhas e fraturas nas rochas, com média a baixa produtividade. Vazão média individual por poço de $17,5 \mathrm{~m}^{3} / \mathrm{h}$ e capacidade específica de $1,4 \mathrm{~m} 3 / \mathrm{h} / \mathrm{m}$.

No aqüífero Cristalino é comum encontrar poços próximos com vazões muito diferentes devido à variação no número, tipo, abertura e conexão das fraturas (Rocha, 2005).

Com base em informações, de cadastro dos poços do DAEE, de perfil litológico e construtivo dos poços que exploram a região de estudo, é possível diferenciar os poços que exploram os diferentes aqüíferos (Sedimentar e Cristalino) e os poços que exploram ambos os sistemas (poços mistos). 


\section{REVISÃO BIBLIOGRÁFICA}

A pesquisa bibliográfica focou o entendimento do problema na relação entre solventes organoclorados e a água subterrânea, a partir do conhecimento internacional sobre modelos hidrogeológicos associados ao tema. $\mathrm{O}$ assunto foi encontrado em livros e manuais de agências ambientais, específicos sobre o tema e em estudos de caso. Em seguida, buscou-se compreender atuações de órgãos gestores e a aplicação da legislação brasileira.

\subsection{Uso Sustentável de Água Subterrânea}

Historicamente, Derby (1898) apud Campos (1988), faz menção à proteção dos aqüíferos da Bacia Sedimentar de São Paulo em ofícios ao governo do Estado, referindo-se à água subterrânea "[...] é um suprimento bastante valioso em quantidade que não deve ser desprezado, para o uso particular, uma vez que fosse possível, por meio de um bom regulamento e boa fiscalização de poços, eliminar riscos de contaminação".

Llamas e Martinez (2003) observam que há um crescimento acelerado do uso da água subterrânea impulsionado pelo desenvolvimento de técnicas de bombeamento e de perfuração de poços, pelo baixo custo para obtenção da água e pela falta de aplicação de normas que regulamentam este uso.

A utilização de água subterrânea, no tocante à sustentabilidade de aqǘferos, requer medidas de proteção do aqǘfero e mecanismos de gerenciamento de uso da água. Em relação às medidas de proteção do aqüífero, as principais estão associadas às próprias condições de construção do poço e ao tipo de ocupação do solo nas zonas de contribuição ao aqǘfero. Para o gerenciamento, deve-se conhecer todos os poços existentes, suas características litológicas e construtivas e seus regimes de bombeamentos, bem como operar com monitoramentos de quantidade e qualidade da água subterrânea.

Muitos dos efeitos negativos sob a intensificação do uso da água subterrânea podem levar anos para se tornarem evidentes. Deste modo, há uma tendência em não haver empenho na obtenção de dados de quantidade e qualidade, que requerem um monitoramento regular e periódico. Estes dados de monitoramento são imprescindíveis para o conhecimento sobre a utilização do aqüífero, necessário para apoiar decisões. As informações requeridas para um gerenciamento adequado têm que ser percebidas muito antes dos problemas se materializarem (USGS, 1999). 
A partir de uma perspectiva de manejo, gestores da água, a sociedade e as demais partes interessadas, têm que decidir sobre condições específicas que regulem o uso da água, de maneira a sustentar que não sejam toleradas ações que encaminhem para conseqüências indesejáveis à qualidade ou disponibilidade quantitativa de água (USGS, 1999).

Dentre os impactos sobre os aqüíferos, a serem observados e gerenciados, estão a degradação da qualidade da água, o rebaixamento do nível d'água e impactos ecológicos. Um problema recorrente para a tomada de ações de gerenciamento é a gestão fragmentada entre os órgãos gestores, dificultando ou retardando as atitudes necessárias ao controle e à proteção do aqüífero. Por isso, os parâmetros monitorados devem alimentar uma base única que permita entender eventuais excessos, que alertem para a necessidade de tomada de decisões de manejo integradas. A experiência tem demonstrado que estas ações de manejo devem estar amparadas por legislação.

O uso sustentável da água subterrânea, ou seja, a preservação deste recurso hídrico para as gerações futuras, depende de um bom conhecimento sobre o aqüífero, de um planejamento integrado de exploração, de atitudes técnicas adequadas na operação e manutenção de poços, mas também de responsabilidade social e de consciência sobre a escala do tempo geológico.

\section{2 Água Subterrânea em Áreas Urbanizadas}

O uso de água subterrânea em áreas urbanas tem impactado cada vez mais os aqüíferos por causa de contaminações e demandas excessivas, encarecendo o custo da água, comprometendo a saúde humana e propiciando um declínio sócio-econômico e ambiental. Dado o imediatismo do problema, é urgente a necessidade de identificar e priorizar a tomada de ações de controle, que são imprescindíveis, considerando-se a continuidade do aumento populacional (Howard, 2001).

"Durante as últimas décadas do século XX a alternativa de utilização da água subterrânea tornou-se, regra geral, a solução mais barata aos problemas de abastecimento público, industrial e até irrigação, em todas as faixas climáticas da Terra. Desta forma, a falta de um controle em prol do seu uso e proteção - Federal, Estaduais ou Municipais - torna-se cada vez mais preocupante. Em todas as áreas metropolitanas do Brasil vários milhares de poços privados e não controlados são utilizados para abastecimento de hotéis de luxo, hospitais, industrias, condomínios, postos de serviço e clubes esportivos, principalmente" (Rebouças 2002). 
A utilização da água subterrânea, no Brasil, continua sendo feita de forma empírica, improvisada e não controlada (Rebouças, 2002). Os poços construídos, operados e abandonados sem controle, se transformam em verdadeiros focos de poluição das águas subterrâneas que são extraídas, sobretudo, daqueles localizados no meio urbano (Rebouças, 2002).

A criação de conglomerados industriais muitas vezes é acompanhada de uma implantação não planejada de uma rede de poços de produção de água subterrânea. Bombeando-se a água de maneira intensiva em áreas pequenas, quando comparadas às áreas de abrangência de raios de influência de poços, estes raios se sobrepõem entre si, agravando o rebaixamento de nível d'água. Este problema aumenta ao se considerar que os efluentes gerados nas indústrias são comumente descartados em áreas de contribuição ao aqüífero explorado. Assim, contaminantes infiltrados podem ser levados a horizontes mais profundos do aqüífero.

Num estudo realizado pelo serviço geológico dos EUA (USGS, 2006), a ocorrência de PCE foi estatisticamente associada, entre outras, à porcentagem de utilização dos solos urbanos e à densidade de sistemas sépticos.

Fontes de produtos químicos introduzidos para as águas subterrâneas são classificadas como "fontes pontuais" ou "fontes não-pontuais" (USGS, 1999). São consideradas fontes pontuais, por exemplo, as áreas de descarte de efluentes industriais, tanques com vazamento de produtos químicos, ocorrências de derramamentos decorrentes de operações de produção ou transporte de produtos, fossas e aterros (USGS, 1999), exemplos típicos de atividades em meio urbano.

São consideradas fontes não-pontuais de contaminação as áreas agrícolas, tais como, plantações, por causa da amplitude da área em que os contaminantes, como fertilizantes, adubos e pesticidas são espalhados (USGS, 1999). Áreas agrícolas incluem também inúmeras fontes pontuais, tais como, currais, resíduos de lagoas e galpões para armazenamento de agrotóxicos (USGS, 1999).

De uma perspectiva regional, áreas urbanas podem ser consideradas fontes não-pontuais quando apresentarem uma vasta gama de fontes pontuais que afetam regionalmente o aqüífero. Efeitos de contaminações regionais sobre a qualidade do aqüífero são particularmente importantes do ponto de vista de gerenciamento do recurso hídrico, se a água do lençol freático abaixo de terrenos urbanos, por exemplo, é usada, ou pode ser usada, como uma fonte de abastecimento (USGS, 1999). 


\subsection{Solventes Organoclorados}

O solvente é um composto usado para dissolver outras substâncias e o solvente clorado, composto orgânico que contém cloro, é utilizado em diversas aplicações, principalmente industriais, mas também comerciais e domésticas (USGS, 2006).

Dois dos solventes mais comuns são os solventes clorados tricloroeteno (TCE) e percloroetileno (PCE). Em geral, os solventes clorados têm densidade, pressão de vapor e solubilidade relativamente altas, e meia-vida longa, na água subterrânea. Os solventes clorados são compostos antropogênicos, ou seja, ocorrem no meio ambiente primeiramente como resultado da atividade humana (USGS, 2006). O PCE, o TCE e o tricloroetano (TCA) são solventes industriais amplamente utilizados como desengraxantes de metal e em operações de lavagem a seco (Sims et al 1991).

Os etenos clorados e os etanos clorados, que são os compostos de interesse deste trabalho, são compostos orgânicos halogenados alifáticos, ou seja, constituídos de átomos de carbono, hidrogênio e um átomo não metálico, nestes casos do elemento cloro, ligados entre si em uma cadeia aberta (USGS, 2006).

Conforme Salgado e Marona (2004) dentre os compostos orgânicos alifáticos, os mais destacados em relação a potenciais prejuízos à saúde humana são o cloreto de vinila (CV), o PCE e o TCE. O CV é comprovadamente carcinogênico em humanos, sendo o câncer de fígado o mais estudado. O PCE é considerado carcinogênico pelo Departamento de Saúde e Serviços Humanos dos Estados Unidos e pela Agência Internacional de Pesquisa do Câncer. Segundo USGS (2006) o TCE é classificado como provável carcinogênico em humanos. Conforme USEPA (2009), efeitos sobre a saúde por exposição a compostos como o PCE e o TCE dependem de alguns fatores, tais como: nível de exposição, tempo de exposição, idade do indivíduo, exposição simultânea a outros compostos, condições de saúde intrínsecas do indivíduo.

A produção de solventes organoclorados nos EUA começou no início do século $X X$, e aumentou, espalhando-se pelo mundo após a 2ª . Guerra Mundial. O pico de produção de TCE nos EUA ocorreu em 1970 e, do PCE, em 1980. A partir daí a produção de ambos declinou até a década de 90, voltando a subir levemente a partir da metade da década de 90 (USGS, 2006).

Conforme Huling e Weaver (1991) os solventes clorados são os contaminantes mais citados entre os produtos denominados Dense Nonaqueous Phase Liquids (DNAPL). O termo pode ser traduzido como: fase líquida densa e não aquosa. 


\subsection{Solventes Organoclorados e Poços de Produção}

\subsubsection{Comportamento de compostos organoclorados em aqüíferos}

A contaminação dos aqüíferos por compostos organoclorados é resultado de uma produção e utilização intensa destes produtos em diversas indústrias, de práticas precárias de gestão de efluentes e resíduos, bem como de certas características físico-químicas que facilitam a propagação destes contaminantes nas zonas não-saturada e saturada (Graber et al, 2008).

As propriedades físico-químicas dos compostos organoclorados incluem a imiscibilidade em água, embora apresente alta solubilidade aquosa ao se considerar os níveis de potabilidade admissíveis, densidades superiores à da água, viscosidades inferiores à da água, altas pressões de vapor, coeficientes de sorção relativamente baixos e relativa persistência à biodegradação (Pankow e Cherry, 1996).

Solventes clorados, em fase não-aquosa, quando em quantidade suficiente para vencer pressões capilares, se aprofundam no aqüífero. Uma vez que o nível d'água é penetrado, fluxos laterais de substâncias dissolvidas na água são mediados pelo fluxo regional da água subterrânea, porém, devido a sua densidade maior do que a da água, o movimento de fase livre ainda é direcionado verticalmente até que corpos de baixa permeabilidade sejam atingidos. Uma vez que uma camada impermeável é atingida, passa a ocorrer um fluxo lateral. Esta movimentação ocorre mesmo contra o sentido de fluxo natural da água subterrânea, por efeito da gravidade (USGS, 2006).

No subsolo, o solvente organoclorado se associa em fases distintas às diferentes matrizes presentes no ambiente subterrâneo. A Tabela 1 apresenta as matrizes e respectivas fases em que um DNAPL pode ocorrer.

Tabela 1 - Distribuição de fases do DNAPL no subsolo.

\begin{tabular}{|l|l|}
\hline \multicolumn{1}{|c|}{ matriz } & \multicolumn{1}{c|}{ fase } \\
\hline água subterrânea & aquosa - componentes solúveis do DNAPL \\
\hline solo / componentes do aqüífero & sólida - compostos adsorvidos de DNAPL no material sólido \\
\hline DNAPL & imiscível - fase livre (móvel) fase residual (imóvel) \\
\hline gás do solo & gasosa - componentes voláteis do DNAPL \\
\hline
\end{tabular}

Fonte: (Huling e Weaver, 1991)

Em alguns casos, as concentrações de PCE e TCE têm se mostrado crescentes com o aumento da profundidade no aqüífero. Por causa de suas propriedades, quando puros, mais 
densos do que a água, estes produtos se movem através da água por caminhos preferenciais e acumulam-se em lentes ou topos de camadas menos permeáveis. Neste caso, tornam-se uma fonte de contaminação, a partir deste ponto para o aqüífero. Através de dissolução, dispersão e difusão, a massa do solvente move-se para determinadas direções e forma gradientes de concentrações que crescem na direção do ponto de ocorrência do produto puro (USGS, 2006).

O conhecimento da localização, distribuição, concentração e massa total dos contaminantes adsorvidos aos solos ou presentes como DNAPL em fase livre ou residual é necessário para calcular o particionamento do DNAPL contaminante em águas subterrâneas. Esta informação é útil para estimar a persistência a longo prazo de áreas fonte secundárias (USEPA, 1998).

Uma vez presente no meio fraturado, o DNAPL, lentamente, é dissolvido na água subterrânea, fluindo pelas fraturas abertas e gerando plumas de fase dissolvida. Em geral, estas plumas migram, por advecção, em direção às zonas de menor potencial hidráulico, sujeitas a processos de dispersão, adsorção (nos planos de fratura), biodegradação e difusão na matriz rochosa (Environment Agency, 2003). O DNAPL pode adentrar a matriz rochosa, por difusão, em alguns meses de contato do contaminante, puro ou dissolvido na água, com a rocha. Já o processo inverso, ou seja, para que o contaminante presente na matriz rochosa passe completamente para uma água limpa em contato com a rocha, por difusão, demoraria séculos (Environment Agency, 2003).

Os solventes organoclorados caracterizam-se por apresentar uma cadeia de degradação, ou seja, a quebra de substâncias que ocorre através de processos bióticos ou abióticos. A Figura 7 ilustra a cadeia de degradação a partir do etano clorado TCA e do eteno clorado PCE.

O TCA pode degradar para 1,1-Dicloroetano (1,1-DCA) e para 1,1- Dicloroeteno (1,1DCE). O PCE degrada para TCE. O TCE degrada por desalogenação redutiva sob a perda de um átomo de $\mathrm{Cl}$ e a adição de uma átomo de hidrogênio, podendo formar três possibilidades de produtos na reação: 1,1-DCE; cis-1,2-DCE ou trans-1,2-DCE (Sims et al 1991).

O 1,1-DCE pode sofrer desalogenação redutiva para formar CV, ou a ligação dupla de carbono pode ser quebrada formando 1,1-DCA (Sims et al 1991).

O cis-1,2-Dicloroeteno (cis-1,2-DCE) e o trans-1,2-Dicloroeteno (trans-1,2-DCE) podem sofrer desalogenação redutiva para formar CV, ou a ligação dupla de carbono pode ser quebrada formando 1,2-DCA (Sims et al 1991).

O 1,1-DCA e o 1,2-Dicloroetano (1,2-DCA) podem sofrer deidroalogenação para formar CV ou podem sofrer desalogenação redutiva e formar cloroetano (Sims et al 1991). 


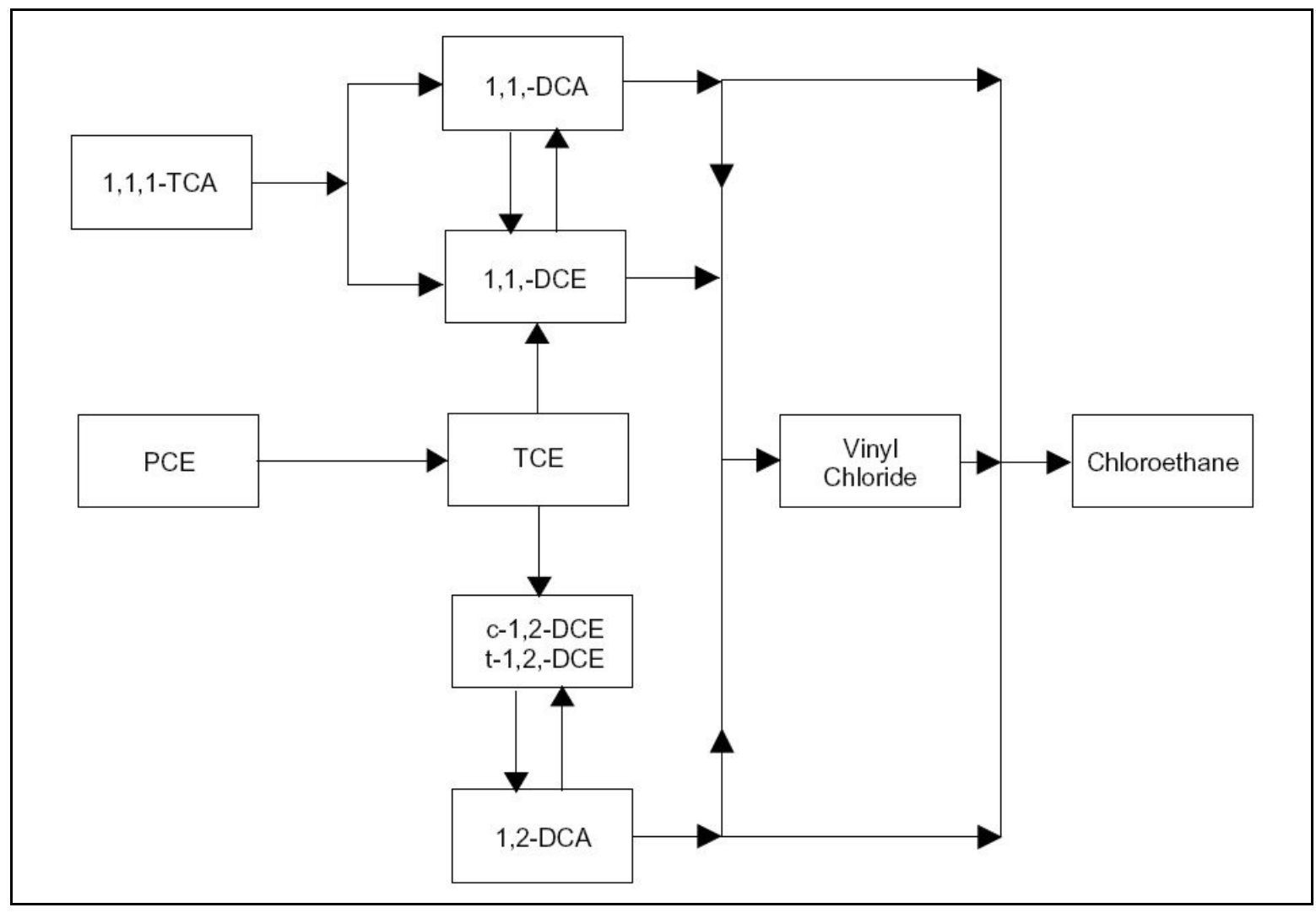

Fonte: (Sims et al, 1991)

Figura 7- Cadeia de degradação a partir do etano clorado TCA e do eteno clorado PCE.

A persistência dessas substâncias na água subterrânea depende das características meio. A degradação do PCE para TCE ocorre tipicamente por processos bióticos, ou seja, pela ação de microorganismos. Já a degradação de TCA para 1,1-DCE é tipicamente abiótica (USGS, 2006).

\subsubsection{Monitoramento de VOC do Serviço Geológico dos EUA (USGS)}

O United States Geological Services (USGS) realizou uma investigação em todo o território dos EUA, analisando 55 compostos orgânicos voláteis em 98 aqüiferos. Foram consideradas 3500 amostras coletadas entre 1985 e 2001, em vários tipos de poços de monitoramento, sendo 2400 poços privados e 1100 poços públicos, gerando informações para diversos órgãos gestores e tomadores de decisão. Estes resultados foram publicados em 2006 no documento da USGS denominado Circular 1292.

Em análises com o limite de detecção a $0,02 \mu \mathrm{g} / \mathrm{L}$ foram detectados um ou mais VOC em $50 \%$ das amostras. Em análises com o limite de detecção a $0,2 \mu \mathrm{g} / \mathrm{L}$, esta relação diminuiu para $20 \%$ das amostras. Foram detectados VOC em 90 dos 98 aqüíferos investigados. 
Dos 55 VOC analisados, foram detectados 42, sendo que 15 VOC ocorreram em acima de $1 \%$ das amostras. Entre os 15 compostos mais freqüentes estão 7 solventes, 4 trialometanos, 2 refrigeradores (CFC) e 2 derivados de petróleo. O PCE e o TCE ocorreram, respectivamente, como o segundo e o quarto VOC mais freqüente.

O PCE, o TCE e o 1,1-DCE foram detectados tanto em poços públicos, quanto em poços privados. O CV foi detectado apenas em poços públicos.

Em cerca de 3450 poços analisados, a um limite de detecção de 0,2 microgramas/l, foram detectados, em números aproximados, PCE em 215 poços, TCE em 154 poços, cis-1,2-DCE em 15 poços, trans-1,2-DCE em 31 poços, 1,2-DCA em 16 poços, TCA em 59 poços e CV em 9 poços. Estes números foram obtidos a partir da porcentagem de detecções para cada composto, sendo que o número de poços amostrados varia em torno de 3450 poços (USGS, 2006).

A detecção de VOC foi maior em poços públicos do que em poços privados. Isso foi atribuído, em parte, às maiores taxas de bombeamento que os poços públicos operam e à proximidade de poços públicos a áreas mais industrializadas. As maiores taxas de bombeamento aumentam a movimentação e a captura de VOC e a proximidade de poços públicos às áreas fonte é bastante comum (USGS, 2006).

Este estudo do USGS conclui que a contaminação por VOC nos aqüíferos não é determinada unicamente pela existência das fontes de contaminação, mas também por fatores naturais e antropogênicos que afetam o transporte e o comportamento do VOC no aqüífero. Por exemplo, a ocorrência de PCE esteve estatisticamente associada com a porcentagem de ocupação urbana e densidade de fossas próximas a poços de produção, à profundidade de seção filtrante em relação ao topo do poço e, à presença de oxigênio dissolvido no aqüífero. Entretanto, conclui-se que são necessários estudos adicionais, em escala local, para ajudar a explicar, de maneira mais precisa, as razões para as ocorrências de VOC.

\subsubsection{Estudos de caso}

Foram selecionados alguns casos de contaminação sob uma triagem pautada na ocorrência de contaminantes organoclorados alifáticos em poços públicos. O critério de selecionar organoclorados alifáticos foi adotado na intenção de encontrar similaridades com o estudo de caso do Jurubatuba, onde a contaminação regional ocorre por estes mesmos compostos. O critério de condicionar esta seleção ao fato destes contaminantes terem atingido poços públicos visou a obtenção de informações sobre casos que assumiram maior importância por representarem risco à população e, por terem ocasionado tomadas de ações, 
relativamente, mais prudentes e regulares. Com isso, pôde-se observar peculiaridades em suas metodologias de investigação, monitoramento e gerenciamento, bem como de semelhança de cenários ambientais e proporções de detecções dos compostos de interesse nos monitoramentos.

Foram observados diversos casos dos EUA com ocorrência de compostos organoclorados em poços de produção. Um caso de Tel Aviv, Israel (Graber et al, 2008), apresentou características bastante semelhantes ao do Jurubatuba, tanto por ocorrer em área predominantemente industrial e metropolitana, quanto pelo número de amostragens e detecções dos compostos de interesse. Um caso de Adelaide, Austrália e outro de Ljubljana, Eslovênia, também apresentam semelhanças como estas, entretanto, não foram encontrados artigos que subsidiassem dados fundamentais, para apresentar os casos com confiabilidade.

Os casos verificados que ocorreram nos EUA foram sete, nas seguintes cidades: Cheshire, Long Island, Easthemptom, Woburn, Aberdeen, Tumwater e Bakersfield. Foram pesquisados em revistas de hidrogeologia e de contaminação e nos sítios de agências ambientais na internet. É provável que a disponibilidade de casos quase que exclusiva de exemplos dos EUA tenha correlação com os seguintes motivos: é o país mais industrializado, onde mais ocorre e mais se estudou áreas contaminadas, onde as agências ambientais estão mais avançadas, onde mais se publica artigos sobre o tema e, por fim, onde a os estudos estão mais informatizados.

A Tabela 2 apresenta características das ocorrências de contaminações por compostos organoclorados alifáticos que atingiram poços de produção público, bem como algumas medidas de investigação e gerenciamento dos casos.

Os Programas de Proteção de Poço empreendidos pela agência ambiental do EUA (USEPA) representam um esforço para proteger a qualidade da água subterrânea e a sustentabilidade de recursos subterrâneos locais, especificamente, para proteger a qualidade de água subterrânea que é bombeada a partir de poços de produção público. A abordagem destes programas consiste no levantamento de dados sobre o lençol freático, na identificação de áreas que contribuem para a recarga do aqüífero bombeado por estes poços e, em seguida, na aplicação de práticas de proteção, relativas ao uso e ocupação da superfície terrestre, nestas áreas de contribuição (USGS, 1999). 
Tabela 2 - Exemplos de casos de ocorrência de poços de produção público que foram impactados por contaminações de compostos organoclorados.

\begin{tabular}{|c|c|c|}
\hline ocorrência & investigação & gerenciamento \\
\hline \multicolumn{3}{|c|}{ Cheshire - Connectcut - EUA (USEPA, 2009) } \\
\hline $\begin{array}{l}1979 \text { - TCE é detectado num } \\
\text { poço de produção para } \\
\text { abastecimento público do } \\
\text { Campo de Poços do Norte. } 1982 \\
\text { - TCE é detectado em poços do } \\
\text { Campo de Poços do sul. }\end{array}$ & $\begin{array}{l}\text { Mapeamento de mudança de } \\
\text { uso e ocupação do solo, e } \\
\text { revisão de regulamentação de } \\
\text { proteção de aqüífero. } \\
\text { Investigações ambientais para } \\
\text { implantação de sistema de } \\
\text { remediação. }\end{array}$ & $\begin{array}{l}\text { Além da desativação de poços e } \\
\text { da remediação, é proposta uma } \\
\text { regulamentação para o uso do } \\
\text { solo nas zonas de contribuição } \\
\text { para os campos de poços, } \\
\text { proibindo determinadas } \\
\text { atividades ou condicionando-as à } \\
\text { obrigatoriedade de conexão ao } \\
\text { sistema público de fornecimento } \\
\text { de água. }\end{array}$ \\
\hline
\end{tabular}

Long Island - New York - EUA (Eckhardt e Stackelberg, 1995)

1980 - Monitoramento detecta

VOC em 33 de 90 poços amostrados. Detecta-se compostos organoclorados, principalmente TCA e TCE, em poços públicos, não enumerados
Cruzamento de pontos de detecção de contaminação com o tipo de uso e ocupação do solo.
Utilização de resultados para a priorização de áreas a serem investigadas em detalhe, com indicação de tipo de análises químicas e diretrizes para o estabelecimento de rede de monitoramento.

Woburn - Massashussetes - EUA (USEPA, 2009)

1982 - Pluma de PCE e TCE atinge 2 poços públicos e observa-se impactos na saúde da população (leucemia infantil, arritmia cardíaca, distúrbios em sistemas neurológico e imunológico).
Órgão municipal de saúde amostra e não detecta contaminantes. 1979 - Órgão estadual ambiental amostra e encontra diversos contaminantes.
Retirada dos poços da linha de abastecimento. Investigações detalhadas e remediações em escala local.

Easthemptom - Massashussetes - EUA (Platt e Klejna, 2009)

1984 - Pluma de TCE atinge 2 poços públicos do sistema aqüífero Barnes, que fornece água potável para 6000 pessoas.
Caracterização de uso e ocupação e verificação de alta vulnerabilidade natural do aqüífero
Fechamento dos poços e coordenação de uso e ocupação de solo por comitê composto por 4 cidades que compartilham o aqüífero. É criado um programa de aquisição de áreas de aqüífero. 


\begin{tabular}{|c|c|c|}
\hline ocorrência & investigação & gerenciamento \\
\hline \multicolumn{3}{|c|}{ Aberdeen Moore County - Carolina do Norte - EUA (USEPA, 2009) } \\
\hline $\begin{array}{l}1990 \text { - Contaminação por TCE } \\
\text { detectada em poços privados. } \\
2007 \text { - a contaminação atinge } 2 \\
\text { poços públicos que são mantidos } \\
\text { em operação, ligados a uma rede } \\
\text { composta por } 17 \text { poços. }\end{array}$ & $\begin{array}{l}\text { Investigações em escala local } \\
\text { em diversas industrias e } \\
\text { integração de dados em maior } \\
\text { escala pela órgão estadual de } \\
\text { controle de água subterrânea. }\end{array}$ & $\begin{array}{l}\text { Investigações detalhadas e } \\
\text { remediações em escala local. } \\
\text { Estabelecimento de rede de } \\
\text { monitoramento. } 1991 \text { - Foi } \\
\text { determinado que } 40 \text { comércios e } \\
\text { residências fossem conectados ao } \\
\text { sistema de abastecimento de } \\
\text { água municipal. }\end{array}$ \\
\hline \multicolumn{3}{|c|}{ Tumwater - Washington - EUA (USEPA, 2009) } \\
\hline $\begin{array}{l}1993 \text { - Monitoramento periódico } \\
\text { detecta TCE e PCE em } 3 \text { de } 6 \\
\text { poços públicos do campo de } \\
\text { poços de Palermo. }\end{array}$ & $\begin{array}{l}\text { USEPA investiga e constata que } \\
\text { a pluma provêm de uma área } \\
\text { comercial vizinha, atravessa } \\
\text { uma área residencial e atinge } \\
\text { os poços. }\end{array}$ & $\begin{array}{l}\text { O site torna-se área contaminada } \\
\text { prioritária, a ser incluída em } \\
\text { programa financiado de } \\
\text { recuperação. Os } 3 \text { poços atingidos } \\
\text { são desativados. Promove-se a } \\
\text { remediação da água subterrânea } \\
\text { e do solo próximo à área fonte. }\end{array}$ \\
\hline
\end{tabular}

Área metropolitana de Tel Aviv - Israel (Graber et al, 2008)

2001 - Monitoramento detecta

VOC-Cl em 74 de 90 poços amostrados. TCE e PCE são os principais contaminantes e atingem poços públicos (não enumerados).
Monitoramentos periódicos e caracterização geral de aqüíferos
Proposta de realização de estudos locais e intensificação de monitoramento da rede de poços a ser definida para embasar decisões futuras.

Área metropolitana de Bakersfield - California - EUA (USEPA, 2009)

2003 - Monitoramento detecta VOC em 32 de 43 poços públicos amostrados, nos campos de poços denominados Norte e Sul. Detecta-se compostos organoclorados, principalmente PCE e TCE.

\section{Programa Estadual de} Monitoramento e Investigação Ambiental de Água Subterrânea utiliza método de ultradetecção de contaminantes, associando ocorrências à idade da água.
Concluí-se que as águas contaminadas são as de recarga recente e as águas antigas estão livres de contaminantes, indicando, portanto, um melhor controle de manejo de produtos nas áreas de recarga. 
As metodologias aplicadas para a caracterização da área, o entendimento da contaminação e o gerenciamento dos casos, nos diversos casos estudados, são similares entre si e também aos métodos utilizados e aos propostos para o Jurubatuba. Exemplos destes métodos são: proceder com abordagens locais e regionais, analisar o uso e a ocupação do solo ao longo do tempo, executar experimentos de campo para a obtenção de parâmetros hidráulicos, realizar monitoramentos químicos periódicos, interceder sobre a utilização da água, proceder investigações detalhadas e remediação e estabelecer medidas regulamentares para fazer valer decisões gerenciais.

Dado o fato de que os DNAPL migram a uma profundidade considerável em sistemas rochosos, deve-se ter um cuidado especial ao considerar atividades de perfuração destinadas a determinar a profundidade total de migração do contaminante. Na maioria das áreas contaminadas, a profundidade total de migração do contaminante em meio rochoso fraturado não é determinada. Isso decorre do fato de que a perfuração através de áreas-fonte secundárias de DNAPL (piscinas ou bolsões de contaminante) traz consigo um risco de remobilização de DNAPL, permitindo-Ihe aprofundar mais em casos onde estiver acomodado em sub-superfície. Ocorre também que o DNAPL não entra em todas as fraturas de um sistema fraturado e, por isso, seria necessário um grande número de sondagens para estimar a profundidade total de migração do contaminante. Tal exercício é muitas vezes impedido pelo custo (Kueper et al, 2003).

Além disso, o conhecimento da profundidade total de migração do contaminante, muitas vezes, é de pouco uso prático, porque tecnologias de remediação são atualmente incapazes de remover completamente o DNAPL a partir de grandes profundidades nos sistemas rochosos. A pluma de fase dissolvida fase é tipicamente a forma de contaminação mais móvel. Esforços de perfuração são, portanto, muitas vezes centrados na determinação da direção e velocidade de migração da pluma, com especial ênfase na coleta de dados para avaliar os riscos potenciais para identificar receptores (Kueper et al, 2003).

Com isso, tem-se que um bom caminho para lidar com contaminações por solventes organoclorados em aqüíferos fraturados é conhecer a geologia e a hidrogeologia da área a ponto de desenvolver modelos conceituais factíveis; conhecer, monitorar e remediar a área contaminada em sub-superfície; conhecer o uso e a ocupação do solo visando impedir a exposição de receptores à contaminação; e utilizar-se de uma participação integrada de usuários dos terrenos e gestores ambientais na implantação e aplicação de medidas de gerenciamento para a recuperação ambiental e a eliminação de risco à saúde humana. 


\subsection{Principais Órgãos Gestores e Legislação Brasileira Aplicada}

\subsection{1 Órgãos Gestores Atuantes}

Pode-se dizer, resumidamente, que, em aplicação ao estudo de caso do Jurubatuba, o Departamento de Águas e Energia Elétrica (DAEE) controla o uso da água; a Companhia de Tecnologia de Saneamento Ambiental (CETESB), combate a contaminação; e a Coordenação de Vigilância em Saúde (COVISA), acompanhada pelo Centro de Vigilância Sanitária (CVS), zelam pela saúde do usuário da água.

Como se pode observar na apresentação do histórico deste estudo, estes órgãos gestores são os principais atuantes na intervenção provisória e na tomada de ações para a definição de medidas adequadas do uso da água subterrânea na região do Jurubatuba. Destaca-se ainda a CTAS-CRH, como entidade mediadora da integração entre os órgãos supracitados, favorecendo as inciativas conjuntas entre os órgãos gestores.

O DAEE, criado em dezembro de 1951, é o órgão gestor dos recursos hídricos do Estado de São Paulo. Para desenvolver suas atividades, e exercer suas atribuições conferidas por lei, atua de maneira descentralizada, no atendimento aos municípios, usuários e cidadãos, executando a Política de Recursos Hídricos do Estado de São Paulo, bem como coordenando o Sistema Integrado de Gestão de Recursos Hídricos, nos termos da Lei 7.663/91, adotando as bacias hidrográficas como unidade físico-territorial de planejamento e gerenciamento (DAEE, 2009).

A CETESB, criada em julho de 1968, é a agência do Governo do Estado de São Paulo responsável pelo controle, fiscalização, monitoramento e licenciamento de atividades geradoras de poluição, com a preocupação fundamental de preservar e recuperar a qualidade das águas, do ar e do solo (CETESB, 2009).

A COVISA, criada em 2003, é um órgão municipal que reúne diversas estruturas do campo da Vigilância em Saúde, divididas em gerências e Núcleos Técnicos. As gerências coordenam, planejam e desenvolvem projetos, programas e ações de orientação, educação, intervenção e fiscalização, pertinentes às suas respectivas áreas de atuação. Assim como desenvolvem investigação de casos ou de surtos e assumem a operação de situações epidemiológicas de doenças de notificação compulsória ou agravos inusitados de saúde, também elaboram normas técnicas e padrões destinados à garantia da qualidade de saúde da população (PMSP, 2009). O CVS é o órgão estadual de saúde. 


\subsubsection{Legislação brasileira aplicada}

Pela Constituição Federal de 1988, todas as águas do Brasil passaram a ser um bem natural de domínio público, sendo apresentadas como bens dos Estados (art. 26): "as águas superficiais ou subterrâneas, fluentes, emergentes e em depósito, ressalvadas, neste caso, na forma da lei, as decorrentes de obras de União" (Rebouças, 2002).

A Lei da Política Nacional de Meio Ambiente, no 6938/81, oferece, de forma ampla, a devida proteção ao meio ambiente, agregando conceitos das ciências ao normativo jurídico (Souza, 2004). A Lei Federal de no 9433/97, lei da Política Nacional de Recursos Hídricos, dita as regras gerais e, as resoluções e portarias dos diversos órgãos federais buscam regulamentá-la. Porém, quanto aos recursos hídricos subterrâneos, cabe aos Estados membros legislarem sobre sua gestão e, através dos órgãos estaduais é que se tem a regulamentação dos diplomas estaduais e, por isso, a efetividade da proteção legal (Souza, 2004).

No âmbito estadual, a Lei no 6134/88, que dispõe sobre a preservação dos depósitos naturais de águas subterrâneas no Estado, em seu artigo 9º, determina que "sempre que necessário o Poder Público instituirá áreas de proteção aos locais de extração de águas subterrâneas, a fim de possibilitar a preservação e conservação dos recursos hídricos subterrâneos".

No Capítulo III do Decreto no 32955/91, que regulamenta a Lei no 6134/88, dá-se o estabelecimento de áreas de proteção. Conforme art. 20, parágrafo II, deste Decreto, as áreas de proteção podem ser classificadas como: Área de Proteção Máxima, Área de Restrição e Área de Proteção de Poços e Outras Captações. A Área de Restrição e Controle (ARC) é caracterizada pela necessidade de disciplina das extrações, controle máximo das fontes poluidoras já implantadas e restrição a novas atividades potencialmente poluidoras.

Embasada no arcabouço legal supracitado, a Deliberação do CRH no 052, de 15 de abril de 2005, instituiu diretrizes e procedimentos para a definição de áreas de restrição e controle da captação e uso das águas subterrâneas em regiões do Estado de São Paulo onde ocorrem problemas relacionados à superexplotação da água e constatação ou riscos de contaminação.

Buscando efetivar a Deliberação nº 52/05, a Portaria DAEE n 1594, de 05 de Outubro de 2005, em razão da constatação de áreas contaminadas, delimitou uma Área de Restrição e Controle Temporária na área de estudo.

Esta restrição é temporária pelo prazo de um ano, podendo ser prorrogada, sendo que neste período o DAEE não poderá emitir novas outorgas e, as captações existentes na referida 
área deverão ser restringidas e reguladas, podendo, o DAEE, vir a revogar as outorgas já emitidas ou estabelecer o regime máximo a ser extraído e o regime de operação.

A Deliberação n 52/05 estabelece que os órgãos gestores de recursos hídricos, controle ambiental e saúde proporão de forma integrada, a delimitação das áreas de controle e restrição, levando em conta os planos de bacias hidrográficas, os relatórios de situação dos recursos hídricos, os programas de monitoramento da qualidade da água e o atendimento à potabilidade, que evidencie os efeitos negativos de contaminação e explotação.

As ARC de captação e uso das águas subterrâneas são classificadas na Deliberação no 52/05 conforme segue:

a. Áreas Potenciais de Restrição e Controle (ARC-PO), que são aquelas onde a densidade de poços tubulares e o volume de água extraído, indicam superexplotação ou aquelas onde estão sendo ou foram desenvolvidas atividades potencialmente contaminadoras de solo e águas subterrâneas;

b. Áreas Prováveis de Restrição e Controle (ARC-PR), que são aquelas onde são observados indícios de superexplotação e interferência entre poços ou apresentam indícios de contaminação no solo e águas subterrâneas;

c. Áreas Confirmadas de Restrição e Controle (ARC-CO), que são aquelas em que foi constatada a superexplotação ou a contaminação das águas subterrâneas.

Para complementar o disposto nos ordenamentos legais citados, a Resolução Conjunta SMA/SERHS/SES no 3, de 21 de junho de 2006, que dispõe sobre procedimentos integrados para controle e vigilância de soluções alternativas coletivas de abastecimento de água para consumo humano proveniente de mananciais subterrâneos, estabelece procedimentos entre os órgãos e entidades dos Sistemas Estaduais do Meio Ambiente, Saúde e Recursos Hídricos para compatibilização das autorizações, licenças ambientais e do cadastro e monitoramento com as outorgas de recursos hídricos subterrâneos.

Para requerer a Outorga de Autorização de Implantação de Empreendimento junto ao DAEE, o interessado, além das exigências estabelecidas na Portaria DAEE no 717 , de 12 de dezembro de 1996, deve indicar a localização do poço, descrevendo o uso e a ocupação do solo e indicando as fontes pontuais com potencial de contaminação do solo e das águas subterrâneas ou áreas já declaradas contaminadas pela CETESB, abrangendo um raio de 500 $\mathrm{m}$ do ponto de perfuração. Nos casos com área declarada contaminada, num raio de $500 \mathrm{~m}$ do ponto da perfuração, o usuário deverá apresentar ao DAEE Parecer Técnico da CETESB, referente à qualidade ambiental. Da mesma maneira deve-se proceder quando o poço estiver em ARC declarada pelo $\mathrm{CRH}$. 
O artigo 10 da Resolução n 3/06, ao prever que para fins de monitoramento da qualidade da água para consumo humano e seu padrão de potabilidade, além das exigências descritas na Portaria do Ministério da Saúde № 518, de 25 de março de 2004, o usuário deverá apresentar à autoridade sanitária competente, laudos analíticos da água conforme os parâmetros e freqüência determinados pelo órgão ambiental em locais onde existam áreas contaminadas em um raio de até $500 \mathrm{~m}$ do ponto de perfuração do poço.

A Portaria no 518 estabelece os procedimentos e responsabilidades relativas ao controle e vigilância da qualidade da água para consumo humano e seu padrão de potabilidade e, dá outras providências. Ressalta que toda a água destinada ao consumo humano deve obedecer ao padrão de potabilidade e está sujeita à vigilância da qualidade da água, ressalvadas as águas envasadas e outras, cujos usos e padrões de qualidade são estabelecidos em legislação específica.

A referência de concentração de compostos na água subterrânea é a lista de Valores Orientadores de Intervenção (VOI) da CETESB. Os Valores Orientadores da CETESB foram estabelecidos pela Decisão de Diretoria no 195-2005-E, de 23 de novembro de 2005. "O Valor de Intervenção (VI) é a concentração de determinada substância no solo ou na água subterrânea acima da qual existem riscos potenciais, diretos ou indiretos, à saúde humana, considerado um cenário de exposição genérico" (CETESB, 2005).

"Para a água subterrânea, considerou-se como valores de intervenção as concentrações que causam risco à saúde humana listadas na Portaria 518, de 26 de março de 2004, do Ministério da Saúde, complementada com os padrões de potabilidade do Guia da Organização Mundial de Saúde (OMS) de 2004, ou calculados segundo adaptação da metodologia da OMS utilizada na derivação destes padrões" (CETESB, 2005).

Uma área "é classificada como Área Contaminada sob Investigação quando houver constatação da presença de contaminantes no solo ou na água subterrânea em concentrações acima dos Valores de Intervenção, indicando a necessidade de ações para resguardar os receptores de risco" (CETESB, 2005).

A Resolução no 396 do Conselho Nacional de Meio Ambiente (CONAMA), de 03 de abril de 2008, dispõe sobre a classificação e diretrizes ambientais para enquadramento das águas subterrâneas e dá outras providências. 


\section{MATERIAIS E MÉTODOS}

Os trabalhos foram desenvolvidos com o reconhecimento da área de estudo, o levantamento e organização de dados preexistentes, a utilização de resultados obtidos em trabalhos de campo e o tratamento e interpretação de dados.

Devido à ocorrência simultânea deste projeto de mestrado com o projeto DAEE-Servmar, houve a oportunidade de realizar reuniões técnicas unindo representantes de órgãos gestores, a equipe técnica da Servmar, o autor da dissertação e o orientador do mestrado. A realização destas reuniões propiciou uma visão integrada da situação na área de estudo e favoreceu o esclarecimento de informações e dados fundamentais para o desenvolvimento do projeto.

\subsection{Levantamento de Dados Preexistentes}

A possibilidade de acesso aos dados de interesse ocorreu essencialmente pela natureza do projeto DAEE-Servmar, no qual foram estabelecidos tratados de contribuição no fornecimento de informações pelos órgãos gestores.

Diversas fontes de dados foram necessárias para gerar bases cartográficas, o histórico do caso, informações de poços cadastrados, dados de qualidade da água dos poços e informações de detalhe de áreas contaminadas.

A coleta de informações em órgãos gestores foi realizada por solicitações formalizadas, através de ofícios emitidos, inicialmente, pela empresa Servmar e, ocasionalmente, pelo DAEE. Previamente, foram realizadas reuniões para apresentação do projeto e solicitação de dados aos detentores das informações. Os órgãos consultados foram, entre outros, o próprio DAEE, a COVISA, a CETESB, a Companhia de Saneamento Básico do Estado de São Paulo (SABESP), a Prefeitura Municipal de São Paulo (PMSP), a Empresa Paulista de Planejamento Metropolitano S.A. (EMPLASA) e o DNPM.

O cadastro de poços foi obtido a partir de cadastros preexistentes no DAEE e na CETESB. A base cartográfica principal foi obtida a partir do mapa de uso e ocupação do solo da EMPLASA. Os mapas geológico e hidrogeológico são da Fundação de Apoio à Universidade de São Paulo (FUSP). As bases com as redes de distribuição de águas e coleta de esgoto são da SABESP.

A descrição do histórico do caso baseou-se principalmente em arquivos de apresentações dos casos por órgãos públicos como a CETESB, a COVISA e a PMSP. A legislação aplicada foi baseada nos trabalhos de Souza (2004) e Souza (2006). 
Os dados de qualidade da água, ou seja, os resultados de análises químicas preexistentes provêm de diversas fontes e estavam centralizados no DAEE, na Diretoria de Bacia do Alto Tietê (DAEE-BAT). Primeiramente, estes dados provêm dos próprios autos de poços, relacionados aos pedidos de outorga. Em seguida, a partir da observação do problema regional de contaminação, cujos trabalhos realizados pela CETESB e pela COVISA intensificaram a produção de análises químicas.

O levantamento de atividades potencialmente contaminadoras foi realizado a partir da disponibilização, pela CETESB de um cadastro do seu Sistema de Fontes de Poluição (SIPOL). A relação de Áreas Contaminadas Declaradas (ACD) pela CETESB, localizadas na área de estudos, e suas respectivas fichas, foram obtidas a partir da página da CETESB na internet. As informações de detalhe de algumas das principais ACD foram acessadas na agência da CETESB de Santo Amaro.

\subsection{Visitação de Poços de Produção}

A visitação aos poços de produção foi mais uma etapa do trabalho que só foi possível pela natureza institucional do projeto DAEE-Servmar. A visitação aos poços foi realizada sob encaminhamento formal pelo DAEE e os técnicos foram identificados como representantes do DAEE.

A definição de áreas prioritárias de interesse, para a realização de trabalhos de campo, foi realizada com base em indícios ou confirmação de contaminação, tipos de receptores (usuários) da água, densidade de poços de produção e regularidade de distribuição na área de estudo.

Foram selecionados poços para a visitação com base na riqueza de informações de interesse cadastradas sobre os poços, na proximidade desses poços às Áreas Contaminadas Declaradas e no conhecimento de ocorrência de contaminação destes poços. Esta seleção visou executar medições de nível d'água, ensaios hidráulicos e coleta de amostras para análises químicas.

Previamente à visita, foi preparado um formulário com as principais questões de interesse, no qual as questões já conhecidas foram antecipadamente preenchidas e as informações obtidas em campo foram completadas. As informações estão relacionadas à observação dos poços e às entrevistas aos acompanhantes das empresas visitadas. Os poços visitados foram fotografados e, em alguns casos, foram cedidos dados de análises químicas preexistentes. 


\subsection{Ensaios de Campo}

Embora os trabalhos de campo não tenham sido uma atividade direta deste projeto de mestrado, e sim do projeto DAEE-Servmar, dada a importância fundamental dos resultados de campo para o entendimento do problema, foi observada a necessidade de descrever as metodologias dos ensaios e, não só limitar-se a trabalhar com os resultados obtidos.

Nos trabalhos de campo foram realizadas perfilagens acústicas, ensaios com obturadores e ensaios de bombeamento. Estes trabalhos serviram para observar o comportamento do aqüífero e subsidiar dados para a concepção de um modelo conceitual de fluxo.

A Figura 8 apresenta a distribuição espacial dos poços amostrados e ensaiados, sendo que a perfilagem foi executada em seis poços; os ensaios com obturadores em quatro poços com 15 amostragens de água; os ensaios de bombeamento em três poços com 7 amostragens de água; e três amostragens simples de água em outros três poços. Na Figura 8, pode-se observar também o traçado da "Área de Restrição e Controle Temporário", relativa à Portaria DAEE nำ 1594/05.

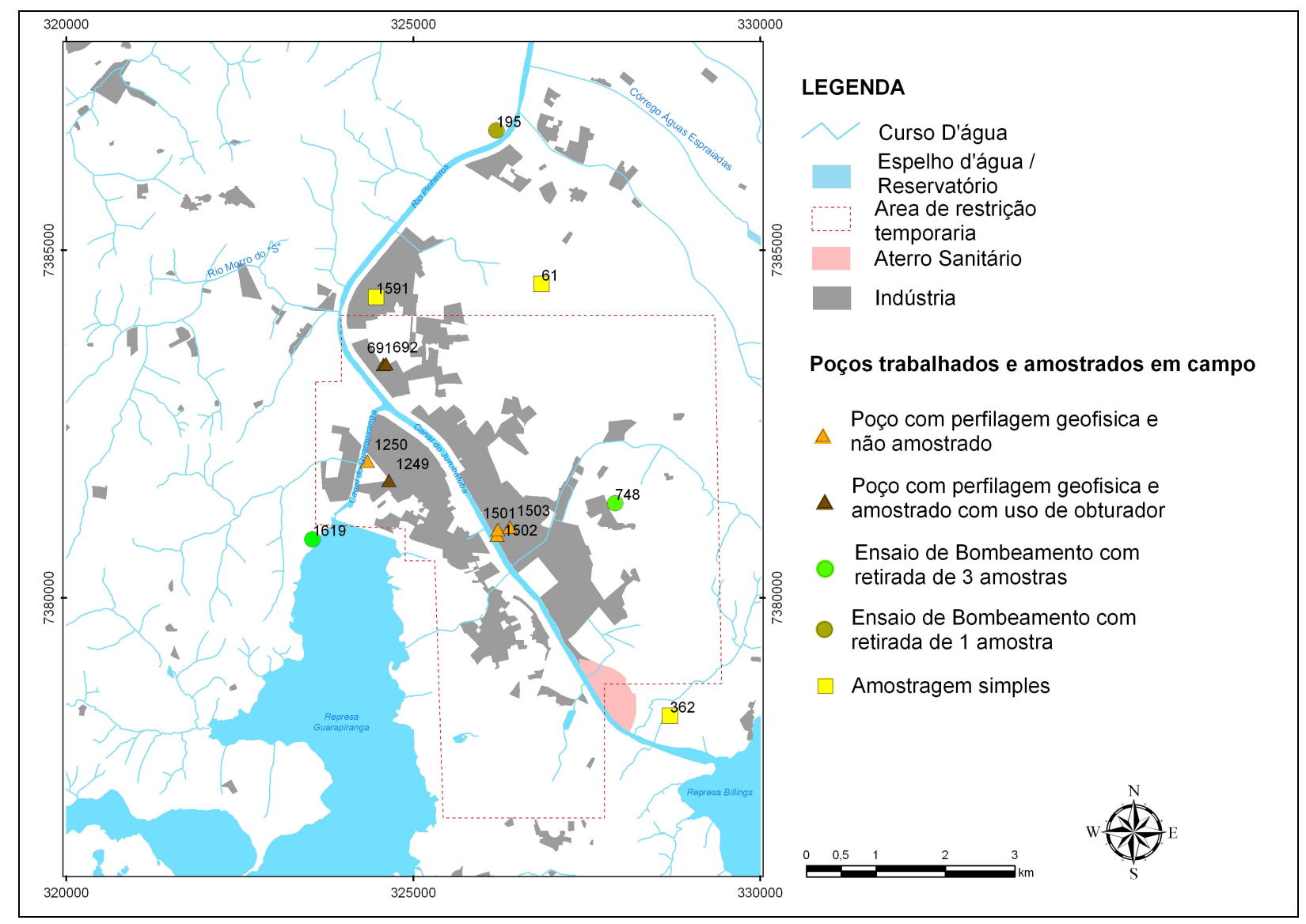

Figura 8 - Distribuição espacial dos poços ensaiados e amostrados em campo. 


\subsubsection{Perfilagens acústicas}

As perfilagens acústicas foram utilizadas para investigar feições estruturais que contribuíram para a elaboração do modelo geológico estrutural e para a definição de fraturas a serem isoladas com obturadores. Consistem no registro do tempo decorrido entre a emissão e a recepção de um pulso sonoro (Feitosa e Filho 1997). Quanto maior o espaço entre grãos ou paredes da rocha, maior o tempo de trânsito, o que indicou as porosidades. As alterações de porosidades provocam o espalhamento da onda acústica, resultando em alto contraste numa imagem digital.

O detalhamento da rocha cristalina fraturada é obtido com a investigação da espessura das fraturas, dos compartimentos estruturais homogêneos (textura, foliações) e dos compartimentos com características hidráulicas distintas, incluindo as direções de fraturas mais condutoras de água.

O imageamento acústico dos poços foi realizado com uma sonda BHTV, com cabo de $100 \mathrm{~m}$. Os resultados são obtidos a partir do processamento com a utilização do programa RGLDIP (bhtv dips log borehole deviation plots). As condições para a realização do teste são: o poço deve ter um diâmetro mínimo de $67 \mathrm{~mm}$, não estar revestido e conter água.

O transdutor é girado continuamente ao redor do eixo da sonda enviando e recebendo um pulso sônico, que viaja através do fluido do poço, em trajetória espiral e com velocidade de subida definida pelo operador. As amplitudes e o tempo de propagação do pulso resultam em imagens como as da Figura 9.

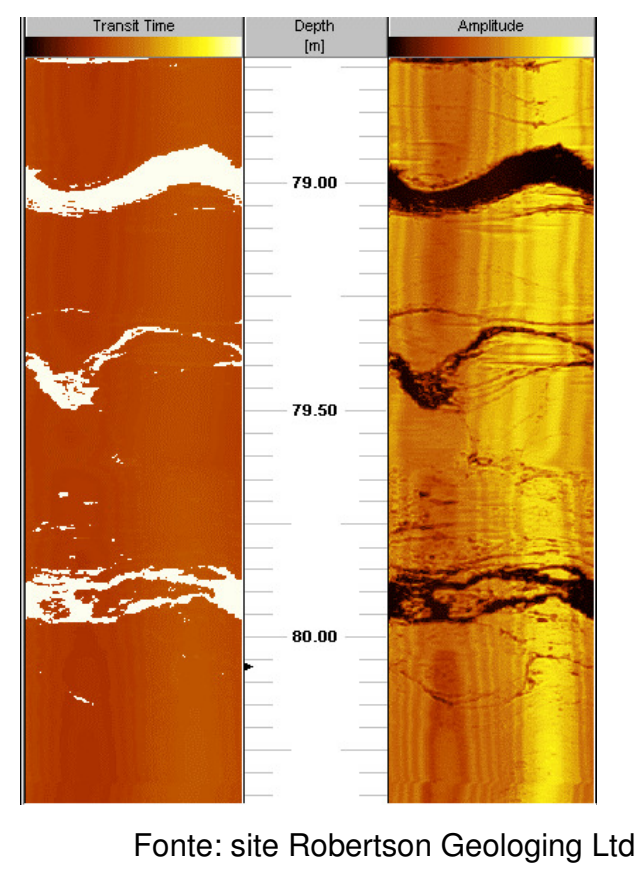

Figura 9 - Exemplo de imageamento acústico. 
O imageamento das paredes do poço ocorre ao longo dos $360^{\circ}$, permitindo a identificação de feições em relação ao eixo do poço. A perfilagem foi executada em seis poços selecionados para o uso de obturadores: 1501, 1502, 1503, 691, 692 e 1249.

\subsubsection{Ensaio com obturadores}

O isolamento de trechos com obturadores pneumáticos, posicionados em pontos selecionados ao longo do perfil de poços, permite verificar a carga hidráulica de cada trecho e, consequentemente, checar os sentidos de fluxo vertical dentro do poço. Além disso, possibilita a coleta de amostras de água de trechos específicos, para análises químicas.

Obturadores pneumáticos são equipamentos que podem ser inflados em determinadas profundidades de poços em aqüíferos fraturados, para vedar a passagem de água entre determinadas porções. A obturação permite avaliar zonas que aparentemente não possuem atividade hidráulica.

O uso de obturadores no caso de uma contaminação em aqüífero fraturado é importante para identificar a conexão entre fraturas com contaminantes e fraturas sem contaminação. Outro produto do emprego deste método é a indicação do sentido de fluxo natural da água na porção obturada. Após o isolamento e estabilização dos níveis d' água, a porção com maior carga contém os prováveis pontos de entrada de água para o poço e, o de menor carga, os pontos de saída.

Foi utilizado um arranjo com dois obturadores pneumáticos (superior e inferior) e a bomba posicionada no centro, como apresentado na Figura 10. O sistema é içado pelo tubo de sustentação, que serve para passagem da água bombeada para a superfície. Três tubos de conexão com diâmetro de 3/8 pol, servem de acesso aos intervalos intermediário e inferior do poço, por onde passam os cabos elétricos da bomba. Os obturadores de borracha em formato cilíndrico (cor preta) são expandidos quando é injetado gás $\left(\mathrm{N}_{2}\right)$ ou ar comprimido.

O isolamento de trechos permite verificar diferenças de cargas entre trechos, através do monitoramento periódico da vazão constante e do nível d'água, para observar sentidos de fluxo e permite coletar amostras de água específicas das porções obturadas.

Inflando os dois obturadores simultaneamente, com a bomba posicionada entre eles, é possível obter informações do trecho específico, isolado entre os obturadores. No caso de se inflar apenas o obturador superior, os ensaios e a amostragem são realizados na porção do aqüífero abaixo desse obturador. Quando apenas o obturador inferior é inflado, os trabalhos podem ser realizados no intervalo acima desse obturador. 


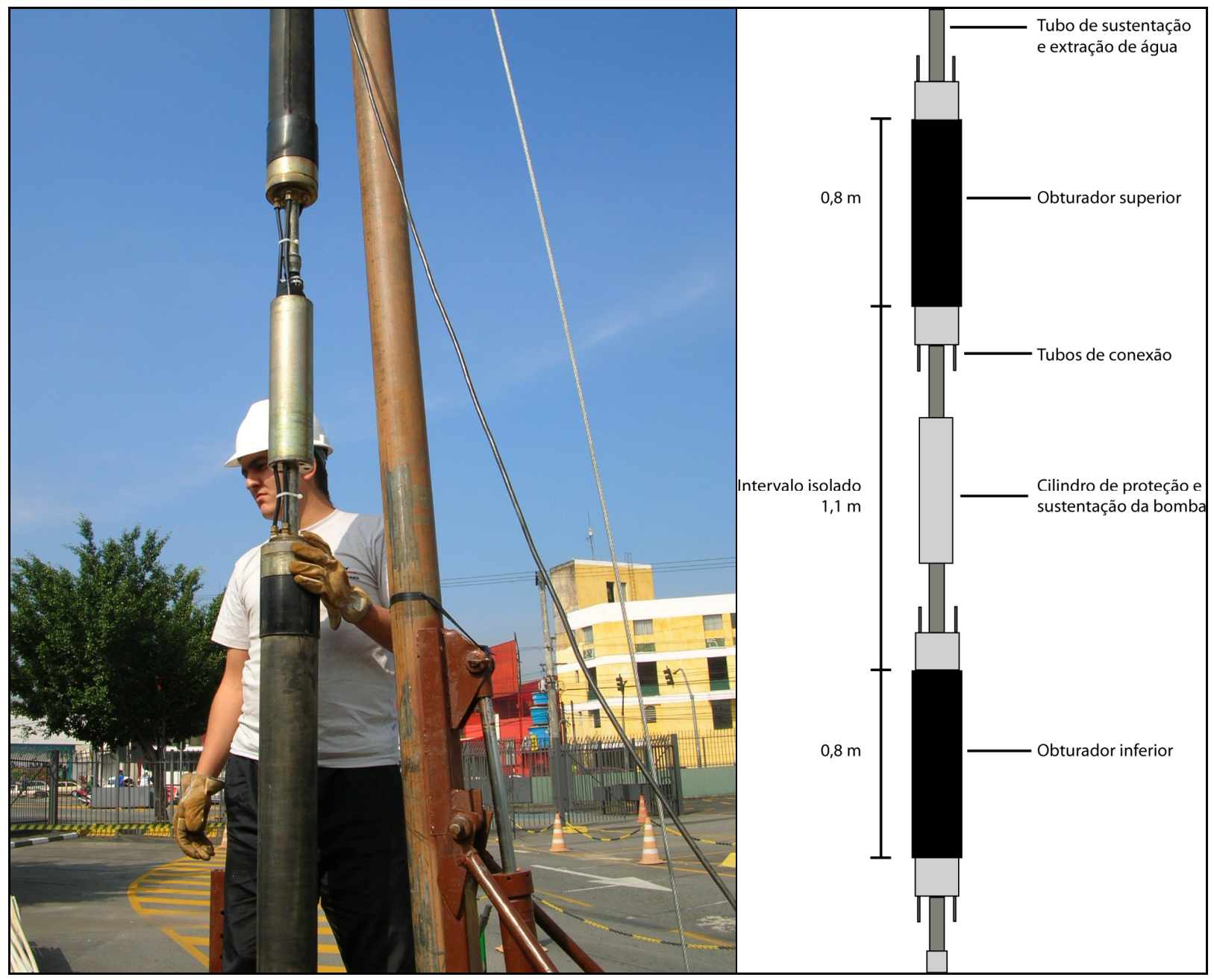

Figura 10 - Estrutura do equipamento Obturador Pneumático.

A seqüência de procedimentos para os ensaios hidráulicos com obturadores ocorreu de acordo com as seguintes etapas: as posições dos obturadores são definidas a partir da litologia e perfilagens acústicas; os obturadores são posicionados nas profundidades para os testes, e em seguida, monitora-se o nível d’água, manualmente, para ser usado como referência dos níveis obturados; os obturadores são inflados; as medições começam um pouco antes do fechamento completo da seção com os obturadores e, o momento em que ocorre o isolamento é identificado por um aumento repentino do nível d'água. Espera-se que os níveis d'água isolados se estabilizem e no caso de variações imediatas, procura-se um reposicionamento.

Após as medidas de carga hidráulica nas porções obturadas, são medidos os parâmetros físicos e físico-químicos da água por meio de célula de fluxo (modelo QED MP20), o que permite a coleta de água após estabilização desses parâmetros.

Utilizou-se uma bomba pneumática da marca Grundfos, modelo Redi-Flo2, que permite uma regulagem precisa da vazão com o emprego de um inversor de freqüência. A medição de 
vazão é feita com um hidrômetro da marca LAO, para vazão mínima de 0,03 $\mathrm{m}^{3} /$ hora e nominal de $1,5 \mathrm{~m}^{3} /$ hora.

A partir da bomba é conectada uma mangueira cristal (diâmetro de $3 / 4$ in). Na saída do poço é conectada uma mangueira espiraflex trançada de nylon ( $3 / 4$ in) e nesta foi conectada uma mangueira de polipropileno branco ( $1 / 4$ in) para amostragem na célula de fluxo. Na Figura 11 pode-se observar o arranjo utilizado. Os cabos pretos são dos transdutores de pressão e de conexão elétrica.

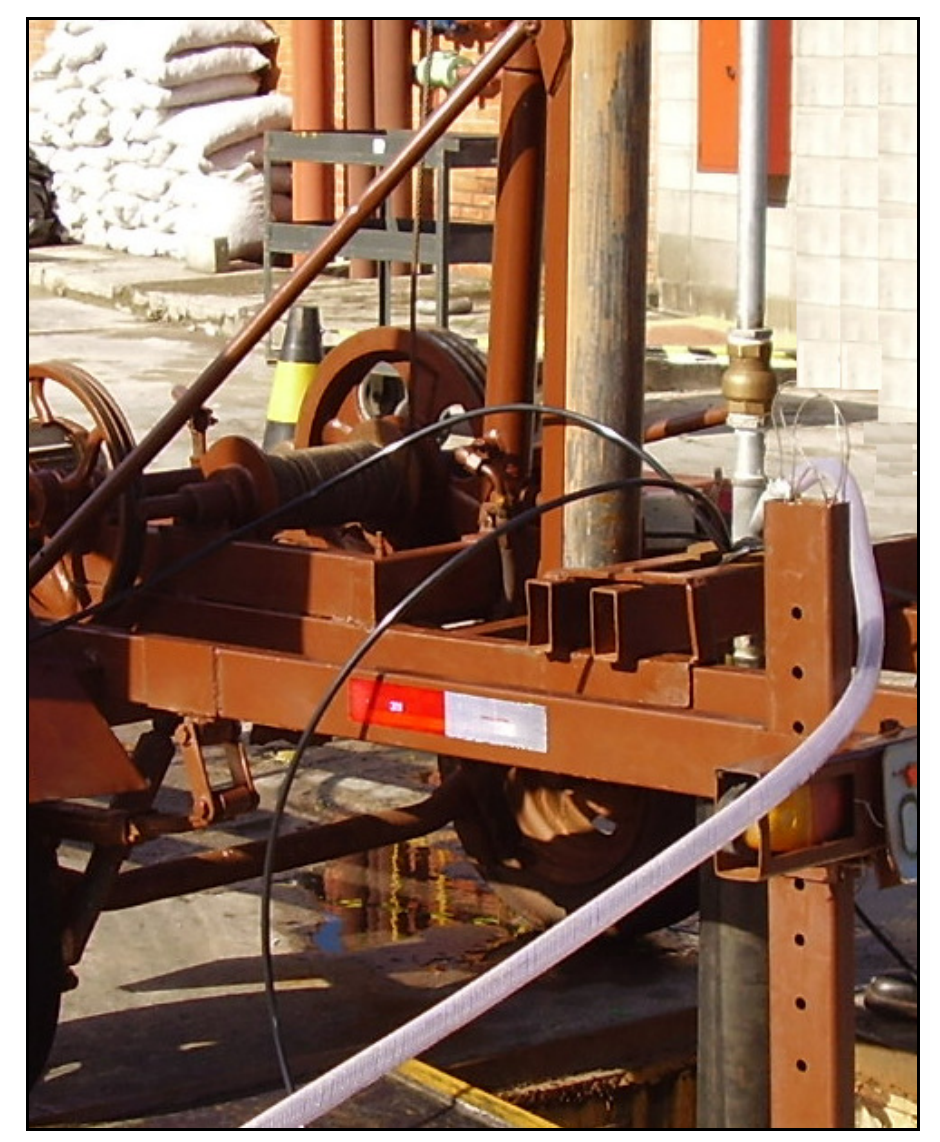

Figura 11- Arranjo utilizado na operação de ensaios com obturadores.

O tubo de aço de 1,5 in faz a sustentação de todo o equipamento que desce no poço até cerca de $100 \mathrm{~m}$ de profundidade, limite no qual a bomba utilizada nos testes tem boa capacidade de operação.

Os níveis d'água das porções obturadas foram medidos por meio de três transdutores de pressão conectados a um registrador de dados. Um transdutor permanece acima do obturador superior, outro na posição intermediária e o terceiro, abaixo do obturador inferior. Do registrador de dados, as informações são enviadas em tempo real para o computador, permitindo determinar a qualidade do teste durante seu desenvolvimento. 
Para a realização do ensaio foram selecionados os poços que atendessem as seguintes condições necessárias: desativados e sem equipamento; com diâmetro de 6 in; com informações confiáveis de litologia e de revestimento; sem revestimento na porção fraturada; com revestimento na porção inconsolidada; localizados fora da área de influência de outros poços de produção, para não haver influência em seus níveis estáticos; com a possibilidade de entrada e manobra dos equipamentos; com ocorrências de compostos organoclorados.

Devido a complexidades específicas de alguns poços, como porções de argila dificultando obturações, níveis de água profundos e dificuldades de agendamento em indústrias, os ensaios foram efetivamente realizados em quatro poços para serem coletadas 15 amostragens com uso de obturadores: 1502, 1249, 691 e 692.

\subsubsection{Ensaio de bombeamento}

Os ensaios de bombeamento de poços permitem medir diretamente parâmetros hidrodinâmicos do aqüífero ou porção do aqüífero, como a transmissividade $(T)$, a condutividade hidráulica $(\mathrm{K})$. Consistem em bombear um poço a uma vazão constante, acompanhar a evolução dos rebaixamentos produzidos no poço bombeado e, em um ou mais poços de observação (Figura 12). Após o término do bombeamento é feito o registro da recuperação do nível da água no poço bombeado e no poço de observação. As variáveis medidas, em determinados intervalos de tempo, são: vazão e rebaixamento.

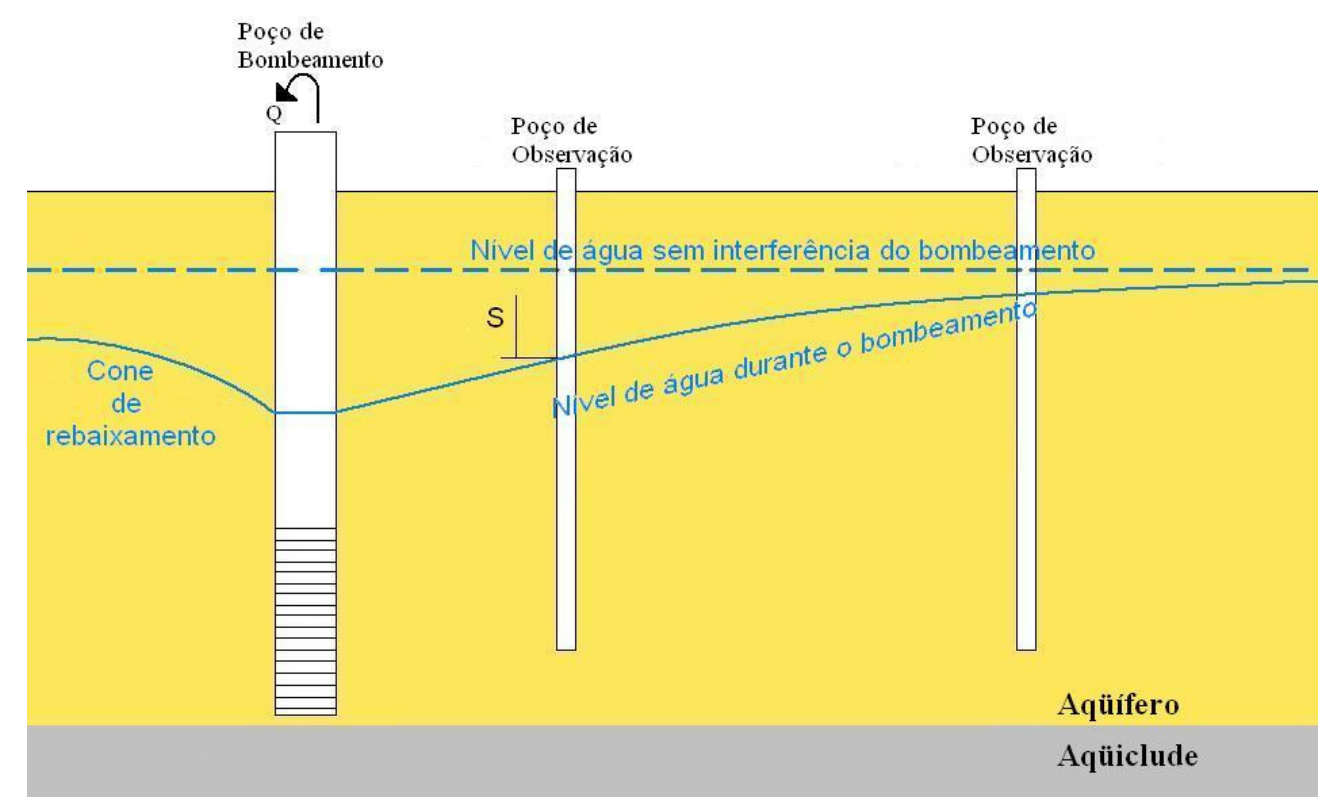

$Q=$ Vazão do poço

Fonte: modificado de Kruseman e Ridder (1991)

$\mathrm{S}=$ rebaixamento do nível da água

Figura 12 - Rebaixamento em aqüífero bombeado. 
Durante a execução dos ensaios, a vazão foi controlada com o registro instalado no poço e medida por hidrômetro mecânico, sendo checada no início em comparação com um balde graduado de $20 \mathrm{~L}$.

Os equipamentos utilizados são: medidores elétricos de nível de água (com extensão de $200 \mathrm{~m}$ ), utilizados no poço bombeado e no poço observado, respectivamente; cronômetro; registro e hidrômetro mecânico; bomba submersa (equipamento do próprio poço); balde de 20 L; mangueiras de PVC 1 in, espiraflex trançada de nylon de $3 / 4$ in e mangueira para amostragem de polipropileno branco de $1 / 4$ in.

\subsection{Coleta de Amostras para Análises Químicas}

Além das análises químicas preexistentes, obtidas na fase de levantamento de dados e com os usuários durante as visitações aos poços, foram realizadas, no contexto do projeto DAEE-Servmar, 25 análises químicas, em 9 poços. Foram analisados os parâmetros relacionados nas tabelas 1,3 e 5 da Portaria 518 (exceto microcistinas) e a varredura complementar de compostos orgânicos semi-voláteis e voláteis que constam da lista dos Valores Orientadores (CETESB, 2005).

Entre todos os parâmetros analisados, o projeto de mestrado foca apenas os resultados de etenos e etanos clorados, o grupo de compostos com maior freqüência de ocorrência nos poços de produção e refletem uma contaminação de caráter regional na área de estudos.

Foram adotadas três formas de coleta: amostragem simples, escalonada e com obturadores. As amostragens simples e escalonada foram realizadas em poços localizados no entorno da área de restrição temporária; a amostragem com obturadores, dentro da área de restrição temporária.

O cumprimento de procedimentos adequados e padronizados na coleta de amostras de água é fundamental para a confiabilidade nos resultados e num eficiente programa de monitoramento da qualidade da água. Assim, foram observados os critérios de plano de amostragem da norma CETESB 6410: "Amostragem e monitoramento das águas subterrâneas", incluindo as metodologias adequadas para coleta, preservação e encaminhamento das amostras.

Para garantir a representatividade do aqüífero pelas amostras coletadas, foram monitorados parâmetros físico-químicos com uma célula de fluxo (QED MP20), prosseguindo com a coleta de água após estabilização desses parâmetros. Foram medidos: temperatura, oxigênio dissolvido, potencial de óxido-redução e condutividade elétrica. A célula de fluxo foi 
conectada, para a amostragem, a uma mangueira de polipropileno branco ( $1 / 4 \mathrm{in})$, e esta, a uma mangueira espiraflex trançada de nylon ( $3 / 4$ in) ligada no poço. A estabilização do nível d'água e dos parâmetros indicadores é utilizada para determinar o momento em que a água da formação é acessada, eliminando a possibilidade de coleta de água estagnada no poço.

O acondicionamento de amostras foi feito com frascos perfeitamente limpos, armazenados corretamente e apropriados para o tipo de análise em termos de volume e material do frasco (orgânicos, frascos de vidro; inorgânicos, frascos de polietileno).

$\mathrm{Na}$ amostragem simples buscou-se pontos preferencialmente próximos aos limites, para identificar possíveis comprovações de contaminação, fora da área já monitorada (uma vez que os dados de análises químicas preexistentes eram de dentro da área de restrição temporária). $\mathrm{Na}$ amostragem com obturadores buscou-se um detalhamento vertical das ocorrências.

A amostragem simples, feita em poços equipados e bem construídos, explorando apenas o aqüífero cristalino, teve o objetivo de caracterizar a qualidade das águas de arredores imediatos ao poço e preferencialmente da zona mais superficial do aqüífero, pois são as águas que chegam rapidamente logo no início do bombeamento do poço.

Nesta etapa foram amostrados três poços: poço 362, em área contaminada declarada pela CETESB, ao sul da área de restrição temporária; poço 61, área hospitalar localizada ao norte da área de restrição temporária e numa área com alta densidade de poços e, poço 1591, dentro de uma indústria, localizado a noroeste da área de restrição temporária, também em área com alta densidade de poços. A localização destes poços está apresentada na Figura 8.

A amostragem escalonada foi realizada durante os testes de bombeamento para observar a variação de concentração em função da localização e tempo de trânsito da água. Esta coleta de amostras foi realizada nos poços 195, 1618 e 748. Neste caso, o procedimento de coleta obedeceu os mesmos procedimentos aplicados na amostragem simples, com conexão da saída de água do poço através de mangueiras à célula de fluxo.

Foram coletadas: no poço 195, uma amostra após três horas de bombeamento; no poço 1618, três amostras, após 2, 6 e 24 horas de bombeamento e, no poço 748, três amostras, após 2, 6 e 24 horas de bombeamento.

A amostragem de água com os obturadores em diferentes porções do aqüífero, ou em determinada fratura, foi realizada nos poços 691,692 e 1249, possibilitando a coleta de amostras em diferentes profundidades num mesmo poço. A coleta da água foi realizada após a estabilização dos níveis de água sob um bombeamento com vazão controlada e a estabilização dos parâmetros físico-químicos. O número de amostras em cada poço foi distinto, conforme o bom resultado de obturação em diferentes profundidades, sem ocorrência de vazamentos. 


\subsection{Tratamento e Interpretação de Resultados}

As metodologias de tratamento de dados hidrológicos e de elaboração de modelos conceituais hidrogeológicos foram baseadas, principalmente, nos trabalhos de Bertolo (1996) e DAEE (1975). As metodologias para a avaliação de vulnerabilidade de aqüíferos foram baseadas em Hirata et al (1997) e Foster et al (2007). Em geral, as informações foram trabalhadas digitalmente em planilhas, gráficos, figuras e mapas georreferenciados.

Com o cadastro de poços, inicialmente, foram realizados trabalhos de homogeneização e unificação de cadastros preexistentes e de eliminação de duplicidade de informações. Posteriormente, foram feitas a análise e a consistência de dados e o cadastro foi organizado de maneira a permitir priorizar o trabalho sobre as informações confiáveis e mais importantes, isolando informações dispensáveis.

A base cartográfica principal, utilizada no trabalho, foi construída em Sistema de Informações Geográficas (SIG), constituída de hidrografia e ocupação industrial.

Com o desenvolvimento do trabalho foram gerados diversos mapas de apresentação de resultados e foram executados exercícios variados de cruzamento de informações. A rede de poços foi representada no mapa utilizando-se os dados de coordenadas de poços e, os demais dados do cadastro puderam ser visualizados espacialmente, por exemplo: o cruzamento de dado de ocorrência de contaminação versus distribuição de áreas industriais.

Pôde-se verificar a existência e a localização de perfis litológicos e construtivos que embasaram o modelo conceitual geológico além de trabalhar o cruzamento de dados como: data de perfuração, nível estático, uso do poço, cota topográfica, vazão de outorga, etc. Com esta informações, pôde-se produzir mapas de potenciometria de diferentes períodos, com vistas à verificação de rebaixamentos excessivos do nível de água. Os dados de vazão dos poços e a finalidade do uso da água subsidiaram informações sobre as características locais de uso da água.

A interpretação da geologia para determinar a geometria das unidades aqüíferas incluiu a avaliação dos perfis geológicos em relatório de poços, identificando a espessura das camadas sedimentares, das de intemperismo e das da rocha cristalina sã; a separação de poços segundo suas profundidades, litologia atingida e posicionamentos de filtros (consideração de parâmetros hidrogeológicos obtidos em ensaios preexistentes e ensaios executados).

A separação dos poços segundo data de construção permitiu verificar a potenciometria local em diferentes épocas. A definição de um modelo conceitual hidrogeológico é o caminho para o reconhecimento do fluxo de águas subterrâneas, como um indicativo do processo advectivo no transporte de contaminantes. 
Os aspectos de qualidade do solo foram definidos conforme as características de uso e ocupação do solo por indústrias, as condições de contaminação do subsolo conhecidas dos processos de Áreas Contaminadas Declaradas da CETESB e as ocorrências de organoclorados em poços de produção.

As cargas contaminantes foram classificadas com o método POSH (Foster et al, 2007) e o cruzamento das fontes potenciais de poluição com o mapa de vulnerabilidade GOD (Foster et al, 2007) permite definir as áreas prioritárias ou suspeitas de contaminação.

A quase totalidade dos resultados de análises químicas estava disponível em vias impressas e os resultados foram digitalizados em planilhas.

Os dados das fichas de áreas declaradas contaminadas foram postos em uma planilha e foram gerados gráficos para visualizar as proporções de ocorrências de características das áreas, tais como: tipo de área, grupo contaminante, fonte de contaminação, etapa de gerenciamento, etc.

A integração das características gerais da área e suas bases cartográficas, o conhecimento da quantidade relativa de água subterrânea explorada e a caracterização da qualidade das águas subterrâneas, permitem estabelecer as áreas de restrição e controle, bem como sugerir medidas de controle de uso do recurso hídrico subterrâneo.

Para a definição de medidas de restrição e controle, foi realizada uma análise da situação frente à legislação incidente sobre o uso dos recursos hídricos subterrâneos em área crítica, devido à ocorrência de contaminação. 


\section{USO DA ÁGUA SUBTERRÂNEA}

$\mathrm{Na}$ área de estudo existem 513 poços outorgados no DAEE (Figura 13), mas segundo estimativas apontadas no Plano da BAT (FUSP, 2002) apenas 30\% de poços são outorgados. Assim, sabe-se que o número de poços de produção existente na área é muito maior.

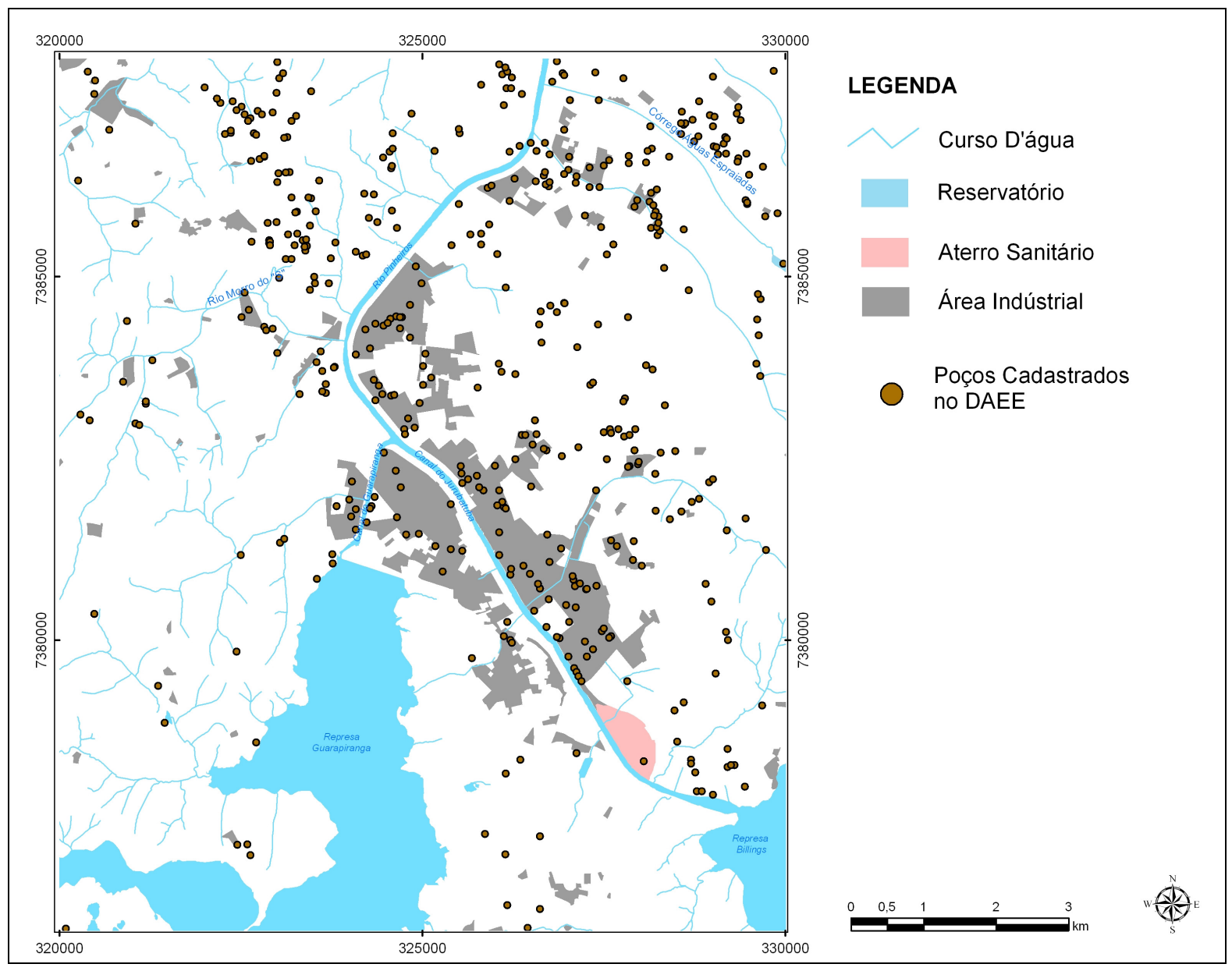

Figura 13 - Rede de poços outorgados.

O cadastro de poços (Anexo I) foi trabalhado de maneira a eliminar duplicidades e avaliar a consistência dos dados. Os principais dados dos poços, tais como, identificação do poço, endereço, proprietário, coordenada geográfica, profundidade, nível d'água, data de perfuração, uso, cota topográfica, vazão de outorga, perfil litológico, perfil construtivo, entre outros, foram a base para o entendimento da hidrologia local.

Conforme o cadastro de poços, na área de estudo, 257 poços (50\%) estão ativos, 68 (13\%) estão desativados, 17 (4\%) lacrados e 10 (2\%) tamponados. Para os demais 157 poços (31\%) não há informação do estado do poço. 
Dentre os 513 poços cadastrados, o maior número de poços (320) não apresenta informações litológicas ou construtivas que permitem definir qual o aqüífero explorado. Entre os poços com esta informação (193), a maior parte (120) explora o aqüífero Cristalino (Figura 14).

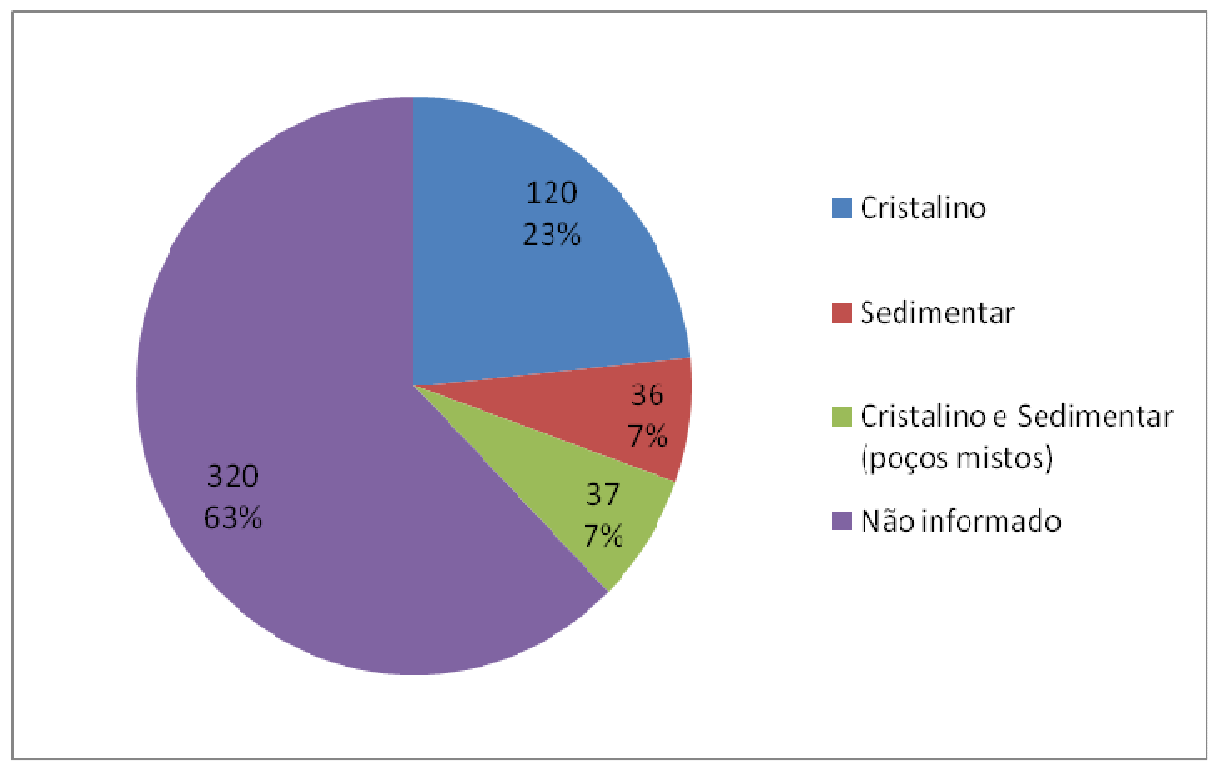

Figura 14 - Sistema aqüífero explorado por poço.

Sobretudo nas décadas de 90 e 2000 houve aumento do número de poços na região (Figura 15), fato que interferiu na potenciometria da área.

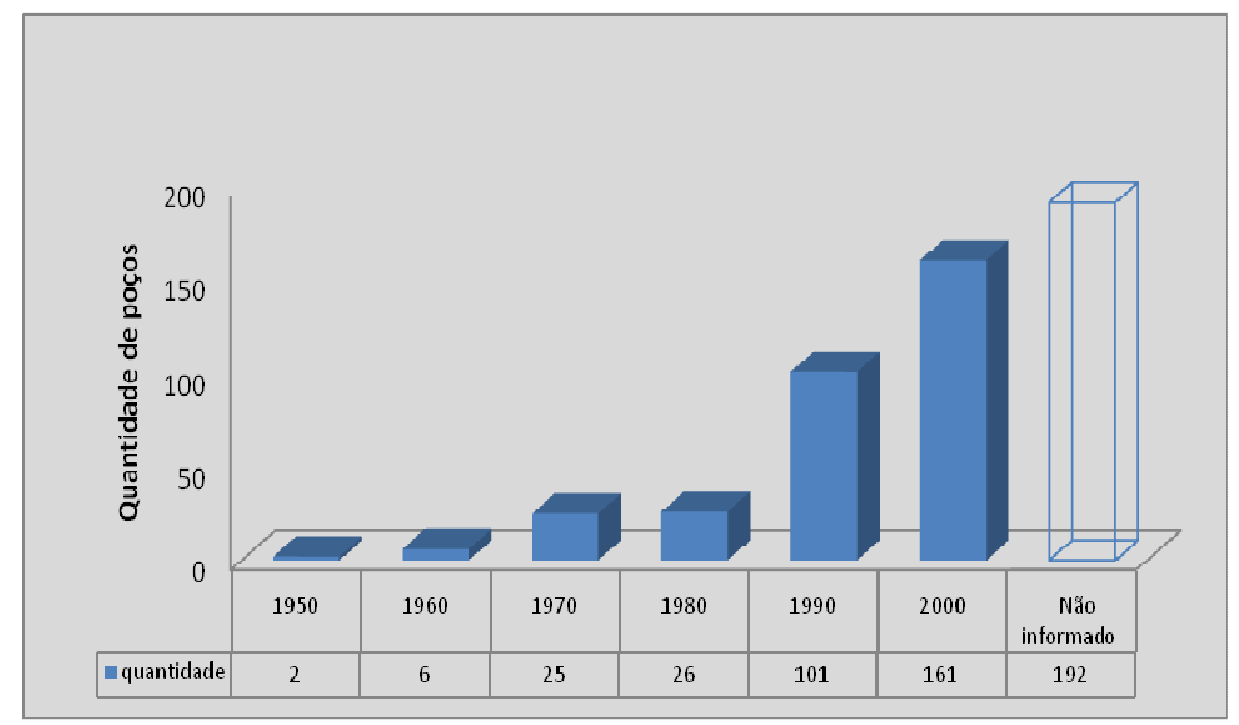

Figura 15 - Evolução de número de poços construídos por décadas. 


\subsection{Condições de Estrutura e Manutenção dos Poços}

É previsto pela Lei 6.134 de 1988 (Decreto 32.955/1991), no Capítulo III, Seção V, que não deve haver qualquer atividade no entorno do poço num raio mínimo de $10 \mathrm{~m}$, a partir do ponto de captação, para resguardar a entrada ou penetração de poluentes. A visita a poços em campo permitiu verificar uma situação inadequada de estrutura e manutenção de poços, possivelmente associada à falta de conscientização sobre a importância e a vulnerabilidade do recurso hídrico subterrâneo. Em campo, foram vistos 82 poços, sendo que apenas um apresentou perímetro de proteção de 10 m, 12 não tinham laje de proteção de concreto e 10 estavam sem tampa.

Em campo, além da ocorrência de tampas vedando parcialmente a entrada do poço e ausência de laje de proteção sanitária, foi observada a existência de resíduos sólidos no entorno ou em cima do poço, poços desativados e sem tamponamento em área de indústria desativada, oxidação de tubos e tampa. A Figura 16 apresenta situações de poços em bom e mau estado de estrutura ou manutenção.

Outro sério problema com relação à utilização de poços de produção é o mecanismo de desativação de um poço. Em campo foi observada uma situação de três poços abandonados com todo o equipamento de bombeamento instalado. Um dos poços está soterrado sob uma loja de eletrônicos, sem terem sido aplicadas quaisquer medidas para o seu tamponamento e desativação. Cabe lembrar que estes poços representam zonas de conectividade entre os diversos horizontes do aqüífero. 


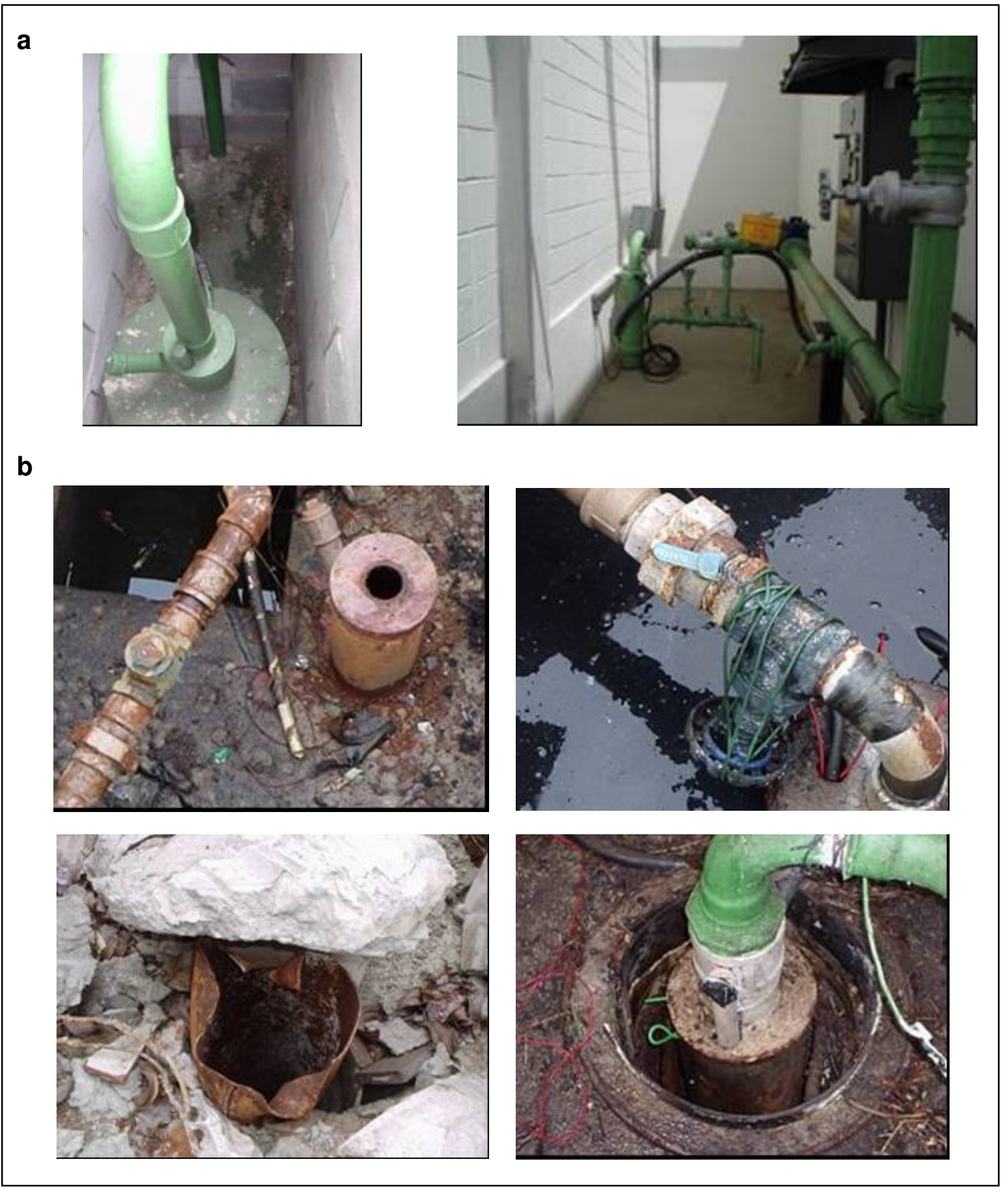

Figura 16 - Exemplos de poços em bom estado de conservação (a) e de poços mau conservados (b), observados em campo 


\subsection{Quantidade de Água Explorada}

Os dados de vazão existentes no cadastro (Anexo I) são de vazão de outorga. Para estimar a vazão de exploração foi necessário assumir a vazão de outorga como a vazão explorada durante uma carga horária no dia. A informação do cadastro é apresentada em duas colunas, a primeira com os dados de vazão $\mathrm{em}^{3} / \mathrm{h}$ e a segunda com o número de horas por dia. Nem todos os poços têm estas informações.

A carga horária de outorga média, obtida de 317 poços com esta informação, é de 14 $\mathrm{h} /$ dia. A vazão total somada de 321 poços com conhecimento de vazão é $2.560 \mathrm{~m}^{3} / \mathrm{h}$, ou seja, 8 $\mathrm{m}^{3} / \mathrm{h}$ em média. Isto resulta numa estimativa de $35.950 \mathrm{~m}^{3} /$ dia.

A soma da vazão de outorga multiplicada pelas horas de exploração, referente aos 306 poços que fornecem esses dados concomitantemente, ou seja, com os cálculos realizados aplicando-se a carga horária e vazão específicas de cada poço e somadas posteriormente, resultou em $33.680 \mathrm{~m}^{3} /$ dia, corroborando com o cálculo acima e, portanto, dando segurança para assumir uma exploração média de $8 \mathrm{~m}^{3} / \mathrm{h}$ a $14 \mathrm{~h} /$ dia para os demais 192 poços, obtendose uma vazão de $21.505 \mathrm{~m}^{3} /$ dia.

Enfim, uma estimativa total de vazão considerando 513 poços explorando $8 \mathrm{~m}^{3} / \mathrm{h}$ a 14 $\mathrm{h} /$ dia, resulta em $57.455 \mathrm{~m}^{3} /$ dia. Vale lembrar que esta estimativa considera apenas os poços outorgados e a vazão total de água subterrânea pode variar, proporcionalmente, em relação ao número de poços desconhecidos. Caso os poços outorgados representem, por exemplo, $50 \%$ do total de poços, esta estimativa de vazão poderia ser dobrada.

A Figura 17 apresenta a informação do número de poços por cada setor usuário, conhecida em 437 poços. Grande parte dos poços é para o uso doméstico (40,4\%), seguido, do uso industrial (processo e sanitário), com 31\%. No entanto, em termos de vazão esta relação se inverte: a atividade industrial (processo e sanitário) é a maior usuária de água $(39,5 \%)$, seguida do uso doméstico (34,4\%).

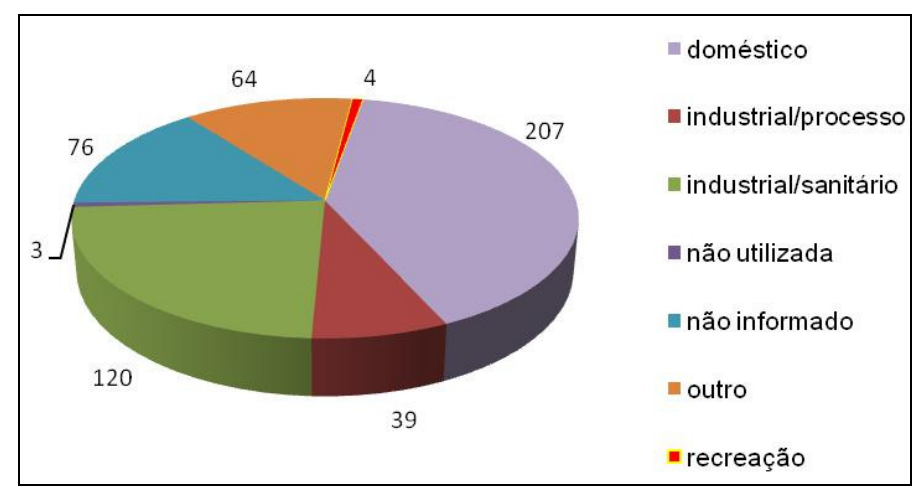

Figura 17 - Distribuição do número de poços em relação ao tipo de uso de água. 
Considerando os poços com informações de vazão (323 poços), observa-se que 167 (52\%) apresentam as menores vazões, de até $5 \mathrm{~m}^{3} / \mathrm{h}$. (Figura 18).

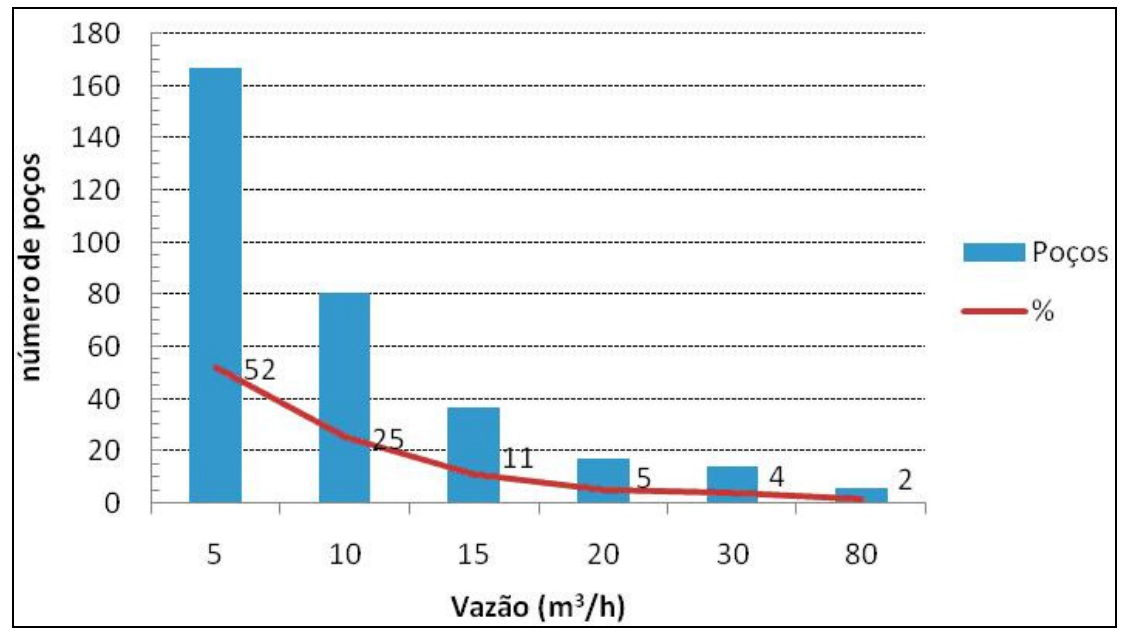

Figura 18 - Número de poços e vazão de outorga na área de estudo

A distribuição de vazão por poços é apresentada na Figura 19, permitindo identificar os poços com maior vazão em área predominantemente industrial.

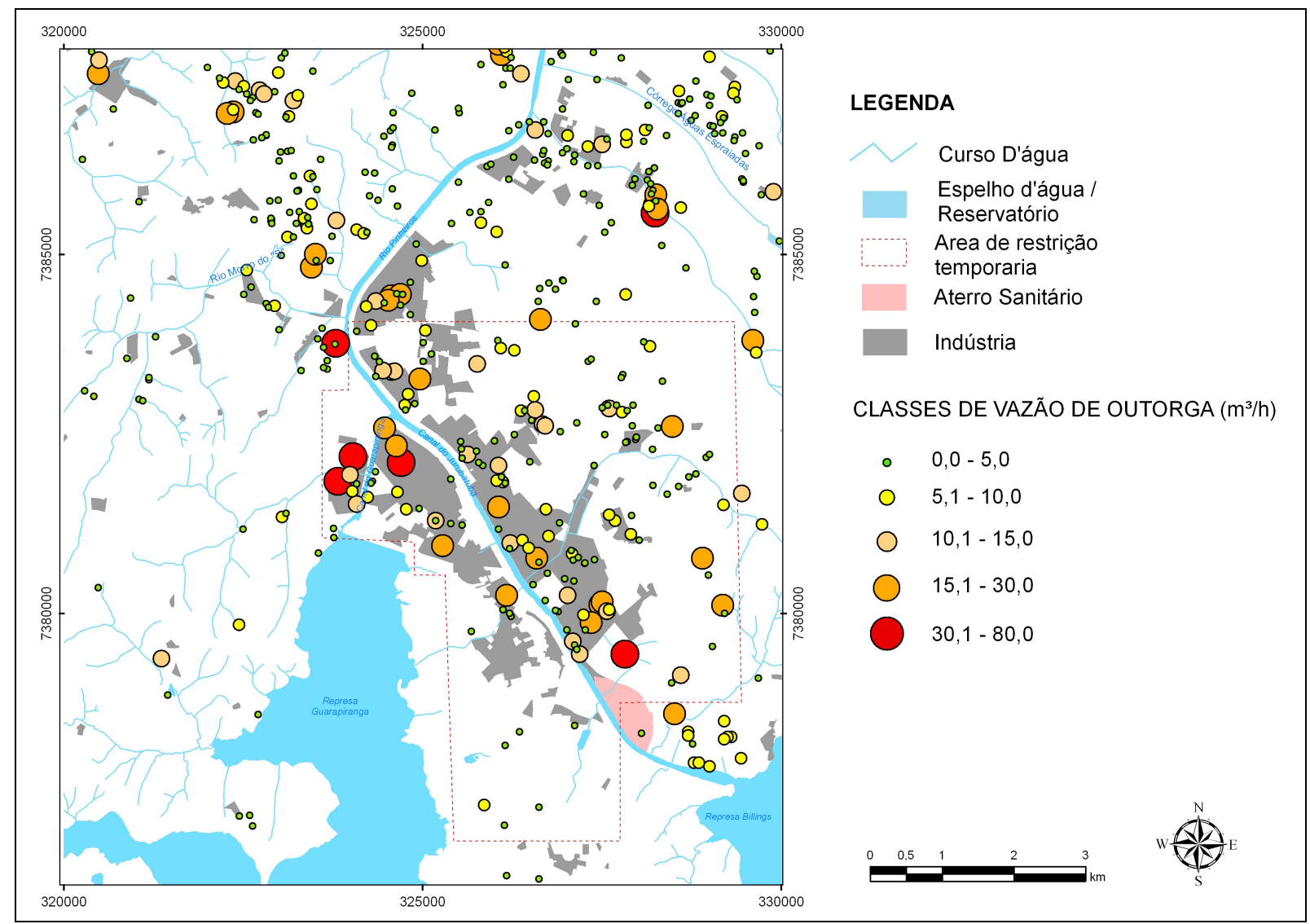

Figura 19 - Vazão de outorga dos poços 


\section{MODELO CONCEITUAL HIDROGEOLÓGICO}

\subsection{Geologia Estrutural Aplicada à Hidrogeologia}

\subsubsection{Descrição geológico-estrutural}

A natureza estrutural do terreno na área de estudos, constituída de um aqüífero fraturado em parte recoberto por um aqüífero sedimentar, é determinante para a compreensão e concepção de um modelo hidrogeológico conceitual.

Com base em descrições litológicas dos poços, existentes no cadastro de poços, foram discretizados os três meios com diferentes características hidráulicas: o meio sedimentar, referente ao aqüífero Sedimentar, na parte superior; a rocha alterada em posição intermediária e, a rocha sã, na base, referentes ao aqüífero Cristalino.

Conforme o DAEE (1975), o aqüífero Cristalino é formado por duas unidades hidrogeológicas características. A primeira, o aqüífero do manto de intemperismo, de natureza livre, heterogêneo e anisotrópico, com porosidade intergranular. A segunda, o aqüífero cristalino propriamente dito, onde a água circula através dos lineamentos estruturais como falhamentos, juntas associadas e fraturas abertas da rocha sã, caracterizando o aqüífero como livre a semilivre, heterogêneo e anisotrópico.

Rocha et al (1989) observou, em relação ao aqüífero cristalino, um sistema aqüífero mais extenso, correspondente ao manto de alteração das rochas cristalinas pré-cambrianas. As espessuras são bem desenvolvidas, podendo atingir uma centena de metros. A zona de transição da rocha sã, normalmente, apresenta permeabilidades mais elevadas.

O pacote sedimentar é muito heterogêneo, apresentando lentes ou camadas descontínuas de areias grossas, médias e finas, intercaladas com corpos argilosos ou formando misturas em proporções variadas (Rocha, 1989). O aqüífero Sedimentar possui espessuras maiores do que 100 m., na porção leste da área de estudo.

O aqüífero Cristalino aflora na porção oeste da área, configurando uma topografia irregular, relacionada à maior resistência ao aplainamento, característica das rochas ígneas e, à ocorrência de falhas, associadas à reativação de antigas zonas de cisalhamento do embasamento. Segundo Rocha (1989), a topografia do substrato cristalino apresenta-se acidentada na forma de horts e grabens, originando sub-bacias, janelas e ramificações laterais. $\mathrm{Na}$ porção leste, o aqüífero Cristalino apresenta-se sob os sedimentos da bacia e a camada alterada da rocha cristalina possui espessura variável de $10 \mathrm{~m}$ até $70 \mathrm{~m}$. 
As seções geológicas traçadas na área de estudo permitiram observar o comportamento das camadas sedimentares e cristalinas identificando alguns blocos basculados com desníveis verticais de origem tectônica. Esses basculamentos podem ser estruturas rúpteis de falhas normais ou inversas (Figura 20).

As seções E - E' e K - K' mostram feições possivelmente associadas aos basculamentos de blocos descritos em estudos sobre a geologia da área (Rocha et al, 1989; Riccomini, 1989; Riccomini; Coimbra; Takiya, 1992; Juliani, 1992).

Pode-se observar espessuras de sedimentos variando desde unidades de metros a até cerca de $100 \mathrm{~m}$. As espessuras de rocha cristalina alterada variam de unidades de metros até cerca de $50 \mathrm{~m}$. Na seção D - D', optou-se por ilustrar uma interpretação de um topo do cristalino variando a cota como uma característica de paleo-relevo, entretanto, estas variações de topo também podem estar associadas a basculamentos.

\subsubsection{Tratamento e interpretação de dados geológico-estruturais}

O detalhamento da geologia estrutural, realizado com o imageamento acústico de seis poços $(691,692,1501,1502,1503$ e 1249), permitiu verificar estruturas como xistosidades, bandamentos e fraturas, ocasionalmente representativas das falhas que controlam o fluxo da água no aqüífero Cristalino.

A verificação dessas estruturas orientou o posicionamento de obturadores para a definição de sentidos de fluxo e amostragens de água em trechos isolados de poços.

Os compartimentos estruturais observados ao longo do perfil do poço foram investigados, principalmente, sob as seguintes ocorrências ou características:

- trends direcionais de fraturas;

- mergulhos de fraturas;

- paralelismo ou discordância das fraturas com relação à xistosidade ou bandamento;

- densidade do fraturamento. 

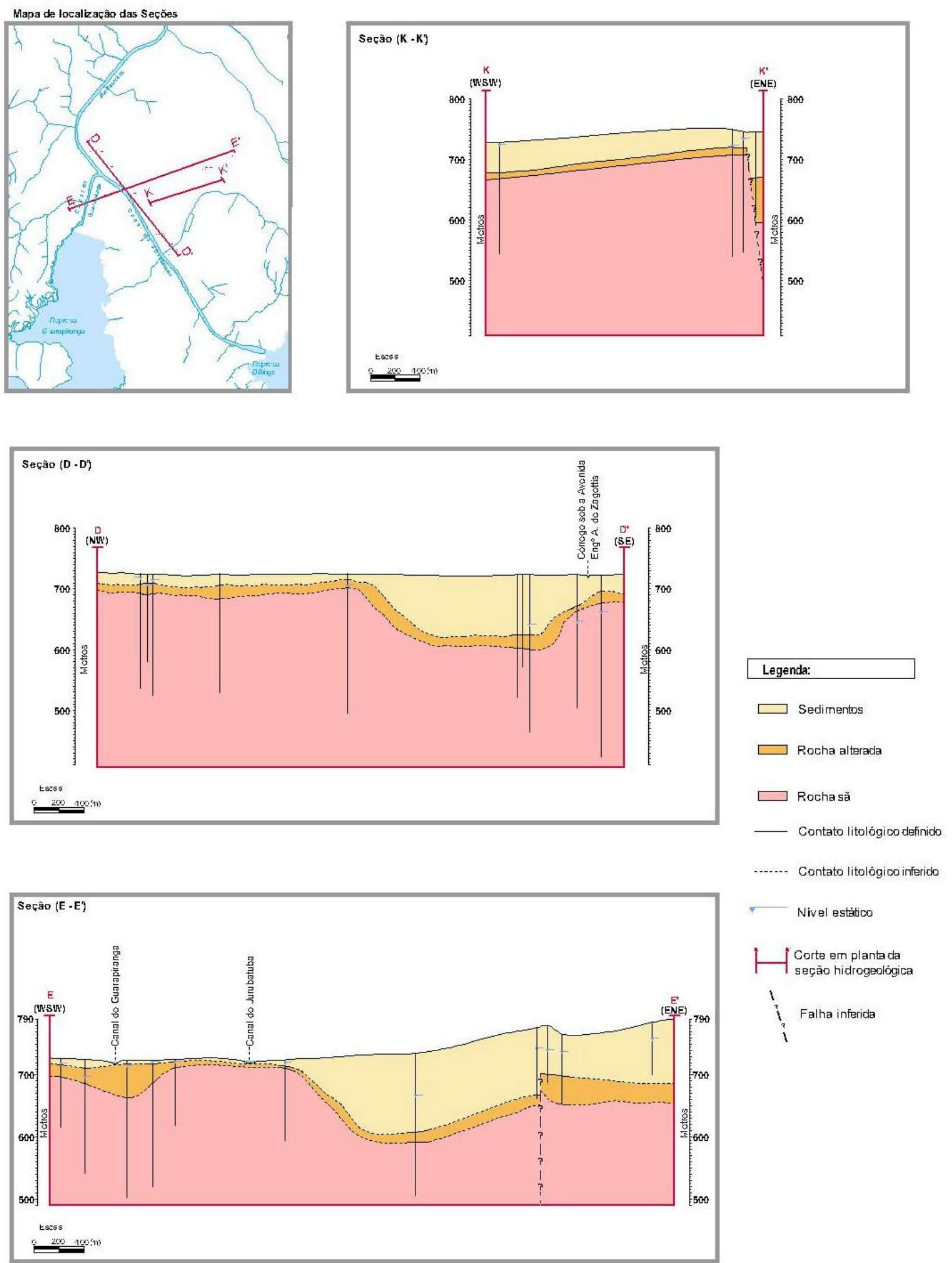

Figura 20 - Seções Geológicas 
As fraturas foram identificadas por feições associadas a alterações da rocha a partir das superfícies de fraturas. Estas feições apresentaram espessuras de $1 \mathrm{~mm}$ até $10 \mathrm{~cm}$ que podem indicar relações de maior ou menor abertura, porém não permitindo definir tamanhos de abertura.

Associando-se o imageamento acústico a descrições de perfis litológicos, foi possível observar vários tipos de texturas: xistosa, foliada, maciça e bandada. A xistosidade, presente nos trechos de textura xistosa, caracteriza-se por grande variabilidade de direções, mas os mergulhos, em geral, são baixos, variando de $10^{\circ}$ a $50^{\circ}$.

Em geral, nos trechos mais superficiais de cada poço há um predomínio de fraturas paralelas à xistosidade e, conseqüentemente, de baixo ângulo. No trecho inferior de cada poço, os mergulhos das fraturas tendem a ser intermediários (45 a $\left.65^{\circ}\right)$ a elevados $\left(60^{\circ}\right.$ a $\left.90^{\circ}\right)$, no entanto, também se observam fraturas de baixo ângulo. Este predomínio de fraturas de baixo ângulo, na porção rasa e, de maior ângulo, na porção mais profunda, apresentou-se mais evidente no Poço 692, como pode ser observado na Figura 21.

Poço 692 - Fraturas

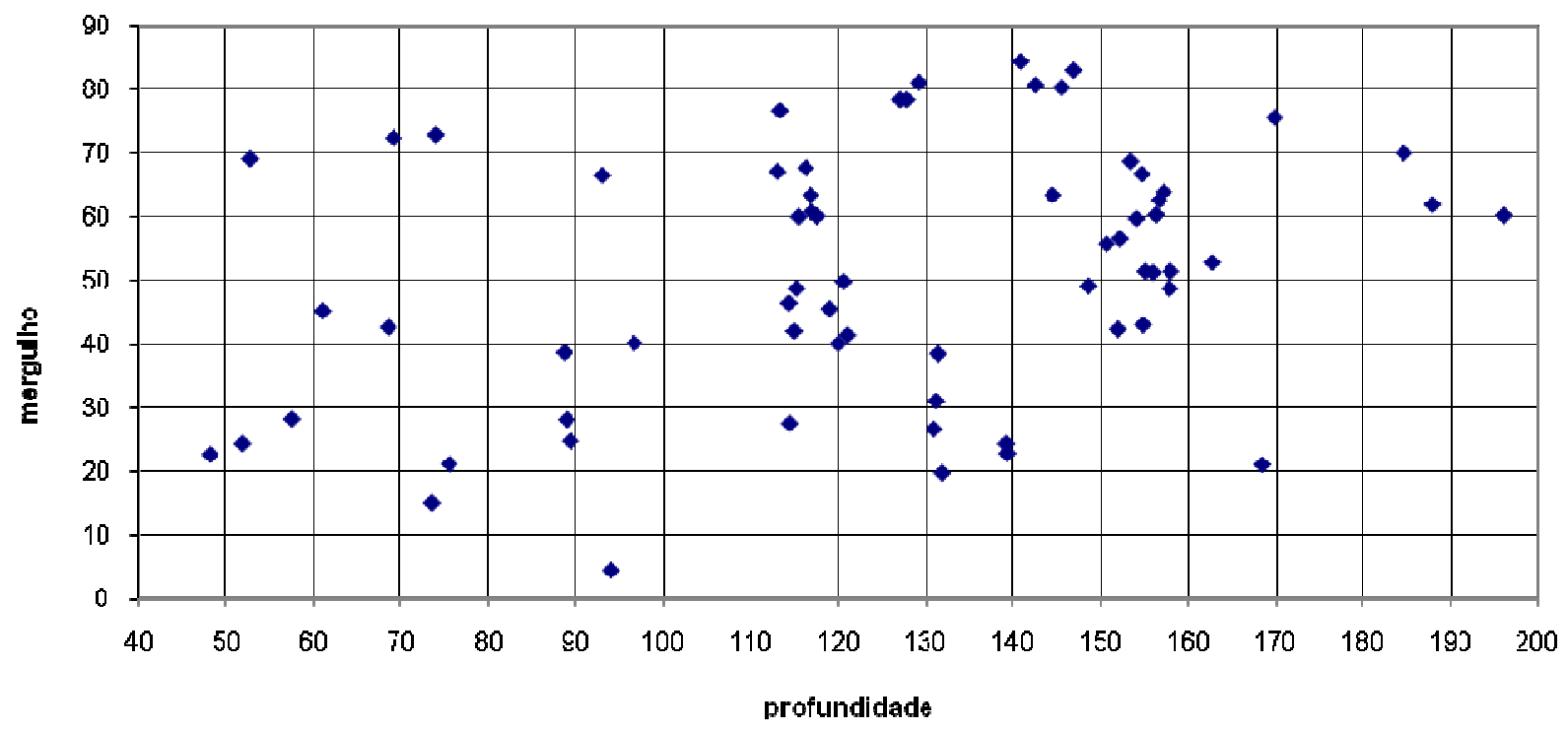

Figura 21 - Gráfico indicando as fraturas de maior ângulo, que predominam em maiores profundidades no poço 692

Nos poços 691, 1502 e 1503, também ocorre um predomínio de fraturas de baixo ângulo na porção rasa e de maior ângulo na porção mais profunda; no poço 1249, foram observadas fraturas apenas nas porções mais rasas, também com baixos mergulhos; no poço 1501, foram obtidos dados apenas após os $80 \mathrm{~m}$ de profundidade e, foram observadas fraturas com mergulhos médios ao longo de todo o trecho perfilado. 
Deve-se considerar que, próximo à superfície, o alívio de carga tende a destacar ou formar fraturas de baixo ângulo, a serem formadas, preferencialmente, ao longo das estruturas mais antigas, ou seja, dos planos de foliação, xistosidade ou bandamento. De acordo com essas informações, em termos hidráulicos, isto pode implicar em que, nas porções mais rasas, o fluxo se dê, preferencialmente, ao longo dessas estruturas de ângulo baixo, implicando em uma anisotropia para o aqüífero fraturado neste setor. Assim, os contaminantes tendem a ser transportados para distâncias mais longas na horizontal, tendendo a acompanhar o mergulho dessas estruturas mais antigas. Por este motivo, o conhecimento dos trends destas estruturas e de sua variação também é importante, podendo influenciar na anisotropia de fluxo. Em contraponto a esta observação, tem-se os poços servem de canalização vertical, interligando as zonas superiores às inferiores do aqüífero.

Um aspecto estrutural importante, favorável a um incremento no fluxo de água, é a bimodalidade dos mergulhos e direções observadas nos poços 691 (entre $110 \mathrm{~m}$ e $125 \mathrm{~m}$ ocorrem mergulhos de 10 a $30^{\circ}$ e de 50 a $75^{\circ}$ ) e 692 (entre 130 e 180m ocorrem mergulhos de 10 a $30^{\circ}$ e de 50 a $70^{\circ}$ ). Isto deve propiciar melhores condições para a circulação da água, pois, provavelmente, possibilita uma maior quantidade de intersecções de fraturas.

Os poços 691 e 692 apresentaram a compartimentação tectônica mais evidente dentre os quatro poços testados com obturadores, especialmente o poço 691. Em função disso, estes poços foram priorizados para a aplicação de testes com obturadores, detalhados no próximo item, buscando testar as seguintes grandes compartimentações:

- Teste 691_51,4 m para cima, abrangendo, principalmente, fraturas NE;

- Teste 691_95,3 m para baixo, abrangendo fraturas NE e NW;

- Teste 691_110,5 para baixo, abrangendo, principalmente, fraturas NW.

O maior detalhamento de dados estruturais, com levantamentos de atitudes de fraturas, é de grande valia para o conhecimento do comportamento dos fluxos de água no aqüífero cristalino. O comportamento de estruturas existentes pode ser compreendido em sua associação com eventos tectônicos antigos e recentes e este entendimento permite associar as fraturas de eventos recentes a uma maior representatividade para o fluxo de água. 


\subsection{Ensaios Hidrodinâmicos}

\subsubsection{Ensaios com obturadores}

O uso de obturadores pneumáticos, realizado em quatro poços instalados no aqüífero Cristalino (691, 692, 1249 e 1502), permitiu identificar diferentes sentidos de fluxo nas diferentes porções obturadas (Tabela 3), contribuindo para a compreensão do comportamento hidráulico do aqüífero Cristalino, além de possibilitar a amostragem para análise química em determinados trechos do aqüífero, ao longo do poço.

Os sentidos de fluxo foram determinados pela diferença de carga hidráulica observada acima e abaixo do ponto obturado, após a estabilização dos níveis estáticos de cada trecho. Quando a carga hidráulica de um trecho inferior é maior do que a carga de um trecho superior, o sentido de fluxo indicado é ascendente, quando a carga hidráulica do nível superior é maior do que a carga do nível inferior, o sentido de fluxo indicado é descendente.

\begin{tabular}{|c|c|c|c|}
\hline \multicolumn{3}{|c|}{ Tabela 3 - Cargas e tendências de direção de fluxo das zonas isoladas. } \\
\hline \multirow{4}{*}{ Poço } & Obturação & Trecho obturado (m) & Direção de fluxo \\
\hline \multirow{4}{*}{691} & 1 & 47,3 para cima & Provavelmente descendente \\
\cline { 2 - 4 } & 2 & 51,4 para cima & ascendente \\
\cline { 2 - 4 } & 3 & 96,0 para cima & ascendente \\
\cline { 2 - 4 } & 4 & 95,3 para baixo & ascendente \\
\cline { 2 - 4 } & 5 & 97,1 a 98,2 & ascendente \\
\cline { 2 - 4 } & 6 & 110,5 para baixo & ascendente \\
\cline { 2 - 4 } & 7 & 115,6 a 1 & ascendente \\
\hline \multirow{4}{*}{692} & 1 & 48,3 para cima & ascendente \\
\cline { 2 - 4 } & 2 & 95,2 a 96,3 & não conclusivo \\
\cline { 2 - 4 } & 3 & 49,2 para baixo & ascendente \\
\hline \multirow{4}{*}{1249} & 1 & 38,2 para cima & não conclusivo \\
\cline { 2 - 4 } & 2 & 46,0 para baixo & não conclusivo \\
\cline { 2 - 4 } & 3 & 45,0 para cima & não conclusivo \\
\cline { 2 - 4 } & 4 & 87,0 para baixo & descendente \\
\cline { 2 - 4 } & 5 & 119,0 para baixo & descendente \\
\hline 1502 & 1 & 105,6 para cima & Provavelmente descendente \\
\hline
\end{tabular}

Os testes dados como não conclusivos o foram porque, além do nível da água não ter atingido a estabilização, a diferença entre as cargas foram mínimas e, com tendência a se igualarem, não permitindo afirmar sobre o sentido de fluxo. A indicação do momento em que 
ocorre o isolamento é o aumento repentino do nível d'água. Depois deste ponto, cada porção assume sua carga natural. A zona com carga maior pode fornecer água para aquela com carga menor, se esta possuir conexão com fraturas que permita a passagem da água.

A Figura 22 ilustra, para o poço 691, os resultados alcançados com os testes realizados nos poços, onde se observa o perfil construtivo esquemático do poço e o nível d'água, profundidade do tubo de boca, profundidade total e posição dos obturadores para cada teste.

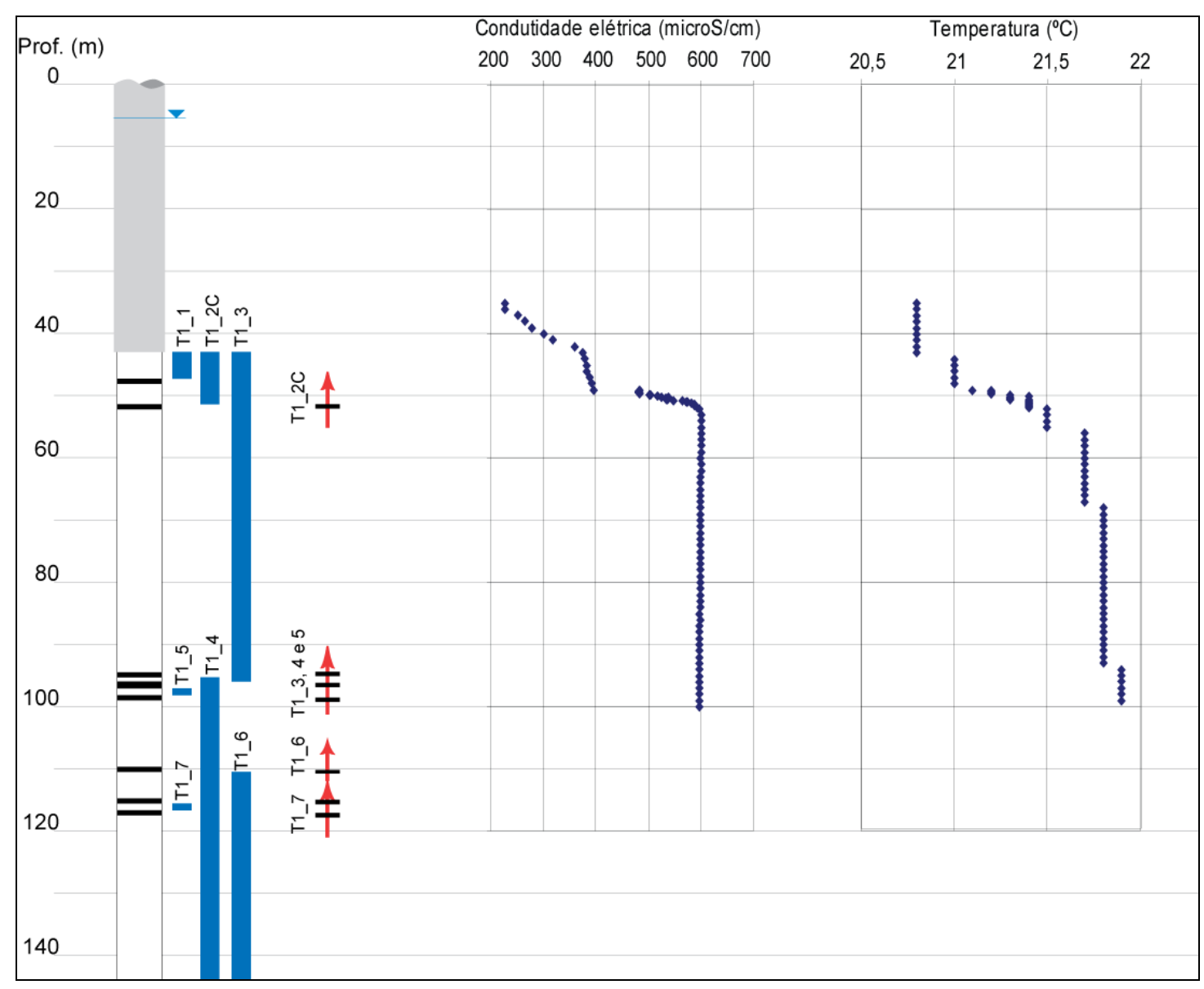

Em azul, têm-se os trechos isolados pela obturação, enumerados de 1 a 7, conforme a seqüência de execução; as barras horizontais, em preto, marcam o posicionamento dos obturadores;

as setas vermelhas apontam o sentido do fluxo da água dentro do poço;

os gráficos ao meio e à direita ilustram valores de temperatura e condutividade, medidos antes da obturação.

Figura 22 - Esquema da obturação no Poço 691

As faixas verticais azuis mostram os intervalos bombeados em cada teste, com as flechas vermelhas indicando a tendência natural do fluxo no poço. Estão apresentadas as perfilagens de condutividade elétrica e de temperatura da água. Esses testes foram realizados até o máximo de $100 \mathrm{~m}$ de profundidade devido à limitação do comprimento dos cabos do equipamento. Os aumentos abruptos da condutividade elétrica e temperatura da água em $43 \mathrm{e}$ $50 \mathrm{~m}$ indicam a presença de feições hidraulicamente ativas nestas profundidades. A porção 
estável da condutividade indica a existência de uma porção de água constantemente homogeneizada, denotando fluxo constante.

\subsubsection{Ensaios de bombeamento}

A interpretação de ensaios de bombeamento de poços cadastrados no DAEE e de ensaios realizados em três poços pela empresa Servmar permitiram medir a condutividade hidráulica $(\mathrm{K})$ e apontar a transmissividade $(\mathrm{T})$ do aqüífero.

Para a rocha alterada, segundo Costa Filho e Vargas Júnior (1985), os valores de condutividade para solos residuais de gnaisses e um migmatito estão, predominantemente, entre $10^{-4}$ e $10^{-3} \mathrm{~cm} / \mathrm{s}$. Segundo DAEE (1975) para o aqüífero Sedimentar são informados valores de transmissividade médios de $50 \mathrm{~m}^{2} / \mathrm{dia}$, variando de 15 a $70 \mathrm{~m}^{2} / \mathrm{dia}$. Assim, o valor médio da condutividade hidráulica é de $0,16 \mathrm{~m} / \mathrm{d}\left(\right.$ ou $\left.1 \times 10^{-4} \mathrm{~cm} / \mathrm{s}\right)$.

O ensaio realizado teve duração de 24 horas e, após o término do bombeamento, foi feito o registro da recuperação do nível por 6 horas, tempo estimado para atingir 95\% do nível d'água original (Kruseman e De Ridder, 1991). O intervalo de medições é apresentado na Tabela 4.

\begin{tabular}{|l|l|}
\hline \multicolumn{2}{|c|}{ Tabela 4 - Intervalos de medição do nível d' água. } \\
\hline \multicolumn{1}{|c|}{ Tempo de bombeamento } & Intervalo entre medições \\
\hline até 2 minutos & a cada $1 \mathrm{~m}$ \\
\hline 3 a 10 minutos & a cada 30 segundos \\
\hline 10 a 60 minutos & a cada 5 minutos \\
\hline 1 a 2 horas & a cada 20 minutos \\
\hline 3 a 24 horas & a cada 1 hora \\
\hline \multicolumn{1}{|c|}{ Tempo de recuperação } & Intervalo entre medições \\
\hline 24 a 30 horas de ensaio & a cada 1 hora \\
\hline
\end{tabular}

Os dados obtidos das variáveis do ensaio foram interpretados através do método de Cooper-Jacob (Feitosa e Filho, 1997), que considera condições de aqüífero confinado não drenante e regime transitório. 
A transmissividade $(T)$ foi obtida de acordo com a equação:

$T=\frac{0,183 Q}{\Delta s} \log \frac{t 2}{t 1}$

onde:

$\mathrm{T}=$ transmissividade $\left(\mathrm{L}^{2} / \mathrm{T}\right)$

$\mathrm{Q}=$ vazão de bombeamento $\left(\mathrm{L}^{3} / \mathrm{T}\right)$

$\Delta \mathrm{S}=$ variação do rebaixamento tomado num ciclo logarítmico $(\mathrm{L})$

$\mathrm{t} 1=$ tempo correspondente ao rebaixamento $\mathrm{s} 1(\mathrm{~T})$

$\mathrm{t} 2=$ tempo correspondente ao rebaixamento $\mathrm{s} 2(\mathrm{~T})$

A condutividade hidráulica $(K)$ foi calculada por:

$K=T \times b$

onde:

$\mathrm{K}=$ condutividade hidráulica $(\mathrm{L} / \mathrm{T})$

$\mathrm{T}=$ transmissividade $\left(\mathrm{L}^{2} / \mathrm{T}\right)$

$b=$ espessura do aqüífero $(L)$

Para realizar os testes de bombeamento foi necessário selecionar os poços sob os seguintes critérios: explorar apenas o aqüífero cristalino; não ter revestimento no cristalino; ter análise de água que não aponta contaminação; ter tubo medidor de nível da água; ter poços próximos, possíveis de serem paralisados para serem utilizados como poços de observação ou para não provocar interferência no teste. A partir destes critérios foi possível realizar três ensaios de bombeamento utilizando os poços 748, 195 e 1618.

Os ensaios de bombeamento permitiram também coletar água para análise química, em diferentes tempos de bombeamento.

Os resultados de ensaios de bombeamento de 24 horas foram obtidos com o método de Cooper-Jacob (Cooper e Jacob 1946, apud, Feitosa e Filho 1997). A condutividade hidráulica média estimada para o aqüífero Cristalino na área de estudo, considerando-se tantos os ensaios realizados no projeto DAEE-Servmar, quanto os ensaios existentes nos autos de poços do DAEE, foi de $7,24 \times 10^{-5} \mathrm{~cm} / \mathrm{s}$ (Tabela 5). 


\begin{tabular}{|l|c|c|c|c|c|}
\hline \multicolumn{7}{|c|}{ Tabela 5 - Parâmetros hidráulicos do aqüífero. } \\
\hline Poço & $\begin{array}{c}\text { Aqüífero } \\
\text { principal }\end{array}$ & Fonte & $\mathbf{T}$ (m2/s) & $\begin{array}{c}\text { Profundidade do } \\
\text { poço } \mathbf{( m )}\end{array}$ & $\mathbf{K}$ (cm/s) \\
\hline 194 & Cristalino & DAEE & $2,52 \mathrm{E}-04$ & 109 & $2,31 \mathrm{E}-04$ \\
\hline 1664 & Cristalino & DAEE & $2,87 \mathrm{E}-06$ & 200 & $1,44 \mathrm{E}-06$ \\
\hline 1619 & Cristalino & DAEE & $1,56 \mathrm{E}-05$ & 146 & $1,07 \mathrm{E}-05$ \\
\hline 1430 & Cristalino & DAEE & $4,44 \mathrm{E}-06$ & 222 & $2,00 \mathrm{E}-06$ \\
\hline 1346 & Cristalino & DAEE & $6,52 \mathrm{E}-06$ & 184 & $3,54 \mathrm{E}-05$ \\
\hline 1683 & Cristalino & DAEE & $7,40 \mathrm{E}-04$ & 150 & $4,98 \mathrm{E}-04$ \\
\hline 386 & indefinido & DAEE & $6,90 \mathrm{E}-06$ & 120 & $5,79 \mathrm{E}-06$ \\
\hline 1481 & Cristalino & DAEE & $7,70 \mathrm{E}-06$ & 180 & $4,28 \mathrm{E}-06$ \\
\hline 1491 & Cristalino & DAEE & $1,22 \mathrm{E}-04$ & 122 & $9,96 \mathrm{E}-05$ \\
\hline 1512 & Cristalino & DAEE & $1,70 \mathrm{E}-06$ & 300 & $5,67 \mathrm{E}-07$ \\
\hline 1635 & Cristalino & DAEE & $2,74 \mathrm{E}-05$ & 150 & $1,83 \mathrm{E}-05$ \\
\hline 1426 & Cristalino & DAEE & $2,77 \mathrm{E}-05$ & 258 & $1,07 \mathrm{E}-05$ \\
\hline 195 & Cristalino & Servmar & $7,33 \mathrm{E}-06$ & 276 & $2,66 \mathrm{E}-06$ \\
\hline 1618 & Cristalino & Servmar & $9,46 \mathrm{E}-06$ & 198 & $4,78 \mathrm{E}-06$ \\
\hline 748 & Cristalino & Servmar & $2,70 \mathrm{E}-04$ & 171 & $1,60 \mathrm{E}-04$ \\
\hline Média & - & - & - & - & $\mathbf{7 , 2 4 E}-05$ \\
\hline
\end{tabular}

\subsection{Modelo Conceitual de Fluxo}

O modelo conceitual de fluxo da água subterrânea para a área de estudo foi elaborado unindo o reconhecimento da hidrogeologia local, informações litológicas e construtivas dos poços, interpretações da geologia estrutural, observação de níveis potenciométricos e obtenção de parâmetros hidráulicos.

O principal aqüífero é o Cristalino, fraturado e, desta forma, caracterizado por uma porosidade de fissuras. Porém, tanto a porção alterada do Cristalino, quanto a cobertura de sedimentos terciários e quaternários, com porosidades intergranulares, são determinantes no comportamento do fluxo da água subterrânea.

O aqüífero sedimentar, com suas camadas de areias intercaladas com argilas, gera aqüíferos suspensos que retardam a recarga para os horizontes mais profundos do aqüífero.

"Com relação às características geológicas / topográficas na variação do comportamento dos níveis d'água nos poços, a Bacia de São Paulo apresenta uma série de intercalações de camadas arenosas de diferentes espessuras e descontínuas horizontal e verticalmente, o que caracteriza o aqüífero como de natureza predominantemente semiconfinado, heterogêneo e anisotrópico, favorecendo a ocorrência de aqüíferos locais com variados graus de conexão 
hidráulica entre si, onde a água subterrânea se encontra sob diferentes cargas hidráulicas" (Bertolo, 1996).

A porção alterada do Cristalino, além de sua porosidade granular, preserva, em maior ou menor grau, a estrutura da rocha, portanto, possui também uma porosidade fissural que a torna bastante permeável.

Observando-se que os poços mais profundos têm pouco mais de $300 \mathrm{~m}$ de profundidade, presume-se que abaixo disso, as potencialidades do aqüífero diminuem e, para efeitos de interpretações conceituais, foi assumido que a cerca de $400 \mathrm{~m}$ de profundidade, o aqüífero Cristalino perde permeabilidade.

"Mesmo com a urbanização, impermeabilizando praticamente a área do afloramento da Bacia Sedimentar de São Paulo, há uma recarga garantida proveniente dos domínios aqüíferos das rochas cristalinas alteradas [...] Acrescentem-se as recargas provenientes das perdas da rede de distribuição de águas" (Rocha, 1989).

De modo geral, a maior parte da área exibe condições de recarga do aqüífero superficial, por infiltração de águas pluviais e perdas da rede pública e, estima-se, conceitualmente, que a descarga dos fluxos de água segue em direção às drenagens principais: rio Pinheiros e canal do Jurubatuba. Não foram obtidos dados suficientes para a elaboração de um mapa potenciométrico representativo do nível freático. As áreas com maior tendência de rebaixamento de carga hidráulica são aproximadamente coincidentes com as áreas com maior exploração.

O fluxo principal da área dirige-se às principais drenagens superficiais, mas é sabido que há fluxos em direção contrária em pontos locais, devido à grande heterogeneidade das condutividades hidráulicas, dentro da sucessão de pacotes argilosos, siltosos e arenosos e recargas antrópicas (Lima et al 2004).

Giancursi e Lopes, 1980, descrevem que a exploração de água subterrânea na bacia de São Paulo se processa de forma bastante irregular, apresentando altas taxas de bombeamento em certas zonas de concentração industrial e empresarial, ao contrário de outras zonas, mais residenciais, onde a exploração é mínima. Esta exploração contínua e concentrada, aliada a problemas de recarga e das características litofaciológicas da bacia, permite a determinação de zonas de rebaixamento contínuo e acentuado do lençol freático, com a conseqüente diminuição da espessura saturada dos sedimentos. Demonstram como exemplos as áreas do eixo BelémTatuapé e do eixo Santo Amaro - Brooklin (área de estudos), onde foram observados rebaixamentos da ordem de 20 metros entre dois períodos de monitoramento considerados (1968 - 70 e 1974 - 75). 
Foram elaborados mapas de carga hidráulica do aqüífero Cristalino em dois intervalos de tempo, considerando dados antes e após o ano de 1990. Devido ao aumento de poços construídos na década de 90 e 2000, é possível perceber que, às margens do canal Jurubatuba, local de maior exploração, os níveis de carga hidráulica foram rebaixados. Embora não se tenha medições nos mesmos poços em diferentes épocas para precisar este rebaixamento, pela configuração das isopotenciais, na Figura 23, estima-se que 0 rebaixamento atingiu cerca de $50 \mathrm{~m}$ de espessura.

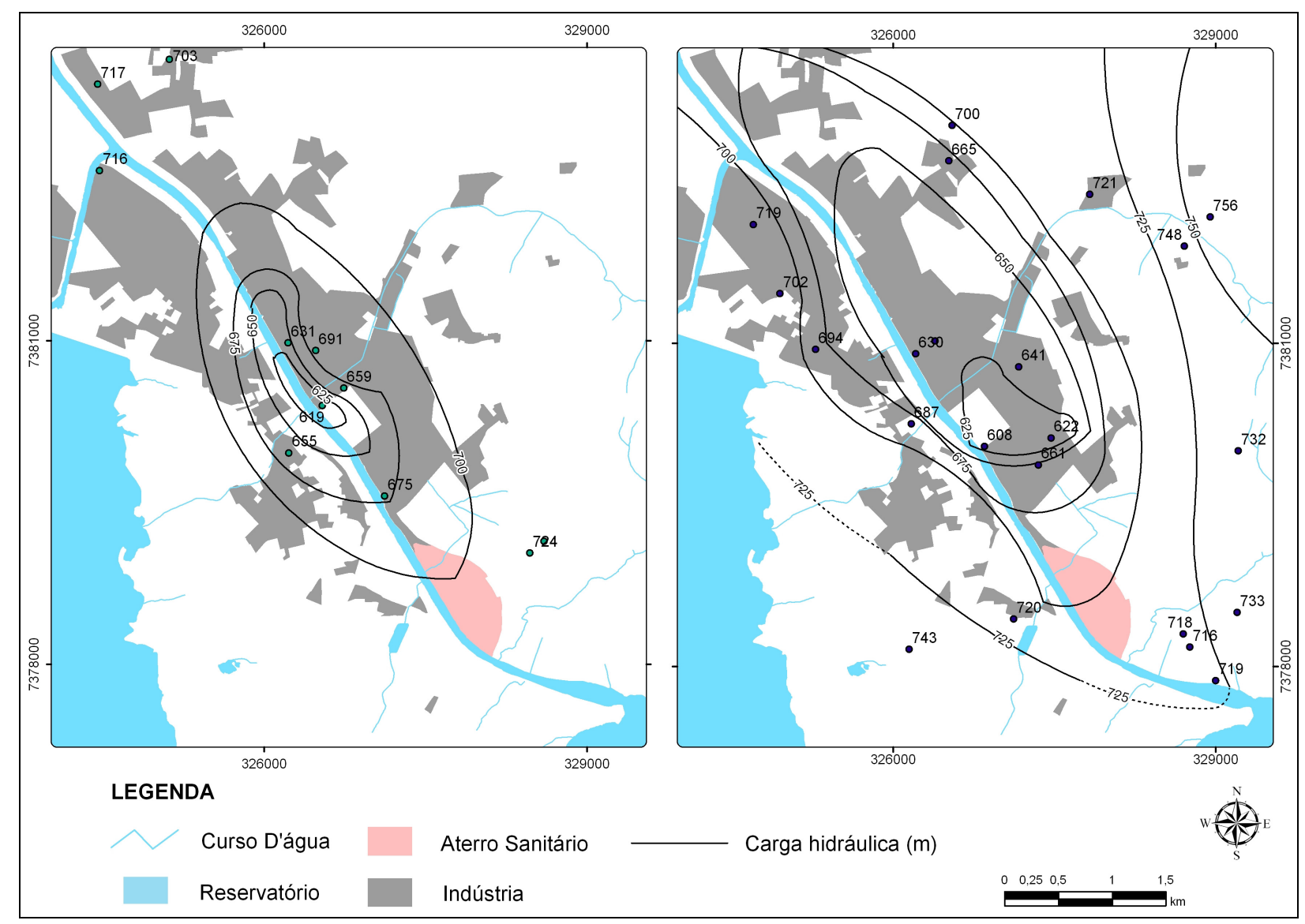

Figura 23 - Rebaixamento do aqüífero cristalino às margens do canal Jurubatuba considerando dados até o ano de 1990 e após 1990.

"A Evolução da exploração do aqüífero ao longo do tempo é um importante fator que interfere no nível d'água nos poços. Quanto mais próximos os poços e quanto maior o numero de poços em operação no momento da leitura do nível d'água num poço, mais profundo será este nível devido às interferências relacionadas aos cones de rebaixamento. Assim, numa área de exploração intensiva de água subterrânea, há uma tendência de que quanto mais novo o poço, mais profundo será o nível d’água no seu interior” (Bertolo, 1996).

Os ensaios com obturadores no aqüífero Cristalino permitiram observar fluxos descendentes às margens dos canais do Jurubatuba e do Guarapiranga e fluxos ascendentes 
às margens do rio Pinheiros. Estas observações, de certo modo, refletem também 0 comportamento da potenciometria, observado na Figura 23.

Nos trabalhos de campo foram observados dois poços de monitoramento instalados na superfície do aqüífero freático (com $7 \mathrm{~m}$ de profundidade), posicionados em lados opostos e a 2 m de um poço de produção (o Poço 1502, cuja localização pode ser observada na Figura 8, no item 5). O poço de produção apresentou o nível d'água a $67 \mathrm{~m}$ de profundidade, enquanto os poços de monitoramento apresentaram níveis d'água a $5 \mathrm{~m}$ de profundidade. Além disso, o poço 1502 situa-se a 30 metros do canal do Jurubatuba. O poço 1502 está exclusivamente no Cristalino, sendo revestido até os $34 \mathrm{~m}$, em sua porção de sedimentos e rocha alterada, e encontra-se desativado por situar-se na área de restrição provisória. Outros dois poços de produção, localizados na mesma propriedade e com perfis litológico-construtivos semelhantes, também apresentaram níveis de água entre 60 e $70 \mathrm{~m}$ de profundidade. Isto demonstra a existência de uma forte componente de potenciais de fluxos verticais descendentes do aqüífero freático (e do canal Jurubatuba) em relação ao aqüífero cristalino profundo.

Outra atividade de campo foi medir o nível de água de 20 poços de produção, em poços paralisados na área de restrição temporária, selecionados mediante a possibilidade de acesso ao poço, existência de tubo guia ou poço sem equipamento, em geral situados na área de restrição provisória. Os níveis d'água medidos foram comparados com os níveis medidos durante a perfuração do poço, anotados no cadastro de poços. A linha média, destacada em preto na Figura 24 mostra que, em geral, os níveis de água se recuperaram, entretanto, há níveis que permaneceram profundos e podem estar associados a bombeamentos de poços clandestinos nas imediações.

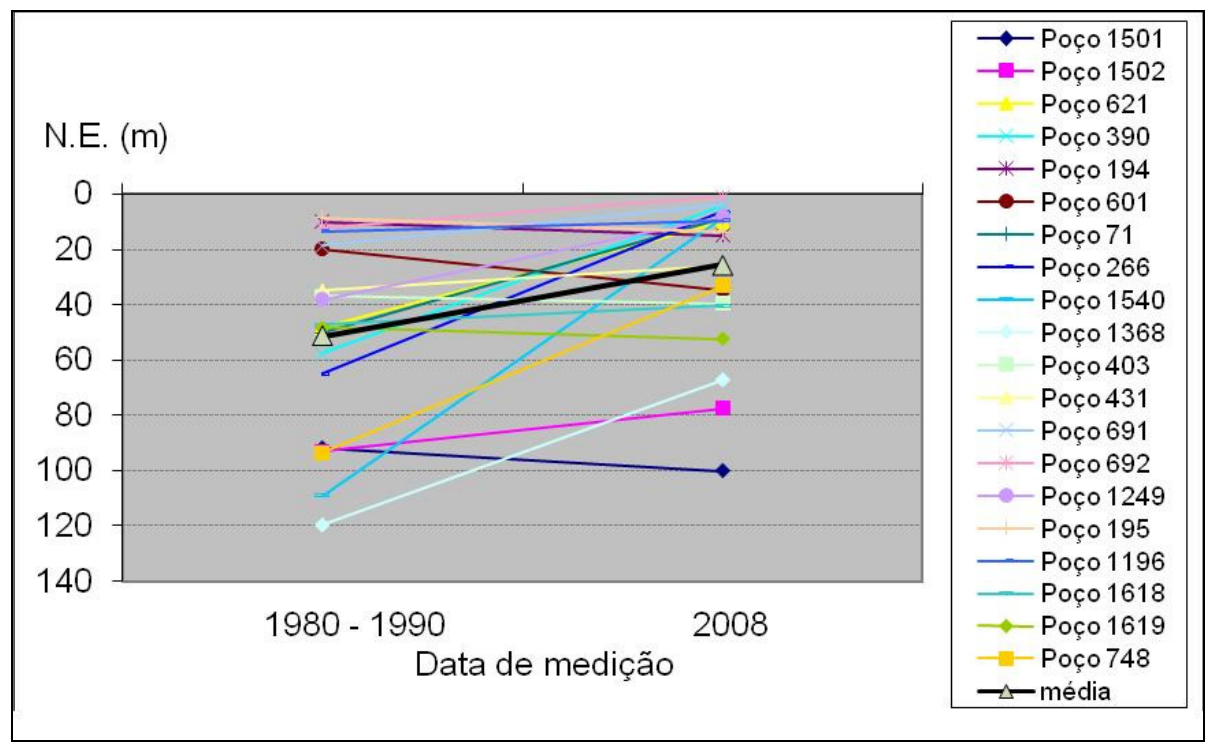

Figura 24 - Nível estático, antigo e atual, da água subterrânea em poços paralisados na área de restrição temporária 
O modelo de fluxo de água subterrânea mostra que no aqüífero sedimentar deve predominar um sistema de fluxo local e o fluxo de água no aqüífero Cristalino, dado por fraturas, está associado a um fluxo local vertical e a um sistema de fluxos horizontais regional.

Neste modelo, observa-se que o fluxo de água subterrânea no aqüífero Sedimentar possui uma relação direta com as fontes primárias e secundárias de contaminação. Já o fluxo de água no aqüífero Cristalino tem a potencialidade de propagar a contaminação a distâncias mais longas do que o aqüífero sedimentar, considerando a dinâmica de fluxos por caminhos preferências que o aqüífero fraturado tem por característica e, também o fato de que o aqüífero cristalino opera sob regimes de bombeamento mais intensos.

A Figura 25 apresenta os dois níveis de água para a região de estudo, sobretudo para a parte central da área, próximo ao canal Jurubatuba. O primeiro nível, mais raso, associado ao aqüífero Sedimentar e concordante com os níveis das drenagens locais e, o segundo nível, mais profundo, resultado do intenso bombeamento do aqüífero cristalino (nível dinâmico), aparentemente deslocado, ou com grande atraso de resposta do aqüífero Sedimentar. É um efeito transiente causado pela forte anisotropia (vertical versus horizontal) dos aqüíferos Cristalino e Sedimentar. Em contraponto a este modelo de forte anisotropia, a rede de poços de produção conecta as partes superiores às inferiores dos aqüíferos.

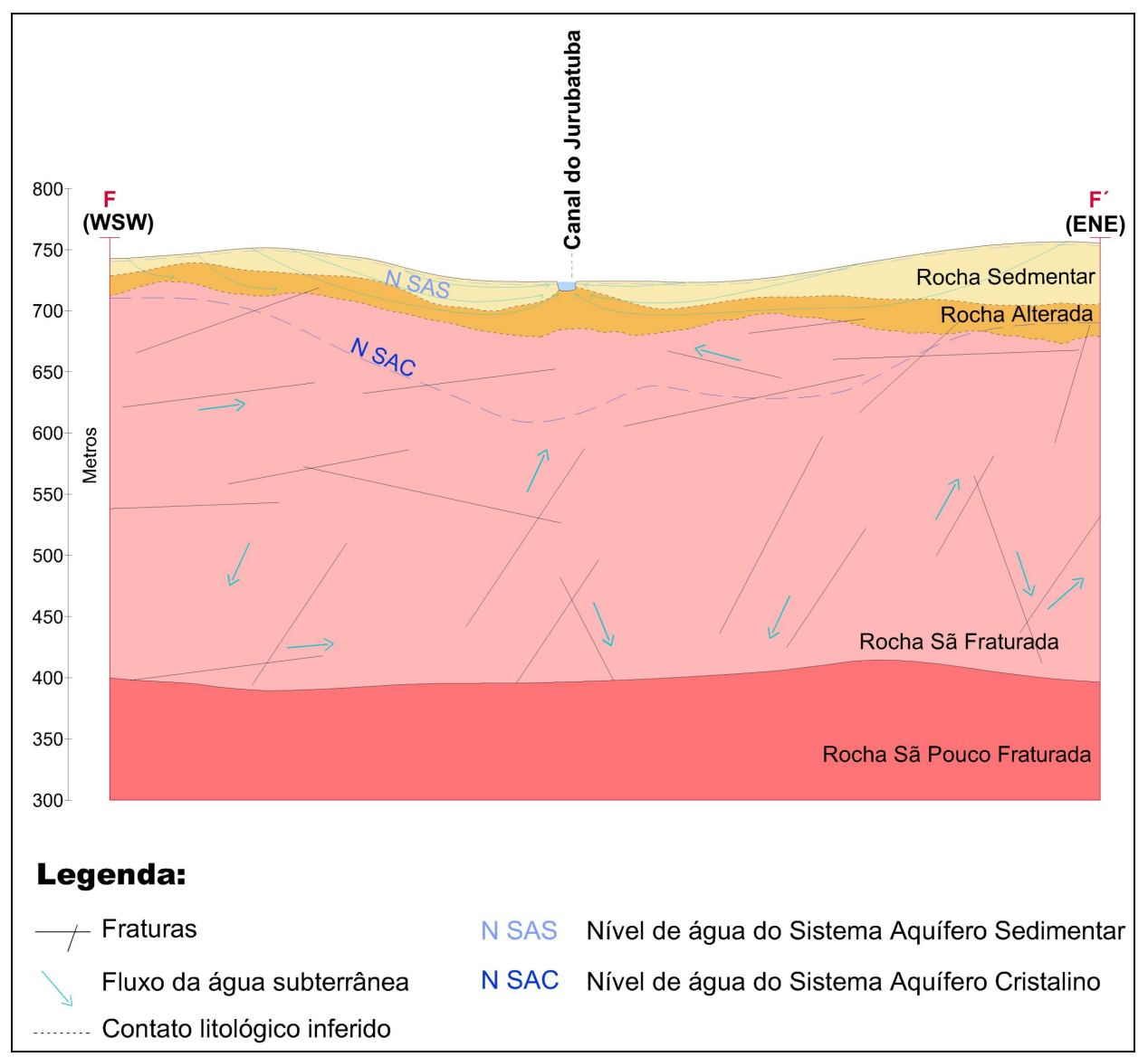

Figura 25 - Modelo Conceitual hidrogeológico. 


\section{RISCO DE CONTAMINAÇÃO DOS AQÜÍFEROS}

O risco de contaminação do aqüífero é uma interação da vulnerabilidade natural do aqüífero com a carga contaminante potencial que pode atingi-lo.

\subsection{Vulnerabilidade Natural dos Aqüíferos}

A vulnerabilidade de um aqüífero à contaminação refere-se à acessibilidade de contaminantes relacionada com as características intrínsecas dos estratos que separam o aqüífero saturado da superfície do solo e as fontes potenciais de cargas contaminantes (Foster et al, 2007).

O índice que indica a vulnerabilidade natural das águas subterrâneas na região do Jurubatuba, segundo as suas características hidrogeológicas, foi determinado utilizando o método GOD (Foster, S. e Hirata, R., 1988). O método GOD significa, originalmente, Groundwater hydraulic confinement, Overlaying Strata, Depth to groundwater table; traduzido como, Grau de confinamento hidráulico, Ocorrências de substrato litológico e Distância do nível d'água ou teto de aqüífero confinado.

Os níveis freáticos foram definidos considerando informações de poços de monitoramento rasos e cacimbas e a topografia. Comparando-se os dados de campo com as cotas topográficas, notou-se que as cotas topográficas mais elevadas apresentam os níveis freáticos mais profundos e, as cotas mais baixas, níveis rasos. Pode-se traçar uma configuração, na qual, na porção central e leste da área, predominam os níveis rasos, menores do que $5 \mathrm{~m}$ e na porção oeste, níveis mais profundos, entre 5 e $20 \mathrm{~m}$.

A vulnerabilidade dos aqüíferos locais foi definida como segue abaixo:

O aqüífero Quaternário apresenta índice de vulnerabilidade alto por conter porções arenoargilosas e devido à baixa profundidade do nível freático, entre 1 e $5 \mathrm{~m}$.

O aqüífero São Paulo apresenta um índice de vulnerabilidade médio devido às porções de silte-argila e ao nível freático ser mais profundo, entre 5 e $20 \mathrm{~m}$.

O aqüífero Resende é dividido em duas fácies. Os depósitos que predominam lamitos areno-argilosos e níveis freáticos rasos, entre 1 e $5 \mathrm{~m}$, possuem um índice de vulnerabilidade alto e, a mesma fácies, com predominância de nível freático mais profundo, maior do que $5 \mathrm{~m}$, apresenta índice médio, assim, como a camada que há predominância de lamitos acamados e níveis freáticos maiores do que $5 \mathrm{~m}$, o um índice de vulnerabilidade é médio. 
O aqüífero Cristalino apresenta grande heterogeneidade hidráulica e baixa densidade de dados, dificultando a determinação da vulnerabilidade do aqüífero. Na região, o estrato de cobertura caracterizado pelo intemperismo de rochas metamórficas e ígneas e níveis freáticos médios, entre 5 e $20 \mathrm{~m}$, a profundos, maiores do que de $20 \mathrm{~m}$, permitiu classificar o aqüífero Cristalino como tendo um índice de vulnerabilidade médio.

A Figura 26 apresenta os resultados finais de vulnerabilidade, enquadrada na metodologia POSH. A área de média vulnerabilidade decorreu de resultados observados no aqüífero São Paulo, no aqüífero Cristalino e em parte do aqüífero Resende. A área de alta vulnerabilidade decorreu de resultados do aqüífero do Quaternário e de parte do aqüífero Resende. As áreas de alto grau de vulnerabilidade, em geral, coincidem com as áreas mais industrializadas.

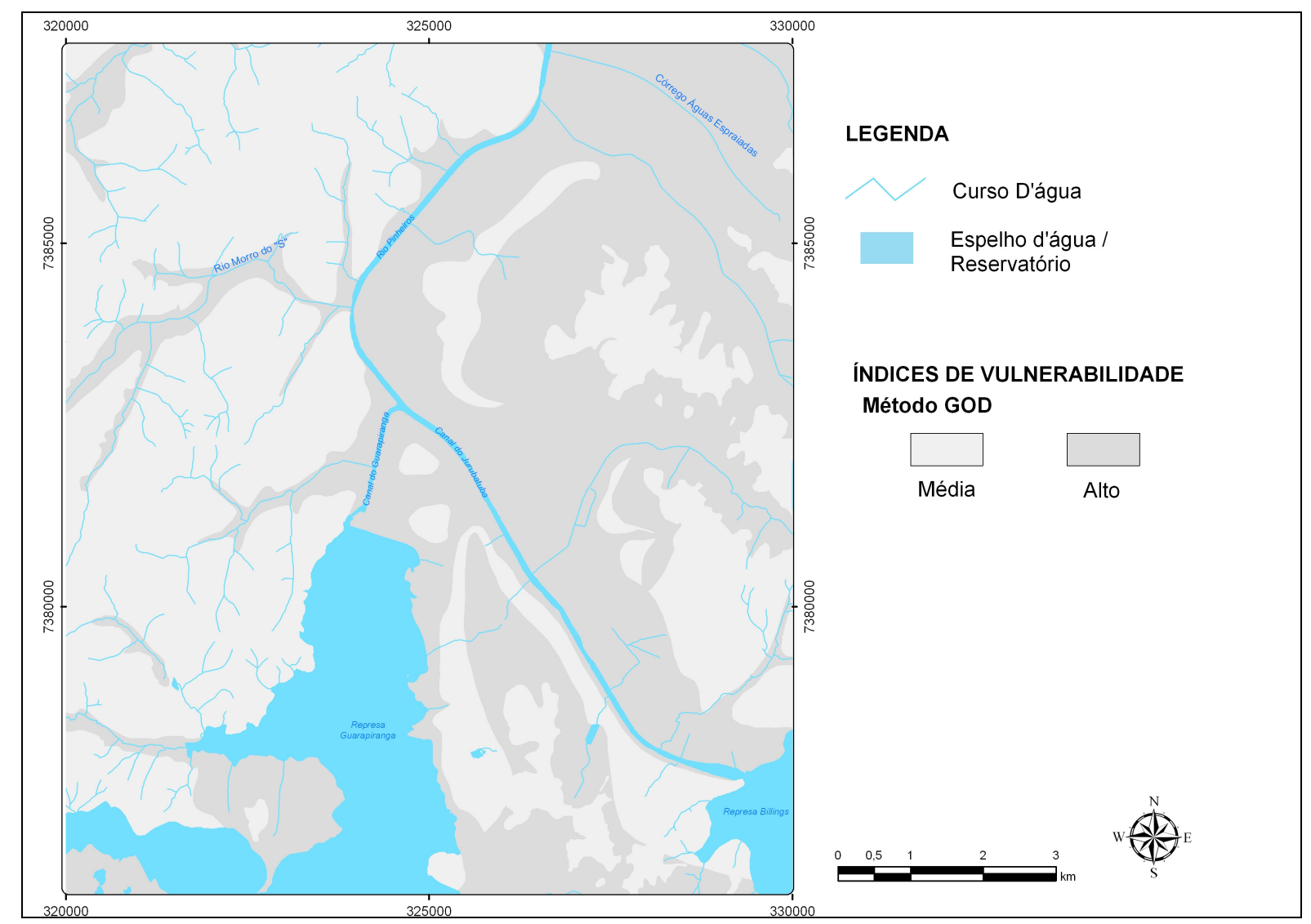

Figura 26 - Vulnerabilidade natural dos aqüíferos à contaminação.

\subsection{Cargas Potenciais de Contaminação}

Uma forma simplificada e efetiva de classificar as fontes potenciais de carga contaminante se dá pelo método Pollutant Origin, Surcharge Hydraulically (POSH) proposto por Foster e Hirata (1988), que aponta as atividades industriais em três níveis qualitativos de 
potencial para gerar uma carga contaminante: Reduzido, Moderado e Elevado. Considera-se o tipo industrial (galvanoplastia, petroquímicos, farmacêuticos) e o grupo contaminante (metais pesados, hidrocarbonetos, solventes orgânicos halogenados).

Em termos gerais, qualquer atividade industrial pode contaminar o solo ou subsolo em decorrência da emissão de efluentes líquidos, do despejo inadequado de resíduos sólidos e de vazamentos de produtos químicos perigosos (Foster et al 2006).

A classificação do potencial de geração de carga contaminante no subsolo, pelo método $\mathrm{POSH}$, considera fontes de contaminação tais como: áreas industriais, lagoas de águas residuais, mineração, exploração de petróleo, deposição de resíduos e outras atividades urbanas. Para a área de estudos foram focadas as áreas industriais, que são subdivididas em indústrias do tipo 1, tipo 2 e tipo 3.

Para as áreas industriais, os graus de potencial de geração de carga contaminante se elevam gradativamente conforme o tipo de atividade industrial. A Tabela 6 apresenta a correlação de atividades industriais e potencial de geração de carga contaminante.

\begin{tabular}{|l|l|l|}
\hline \multicolumn{2}{|c|}{ Tabela 6 - Correlação de atividades industriais e potencial de geração de carga contaminante. } \\
\hline $\begin{array}{c}\text { potencial de geração } \\
\text { de carga contaminante }\end{array}$ & tipo industrial & \multicolumn{1}{|c|}{ atividades de cada tipo industrial } \\
\hline Reduzido & Tipo 1 & $\begin{array}{l}\text { madeireiras, manufaturas de alimento e bebidas, } \\
\text { destilarias de álcool e acúcar, processamento de } \\
\text { materiais não metálicos. }\end{array}$ \\
\hline Moderado & Tipo 2 & $\begin{array}{l}\text { fábricas de borracha, fábricas de papel e celulose, } \\
\text { industrias têxteis, fábricas de fertilizantes, usinas } \\
\text { elétricas, fábricas de detergentes e sabão. }\end{array}$ \\
\hline Elevado & Tipo 3 & $\begin{array}{l}\text { oficinas de engenharia; refinarias de gás e petróleo; } \\
\text { fábricas de produtos químicos, farmacêuticos, } \\
\text { plásticos, pesticidas; curtumes, industrias eletrônicas } \\
\text { e processamento de metal. }\end{array}$ \\
\hline
\end{tabular}

Utilizando-se o Sistema de Fontes de Poluição - SIPOL da CETESB foram levantadas, na área de estudos, 3.905 atividades econômicas e classificadas 2.490 áreas com potencial elevado de contaminação. Este número é bastante expressivo ao se considerar que a área tem uma ocupação mista, com a alta densidade populacional, além de uma rede de poços de produção, muitos desses desconhecidos, disseminados "aleatoriamente" entre estas áreas com potencial elevado de contaminação.

A Figura 27 exibe a distribuição das 3.905 atividades com potencial de contaminação, diferenciadas nos índices elevado, moderado e reduzido. É possível observar que o método apresentou boa coerência ao verificar que os principais adensamentos das 2.490 Áreas com 
Potencial Elevado de Contaminação (AEPC) se concentraram justamente nos perímetros industriais obtidos no mapa de uso e ocupação do solo. Pôde-se observar, entretanto, um adensamento de AEPC no extremo leste da área, que não aparece como ocupação industrial no mapa de uso e ocupação.

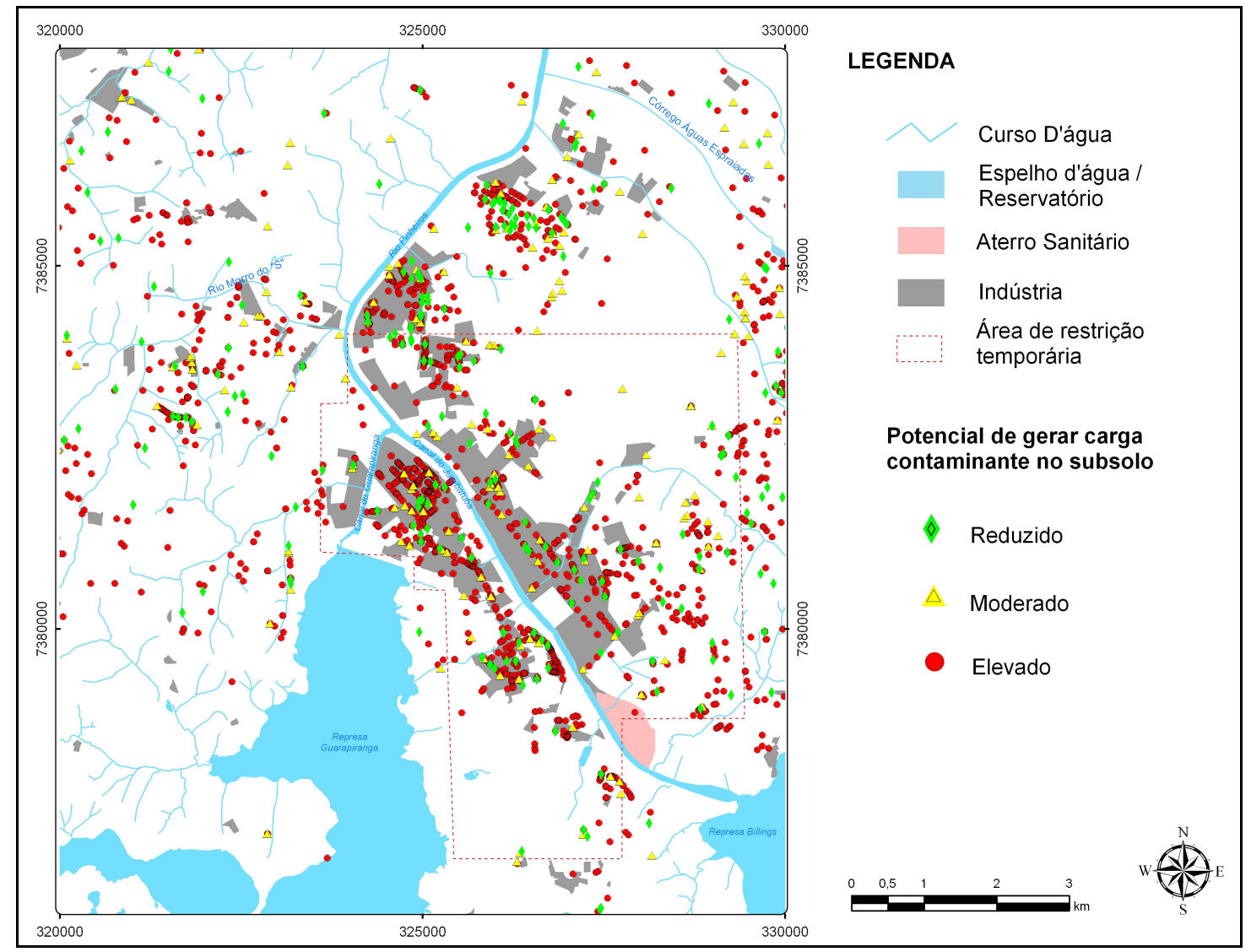

Figura 27 - Índices de atividades com carga potencial de contaminação.

As 2.490 Áreas com Potencial Elevado de Contaminação (AEPC) foram classificadas conforme as características químicas e índices de risco, relativos ao manuseio de substâncias tóxicas ou nocivas, como hidrocarbonetos, solventes orgânicos sintéticos, metais pesados etc. Segundo Foster et al (2007) em todos esses casos, o índice de potencial de contaminação do subsolo deve ser elevado. Os principais tipos de atividades industriais na área são de manufatura de produtos químicos orgânicos, elétricos eletrônicos, farmacêuticos e produtos plásticos.

O manuseio inadequado de produtos químicos, tóxicos ou nocivos, pode provocar extensas contaminações de difícil remediação, por isso são classificados como potencial elevado de contaminação.

A interação da vulnerabilidade com as cargas potenciais contaminantes mostram um resultado negativo, visto que justamente as zonas de vulnerabilidade alta coincidem com 0 
maior adensamento de cargas contaminantes. O Mapa 2, foi produzido com o cruzamento das informações sobre as atividades com carga potencial de contaminação e os índices de vulnerabilidade dos aqüíferos. É notável que os riscos mais extremos ocorrem principalmente às margens dos canais Jurubatuba e Guarapiranga e, à margem direita do rio Pinheiros, onde o maior adensamento de AEPC ocorre sobre as zonas de vulnerabilidade natural alta.

A região norte da área de estudos, à margem esquerda do rio Pinheiros, bem como o extremo sudoeste da área, a oeste da represa Guarapiranga são as localidades de menor risco em vista da quase ausência de áreas com carga potencial e da predominância de zonas de vulnerabilidade natural média. 


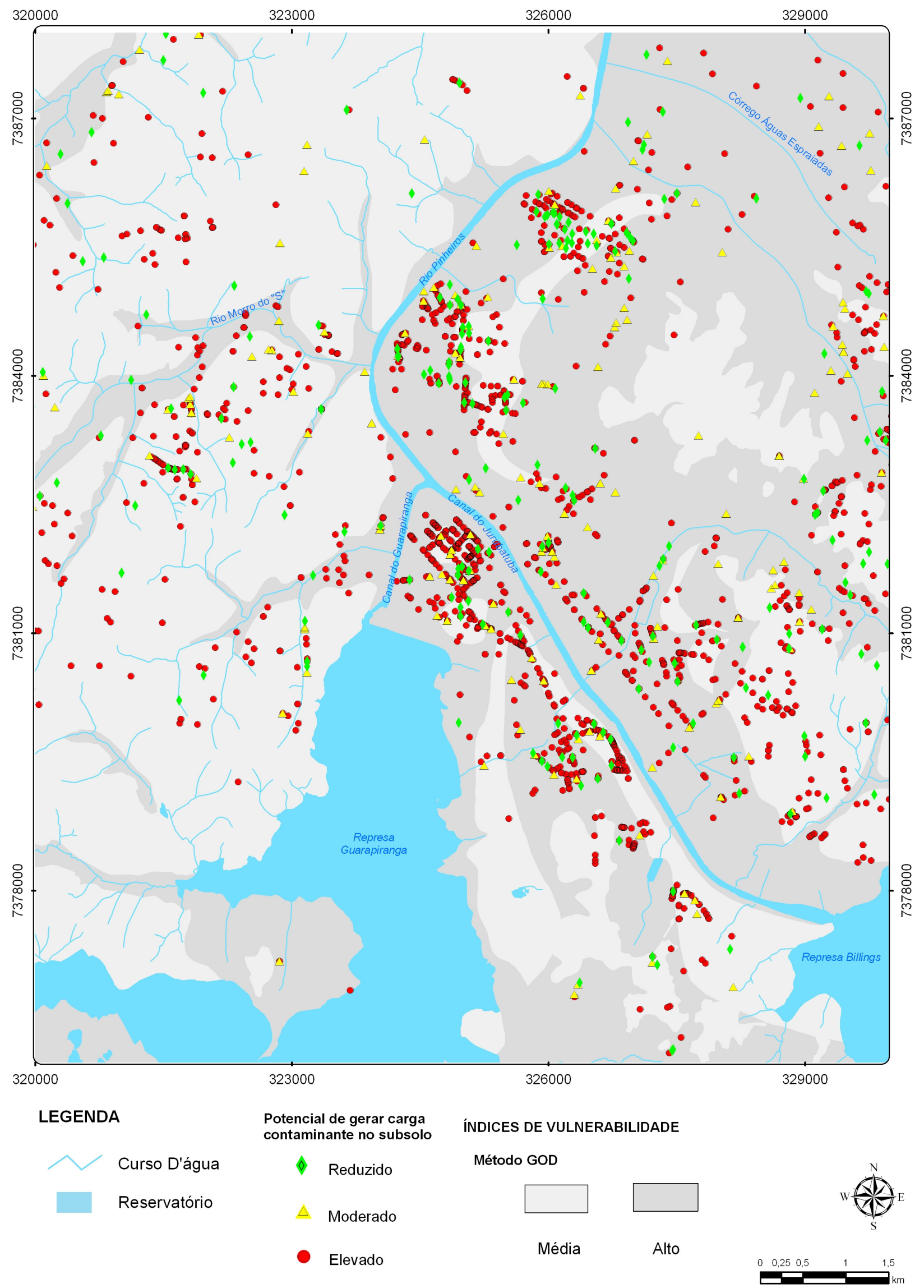

Mapa 2 - Cruzamento de informações sobre as atividades com carga potencial de contaminação e os índices de vulnerabilidade natural dos aqüíferos. 


\section{CARACTERIZAÇÃO DA CONTAMINAÇÃO}

\subsection{Compostos de Interesse}

Os compostos de interesse neste trabalho são os etenos clorados (EEC) e os etanos clorados (EAC). São hidrocarbonetos clorados alifáticos, caracterizados como compostos orgânicos voláteis e pertencem ao grupo químico dos solventes halogenados alifáticos.

Os EEC considerados no trabalho são o percloroetileno (PCE), o tricloroeteno (TCE), os dicloroetenos (cis-1,2-DCE; 1,1-DCE e trans-1,2-DCE) e o cloreto de vinila (CV). Os EAC considerados foram o tricloroetano (TCA) e os dicloroetanos (1,2-DCA e 1,1-DCA). A seleção destes compostos foi definida devido à freqüência de ocorrência observada nos resultados das análises dos poços distribuídos na área.

Uma característica marcante dos compostos de interesse é o fato de se degradarem numa cadeia seqüencial. O processo mais comum de degradação dos EEC é a decloração redutiva, que ocorre pela seguinte seqüência: PCE, TCE, DCE, CV e eteno, onde o átomo de cloro é removido e dá lugar a um átomo de hidrogênio (Figura 28).

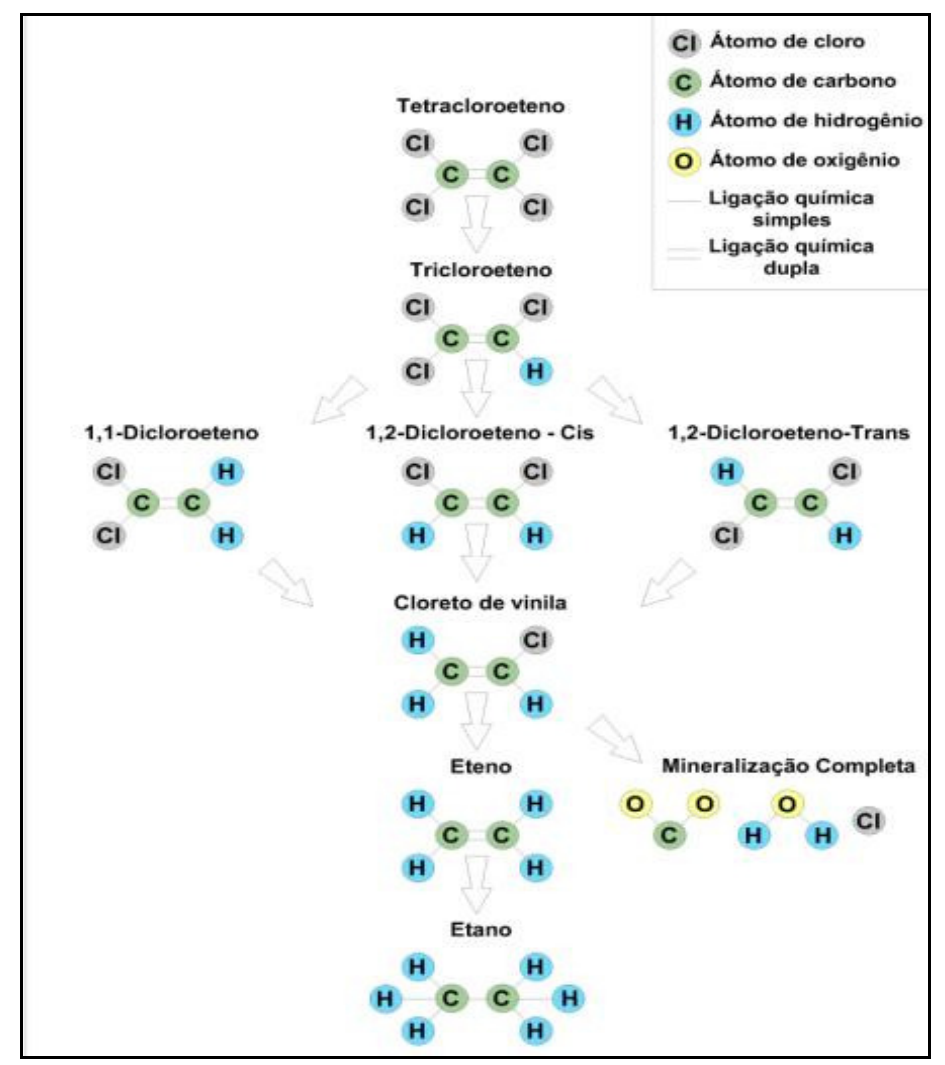

Fonte: USEPA (1998)

Figura 28 - Cadeia de degradação de etenos clorados por decloração redutiva. 
Embora o principal processo de biodegradação destes compostos seja a decloração ou desalogenação redutiva, os hidrocarbonetos clorados alifáticos se submetem à biodegradação em três diferentes circunstâncias: por processos de recepção de elétrons, doação de elétrons, cometabolismo e pela conjugação de dois ou mais desses processos. Após o consumo de oxigênio do meio, os microorganismos anaeróbicos utilizam o $\mathrm{NO}_{3}^{-}, \mathrm{FeOOH}^{-}, \mathrm{SO}_{4}{ }^{2-}$ e, finalmente, $\mathrm{CO}_{2}{ }^{-}$, nesta ordem, preferencialmente (USEPA, 1998).

Com relação à degradação de $E A C$, em geral, esse processo ocorre na seqüência de perda de cloro do TCA para o 1,1-DCA e, deste, para o etano. A emissão deste produto para o ambiente decorre da fabricação, uso, armazenamento, distribuição ou disposição final.

O comportamento de degradação dos compostos de interesse torna o gerenciamento da área estudada mais complexo porque não se pode considerar simplesmente que um poço pode ser utilizado por não conter um composto EEC acima dos VOI, uma vez que o processo degradativo propicia maiores variações nas concentrações dos compostos. Por exemplo, um poço pode ter concentrações de DCE e CV pouco abaixo do VOI e, sob uma variação de parâmetros físico-químicos, por degradação do DCE, o CV passa a ter concentrações acima do VOI.

Os solventes halogenados alifáticos, quando em fase livre, são mais densos do que água e, quando atingem o aqüífero, aprofundam até encontrar uma barreira física ou até que sua massa seja dissipada. As características de porosidade de fraturas do aqüífero cristalino favorecem a propagação destes solventes na área fonte. Quando em fase dissolvida, estes contaminantes são transportados pelo movimento advectivo da água subterrânea. A Tabela 7 apresenta algumas das propriedades dos EEC e EAC.

\begin{tabular}{|l|r|r|r|}
\hline \multicolumn{4}{|c|}{ Tabela 7 - Propriedades dos EEC e EAC. } \\
\hline \multicolumn{1}{|c|}{ Parâmetro } & Densidade & Solubilidade & Pressão de vapor \\
\hline & $\left(\mathrm{g} / \mathrm{cm}^{3}\right)$ & $(\mathrm{mg} / \mathrm{L})$ & $(\mathrm{mmHg})$ \\
\hline PCE & 1,625 & 150 & 14 \\
\hline TCE & 1,462 & 1000 & 58,7 \\
\hline 1,1-DCE & 1,214 & 400 & 500 \\
\hline cis 1,2-DCE & 1,248 & 3500 & 200 \\
\hline trans 1,2-DCE & 1,257 & 6300 & 265 \\
\hline CV & $0,908^{*}$ & $8800^{*}$ & $2530^{*}$ \\
\hline 1,1-DCA & 1,175 & 5500 & 182 \\
\hline 1,2-DCA & 1,253 & 8690 & 63,7 \\
\hline 1,1,1-TCA & 1,325 & 950 & 100 \\
\hline & & Fonte: (Huling e Weaver, 1991) \\
& & & * Fonte: (University of Waterloo)
\end{tabular}


OS EEC e EAC são classificados como volatile organic compounds (VOC), compostos orgânicos voláteis, caracterizados por uma alta pressão de vapor, tendo maior tendência de passar de seu estado sólido ou líquido para o estado de vapor e podendo persistir no ar em concentrações elevadas. São compostos tóxicos ao organismo humano, mesmo em baixas concentrações e, por isso, deve-se obter um maior controle ao manuseá-los. Se usados de forma incorreta, podem acarretar efeitos adversos para a saúde, podendo até causar o câncer.

Os compostos de interesse são utilizados na indústria, principalmente, como desengraxantes. A Tabela 8 apresenta algumas informações sobre uso, exposição e efeitos no ser humano.

\begin{tabular}{|c|c|c|c|}
\hline \multicolumn{4}{|c|}{ Tabela 8 - Utilização, tipo de exposição e efeitos no ser humano. } \\
\hline Parâmetro & Uso & $\begin{array}{l}\text { Tipo de } \\
\text { exposição }\end{array}$ & Efeitos no ser humano \\
\hline PCE & $\begin{array}{l}\text { limpeza a seco de tecidos, } \\
\text { desengraxante de metais, matéria- } \\
\text { prima para produção de compostos } \\
\text { químicos artificiais. }\end{array}$ & \multirow{8}{*}{$\begin{array}{l}\text { Inalação } \\
\text { contato dérmico } \\
\text { e ingestão }\end{array}$} & $\begin{array}{l}\text { afeta o sistema nervoso } \\
\text { central }\end{array}$ \\
\hline TCE & removedor de graxas & & $\begin{array}{l}\text { afeta o sistema nervoso } \\
\text { central e provoca danos ao } \\
\text { rim e fígado. }\end{array}$ \\
\hline 1,1-DCE & $\begin{array}{l}\text { intermediário químico na síntese de } \\
\text { organoclorados e produção de } \\
\text { embalagens }\end{array}$ & & $\begin{array}{l}\text { dor de cabeça, fadiga com } \\
\text { alterações nervosas, } \\
\text { irritações nos olhos; em } \\
\text { contato com a pele, leva a } \\
\text { secura; }\end{array}$ \\
\hline 1,2-DCE & $\begin{array}{l}\text { intermediário químico na síntese de } \\
\text { organoclorados, solvente, resinas, } \\
\text { corantes }\end{array}$ & & $\begin{array}{l}\text { quando ingerido causa } \\
\text { danos ao sistema } \\
\text { gastrointestinal }\end{array}$ \\
\hline CV & produção do PVC* e copolímeros & & câncer de fígado \\
\hline 1,1-DCA & $\begin{array}{l}\text { intermediário químico na síntese de } \\
\text { organoclorados, na fabricação de } \\
\text { polimento e aerossol de inseticidas }\end{array}$ & & $\begin{array}{l}\text { depressão do sistema } \\
\text { nervoso central e irritação } \\
\text { do trato respiratório e do } \\
\text { tecido cutâneo }\end{array}$ \\
\hline $1,2-\mathrm{DCA}$ & $\begin{array}{l}\text { síntese de outros compostos químicos } \\
\text { envolvidos na produção de plásticos, } \\
\text { como PVC; borrachas e fibras têxteis } \\
\text { sintéticas. }\end{array}$ & & $\begin{array}{l}\text { causar aparecimento de } \\
\text { cancro }\end{array}$ \\
\hline $1,1,1-\mathrm{TCA}$ & $\begin{array}{l}\text { limpeza de metais, em aerossóis, } \\
\text { adesivos, revestimentos, limpeza a } \\
\text { seco e em processos têxteis e } \\
\text { eletrônicos. }\end{array}$ & & $\begin{array}{l}\text { náuseas, vômito, diarréia, } \\
\text { queimaduras na pele, } \\
\text { depressão respiratória e } \\
\text { arritmia cardíaca }\end{array}$ \\
\hline
\end{tabular}

Fonte: Salgado e Marona, (2004) 
Embora na área de estudo ocorram outros compostos orgânicos e inorgânicos acima do VOI, que podem ser de origem natural ou resultante de atividades antrópicas, estas ocorrências são pontuais e não foram o foco de interesse neste trabalho.

\section{2 Áreas Contaminadas Declaradas}

Áreas Contaminadas Declaradas (ACD) são as submetidas ao processo de Gerenciamento de Áreas Contaminadas da CETESB e a ocorrência de contaminação foi comprovada.

O levantamento de ACD pela CETESB, com a atualização de novembro de 2007, mostrou 84 Áreas Contaminadas Declaradas na área de estudo, sendo 55 postos de combustíveis e 29 indústrias. Dentre as 29 indústrias, apenas 14 foram declaradas contaminadas por EEC ou EAC (Figura 29). Estes números não refletem o cenário regional de contaminação por EEC e EAC. Esta contradição ocorre porque os postos de combustível estão com suas investigações mais adiantadas em relação às indústrias, sendo que, diversas investigações em andamento deverão aumentar a proporção de áreas declaradas contaminadas por EEC e EAC. Em 2008, foram incluídas mais três indústrias, totalizando 17 Áreas Contaminadas Declaradas, contaminadas por EEC ou EAC.

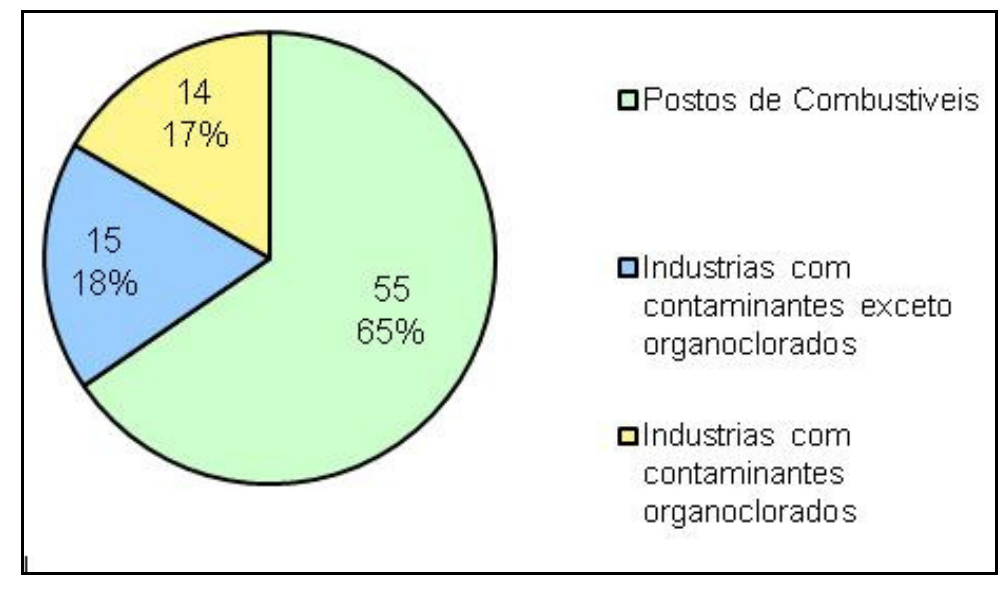

Fonte: CETESB, 2007

Figura 29 - Categorias de áreas contaminadas.

A Figura 30 apresenta a localização das 17 áreas declaradas contaminadas por EEC ou EAC na área de estudo, com atualização de 2008. 


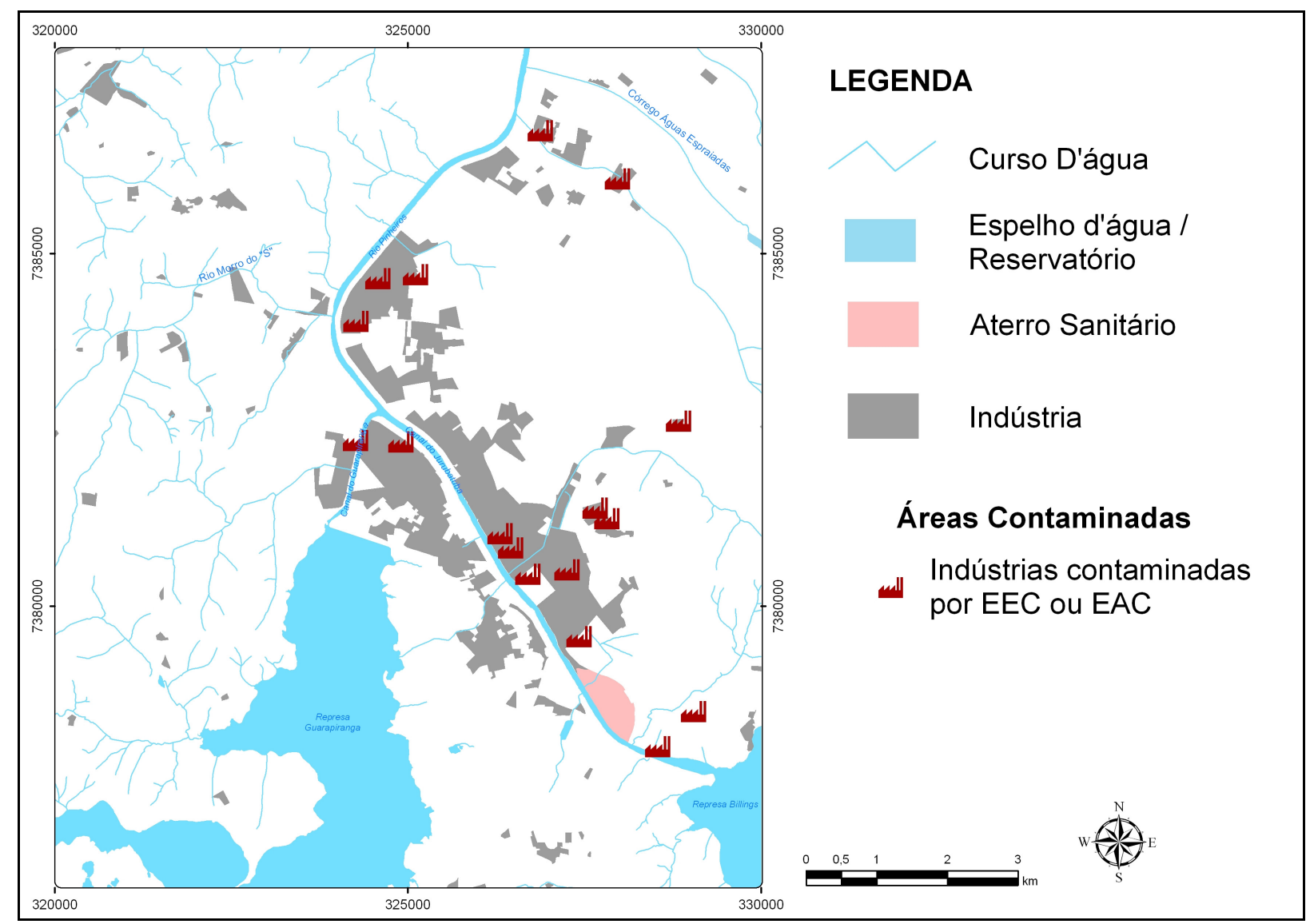

Figura 30 - Áreas declaradas contaminadas por EEC ou EAC.

Ao se considerar apenas as contaminações por organoclorados, as principais fontes de contaminação nas indústrias da área de estudo são (Figura 31) a área de produção (40\%) e a área de armazenagem (20\%).

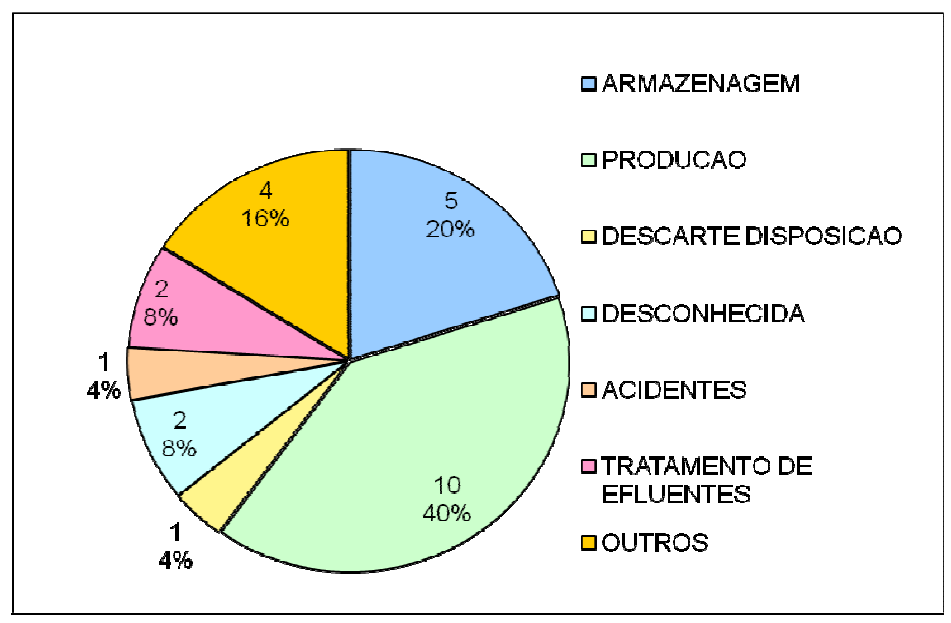

Fonte: CETESB, 2008

Figura 31 - Fontes de contaminação por solventes halogenados alifáticos em áreas industriais. 
Conforme o Manual de Gerenciamento de Áreas Contaminadas da CETESB, deve-se cumprir uma seqüência de etapas de gerenciamento. Entre as 17 áreas contaminadas por EEC ou EAC, as principais fases dos trabalhos realizadas foram investigações confirmatórias e detalhadas (Figura 32). Não há informações sobre avaliações preliminares. Seis áreas, entre as 17 , estão com remediação em andamento.

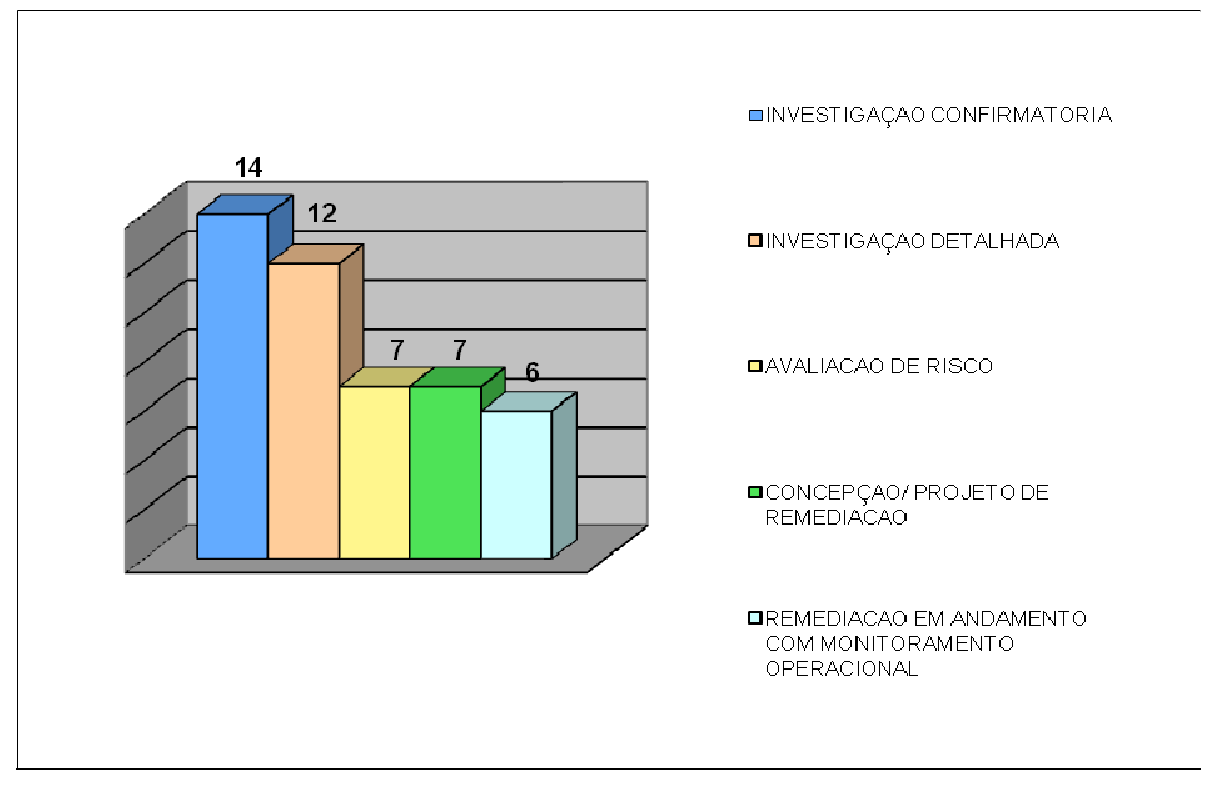

Fonte: CETESB, 2007

Figura 32 - Etapas de trabalhos realizadas nas áreas contaminadas por EEC ou EAC.

Em vistas a processos de algumas das principais áreas declaradas contaminadas no cadastro da CETESB, verificou-se concentrações médias da ordem de dezenas e até de centenas de miligramas por litro nos poços de monitoramento no aqüífero raso, junto às áreas fontes de contaminação. A concentração mais alta de um composto foi de cis-1,2-DCE, acima de $200 \mathrm{mg} / \mathrm{L}$. Considerando que a solubilidade do cis-1,2-DCE é cerca de $3.500 \mathrm{mg} / \mathrm{l}$ e há outros compostos na solução, o valor acima de $200 \mathrm{mg} / \mathrm{L}$ é indicativo de ocorrência de fase livre de solvente em torno do ponto amostrado.

A experiência tem demonstrado que um DNAPL pode estar presente em fase livre quando um composto é detectado em concentrações acima de $1 \%$ de sua solubilidade efetiva (Kueper et al, 2003).

A Tabela 9 apresenta os valores máximos e médios, das concentrações em micrograma por litro, de EEC e EAC em poços de monitoramento para cada composto nas quatro áreas observadas, considerando-se os laudos que foram acessados. 


\begin{tabular}{|c|c|c|c|c|c|c|c|c|c|c|c|}
\hline \multirow{2}{*}{$\begin{array}{l}\text { Parâmetros } \\
\text { unidade } \\
(\mu \mathrm{g} / \mathrm{L})\end{array}$} & \multicolumn{2}{|c|}{$\begin{array}{l}\text { Empresa } 1 \\
26 \text { PM }\end{array}$} & \multicolumn{2}{|c|}{$\begin{array}{l}\text { Empresa } 2 \\
66 \text { PM profundos } \\
\end{array}$} & \multicolumn{2}{|c|}{\begin{tabular}{|l} 
Empresa 2 \\
33 PM rasos \\
\end{tabular}} & \multicolumn{2}{|c|}{\begin{tabular}{|r|} 
Empresa 3 \\
$30 \mathrm{PM}$ \\
\end{tabular}} & \multicolumn{2}{|c|}{\begin{tabular}{|r|} 
Empresa 4 \\
104 PM \\
\end{tabular}} & \multirow{2}{*}{ VOI } \\
\hline & Máx. & Média & Máx. & Média & Máx. & Média & Máx. & Média & Máx. & Média & \\
\hline PCE & 49.000 & 19.288 & - & - & - & - & 286 & 14 & 134 & 2 & 40 \\
\hline TCE & 7.363 & 522 & 17.101 & 903 & - & - & 873 & 56 & 102.000 & 1.039 & 70 \\
\hline cis-1,2-DCE & 4.913 & 50 & 4.924 & 431 & 1.030 & 72 & 138.000 & 8.608 & 211.000 & 6.913 & (a) \\
\hline 1,1-DCE & - & - & 754 & 45 & \begin{tabular}{|r|}
- \\
\end{tabular} & - & \begin{tabular}{|l}
3.450 \\
\end{tabular} & 149 & 395 & 13 & 30 \\
\hline trans-1,2-DCE & - & - & & - & - & - & 1.050 & 68 & 841 & 49 & (a) \\
\hline C V & 938 & 127 & 7.068 & 418 & 1.144 & 55 & 65.000 & 4.307 & 42.600 & 2.147 & 5 \\
\hline 1,1-DCA & & & 646 & 18 & - & - & 3.600 & 248 & 26 & 1 & 280 \\
\hline
\end{tabular}

49000 - concentração acima dos Valores Orientador de Intervenção (VOI) para a água subterrânea (CETESB, 2005)

18 - concentração abaixo do VOI

(-) não detectado

(a) somatória para cis-1,2-DCE e trans-1,2-DCE = $50 \mu \mathrm{g} / \mathrm{L}$.

Para a tomada de decisões no gerenciamento do problema, uma verificação relevante nos relatórios acessados é que, numa projeção horizontal, observando-se as plumas de contaminação, nota-se que as contaminações analisadas extrapolam os limites da propriedade do contaminador, tornando, consequentemente, áreas vizinhas também contaminadas. Isto tem uma importância fundamental para a tomada de decisões, uma vez que esta situação aponta para a necessidade de uma ação conjunta entre as diversas plantas contaminadoras e as plantas receptoras da contaminação. A melhor maneira de trabalhar numa solução é investigar localmente e, gerenciar regionalmente, sob uma mediação do órgão gestor. A associação das indústrias pode intermediar, num contexto regional, as negociações para uma ação conjunta entre as diversas plantas contaminadoras e as plantas receptoras da contaminação.

Outra abordagem sobre as áreas contaminadas vistas na CETESB está relacionada às fontes secundárias de contaminação, decorrentes do descarte de efluente em galerias de drenagem das indústrias, em área sem coleta de esgoto.

Ao observar a rede de coleta de esgotos, nota-se que a área industrial no bairro de Campo Grande, onde ocorreram as primeiras evidências do cenário regional de contaminação, é coincidente com a área não servida por esta rede. As galerias de drenagem de efluentes, nas propriedades, são conectadas às galerias pluviais da rede pública que, em geral, tem como destino córregos e canais, a exemplo do canal do Jurubatuba. Neste caminho, a existência de trincas nas galerias pode criar múltiplos pontos de infiltração de contaminantes para o aqüífero. Para o caso de encaminhamento destes efluentes para fossas, pode-se considerar ocorrências similares a estas no processo de contaminação. 
Numa das áreas declaradas contaminadas, no bairro Campo Grande a leste do canal Jurubatuba, observou-se sedimentos em galerias, com concentração de PCE de de 56.000 $\mathrm{mg} / \mathrm{kg}$, ou seja, acima de $50 \mathrm{~g} / \mathrm{kg}$. Isto mostra a presença de fontes ativas de contaminação.

A Figura 33 apresenta um modelo, a partir de uma ocorrência real de galeria contaminada, conectada à rede de galerias pluviais. O trecho de rede pluvial (em verde) é conhecido e o trecho de rede pluvial (em laranja) é inferido. A figura ilustra um modelo de disseminação da contaminação que deve ser investigado.

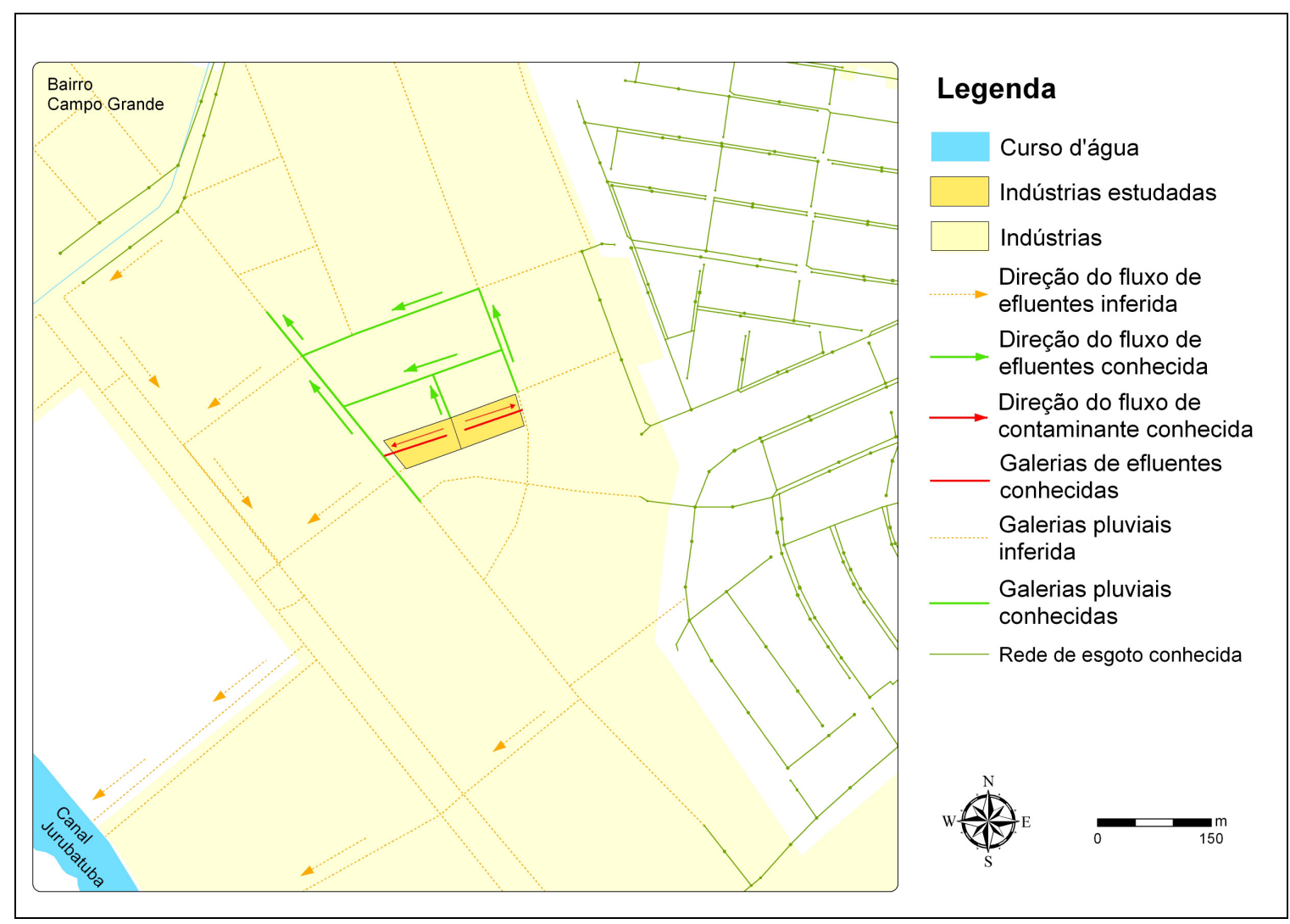

Figura 33 - Modelo de galeria com contaminante conectada à rede de galerias pluviais.

Também foram observadas, na mesma galeria, concentrações da ordem de $\mathrm{g} / \mathrm{kg}$ de tricloroetano (TCA); 1,1-dicloroeteno (DCE) e 1,1-dicloroetano (DCA). Outros compostos em menores concentrações foram o TCE, cis-1,2-DCE e CV (produtos de degradação do PCE), além de compostos comuns na gasolina (BTXE) e o mercúrio. Considerando as propriedades de densidade dos EEC originais (PCE e TCE) quando em fase não-aquosa (Dense Nonaqueous Phase Liquids - DNAPL), o PCE e o TCE, por serem mais densos do que a água, atingem o aqüífero e aprofundam até encontrar uma barreira física, ou até que sua massa seja dissipada. 
Contrastando a ocorrência de $50 \mathrm{~g}$ de PCE em $1 \mathrm{~kg}$ de solo e o VOI do PCE $(40 \mu \mathrm{g} / \mathrm{L})$ para a água subterrânea, nota-se que estes $50 \mathrm{~g}$ são suficientes para contaminar, inicialmente 1.250.000 L de água. Inicialmente, porque, com a degradação até o CV, este volume seria ainda maior. Como a água de um aqüífero está nos seus poros, que equivalem a menos de $50 \%$ do volume total do aqüífero, $2.500 \mathrm{~m}^{3}$ do aqüífero estariam comprometidos. Ou seja, $50 \mathrm{~g}$ de PCE podem contaminar, no mínimo, uma camada do aqüífero de $25 \mathrm{~cm}$ de espessura em todo um quarteirão.

Embora as fichas de áreas contaminadas da CETESB apontem que as principais fontes de contaminação por EEC e EAC nas indústrias da área de estudo são a área de produção e a área de armazenagem, e que não há fontes relacionadas ao descarte ou disposição, esta informação parece estar inexata. O possível desvio pode estar relacionado ao processo de obtenção da informação, uma vez que as fichas não apontam o cumprimento da etapa de Avaliação Preliminar, que tem o melhor procedimento para definir uma fonte de contaminação.

\subsection{Resultados de Análises Químicas da Água}

Foram identificadas e reunidas análises químicas de EEC e EAC de 86 dos 513 poços outorgados, que resultaram em 46 detecções de EEC ou EAC, sendo 31 acima dos VOI (Figura 34). Havia mais de uma análise para alguns poços e foi considerada a análise de maior detecção.

A Figura 35 ilustra as ocorrências de EEC ou EAC relacionando-as com o VOI. Embora o CV ocorra em concentrações mais baixas, é o que mais ocorre acima dos valores de referência, por ser o mais tóxico e possuir o valor de referência mais restritivo entre estes compostos.

Pôde-se observar que o TCE ocorre com maior freqüência, seguido pelo PCE, CV e cis1,2-DCE (Tabela 10). Tanto as médias quanto as medianas, para os compostos PCE, cis-1,2DCE e CV, ocorreram acima do VOI. Para o TCE e o 1,1-DCE, as médias estiveram acima dos VOI. 


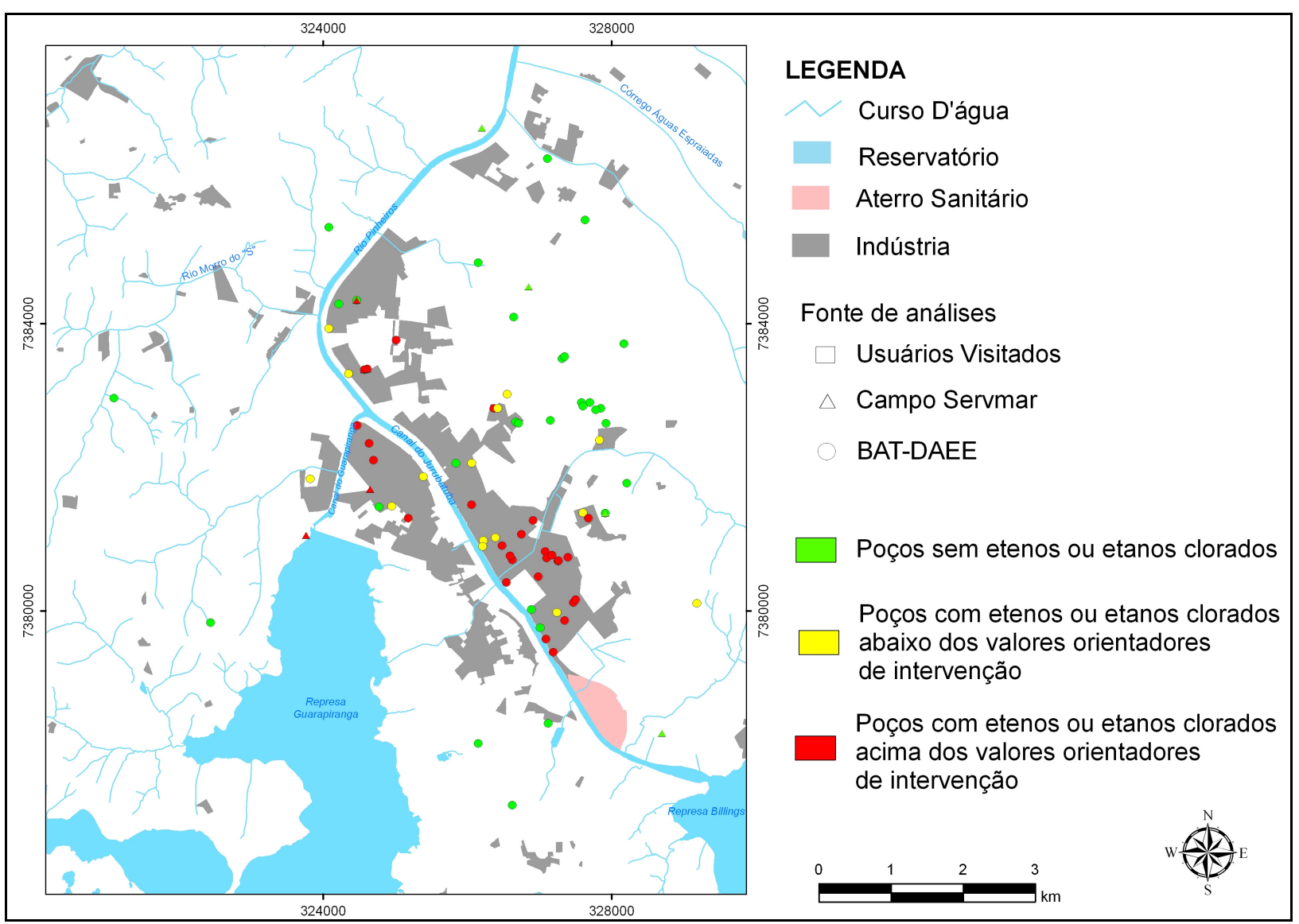

Figura 34 - Detecções de EEC ou EAC, relacionadas aos Valores Orientadores de Intervenção da CETESB.

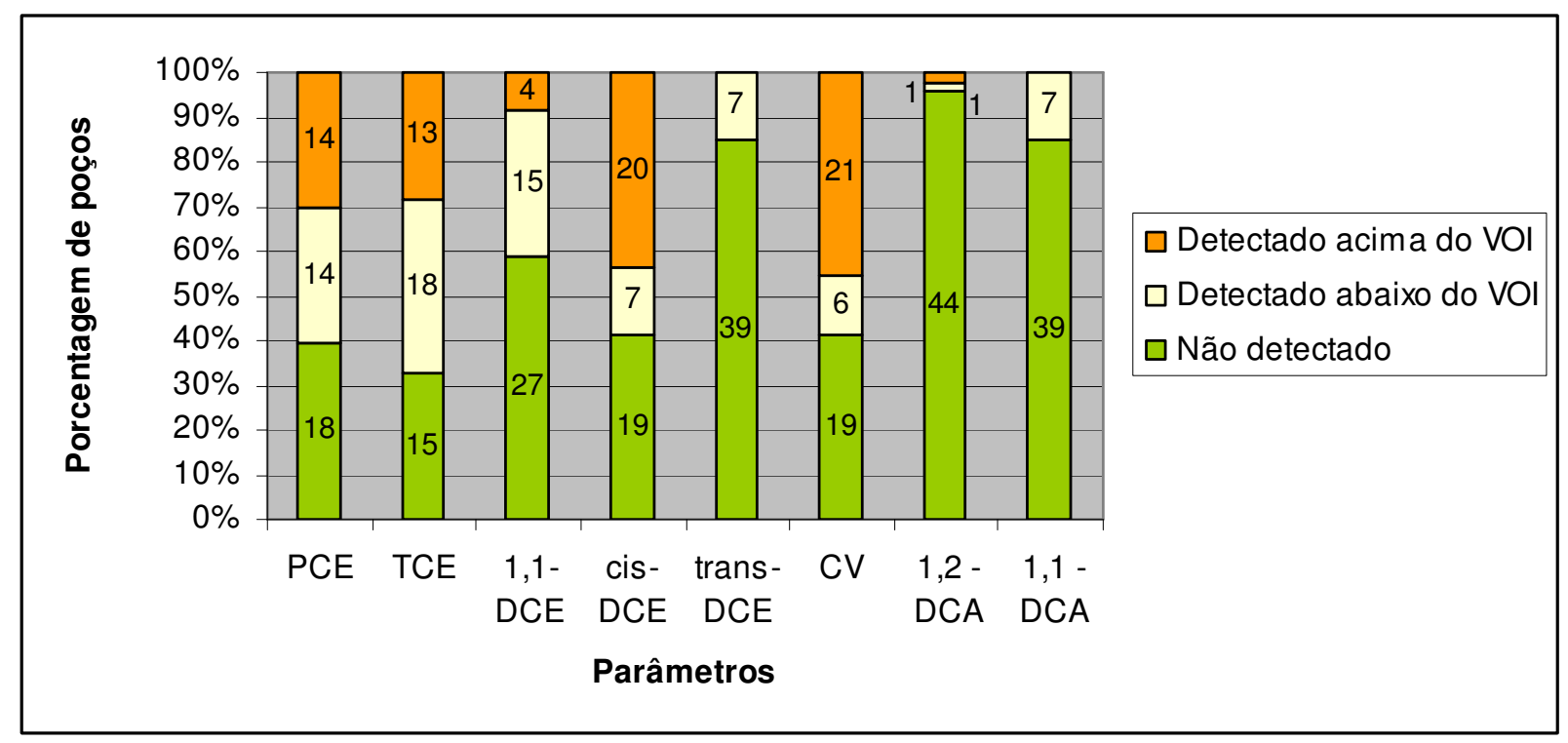

Figura 35 - Detecção de EEC ou EAC em 43 poços. 
Tabela 10 - Ocorrências e Concentrações de EEC e EAC em poços $(\mu \mathrm{g} / \mathrm{L})$.

\begin{tabular}{|l|r|r|r|r|r|r|r|r|}
\hline & PCE & TCE & $\begin{array}{c}\text { cis-1,2- } \\
\text { DCE }\end{array}$ & 1,1-DCE & $\begin{array}{c}\text { trans- } \\
\text { 1,2-DCE }\end{array}$ & CV & $\begin{array}{r}1,1- \\
\text { DCA }\end{array}$ & $\begin{array}{c}1,2- \\
\text { DCA }\end{array}$ \\
\hline Mínimo & 1,9 & 1,3 & 4,3 & 2,8 & 2,9 & 2,0 & 2,6 & 0,2 \\
\hline Média & 271,9 & 308,8 & 698,0 & 141,3 & 9,9 & 53,2 & 18,0 & 5,6 \\
\hline Mediana & 46,3 & 49,0 & 302,0 & 14,0 & 6,8 & 14,0 & 6,8 & 5,6 \\
\hline Máxima & $1.830,0$ & $2.200,0$ & $3.340,0$ & $1.534,0$ & 21,9 & 234,0 & 72,6 & 10,9 \\
\hline Deteç̧ões & 26 & 29 & 25 & 17 & 06 & 25 & 06 & 02 \\
\hline VOI & 40 & 70 & $(a)$ & 30 & $(a)$ & 5 & 280 & 10 \\
\hline
\end{tabular}

VOI: Valores Orientadores de Intervenção (CETESB, 2005)

(a): somatória para cis-1,2-DCE + trans-1,2-DCE $=50 \mu \mathrm{g} / \mathrm{L}$.

Segundo a USEPA (1998), normalmente, a degradação de TCE para DCE é mais comum para o isômero cis-1,2-DCE, seguido de trans-1,2-DCE e 1,1-DCE. Entretanto, pôde-se observar que, na área de estudos, ocorreu mais 1,1-DCE (17) do que trans-1,2-DCE (06).

A Tabela 11 apresenta todos os resultados de EEC e EAC considerados para cada um dos poços analisados. De um total de 9 poços amostrados no projeto DAEE-Servmar, foram detectados EEC e EAC em 5 poços.

Há ao menos 5 localidades, nos bairros Jardim São Luis, Socorro, Santo Amaro e Campo Grande, com ocorrências de PCE ou TCE (produtos possivelmente associados com a fonte da contaminação) em poços de produção distantes entre 1 e $2 \mathrm{~km}$ de áreas declaradas contaminadas por solventes halogenados. Isto pode apontar para ocorrência de áreas-fonte de contaminação, ainda não identificadas nas imediações destes poços. Por outro lado, deve-se atentar que determinadas condições de fraturamento podem favorecer a propagação de contaminantes por distâncias de unidades de quilômetros.

Com o objetivo de verificar ocorrências de contaminação em diferentes profundidades em poços de produção, foram selecionados 3 poços conhecidamente contaminados (poços 691, 692 e 1249) e aplicados isolamentos de trechos com o uso de obturadores pneumáticos. Este experimento permitiu observar que nos diferentes trechos, a distintas profundidades nos poços, ocorrem EEC e EAC. 


\begin{tabular}{|c|c|c|c|c|c|c|c|c|c|c|c|}
\hline \multicolumn{12}{|c|}{ Tabela 11 - Poços com EEC ou EAC ( $\mu \mathrm{g} / \mathrm{L})$. } \\
\hline ID & Poço & data & PCE & TCE & $\begin{array}{c}\text { cis-1,2- } \\
\text { DCE }\end{array}$ & 1,1-DCE & $\begin{array}{c}\text { trans- } \\
1,2-D C E\end{array}$ & CV & $\begin{array}{c}1,1,1- \\
\text { TCA }\end{array}$ & $\begin{array}{l}1,2- \\
\text { DCA }\end{array}$ & $\begin{array}{l}1,1- \\
\text { DCA }\end{array}$ \\
\hline 1 & 1374 & ago-05 & 1.830 & 570 & 2.920 & 8 & 7 & 181 & & & \\
\hline 2 & 7380697N.327255E* & & 51 & 16 & 2.810 & 9 & 6 & 234 & & & 4 \\
\hline 3 & 7380746N.327396E & & 20 & 18 & 560 & & & 11 & & & \\
\hline 4 & 7380703N.327264E & & 3 & 15 & 2.170 & & & 10 & & & \\
\hline 5 & 7380697N.327255E & & & & 293 & 3 & & & & & \\
\hline 6 & 1346 & mar-05 & 775 & 446 & 3.340 & 9 & 7 & 194 & & & 3 \\
\hline 7 & 514 & out-05 & 6 & 6 & 10 & & & & & & \\
\hline 8 & 71 & ago-05 & 123 & 28 & 181 & & & 23 & & & \\
\hline 9 & 204 & ago-05 & 3 & & 416 & & & 39 & & & \\
\hline 10 & 266 & ago-05 & & & 244 & & & 43 & & & \\
\hline 11 & 325 & ago-05 & 7 & 3 & 332 & & & 37 & & & \\
\hline 12 & 710 & ago-05 & & 312 & 108 & & & & & & \\
\hline 13 & 1303 & ago-05 & 163 & 2.200 & 730 & 498 & 22 & 10 & & & 73 \\
\hline 14 & 1540 & ago-05 & 42 & 16 & 45 & & & 2 & & & \\
\hline 15 & 1394 & ago-05 & 1.630 & 273 & 1.000 & 6 & 3 & 115 & & & 3 \\
\hline 16 & 1425 & jun-07 & 6 & 2 & 4 & & & & & & \\
\hline 17 & 217 & abr-04 & 9 & 3 & & & & & & & \\
\hline 18 & 7380110N.329180E & out-05 & 2 & & & & & & & & \\
\hline 19 & 390 & ago-05 & & & 13 & & & & & & \\
\hline 20 & 1401 & ago-05 & 26 & 1.770 & 32 & 14 & & & & & \\
\hline 21 & 7381870 N.325390E & fev-05 & & 1 & & & & 5 & & & \\
\hline 22 & 194 & nov-05 & & & & & & 4 & & & \\
\hline 23 & 1501 & jun-04 & & & & 10 & & 2 & & & \\
\hline 24 & 1503 & jun-04 & & & & 9 & & & & & \\
\hline 25 & $7382060 \mathrm{~N} .326060 \mathrm{E}$ & out-05 & & & & 3 & & 4 & & & \\
\hline 26 & 281 & out-05 & 6 & 4 & & & & & & & \\
\hline 27 & 178 & fev-07 & & 213 & 189 & & & & & & \\
\hline 28 & 311 & mar-05 & & 4 & 555 & 58 & 15 & 14 & & & 9 \\
\hline 29 & 312 & mar-05 & 477 & 307 & 507 & 24 & & 15 & & 11 & 16 \\
\hline 30 & 1368 & set-05 & 4 & & & & & 9 & & & \\
\hline 31 & 381 & & & 1.868 & & 19 & & 9 & & & \\
\hline 32 & 912 & dez-05 & 358 & 83 & 302 & & & & & & \\
\hline 33 & 913 & dez-05 & 67 & & 413 & & & & & & \\
\hline 34 & 218 & set-05 & 89 & & & & & & & & \\
\hline 35 & 174 & out-05 & 687 & 212 & 263 & 17 & & 11 & & & \\
\hline 36 & 7380480 N.326980E & ago-05 & 38 & 145 & & & & 135 & & 1 & \\
\hline 37 & 1502 & jun-04 & & & & 21 & & 3 & & & \\
\hline 38 & 7383930N.324080E & & & & 13 & & & & & & \\
\hline 39 & 397 & out-05 & & 49 & & & & & & & \\
\hline 40 & 144 & out-05 & & 71 & & & & & & & \\
\hline 41 & 1683 & mar-07 & & 5 & & & & & & & \\
\hline 42 & 691 & mai-08 & 20 & 13 & 126 & 71 & 5 & 88 & & & 35 \\
\hline 43 & 692 & mai-08 & 129 & 94 & 701 & 684 & 20 & 375 & 5 & & 425 \\
\hline 44 & 1249 & mai-08 & & 6 & 24 & 15 & & 37 & & & \\
\hline 45 & 1618 & jun-08 & & 1 & 79 & & & & & & \\
\hline \multirow[t]{2}{*}{46} & 1591 & jun-08 & 10 & 16 & 1.369 & 28 & 19 & 285 & & & 5 \\
\hline & & VOI & 40 & 70 & (a) & 30 & (a) & 5 & 280 & 10 & 280 \\
\hline
\end{tabular}

ID - Identificação amostra

1830 - concentração acima dos Valores Orientador de Intervenção (VOI) para a água subterrânea (CETESB, 2005)

8 - concentração abaixo do VOI

* Poços sem numeração no cadastro do DAEE foram identificados pelas suas coordenadas

(a): somatória para cis-1,2-DCE + trans-1,2-DCE $=50 \mu \mathrm{g} / \mathrm{L}$. 
No poço 691 (Figura 36) as concentrações são muito baixas na profundidade mais rasa, logo na primeira entrada de água do poço, tornando-se mais altas conforme aumenta-se o trecho amostrado. Isso pode indicar que a contaminação não é local e provavelmente seja proveniente de fluxos laterais horizontais. A porção amostrada a $96 \mathrm{~m}$ para cima apresenta as maiores concentrações e a partir dessa profundidade a concentração diminui, sendo, em geral, menores nas fraturas amostradas isoladamente. Durante os ensaios com obturadores, observou-se que o fluxo na porção mais rasa obturada é ascendente e, em todos os outros trechos, o sentido de fluxo é ascendente, consolidando a interpretação de que a contaminação tem origens distantes do poço e provém de fluxos laterais horizontais.

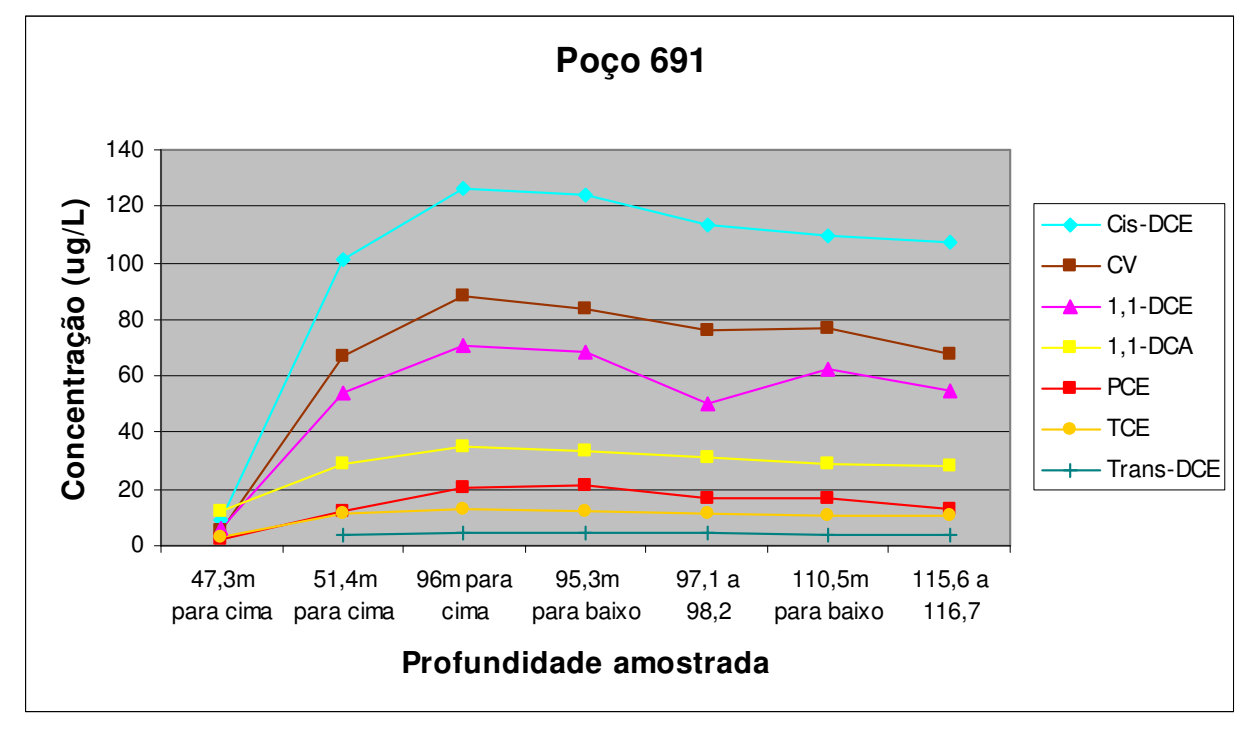

Figura 36 - Concentração de parâmetros em diferentes profundidades amostradas.

No poço 692 (Figura 37) foram realizadas três amostragens em diferentes profundidades. Duas amostragens separam o poço em uma zona mais rasa e outra mais profunda. A terceira amostragem foi de um trecho específico aos $96 \mathrm{~m}$ de profundidade. $\mathrm{O}$ trecho mais profundo (a partir dos $49 \mathrm{~m}$ de profundidade) apresentou concentrações ligeiramente mais altas do que as do trecho superior. O trecho específico, posicionado em uma fratura aos 96 metros de profundidade, apresentou as menores concentrações detectadas.

No poço 692, foi detectado o TCA, um EAC que não havia ocorrido em todo o histórico de análises preexistentes, embora tenha ocorrido o 1,1-DCA, produto de degradação do TCA. O TCA foi detectado apenas na porção superior e o 1,1-DCA foi detectado nos três trechos amostrados. Os fluxos são ascendentes e, em geral, as concentrações dos compostos nas porções inferior e superior do poço são parecidas, não auxiliando em interpretações sobre as origens da contaminação. 


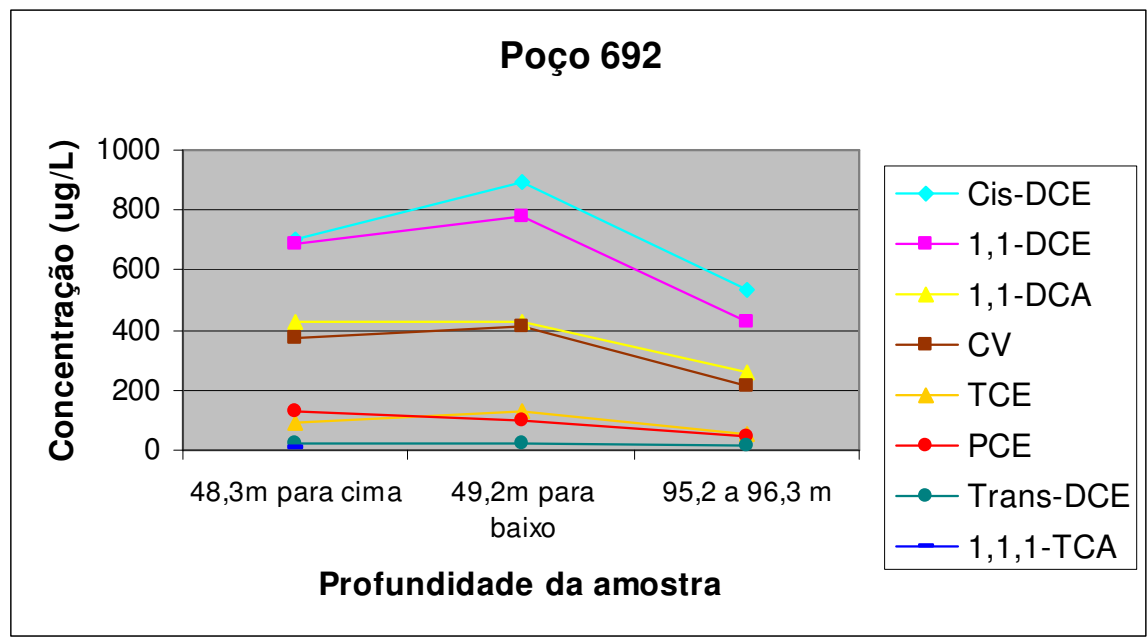

Figura 37 - Concentração de parâmetros em diferentes profundidades amostradas.

No poço 1249 (Figura 38), as maiores concentrações de PCE, TCE e 1,1-DCE ocorrem no trecho mais raso (menor do que $38 \mathrm{~m}$ ). Já as maiores concentrações de cis-1,2-DCE e CV, ocorrem no trecho seguinte (menor do que $45 \mathrm{~m}$ ). Nos trechos mais profundos do que $87 \mathrm{~m}$, ocorrem apenas cis-1,2-DCE e CV. Tais constatações são indicativas de uma origem local da contaminação, que está na porção rasa. Não houve indicação sobre o sentido de fluxo vertical nos três níveis mais rasos obturados. Já nos dois níveis inferiores, o sentido de fluxo apontado é descendente.

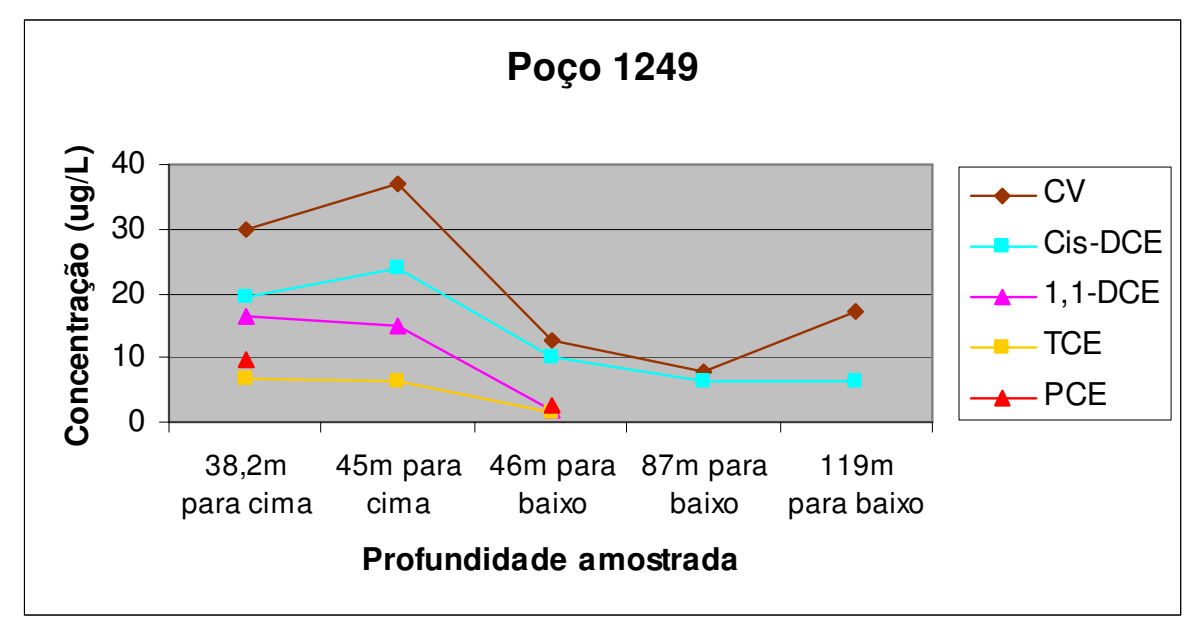

Figura 38 - Concentração de parâmetros em diferentes profundidades amostradas. 


\subsection{Considerações Adicionais Sobre o Cenário de Contaminação}

Embora o histórico de contaminação por organoclorados na área de estudo tenha sido evidenciado destacando-se duas ou mais indústrias contaminadoras e, apenas 17 indústrias estejam declaradas contaminadas por EEC ou EAC pela CETESB, a distribuição ampla e dispersa das Áreas Contaminadas Declaradas pela CETESB e o número de ocorrências de poços de produção contaminados indicam que a contaminação provém de múltiplas fontes, conforme já havia sido apontado pela própria CETESB.

Verificou-se a ocorrência de EEC e EAC em poços adjacentes, continuamente, que pode caracterizar um extenso conjunto de plumas (Figura 34). Estas plumas, provavelmente, estão associadas a fontes múltiplas, que muitas vezes se sobrepõem. A extensão da contaminação é coincidente com a direção do canal do Jurubatuba e ocorre às margens do canal, desde as imediações do Aterro Santo Amaro (ao sul) até os primeiros quilômetros do rio Pinheiros (ao norte), alargando-se também às margens do canal da Guarapiranga. A extensão atual conhecida, da área de ocorrência deste conjunto de plumas de contaminação, é de aproximadamente $6 \mathrm{~km}$ de comprimento e $3,5 \mathrm{~km}$ de largura.

São necessários estudos locais detalhados para definir as fontes e respectivos limites espaciais de cada uma destas plumas de contaminação para auxiliar na distribuição de responsabilidades sobre o gerenciamento das áreas contaminadas. Quanto mais estes limites estiverem sobrepostos entre si, maior será a necessidade de gestores públicos e associações industriais definirem, intermediarem e gerenciarem as ações para a recuperação das áreas.

Caso os limites destas plumas de contaminação sobreponham-se entre si formando uma grande pluma de contaminação, a fonte de contaminação pode ser classificada como fonte não-pontual, reforçando a necessidade do gerenciamento ser realizado em escala regional.

Deve-se atentar que há limitações do conhecimento integrado sobre a distribuição da contaminação também por causa da variação de profundidades dos poços, por causa das diferentes datas de amostragem consideradas e, porque a ocorrência de quaisquer EEC ou EAC de interesse neste trabalho já foi suficiente para considerar a presença de contaminação em um ponto. Estas limitações podem comprometer conclusões sobre a distribuição da contaminação, o que poderá ser melhor detalhada com o aumento da rede de monitoramento.

A profundidade da contaminação é um dado difícil de obter, pelo fato de estar vinculada à profundidade perfurada dos poços, uma vez que os poços podem ser os próprios propagadores da contaminação para outras zonas do aqüífero. Isto pôde ser observado com os ensaios realizados com obturadores pneumáticos, que mostraram fluxos descendentes e ascendentes nos poços ensaiados. 
Com o bombeamento dos poços, ocorre o rebaixamento do nível d'água e forma-se um cone de depressão, propiciando uma inversão do fluxo subterrâneo e um aumento da infiltração de água em direção ao poço. Isto favorece a chegada do contaminante ao poço, diferentemente de um simples poço de monitoramento que seria um ponto de observação mais representativo do aqüífero.

Deve-se destacar ainda, que a área de restrição temporária, referente à Portaria DAEE 1594, condicionou o universo de poços amostrados para os parâmetros de interesse, bem como que os dados fora dela são escassos. Assim, deve-se considerar que a falta de dados às margens do rio Pinheiros não permite definir com segurança onde estão os limites das plumas de contaminação. De cinco amostras que foram obtidas fora dos limites de restrição provisória, apenas em duas foram detectados EEC.

Observa-se uma maior concentração de poços contaminados ao longo da Avenida Eusébio Steveux. Isto pode estar relacionado ao fato de ser a região onde há o maior número de poços analisados. E também pelo fato da contaminação ter sido observada inicialmente e, portanto, perseguida naquelas imediações.

Outra questão é que a contaminação se dilui ao longo de toda a coluna d'água de um poço. Considerando-se as concentrações de EEC dissolvidos na água dos poços de monitoramento, em Áreas Contaminadas Declaradas, da ordem de dezenas e, até de centenas de miligramas por litro e comparando-as às detectadas em poços de produção, verifica-se detecções cerca de cem vezes maiores nos poços de monitoramento, pois os poços de produção possuem profundidades maiores e, por isso, captam vários níveis do aqüífero, contaminados e não contaminados, diluindo a contaminação.

Como o poço de produção recebe água em uma fratura e perde em outra, pode transmitir massa de contaminantes para diferentes pontos do aqüífero. Estas maiores massas de contaminantes podem atingir o poço por fraturas principais melhor interligadas às origens dos contaminantes.

Considerando a carga contaminante potencial, apontada neste estudo e a necessidade de conhecer origens das contaminações que atingem os poços de produção, é possível que estudos sejam direcionados, tanto à investigação das áreas fontes primárias e secundárias, quanto à expansão do monitoramento e, conseqüentemente, à tomada de ações para a recuperação e o controle da contaminação existente, principalmente nas zonas rasas do aqüífero, onde o trabalho de recuperação é viável. 


\section{RESTRIÇÃO E CONTROLE DE USO DE ÁGUA SUBTERRÂNEA}

Para traçar áreas de restrição e controle de uso das águas subterrâneas, foram considerados os diversos aspectos técnicos tratados nos estudos hidrogeológicos, na compilação de resultados de análises químicas, na identificação e classificação de Áreas de Elevado Potencial de Contaminação (AEPC) e na identificação das áreas contaminadas com solventes halogenados, declaradas pela CETESB.

A definição destas áreas de restrição foi conceituada sob a aplicação de uma metodologia, pela qual a área é discretizada em pequenas subáreas onde são apontados os elementos de interesse ao problema existente e, com isso, pode-se visualizar zonas mais críticas para as quais podem ser priorizadas ações mais consistentes e efetivas de restrição e controle.

\subsection{Critérios para a Definição das Áreas de Restrição}

Os critérios adotados para o desenvolvimento da metodologia das áreas de restrição seguiram a aplicação dos passos abaixo enumerados.

1) Inicialmente, a área total foi dividida em células de $500 \mathrm{~m} \times 500 \mathrm{~m}$, permitindo reunir dentro de uma pequena área os elementos de interesse importantes para orientar decisões e possibilitar pré-estabelecer contornos, ou seja, os próprios contornos de células, que significarão os limites de áreas restritas.

A divisão de células nesta escala espacial é, aproximadamente, concordante com o deslocamento advectivo da água subterrânea, num tempo trânsito de 10 anos, aplicando-se a Lei de Darcy e corrobora com a Resolução nํ 3/2006, Art. 3ํ, quanto à orientação de observar a ocorrência de áreas contaminadas no entorno de $500 \mathrm{~m}$ de poços de produção.

2) Em cada célula foram identificados as AEPC (Figura 39);

3) De acordo com a distribuição espacial das AEPC nas grades, as células foram classificadas em menor, intermediária e maior densidade (Figura 40), de acordo com a seguinte divisão:

a) menor densidade: de 1 a 5 AEPC;

b) intermediária densidade: de 6 a 15 AEPC;

c) maior densidade: maior do que 15 AEPC.

4) Em cada célula foram identificados os seguintes elementos de interesse:

a) Atividades com Elevado Potencial de Contaminação (AEPC);

b) Poços com ocorrência de EEC e EAC;

c) Áreas declaradas contaminadas. 


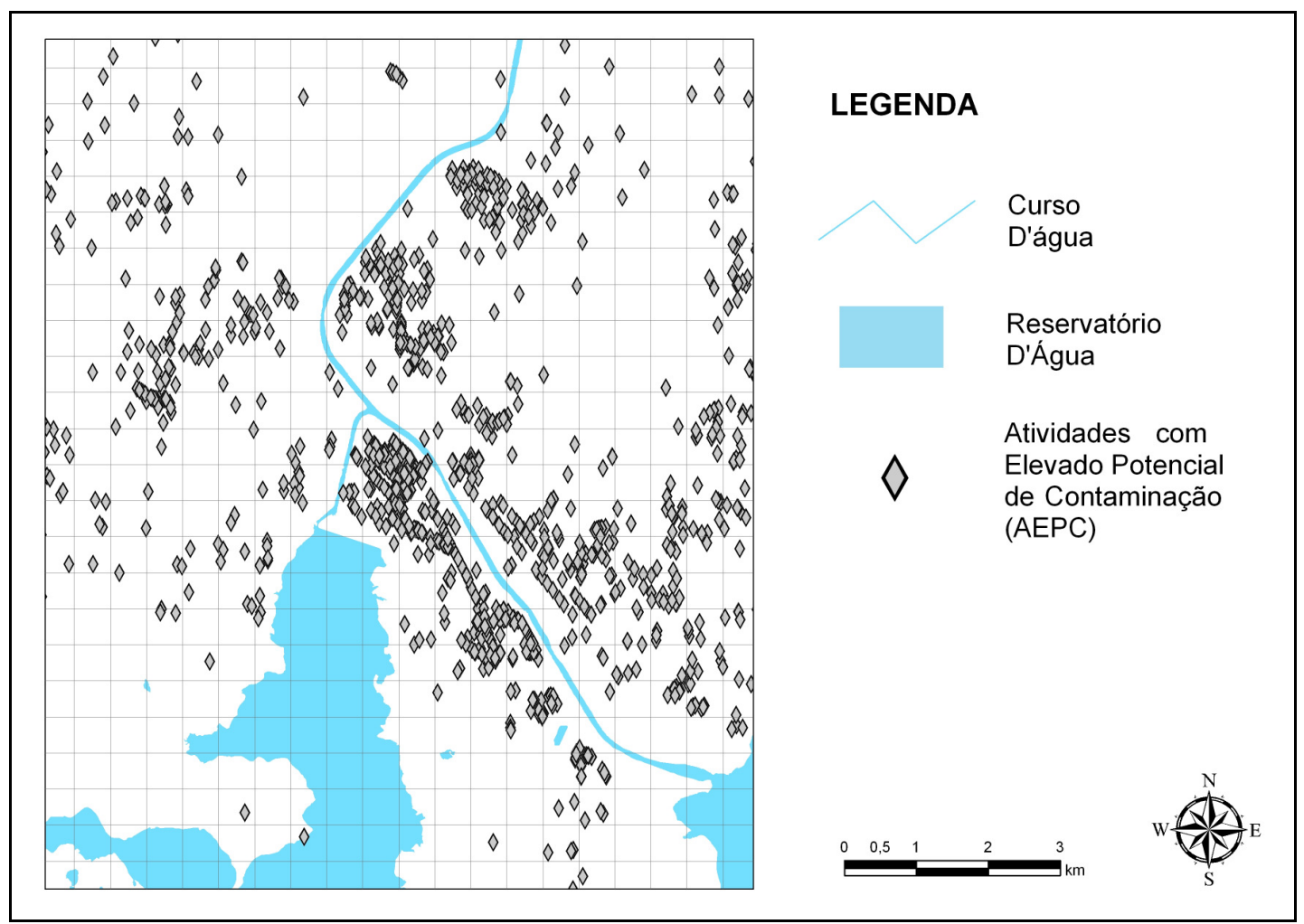

Figura 39 - Pontos de ocorrência de AEPC na grade de 500 m x 500 m.

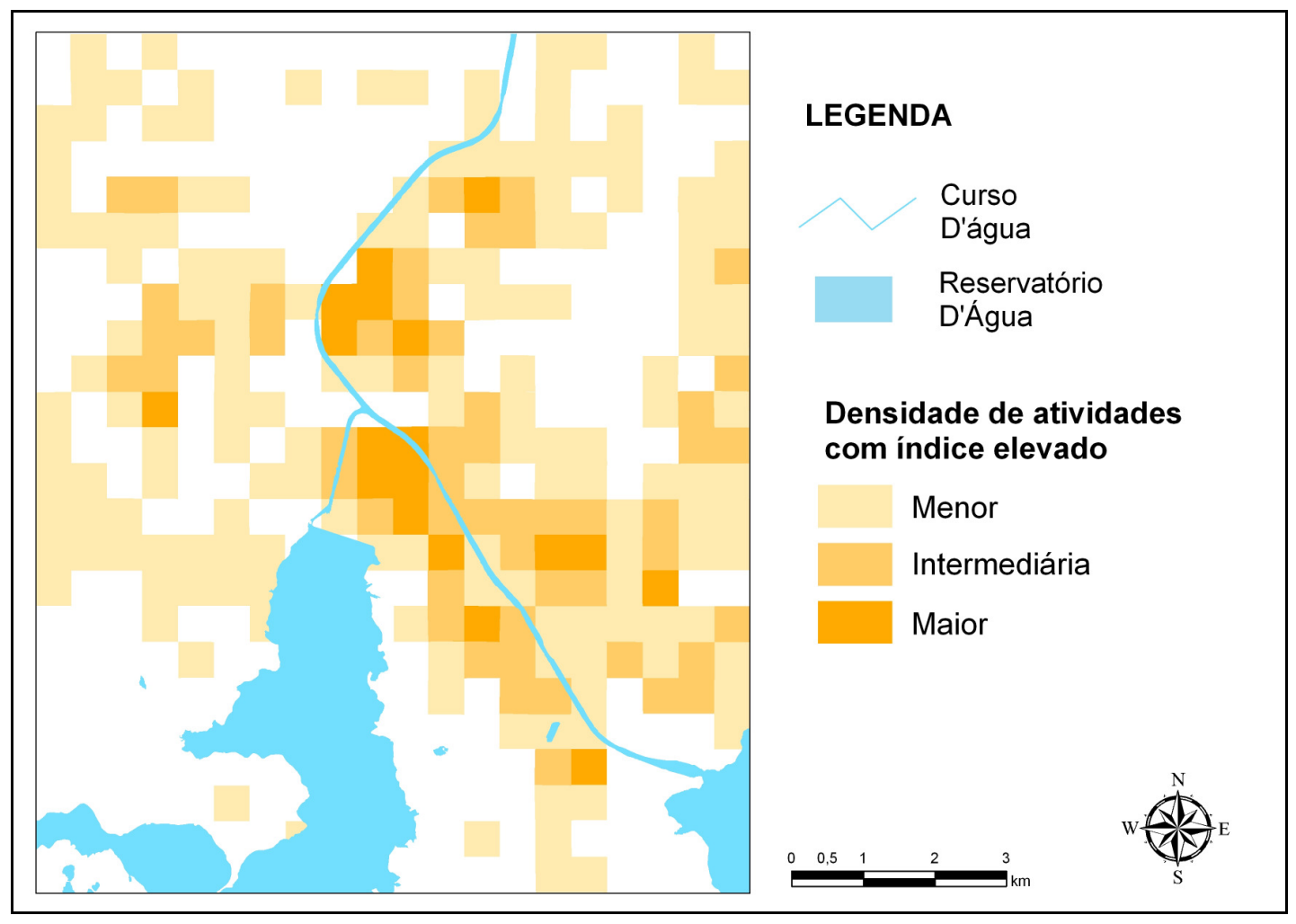

Figura 40 - Distribuição de Densidade de AEPC. 
A Figura 41 ilustra a freqüência de ocorrência dos intervalos de densidade de ocorrência de AEPC, sob os quais as células foram discretizadas em classes de menor, intermediária e maior densidade. Observa-se que 52\% não apresentaram AEPC, 32\% apresentaram de 1 a 5; 12\% apresentaram de 6 a 15 e 4\% apresentaram de 16 a 58 AEPC.

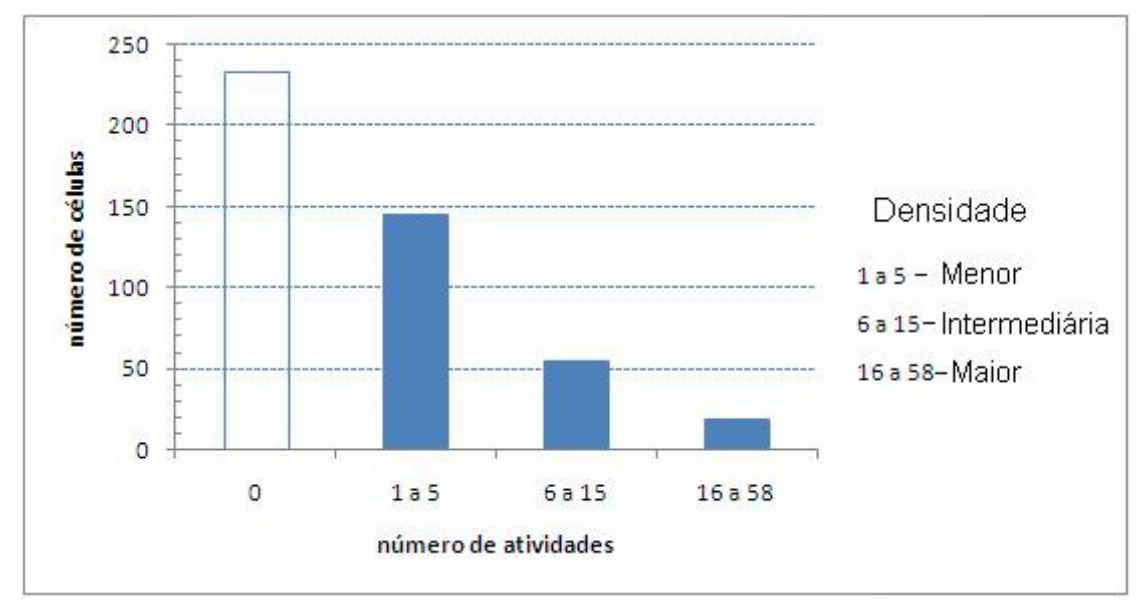

Figura 41 - Densidade de Áreas com Elevado Potencial de Contaminação (AEPC) nas células de $500 \mathrm{~m} \times 500 \mathrm{~m}$.

5) Foram definidas Células-Guia com o critério de apresentarem ao menos um entre os principais elementos de interesse para a definição de áreas de restrição. Estes elementos são: maior densidade de AEPC, poço com EEC ou EAC e área declarada contaminada com EEC ou EAC (Figura 42). Estas Células-guia constituem a própria Área de Alta Restrição.

6) Considerando-se as células-guia e o fluxo de água subterrânea, desenvolveu-se o conceito de proteção de célula vizinha para a célula a jusante da célula-guia. Seria um caso onde não há bombeamento e a célula vizinha seria contaminada por conta do fluxo natural da água subterrânea. Ao ponderar-se que o bombeamento provoca inversões de fluxo de água subterrânea, estendeu-se o conceito de proteção de células vizinhas a todas as células do entorno de uma célula-guia. Ou seja, o bombeamento da célula vizinha a montante fará acontecer a inversão do sentido do fluxo. Assim, assumiu-se que os poços situados em células vizinhas às células-guia encontram-se sob maiores riscos de produzir água contaminada (Figura 43). 


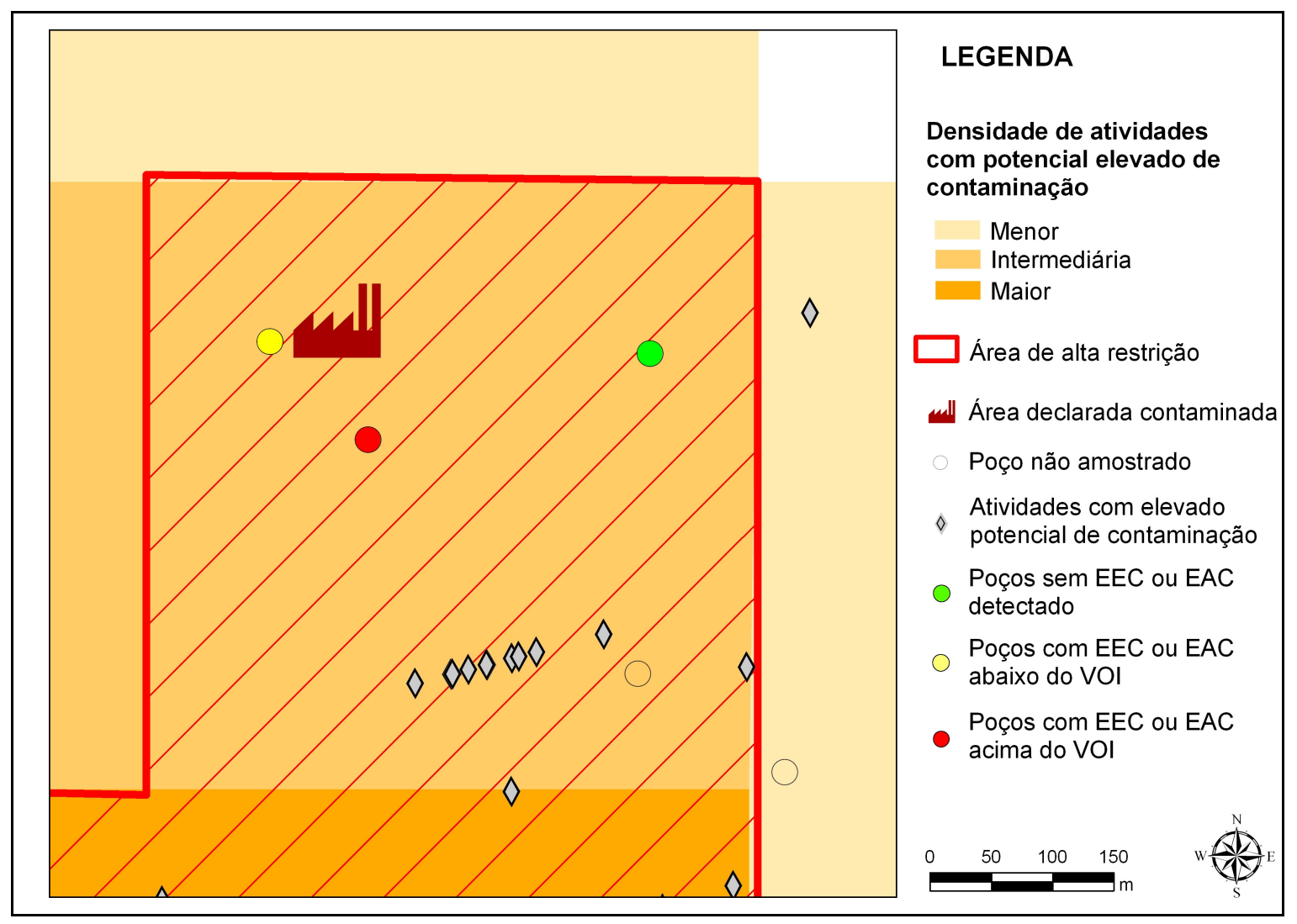

Figura 42 - Elementos para a definição da área de restrição.

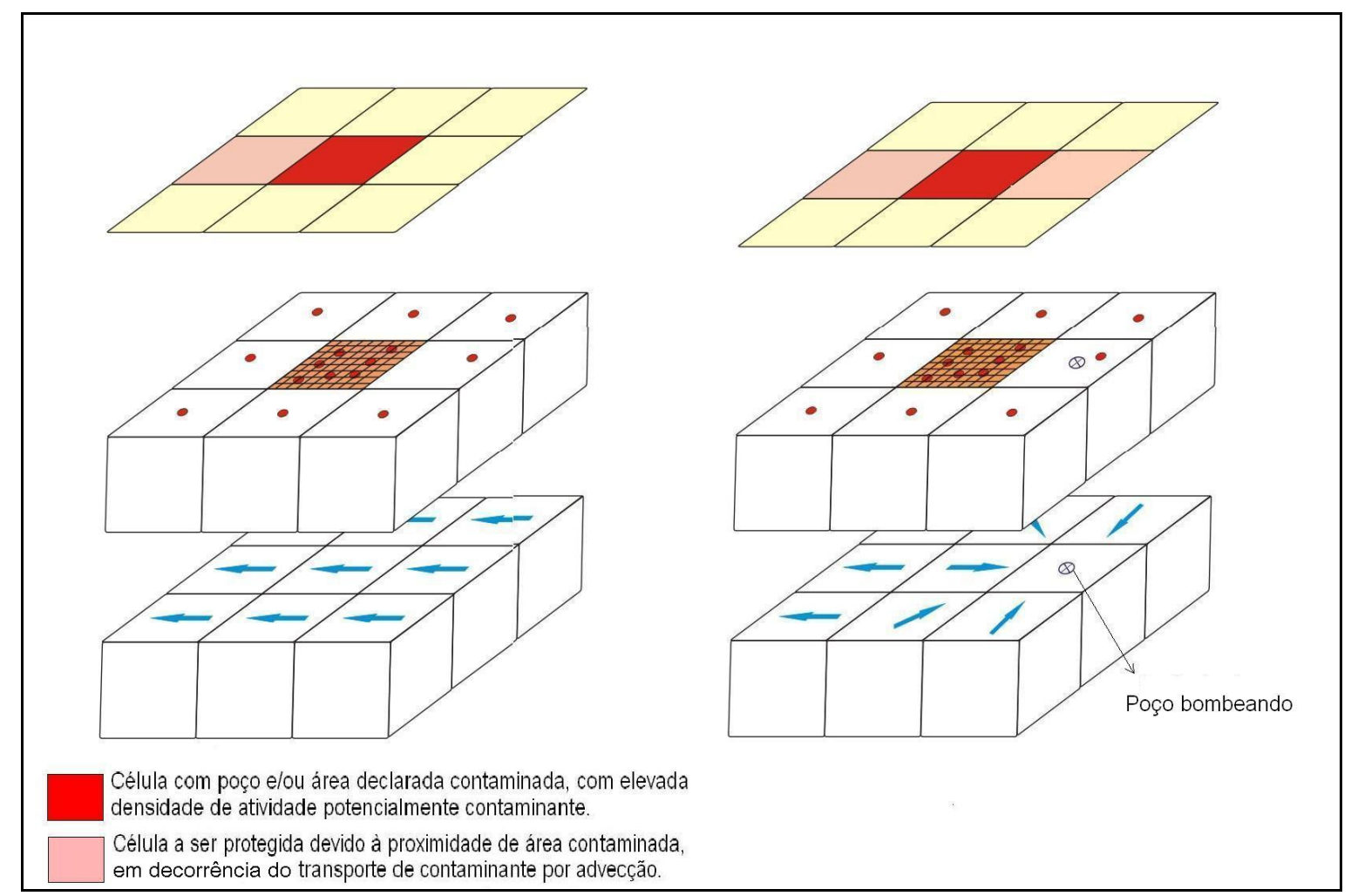

Figura 43 - Modelo conceitual de delimitação da área de restrição no entorno de células. 
A partir deste conceito, foi definido que as células do entorno de uma célula guia demarcariam os traçados da Área de Média Restrição. A Área de Baixa Restrição obedeceu ao mesmo conceito, entretanto sendo definida pelas células do entorno de uma célula de intermediária densidade de ocorrência de AEPC. A Figura 44 exibe a configuração dos traçados de áreas de restrição.

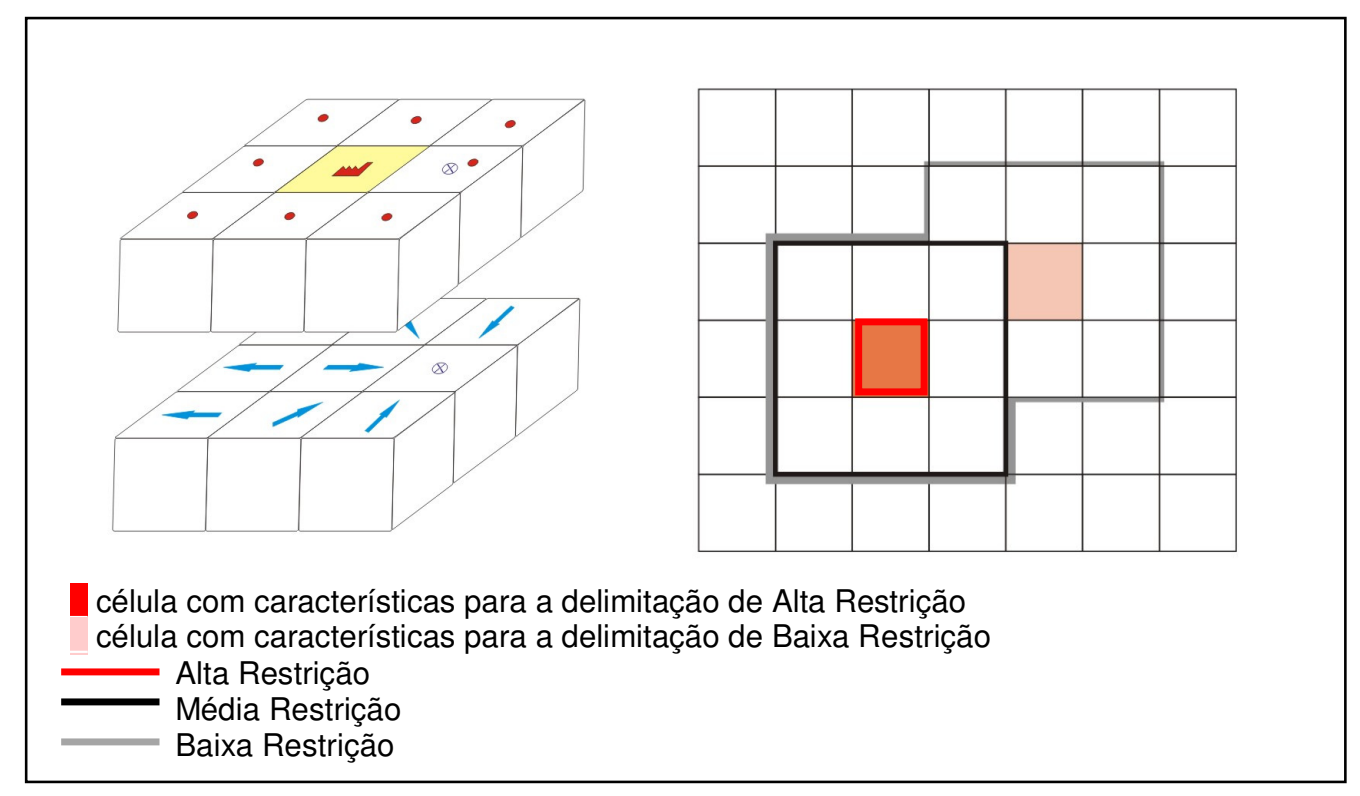

Figura 44 - Configuração dos traçados de áreas de restrição.

7) Desta forma, a partir dessa repartição e dos critérios adotados, dividiu-se a área de estudo em três áreas de restrição de uso e captação da água subterrânea entre Alta, Média e Baixa Restrição, como seguem abaixo:

a) Alta Restrição - áreas de maior densidade de AEPC, poço com EEC ou EAC ou área declarada com EEC ou EAC. Está concentrada à margem direita do rio Pinheiros e ao redor dos canais do Jurubatuba e Guarapiranga, abrangendo uma área de 10,75 km².

b) Média Restrição - área definida para proteger as áreas representadas pelas células do entorno de células de Alta Restrição, considerando-se o modelo conceitual de fluxo e transporte de contaminantes por advecção. Abrange $31 \mathrm{~km}^{2}$ ao redor das áreas de alta restrição.

c) Baixa Restrição - área definida para proteger células de intermediária densidade de AEPC e as células de seu entorno, abrangendo $18 \mathrm{~km}^{2}$.

A área de Alta Restrição proposta com esta metodologia apresenta níveis de restrição semelhantes aos determinados pelo DAEE através da Portaria 1594. Entretanto, o tamanho da área de restrição provisória inicialmente implantada é de $32 \mathrm{~km}^{2}$ e o tamanho da área de Alta Restrição, proposta com este trabalho, é de 10,75 km². 
As áreas de baixa e média restrição, para as quais se propõe a possibilidade de utilizar a água subterrânea, somam juntas $41 \mathrm{~km}^{2}$, o que corresponde a cerca de $80 \%$ da área total de restrição proposta $\left(51,75 \mathrm{~km}^{2}\right)$.

A Figura 45 apresenta a configuração das áreas de restrição sobre a área de estudos. O Mapa 3 apresenta todos os elementos de interesse para os traçados das áreas de restrição, bem como o contorno de cada área.

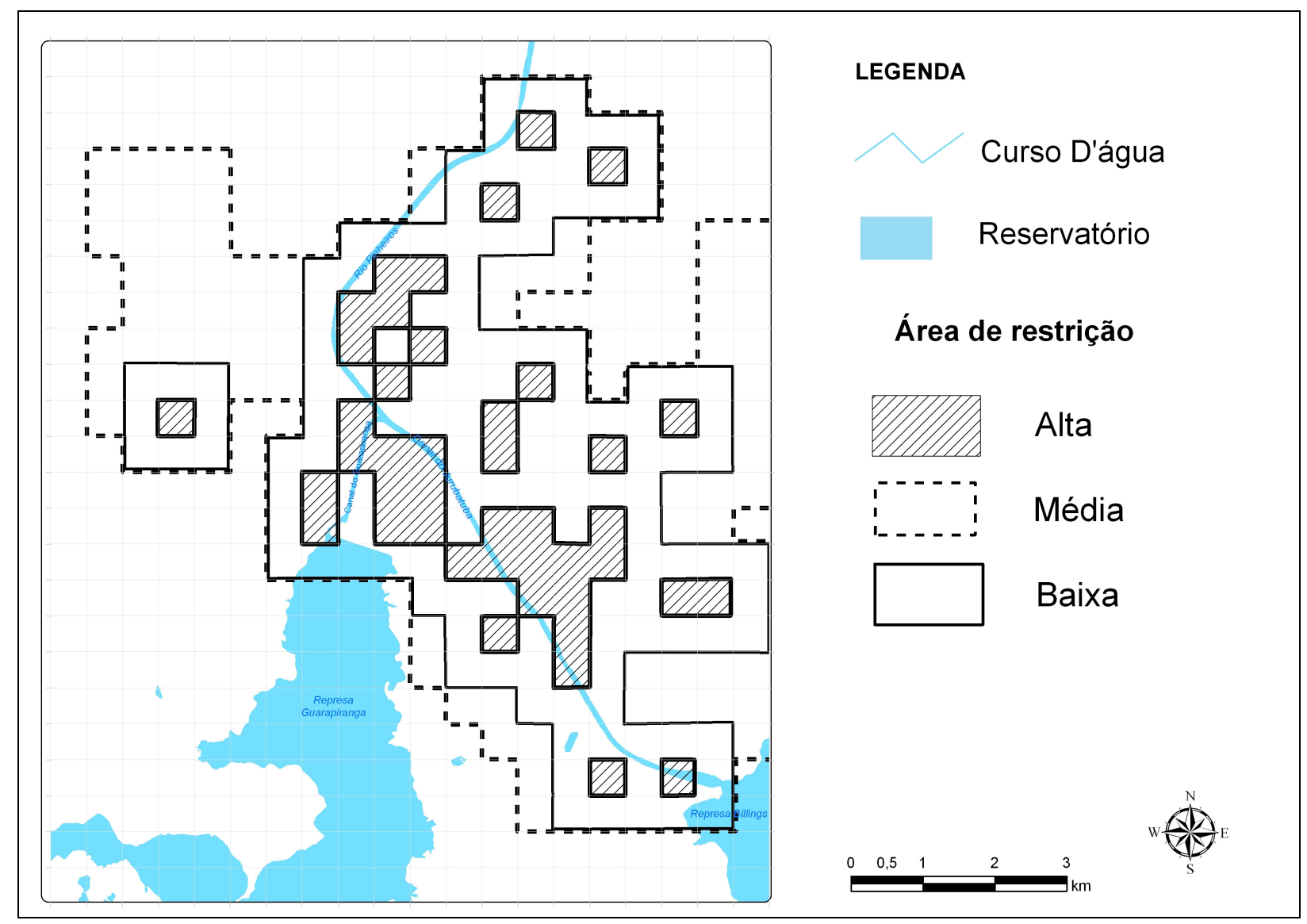

Figura 45 - Conformação final das Áreas de Restrição.

A constatação da informação sobre qual é o nível de restrição, entre nenhum e alto, em que um poço se encontra, na área de estudos, é facilmente verificada uma vez que, tanto o mapa, quanto os poços, possuem dados de coordenadas, bastando, portanto, plotar o poço no mapa e visualizar em que área o poço se localiza. 


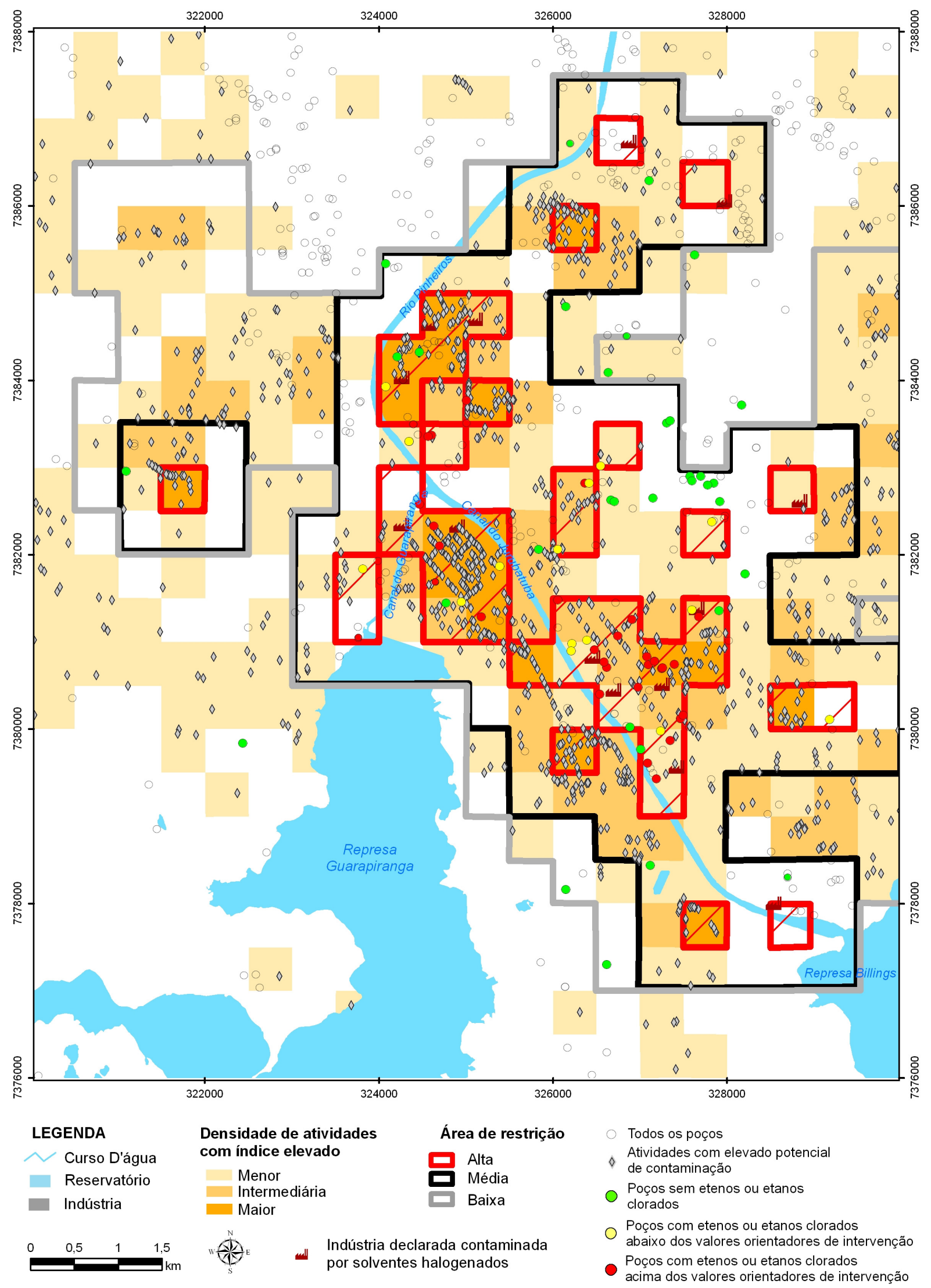

Mapa 3 - Elementos de interesse e Áreas de Restrição e Controle de Uso de Água Subterrânea 


\subsection{Medidas de Restrição e Controle de Uso de Água Subterrânea}

Para as três áreas de restrição definidas são propostas medidas de restrição e controle distintos, conforme o nível de restrição em que se enquadra. Resumidamente, os controles propostos no estudo para as diferentes áreas de restrição, são:

1) na área de Alta Restrição, monitoramentos periódicos nos poços não contaminados e tamponamento de poços com detecção de EEC ou EAC;

2) nas áreas de Média e Baixa restrição, monitoramentos periódicos;

3) para poços clandestinos, regularização de outorga;

4) para poços abandonados, tamponamento adequado;

5) para poços futuros, permissão apenas na área de Baixa Restrição.

A Tabela 12 descreve, de maneira esquemática, as orientações de controle propostas para cada nível de restrição, considerando-se cada uma das condições previstas em que um poço possa se encontrar.

Os programas de amostragem e monitoramento periódicos poderiam ser direcionados aos compostos de interesse definidos neste trabalho, que determinam uma contaminação regional. Assim poder-se-ia diminuir custos de laboratórios viabilizando a participação dos usuários de água. Seriam previstas análises dos EEC (PCE; TCE; cis-1,2-DCE; 1,1-DCE; trans1,2-DCE e CV) e os EAC (TCA; 1,2-DCA e 1,1-DCA). Poderia ser desenvolvido um plano de monitoramento padrão que instruísse sobre os procedimentos de coleta e informasse sobre 0 credenciamento de laboratórios para a realização dessas análises. Tendo um formato padrão os resultados seriam uniformes favorecendo a alimentação de uma base de dados unificada.

Para o melhor conhecimento e controle dos aqüíferos e da rede de poços de produção, o ideal seria que os poços passassem por um processo de adequação, que contivesse:

- Hidrômetro;

- Tubo Guia para medição de nível de água;

- Dispositivo para amostragem logo após hidrômetro;

- Medições atualizadas de níveis estáticos e dinâmicos;

- Teste atualizado para determinação de vazão ótima;

- Fotografia da Proteção Sanitária;

- Apresentação de plano de amostragem periódica.

Para que este processo de adequação fosse efetivo, a readequação poderia ficar associada à solicitação de obtenção ou renovação de outorga. 
Tabela 12- Medidas de restrição e controle para os poços de produção.

\begin{tabular}{|c|c|c|c|}
\hline \multirow{2}{*}{$\begin{array}{l}\text { CONDIÇÃO DO POÇO } \\
\text { DE PRODUÇÃO }\end{array}$} & \multicolumn{3}{|c|}{ RESTRIÇÃO } \\
\hline & ALTA & MÉDIA & BAIXA \\
\hline $\begin{array}{l}\text { Com etenos clorados ou } \\
\text { etanos clorados acima } \\
\text { ou abaixo dos Valores } \\
\text { Orientadores de } \\
\text { Intervenção (1) }\end{array}$ & Tamponamento & Torna-se Alta Restrição & Torna-se Alta Restrição \\
\hline $\begin{array}{l}\text { Sem detecção de etenos } \\
\text { clorados ou etanos } \\
\text { clorados }\end{array}$ & $\begin{array}{l}\text { Monitoramento } \\
\text { trimestral para etenos } \\
\text { clorados ou etanos } \\
\text { clorados. Uso da água é } \\
\text { permitido, exceto para } \\
\text { os Usos } \\
\text { Preponderantes }\end{array}$ & $\begin{array}{l}\text { Monitoramento } \\
\text { trimestral de etenos } \\
\text { clorados ou etanos } \\
\text { clorados }\end{array}$ & $\begin{array}{l}\text { Monitoramento } \\
\text { semestral de etenos } \\
\text { clorados ou etanos } \\
\text { clorados. }\end{array}$ \\
\hline $\begin{array}{l}\text { Sem conhecimento de } \\
\text { análise de etenos } \\
\text { clorados ou etanos } \\
\text { clorados }\end{array}$ & $\begin{array}{l}\text { Monitoramento } \\
\text { trimestral para etenos } \\
\text { clorados ou etanos } \\
\text { clorados. Uso da água é } \\
\text { permitido, exceto para } \\
\text { os Usos Preponderantes }\end{array}$ & $\begin{array}{l}\text { Monitoramento } \\
\text { trimestral de etenos } \\
\text { clorados ou etanos } \\
\text { clorados. }\end{array}$ & $\begin{array}{l}\text { Monitoramento } \\
\text { semestral de etenos } \\
\text { clorados ou etanos } \\
\text { clorados. }\end{array}$ \\
\hline Clandestinos & $\begin{array}{l}\text { Outorga. } \\
\text { Monitoramento } \\
\text { trimestral de etenos } \\
\text { clorados ou etanos } \\
\text { clorados. Uso da água é } \\
\text { permitido, exceto para } \\
\text { os Usos Preponderantes }\end{array}$ & $\begin{array}{l}\text { Outorga. } \\
\text { Monitoramento } \\
\text { trimestral de etenos } \\
\text { clorados ou etanos } \\
\text { clorados. }\end{array}$ & $\begin{array}{l}\text { Outorga. } \\
\text { Monitoramento } \\
\text { semestral de etenos } \\
\text { clorados ou etanos } \\
\text { clorados. }\end{array}$ \\
\hline Abandonados & Tamponamento & Tamponamento & Tamponamento \\
\hline Poços futuros & Não permitido & Não permitido & Permitido \\
\hline
\end{tabular}

(1) Valores Orientadores de Intervenção (VOI) para a água subterrânea (CETESB, 2005)

(2) Usos Preponderantes: consumo humano, dessedentação de animais, irrigação e recreação (Lei № 9.433/97)

Áreas sem restrição definida seguiriam as regulamentações vigentes, ou seja, um poço clandestino teria que ser outorgado e, um poço abandonado, teria que ser tamponado. Diferencia-se da Área de Baixa Restrição por não ter um monitoramento periódico, a curto prazo, específico para EEC ou EAC e, apenas seguiria as normas de monitoramentos previstas nos processos de regularização de outorga. 
Medidas de controle como a regularização de poços clandestinos e monitoramentos analíticos de água são da maior importância para que os gestores possam priorizar atuações e propiciar o melhor conhecimento da contaminação.

O método permite definir medidas de controle para cada nível de restrição e possibilita readequar os limites das áreas, se houver alteração de cenário provocada por variações das características dessas áreas, caso, por exemplo, um poço de uma área de média ou baixa restrição possa apresentar-se contaminado. Estas variações podem ser decorrentes da perfuração de novos poços e também da evolução do conhecimento com as investigações ou monitoramentos futuros.

Para a apresentação de algumas considerações específicas das medidas de controle para as distintas condições de poços, optou-se por separá-las em três subitens, contendo: área de Alta Restrição; áreas de Média e Baixa restrição; poços clandestinos, poços abandonados e poços futuros; como segue abaixo.

10.2.1 Área de Alta Restrição: monitoramentos periódicos e tamponamento de poços

Para a área de Alta Restrição, caso não haja detecção de EEC ou EAC, ou não se conheça a análise de água do poço, deveria ocorrer um auto-monitoramento em periodicidade trimestral. Este intervalo é sugerido devido ao rápido movimento da água que o bombeamento dos poços provoca, propagando a contaminação. Esses poços poderiam continuar com a exploração e uso da água, exceto para usos preponderantes (consumo humano, dessedentação de animais, irrigação e recreação).

Entende-se por poços que deveriam ser monitorados todos aqueles existentes na área de restrição delimitada independentemente do seu estado de funcionamento, ou seja, que esteja em uso ou não. A confirmação da ocorrência de EEC ou EAC nos poços poderia obedecer a um critério, já praticado pela CETESB, que valida a presença de contaminante com 2 detecções, contínuas ou não, em 3 monitoramentos.

Caso seja detectado EEC ou EAC acima ou abaixo dos VOI, na área de Alta Restrição, seria orientado o tamponamento adequado de poços. Esta medida garante que o poço não venha a ser operado e visa três conseqüências principais:

1) eliminar a via de exposição de um receptor à contaminação;

2) evitar que bombeamentos movimentem a contaminação de maneira não controlada;

3) extinguir a transmissão de contaminação entre diferentes horizontes do aqüífero, ocorrência que foi demonstrada nos ensaios com os obturadores em poços desativados.

Entretanto, para casos em que o interesse em utilizar um poço com EEC ou EAC na área de restrição seja grande, a ponto de estimular a realização de estudos técnicos de detalhe 
que descaracterizem as situações elencadas, estes casos poderiam submeter os projetos à apreciação e ao acompanhamento dos órgãos gestores. Estes projetos teriam o objetivo de comprovar as seguintes situações:

1) a inexistência de receptores da contaminação em níveis de exposição de risco;

2) que o aqüífero, a contaminação e os fluxos decorrentes do bombeamento sejam conhecidos a ponto de serem controlados, sendo que este nível de conhecimento possa demonstrar que os fluxos não espalham a contaminação por áreas não contaminadas.

A proposição de permitir o uso da água sob as condições supracitadas direcionaria para uma solução estratégica que, de um lado, resolveria, com segurança, a necessidade do usuário da água e, de outro lado, contribuiria para o desenvolvimento e a aplicação do conhecimento e das técnicas sobre a hidrogeologia local.

Outra opção para possibilitar a continuação de estudos seria transformar poços de produção com EEC ou EAC em poços de monitoramento com filtros em posições estratégicas, isolando-se os vários níveis do poço. Nesta situação, as solicitações poderiam partir dos órgãos gestores, direcionadas como medidas de compensação a serem tomadas por contaminadores locais, que disponibilizariam os recursos necessários para os projetos.

10.2.2 Áreas de Média e Baixa Restrição: monitoramentos periódicos

Os poços que se encontram nas áreas de Média e Baixa Restrição poderiam ser monitorados em intervalo trimestral ou semestral, respectivamente. Não ocorrendo detecção de EEC ou EAC, esses poços poderiam continuar com a exploração e uso da água. Caso seja detectado e confirmado EEC ou EAC nas análises dos poços, conforme o critério que valida a presença de contaminante com 2 detecções, contínuas ou não, em 3 monitoramentos, a área passaria a ser de Alta Restrição.

10.2.3 Poços clandestinos, poços abandonados e novos poços

Os poços clandestinos, ou seja, que não possuem outorga, teriam que regularizar outorga. No processo de requisição de outorga atentar-se-ia ao cumprimento de medidas de readequação de poços. Independentemente do andamento do processo de regularização de outorga, teriam que ser observadas as medidas de restrições estipuladas para a área em que estivessem situados.

Os poços abandonados, ou seja, aqueles que estão fora de uso, teriam que ser tamponados adequadamente. Estes poços podem ser o canal de conexão de horizontes contaminados do aqüífero com horizontes limpos. 
Novos poços, ou seja, poços a serem perfurados futuramente, seriam permitidos apenas na área de Baixa Restrição. Esta medida tem como finalidade evitar a continuidade da propagação da contaminação e proteger o aqüífero, restringindo o uso. No entanto, esses poços não estariam isentos das medidas de restrição e controle. Teriam que obedecer às medidas de restrição estipuladas para a área em que forem situados. Com isso, ponderar-se-ia sobre o risco de se perfurar um poço novo, uma vez que, caso sejam detectados EEC ou EAC, o poço teria que ser tamponado. Este risco é mais um fator que sustenta que apenas nas áreas de baixa restrição fosse orientada a possibilidade de perfurar novos poços. 


\section{CONCLUSÕES}

A área de estudos, com $120 \mathrm{~km}^{2}$ e uma população de quase 2 milhões de habitantes, apresenta um cenário ambiental bastante crítico, com uma contaminação regional por solventes organoclorados alifáticos que atingiu poços de produção no entorno do canal Jurubatuba, principalmente nas zonas mais densamente industrializadas. A expressão maior deste cenário crítico é evidenciada por alguns importantes números, obtidos com o trabalho, tais como: a existência de uma rede de 513 poços de produção outorgados, acompanhada de uma estimativa de centenas de poços não identificados; a identificação de 2.490 Áreas com Elevado Potencial de Contaminação; a ocorrência de 17 Áreas Declaradas Contaminadas por compostos organoclorados alifáticos e, 46 poços de produção com ocorrência confirmada destes organoclorados, sendo que 28 destes poços apresentaram concentrações acima dos Valores Orientadores de Intervenção.

Para organizar as bases de dados necessárias ao entendimento da quantidade e da qualidade da água utilizada foi montado um consistente cadastro de poços a partir do qual pôde-se trabalhar informações como idade e perfil construtivo do poço, topografia, geologia, parâmetros hidrodinâmicos, finalidade e quantidade de uso da água, entre outros. $O$ cruzamento dessas informações, associadas também às informações de análises químicas da água, foi trabalhado em SIG, multiplicando produtos técnicos ilustrados, por exemplo, o rebaixamento de níveis freáticos em diferentes décadas e a justaposição entre área industrial e área desprovida de coleta de esgoto, o que permitiu a definição de modelos conceituais geológico, hidrogeológico e ambiental, fundamentais para a compreensão do problema e a geração de subsídios técnicos para o traçado da área de restrição de uso da água subterrânea.

O modelo conceitual geológico-estrutural mostrou três meios com diferentes características hidráulicas: o meio sedimentar, na parte superior; a rocha alterada em posição intermediária e a rocha cristalina sã, na base. As seções geológicas permitiram identificar blocos basculados com desníveis verticais de origem tectônica, possivelmente associados a estruturas rúpteis de falhas normais ou inversas. O imageamento acústico mostrou fraturas, que controlam o fluxo da água no aqüífero Cristalino com um predomínio de fraturas de baixo ângulo nas primeiras profundidades e mergulhos intermediários a elevados, com o aumento da profundidade. Um importante aspecto estrutural observado foi a bimodalidade de mergulhos, que deve propiciar melhores condições para a circulação da água, por ter maior quantidade de intersecções de fraturas.

O modelo hidrogeológico conceitual apresenta dois níveis de água, sobretudo próximo ao canal Jurubatuba. O primeiro nível, raso, associado ao aqüífero Sedimentar e concordante com 
os níveis das drenagens locais e o segundo nível, profundo, resultado do intenso bombeamento do aqüífero cristalino, aparentemente deslocado, ou com grande atraso de resposta do aqüífero Sedimentar. É um efeito causado pela anisotropia (vertical versus horizontal) dos aqüíferos Cristalino e Sedimentar. Em contraponto a este modelo de forte anisotropia, observou-se que a rede de poços de produção conecta as partes superiores às inferiores dos aqüíferos, tornado-se uma via significativa no transporte de contaminantes para os diferentes horizontes do aqüífero. Os ensaios com obturadores no aqüífero Cristalino permitiram observar, tanto a ocorrência de fluxos descendentes, quanto de fluxos ascendentes dentro de poços.

O fluxo de água subterrânea no aqüífero Sedimentar possui uma relação direta com as fontes primárias e secundárias de contaminação, enquanto o aqüífero Cristalino tem a potencialidade de propagar a contaminação a distâncias mais longas do que o aqüífero sedimentar, considerando a dinâmica de fluxos por caminhos preferências do aqüífero fraturado e pelo fato deste aqüífero operar sob regimes de bombeamento mais intensos.

Foram observados indicadores de ocorrência de fontes ativas de contaminação, tais como poços de monitoramento com concentrações indicativas da presença de organoclorados em fase livre no aqüífero e o modelo de descarte de efluentes, que sugere, a exemplo de um caso observado, a presença destes organoclorados em galerias ambientalmente irregulares, distribuídas pela área.

Os resultados de análises químicas dos poços de produção mostraram que o TCE ocorre com maior freqüência, seguido pelo PCE, CV e cis-1,2-DCE. Embora o CV ocorra em concentrações relativamente mais baixas, é o que mais ocorre acima dos valores de referência.

Conforme já havia sido apontado pela CETESB, a contaminação provém de múltiplas fontes. A extensão atual conhecida, da área de ocorrência deste conjunto de plumas de contaminação é de aproximadamente $6 \mathrm{~km}$ de cumprimento e $3,5 \mathrm{~km}$ de largura. Entretanto são necessários estudos locais detalhados para melhorar o entendimento sobre as fontes e respectivos limites espaciais destas plumas de contaminação para auxiliar na distribuição de responsabilidades sobre o gerenciamento das áreas contaminadas. Quanto mais estes limites estiverem sobrepostos entre si, maior será a necessidade de gestores públicos e associações industriais definirem, intermediarem e gerenciarem as ações para a recuperação das áreas. A tomada de ações para a recuperação e o controle da contaminação existente deve focar principalmente as zonas rasas do aqüífero, onde o trabalho de recuperação é viável.

Dadas as limitações de técnicas seguras e custos para delimitar os DNAPL em sistemas rochosos fraturados, impossibilitando, em alguns casos a remediação, é importante centralizar esforços na determinação da direção e velocidade de migração da pluma, com especial ênfase 
na coleta de dados para avaliar os riscos potenciais e identificar receptores e permitir que gestores ambientais apliquem medidas para a recuperação ambiental e o gerenciamento do risco à saúde humana. Além de cessar as fontes possíveis e remediar regiões sob ordem de prioridade, em vista da urgência ambiental e da viabilidade de execução, é necessário conhecer todos os poços de produção e importante informar e conscientizar a população sobre a gravidade e o risco potencial do problema.

O histórico do caso, a análise da aplicação da legislação e os estudos relacionados ao tema da dissertação fazem entender que a ação conjunta da CETESB, a COVISA e o DAEE para a lacração dos poços, seguida da criação de uma área de restrição temporária, foi um ponto decisivo e acertado para iniciar o enfrentamento do cenário regional de contaminação do Jurubatuba, tendo em vista que um problema recorrente para a tomada de ações de gerenciamento é a gestão fragmentada entre os órgãos gestores. A experiência internacional tem demonstrado que estas ações de manejo devem estar amparadas pela legislação, o que confere mais um acerto à maneira que estes gestores trabalharam.

Com base nos resultados, propõe-se que a Área de Restrição e Controle seja definida considerando-se a densidade de atividades potenciais de contaminação, áreas contaminadas por organoclorados declaradas e poços de produção com ocorrência de organoclorados. Foram observados, ainda, os instrumentos legais aplicáveis para apontar medidas de restrição. A metodologia caracteriza pequenas áreas, similares em seus níveis de contaminação potenciais e reais, distinguindo-as em três conjuntos, a partir dos quais são traçadas áreas de Alta, Média e Baixa restrição. O método permite definir medidas de controle para cada nível de restrição e possibilita readequar os limites das áreas se houver variações das características dessas áreas. Os parâmetros monitorados teriam que alimentar uma base única, visível aos gestores competentes.

As três áreas com diferentes níveis de restrição e controle da captação e uso das águas subterrâneas estendem-se por $59,75 \mathrm{~km}^{2}$. As áreas de Alta, Média e Baixa Restrição, abrangem áreas totais de $10,75 \mathrm{~km}^{2}, 31 \mathrm{~km}^{2}$ e $18 \mathrm{~km}^{2}$, respectivamente.

A Área de Alta Restrição definida foi significativamente menor do que a "Área de Restrição e Controle Temporário" delimitada inicialmente (com $32 \mathrm{~km}^{2}$ ). O resultado foi diminuir as zonas com proibição de uso de água e, simultaneamente, ampliar o tamanho de áreas de menor nível de restrição implantando controles de regularização de poços e monitoramentos de qualidade da água melhor direcionados e, propiciando, portanto, uma utilização segura do aqüífero. 


\section{REFERÊNCIAS BIBLIOGRÁFICAS}

BERTOLO, R. A. 1996. Relações Entre Rios e o Aqüifero Sedimentar da Bacia de São Paulo em Área de Exploração Intensiva de Água Subterrânea. Dissertação (Mestrado), Instituto de Geociências, Universidade de São Paulo. 108 f.

CAMPOS, J. E. 1988. Indícios de Abatimento dos Níveis de Água Subterrânea da Bacia Sedimentar de São Paulo. In: $5^{\circ}$ CONGRESSO BRASILEIRO DE ÁGUAS SUBTERRÂNEAS. - São Paulo. 5을 Anais...ABAS. p. 74-83.

COSTA FILHO, L. M; VARGAS JÚNIOR, E. 1985. Mechanical and hydraulic properties of tropical residual and lateritic soils. Relatório de Progresso. Associação Internacional de Mecânica dos Solos e Engenharia de Fundações, p. 67 - 84.

COMPANHIA DE TECNOLOGIA DE SANEAMENTO AMBIENTAL (CETESB). 2005. Decisão de Diretoria no 195-2005-E, de 23 de novembro de 2005. Disponível em: shttp://www.cetesb.sp.gov.br/Solo/relatorios/tabela valores 2005.pdf> Acesso em 26/05/2009.

COMPANHIA DE TECNOLOGIA DE SANEAMENTO AMBIENTAL (CETESB). 2009. Histórico. Disponível em: <http://www.cetesb.sp.gov.br/Institucional/historico.asp> Acesso em 26/05/2009.

DEPARTAMENTO DE ÁGUAS E ENERGIA ELÉTRICA (DAEE). 1975. Estudo de águas subterrâneas. Região Administrativa 1 - Grande São Paulo. São Paulo: DAEE, 1975. 3v.

DAEE - DEPARTAMENTO DE ÁGUAS E ENERGIA ELÉTRICA. 2007. Plano Estadual de Recursos Hídricos 2004 / 2007 - Resumo. Disponível em:

http://www.daee.sp.gov.br/acervoepesquisa/perh2204 2207/perh01.pdf Acesso em 12/12/2009.

DAEE - DEPARTAMENTO DE ÁGUAS E ENERGIA ELÉTRICA. 2009. O que é o DAEE. http://www.daee.sp.gov.br/cgi-bin/Carrega.exe?arq=/cgi-bin/montainstitucional.exe/oquee. Acesso em 26/05/2009.

DAEE; IG-SMA; IPT; CPRM. 2005. Mapa de águas subterrâneas do Estado de São Paulo. Org.: ROCHA, G. São Paulo, 119p.

DERBY, O. A. 1898. Ofício 428 de 9/4/1898. Revista Água Subterrânea, 1972. v.1, n.2, 50p.

EMPRESA PAULISTA DE PLANEJAMENTO METROPOLITANO S.A. (EMPLASA). 2005. Mapa de uso e ocupação do solo da Região Metropolitana de São Paulo. 1 CD-ROM. 
ENVIRONMENT AGENCY. 2003. An Illustrated Handbook of DNAPL Transport and Fate in the Subsurface. Bristol, England, 63p.

ECKHARDT D. A. V. ; STACKELBERG, P. E., 1995. Relation of Ground-Water Quality to Land Use on Long Island, New York. Groundwater. v.33, n.6, p.1019-1036.

FEITOSA, F. A. C. ; FILHO, J. M. 1997. Hidrogeologia: Conceitos e Aplicacõos. Fortaleza: CPRM / REFO, LABHID-UFPE. $2^{\underline{a}}$ ed. 389 p.

FOSTER, S. ; HIRATA, R. 1988. Groundwater pollution risk assessment. WHO/PAHO - CEPIS Technical paper. Lima. $81 \mathrm{p}$.

FOSTER, S. ; HIRATA, R. ; GOMES, D. ; D’ELIA, M ; PARIS, M. 2007. Proteção da Qualidade da Água Subterrânea. World Bank e Servmar Serviços Técnicos Ambientais. São Paulo. $104 p$.

FUNDAÇÃO DE APOIO À UNIVERSIDADE DE SÃO PAULO (FUSP). 2002. Plano de Bacia Hidrográfica do Alto Tietê. Caderno Técnico Institucional. São Paulo. Universidade de São Paulo.

FUNDAÇÃO SISTEMA ESTADUAL DE ANÁLISE DE DADOS (SEADE). 2007. Município de São Paulo. http://www.seade.gov.br./produtos/msp/index.php. Acessado em 15/02/2007.

GIANCURSI F. D.; LOPES M. F. C. 1980. Aspectos Hidrológicos da Região Grande São Paulo. Mesa Redonda: Aspectos Geotécnicos da Bacia Sedimentar de São Paulo. Publ. Esp. SBG/ABGE. São Paulo. p. 117 - 128.

GRABER, E. R. ; LAOR, Y.; RONEN, D. 2008. Aquifer contamination by chlorinated-VOCs: the case of an urban metropolis megasite overlying the Coastal Plain aquifer in Israel. Hydrogeology Journal. v. 15, n. 6.

HASUI, Y. ; CREMONINI, O. A. ; BORN, H. . Consideraçõe sobre o Grupo Açungui em São Paulo e porção adjacente do Paraná. In: 33 CONGRESSO BRASILEIRO DE GEOLOGIA, 1984, Rio de Janeiro. Anais. Rio de Janeiro : SBG, 1984. v. 7.

HIRATA, R. C. A.; FERREIRA, L. M. R. 2001. Os aqüíferos da Bacia Hidrográfica do Alto Tietê: disponibilidade hídrica e vulnerabilidade à poluição. Revista Brasileira de Geociências v. 31, n. 1 , p. $43-50$.

HOWARD, K. W. F. 2001. Intensive groundwater use in urban areas: the case of megacities. In: Intensive Use of Groundwater Challenges and Opportunities. Balkema Publishers. The Netherlands. p. $35-57$. 
JULIANI, C. 1992. O embasamento pré-cambriano da Bacia de São Paulo. Seminário: Problemas Geológicos e Geotécnicos na Região Metropolitana de São Paulo (RMSP). ABAS/ ABGE /SBG/ SP, p. 3 - 20.

KRUSEMAN, G.P.; DE RIDDER, N.A. 1991. Analysis and Evaluation of Pumping Test Data. Second Edition, International Institute for Land Reclamation and Improvement, Wageningen, The Netherlands, $377 \mathrm{p}$.

LEVI, F. 1990. Origens, Ambiente e Evolução. In: A Terra Gasta: A Questão do Meio Ambiente. Ed. Educ. Ribeirão Preto, São Paulo, p.17 - 25.

LLAMAS, M.R. ; MARTINEZ, P. 2003. The Silent Revolution of Intensive Groundwater Use: Pros and Cons Groundwater, v. 43, n. 2, 161 p.

LIMA, P. L.; HIRATA, R.; BERTOLO, R; VIVIANI, J. 2004. A interferência antrópica nos padrões naturais de fluxo de água subterrânea: um estudo de caso na Bacia de São Paulo. São Paulo, Brasil. Boletin Geologico y Minero, Madri, v. 115, p. 391 - 398.

MINISTÉRIO DA SAÚDE. 2004. Portaria do Ministério da Saúde ํㅜ 518, de 25 de março de 2004. http://bvsms.saude.gov.br/bvs/publicacoes/portaria_518_2004.pdf. Acesso em 26/05/2009.

PANKOW, J.F. AND CHERRY, J.A.,1996. Dense chlorinated solvents and other DNAPLs in Groundwater. Waterloo Press, p. 522.

PLATT R. H. ; KLEJNA P. B. 2009. Recent Developments in Massachusetts Groundwater Law. Land and Water Policy Center, Department of Geography. University of Massachusetts. Disponível em: <www.ucowr.siu.edu/updates/pdf/V85_A5.pdf>. Acessado em 29/03/2009.

Prefeitura do Município de São Paulo (PMSP). 2002. Atlas Ambiental do Município de São Paulo. Outorgada por Harmi Takiya. Secretaria do Meio Ambiente, Secretaria de Planejamento Urbano.

PREFEITURA DO MUNICÍPIO DE SÃO PAULO (PMSP). 2009. Coordenação de Vigilância em Saúde. Disponível em:

<http://portal.prefeitura.sp.gov.br/secretarias/saude/vigilancia_saude/organizacao/0001> Acesso em 26/05/2009.

REBOUÇAS, A. C. 2002. A Política Nacional de Recursos Hídricos e as Águas Subterrâneas. Revista Águas Subterrâneas. n. 16, p. 95 - 107.

RICCOMINI, C. 1989. O Rift Continental do Sudeste do Brasil. Tese (Doutorado), Instituto de Geociências, Universidade de São Paulo. 256 f. 
RICCOMINI, C.; COIMBRA, A.M.; TAKIYA, H. 1992. Tectônica e sedimentação na Bacia de São Paulo. Seminário: Problemas Geológicos e Geotécnicos na Região Metropolitana de São Paulo (RMSP). ABAS/ ABGE /SBG/ SP, p. 21 - 45.

RICCOMINI, C.; COIMBRA, A.M. 1992. Geologia da Bacia de São Paulo. In: Mesa redonda sobre aspectos geológicos e geotécnicos da Bacia Sedimentar de São Paulo, São Paulo. Anais. São Paulo, ABMS. 59 p.

ROBERTSON GEOLOGING LTD. 2008. Borehole televiewer. Disponível em: $<$ www.geologging.com $>$. Acesso em 07/02/2008.

ROCHA, G. ; GONÇAlVES, V. G. ; REBOUÇAS, A. C. ; BARRETO, L. M. B. 1989. Hidrogeologia da Bacia de São Paulo. Workshop de Geologia da Bacia de São Paulo. IGUSP, SBG/SP. São Paulo. p. 44 - 59.

SALGADO, P. E. T. ; MARONA, H. R. N. 2004. Informações Gerais e Ecotoxicológicas de Solventes Clorados. Série Cadernos de Referência Ambiental, Salvador, v.15, 509 p.

SECRETARIA DO MEIO AMBIENTE DO ESTADO DE SÃO PAULO (SMA). 1997. Mapeamento da vulnerabilidade e risco de poluição das águas subterrâneas do Estado de São Paulo. IG; CETESB; DAEE. Coord: Hirata, R. C. A., Bastos, C. R. A., Rocha, G. A. São Paulo. 2 v.

SERVMAR SERVIÇOS TÉCNICOS AMBIENTAIS LTDA. 2008. Delimitação de Áreas de Restrição e Controle de Captação de Uso de Águas Subterrâneas no Município de São Paulo: Relatório Final. Circulação restrita. 5v.

SERVMAR SERVIÇOS TÉCNICOS AMBIENTAIS LTDA. 2009. Projeto Jurubatuba. Restrição e Controle de Uso de Água Subterrânea. 2009. Inédito. 100p.

SISTEMA INTEGRADO DE GERENCIAMENTO DE RECURSOS HÍDRICOS. 2002. Pluviometria. Disponível em:

$<$ http://www.sigrh.sp.gov.br/cgi-bin/bdhm.exe/procura?dhidro=6\&prefixo=E3 006 > Acesso em 16/07/2007.

SIMS, J. L. ; SUFLITA, J. M. ; RUSSELL, H. H. 1991. Reductive Dehalogenation of Organic Contaminants in Soils and Ground Water.Ground water issue. ADA, O.K., EPA/540/490/054, 12 p.

SOUZA, L. C. 2004. Águas e sua proteção. 1. ed. Curitiba: Juruá, v. 1. 145 p.

SOUZA, L. C. 2006. Estudo de impacto ambiental como instrumento de proteção do meio ambiente. Revista de Direitos Difusos, v. 35, p. 71 - 94. 
TAKYIA, H. 1991. Aplicação de Métodos Quantitativos Espaciais a Dados Geológicos da Bacia de São Paulo. Dissertação (Mestrado), Instituto de Geociências, Universidade de São Paulo. $109 \mathrm{f}$.

HULING, G. S. ; WEAVER, J. W. 1991. Dense nonaqueous phase liquids. Ground water issue. Washington D.C. EPA 540/4-91-002, 21 p.

UNITED STATES ENVIRONMENTAL PROTECTION AGENCY (USEPA). 1998. Technical Protocol for Evaluating Natural Attenuation of Chlorinated Solvents in Ground Water. Ada, Oklahoma. EPA 600/R-98/128. 248 p.

UNITED STATES ENVIRONMENTAL PROTECTION AGENCY (USEPA). 2009. Superfund Sites. Disponível em: <http://www.epa.gov/superfund/sites/>. Acessado em 06/01/2009.

UNITED STATES GEOLOGICAL SERVICES (USGS). 1999. Sustainability of Ground-Water $\underline{\text { Resources. Circular 1186. Denver, Colorado, } 79 \mathrm{p} .}$

UNITED STATES GEOLOGICAL SERVICES (USGS). 2006. Volatile Organic Compounds in the Nation's Ground Water and Drinking-Water Supply Wells. Circular 1292. Reston, Virginia, $101 \mathrm{p}$.

VRBA, J., 2001. The impact of aquifer intensive use on groundwater quality. In: Intensive Use of Groundwater Challenges and Opportunities. Balkema Publishers. The Netherlands. 478 p. 
ANEXO

Cadastro Simplificado de Poços de Produção. 


\begin{tabular}{|c|c|c|c|c|c|c|c|c|c|c|c|c|c|c|c|c|}
\hline \multicolumn{17}{|c|}{ ANEXO - CADASTRO DE POÇOS - Continua } \\
\hline \begin{tabular}{|l} 
No.-de- \\
poços
\end{tabular} & $\begin{array}{l}\text { Poco_ } \\
\text { DAEEE }\end{array}$ & Endereco & Atividade & Cia_Perfuradora & N & E & Cota $(\mathrm{m}) \mid$ & Data_Const & Aquifero & Prof-(m) & \begin{tabular}{|l|} 
Teste- \\
Vazao- \\
(m3/h)
\end{tabular} & \begin{tabular}{|l|} 
TesteN \\
$\mathrm{E}(\mathrm{m})$
\end{tabular} & \begin{tabular}{|l|} 
TesteN \\
$\mathrm{D}(\mathrm{m})$
\end{tabular} & \begin{tabular}{|l|} 
Vazao- \\
Explor- \\
(m3/h)
\end{tabular} & \begin{tabular}{|l} 
ND- \\
explor- \\
(m)
\end{tabular} & \begin{tabular}{|l} 
Horas- \\
Exp
\end{tabular} \\
\hline 1 & 1670 & R. LAURO REINALDO MULLER, 213 & Residencial & $\mathrm{NI}$ & 7377330 & 325860 & 767 & \begin{tabular}{|l|}
$\mathrm{NI}$ \\
\end{tabular} & nao confiavel & 150 & $\mathrm{NI}$ & 40 & $\mathrm{NI}$ & 7,0 & $\mathrm{NI}$ & $\mathrm{NI}$ \\
\hline 2 & 490 & R. TABARE, 551 - GALPAO 5 & Eletro-eletronica & Corner & 7379140 & 328600 & 740 & $08 / 05 / 1972$ & cristalino & 169 & 13,6 & 34 & 72 & 13,0 & 71 & 6 \\
\hline 3 & 491 & R. TABARE, 551 - GALPAO 5 & Eletro-eletronica & Corner & 7379030 & 328470 & 730 & $28 / 02 / 1976$ & cristalino & 221 & 17,0 & 6 & 62 & $\mathrm{NI}$ & $\mathrm{NI}$ & $\mathrm{NI}$ \\
\hline 4 & 1181 & AV. VITOR. MANZINI, 470 & Lavanderias, tinturarias & Corner & 7382060 & 325840 & 724 & jan-80 & nao confiavel & 200 & 2,8 & 25 & 150 & 2,2 & 98 & 20 \\
\hline 5 & 1114 & R. FORTE WILLIAN C/ R. COBALT, S/N & Imobiliaria & Jundsondas & 7385910 & 324580 & 760 & $21 / 06 / 2002$ & nao confiavel & 300 & 0,3 & 38 & 88 & 0,3 & 88 & 18 \\
\hline 6 & 1136 & R. PADRE JOSE DE ANCHIETA, 380/388 & Extracao e comercio de agua & Outras & 7383690 & 326090 & 760 & NI & nao confiavel & 240 & 6,0 & 38 & 118 & 6,0 & 118 & 20 \\
\hline 7 & $\mathrm{NI}$ & R. JOSE DE ANCHIETA, 388 & Extracao e comercio de agua & $\mathrm{NI}$ & 7383660 & 326280 & 760 & $\mathrm{NI}$ & cristalino & 300 & 6,0 & 60 & 190 & 6,0 & 190 & 20 \\
\hline 8 & 1593 & R. DARWIN, 47 & Comercio varejista & Hidrogeo & 7382834 & 326572 & 740 & $24 / 10 / 2003$ & misto 3 & 200 & 15,0 & 25 & 71 & 15,0 & 71 & 10 \\
\hline 9 & 1202 & R. CARVALHO, 01 & \begin{tabular}{|l|} 
Residencial \\
\end{tabular} & Sondamar & 7377190 & 322590 & 758 & $30 / 01 / 2003$ & sedimentar & 150 & 3,6 & 38 & 65 & 3,6 & 65 & 1 \\
\hline 10 & $\mathrm{NI}$ & R. RODRIGUES DE MEDEIROS, 753 & \begin{tabular}{|l|} 
Residencial \\
\end{tabular} & $\mathrm{NI}$ & 7378010 & 330630 & $\mathrm{NI}$ & $08 / 11 / 2001$ & nao confiavel & $\mathrm{NI}$ & $\mathrm{NI}$ & $\mathrm{NI}$ & $\mathrm{NI}$ & $\mathrm{NI}$ & $\mathrm{NI}$ & $\mathrm{NI}$ \\
\hline 11 & $\mathrm{NI}$ & AV. GUARAPIRANGA, 900 & Armazens Gerais & $\mathrm{NI}$ & 7381840 & 324300 & 724 & $27 / 01 / 2000$ & \begin{tabular}{|l|} 
cristalino \\
\end{tabular} & 150 & $\mathrm{NI}$ & $\mathrm{NI}$ & $\mathrm{NI}$ & 4,0 & $\mathrm{NI}$ & 24 \\
\hline 12 & $\mathrm{NI}$ & R. CASSIANO RICARDO , 235 & Residencial & $\mathrm{NI}$ & 7384810 & 328670 & $\mathrm{NI}$ & $25 / 10 / 2000$ & nao confiavel & $\mathrm{NI}$ & $\mathrm{NI}$ & $\mathrm{NI}$ & $\mathrm{NI}$ & $\mathrm{NI}$ & $\mathrm{NI}$ & $\mathrm{NI}$ \\
\hline 13 & 658 & R. MARIA ESTELA, 165 & Clubes e similares & Jundsondas & 7378590 & 322710 & 760 & $0107 / 1999$ & nao confiavel & 211 & 4,2 & 14 & 169 & 4,2 & 169 & 6 \\
\hline 14 & 385 & ESTRADA DE ITAPECERICA, 1.935 & Clubes e similares & NI & 7382980 & 321050 & 745 & NI & nao confiavel & 120 & 3,7 & 10 & 102 & 3,7 & 102 & 20 \\
\hline 15 & 386 & ESTRADA DE ITAPECERICA, 1.935 & Clubes e similares & $\mathrm{NI}$ & 7383250 & 321190 & 750 & $\mathrm{NI}$ & nao confiavel & 120 & 1,3 & 22 & 95 & 1,3 & 95 & 20 \\
\hline 16 & $386 \mathrm{~b}$ & ESTRADA DE ITAPECERICA, 1.935 & Clubes e similares & $\mathrm{NI}$ & 7382960 & 321100 & 750 & jan-94 & $\mathrm{NI}$ & 120 & 2,2 & 3 & 92 & 2,2 & 92 & 20 \\
\hline 17 & $\mathrm{NI}$ & ESTRADA DE ITAPECIRICA 1935 & Clubes e similares & $\mathrm{NI}$ & 7383280 & 321190 & $\mathrm{NI}$ & $06 / 06 / 1998$ & nao confiavel & $\mathrm{NI}$ & $\mathrm{NI}$ & $\mathrm{NI}$ & $\mathrm{NI}$ & $\mathrm{NI}$ & $\mathrm{NI}$ & $\mathrm{NI}$ \\
\hline 18 & 1237 & R. JOAO FRANCISCO DE MOURA, 251 & Hospital & \begin{tabular}{|l|} 
Jundsondas \\
\end{tabular} & 7380000 & 329210 & 785 & $20 / 06 / 2002$ & \begin{tabular}{|l|} 
cristalino \\
\end{tabular} & 300 & 3,0 & 53 & 170 & 3,0 & 170 & 12 \\
\hline 19 & 1238 & R. JOAO FRANCISCO DE MOURA, 251 & Hospital & Jundsondas & 7380110 & 329180 & 790 & $28 / 06 / 2002$ & nao confiavel & 228 & 17,7 & 64 & 139 & 17,7 & 139 & 10 \\
\hline 20 & $\mathrm{NI}$ & R. JOAO FRANCISCO DE MOURA, 252 & Hospital & NI & 7403850 & 324430 & $\mathrm{NI}$ & $\mathrm{NI}$ & $\mathrm{NI}$ & $\mathrm{NI}$ & $\mathrm{NI}$ & $\mathrm{NI}$ & $\mathrm{NI}$ & $\mathrm{NI}$ & $\mathrm{NI}$ & $\mathrm{NI}$ \\
\hline 21 & $\mathrm{NI}$ & R. FLORENVILLE, 280 & Clubes e similares & $\mathrm{NI}$ & 7382100 & 325780 & $\mathrm{NI}$ & $25 / 10 / 2001$ & cristalino & 100 & $\mathrm{NI}$ & $\mathrm{NI}$ & $\mathrm{NI}$ & $\mathrm{NI}$ & $\mathrm{NI}$ & $\mathrm{NI}$ \\
\hline 22 & 1317 & ESTRADA M.BOI MIRIM, 380 & Comercio varejista & Hidrogesp & 7381340 & 323040 & 750 & $17 / 02 / 2002$ & nao confiavel & 100 & 6,0 & 2 & 30 & 6,0 & 30 & 20 \\
\hline 23 & $\mathrm{NI}$ & R. CARLOS LACERDA 30 & \begin{tabular}{|l|} 
Posto de Servicos \\
\end{tabular} & $\mathrm{NI}$ & 7385170 & 318980 & $\mathrm{NI}$ & $25 / 04 / 1998$ & nao confiavel & $\mathrm{NI}$ & $\mathrm{NI}$ & $\mathrm{NI}$ & $\mathrm{NI}$ & $\mathrm{NI}$ & $\mathrm{NI}$ & $\mathrm{NI}$ \\
\hline 24 & 643 & AV. GIOVANNI GRONCHI, 6021 & Posto de Servicos & Tringil & 7385460 & 322890 & 748 & $01 / 02 / 2000$ & nao confiavel & 110 & 1,0 & 62 & 83 & 1,0 & 83 & 20 \\
\hline 25 & 627 & PRACA LISBOA 625 & Posto de Servicos & $\mathrm{NI}$ & 7379750 & 325680 & 747 & $\mathrm{NI}$ & nao confiavel & 10 & $\mathrm{NI}$ & $\mathrm{NI}$ & $\mathrm{NI}$ & 1,1 & $\mathrm{NI}$ & 2 \\
\hline 26 & 725 & AV. DO RIO BONITO, 939 & Posto de Servicos & $\mathrm{NI}$ & 7380050 & 326120 & 742 & $01 / 01 / 1978$ & nao confiavel & 138 & $\mathrm{NI}$ & $\mathrm{NI}$ & $\mathrm{NI}$ & 1,5 & 30 & 10 \\
\hline 27 & 70 & AV. INTERLAGOS, 4300 & Quimica (cosmetico) & T. Janer & 7379770 & 327267 & 726 & $18 / 07 / 1968$ & nao confiavel & 190 & 9,0 & 73 & 119 & $\mathrm{NI}$ & $\mathrm{NI}$ & $\mathrm{NI}$ \\
\hline 28 & 71 & AV. INTERLAGOS, 4300 & Quimica (cosmetico) & T. Janer & 7379610 & 327090 & 726 & $18 / 07 / 1972$ & misto 3 & 126 & 4,8 & 50 & 154 & 10,5 & 154 & 20 \\
\hline 29 & 72 & AV. INTERLAGOS, 4300 & Quimica (cosmetico) & T. Janer & 7379560 & 327120 & 726 & $30 / 09 / 1980$ & cristalino & 145 & 12,0 & 51 & 102 & $\mathrm{NI}$ & $\mathrm{NI}$ & $\mathrm{NI}$ \\
\hline 30 & 266 & AV. INTERLAGOS, 4300 & Quimica (cosmetico) & \begin{tabular}{|l|} 
Falcao Olsen \\
\end{tabular} & 7379870 & 327350 & 726 & $07 / 06 / 1993$ & cristalino & 203 & 21,2 & 65 & 155 & 18,5 & 155 & 20 \\
\hline 31 & 1538 & AV. INTERLAGOS, 4300 & Quimica (cosmetico) & $\mathrm{NI}$ & 7379770 & 327010 & 726 & $25 / 11 / 1999$ & nao confiavel & 315 & 6,0 & 103 & 170 & 3,0 & 170 & 20 \\
\hline 32 & 1539 & AV. INTERLAGOS, 4300 & Quimica (cosmetico) & T. Janer & 7379500 & 327150 & 726 & NI & $\mathrm{NI}$ & $\mathrm{NI}$ & $\mathrm{NI}$ & $\mathrm{NI}$ & $\mathrm{NI}$ & $\mathrm{NI}$ & $\mathrm{NI}$ & $\mathrm{NI}$ \\
\hline 33 & 1540 & AV. INTERLAGOS, 4300 & Quimica (cosmetico) & $\mathrm{NI}$ & 7379430 & 327190 & 726 & $25 / 10 / 1999$ & nao confiavel & 215 & 14,0 & 109 & 154 & 11,0 & 154 & 14 \\
\hline 34 & 204 & R. MANOEL FGGUEREDO LANDIM, 72 & Quimica-Farmaceutica & Geoplan & 7380120 & 327470 & 728 & $18 / 07 / 1995$ & cristalino & 180 & 26,4 & 106 & 124 & 26,0 & 123 & 18 \\
\hline 35 & 325 & R. MANOEL FIGUEIREDO LANDIM, 72 & Quimica-Farmaceutica & Geoplan & 7380160 & 327500 & 729 & $13 / 05 / 1997$ & nao confiavel & 178 & 39,6 & 91 & 130 & 20,0 & 131 & 18 \\
\hline 36 & 774 & AV. ENG. EUSEBIO STEVAUX, 2555 & Quimica-Farmaceutica & $\mathrm{NI}$ & 7380050 & 327600 & 729 & $13 / 12 / 1999$ & misto2 & 208 & 12,1 & 46 & 177 & 10,0 & 177 & 20 \\
\hline 37 & $\mathrm{NI}$ & AV. ENG. EUSEBIO STEVAUX, 2555 & Quimica-Farmaceutica & $\mathrm{NI}$ & 7380030 & 327570 & $\mathrm{NI}$ & $30 / 10 / 1999$ & cristalino & $\mathrm{NI}$ & $\mathrm{NI}$ & $\mathrm{NI}$ & $\mathrm{NI}$ & 15,0 & $\mathrm{NI}$ & $\mathrm{NI}$ \\
\hline 38 & 912 & R. DOMINGOS JORGE, 1100 & Quimica-farmaceutica & Aguabras & 7382580 & 324470 & 723 & $01 / 01 / 1971$ & cristalino & 142 & 40,0 & 7 & 16 & 30,0 & 16 & 8 \\
\hline 39 & 913 & R. DOMINGOS JORGE, 1100 & Quimica-farmaceutica & Outras & 7382330 & 324635 & 723 & $01 / 01 / 1980$ & misto2 & 150 & $\mathrm{NI}$ & 25 & 42 & 26,0 & 42 & 8 \\
\hline 40 & 381 & AV. DE PINEDO, 519 & Hospital & Geoplan & 7381290 & 325180 & 724 & \begin{tabular}{|l|}
$14 / 01 / 1997$ \\
\end{tabular} & nao confiavel & 232 & 15,3 & 14 & 145 & 15,0 & 145 & 18 \\
\hline 41 & 711 & AV. GUIDO CALOI, 1331 & Mecanica & Air Lift & 7382180 & 324030 & 724 & jan-80 & nao confiavel & 250 & 48,0 & 29 & 85 & 48,0 & 85 & 2 \\
\hline 42 & 712 & AV. GUIDO CALOI, 1331 & Mecanica & Air Lift & 7381930 & 323990 & 725 & $01 / 01 / 1975$ & nao confiavel & 183 & 12,0 & 30 & 83 & 12,0 & 83 & 1 \\
\hline 43 & 713 & AV. GUIDO CALOI, 1331 & Mecanica & Air Lift & 7381700 & 324020 & 726 & $01 / 01 / 1975$ & nao confiavel & 250 & 6,0 & $\mathrm{NI}$ & $\mathrm{NI}$ & 6,0 & $\mathrm{NI}$ & 2 \\
\hline 44 & $\mathrm{NI}$ & AV. GUIDO CALOI, 1331 & Mecanica & $\mathrm{NI}$ & 7381800 & 324080 & $\mathrm{NI}$ & NI & $\mathrm{NI}$ & $\mathrm{NI}$ & $\mathrm{NI}$ & $\mathrm{NI}$ & $\mathrm{NI}$ & $\mathrm{NI}$ & $\mathrm{NI}$ & $\mathrm{NI}$ \\
\hline 45 & $\mathrm{NI}$ & R. ENG. MESQUITA SAMPAIO, 782 & Mecanica & $\mathrm{NI}$ & 7386220 & 325900 & $\mathrm{NI}$ & $27 / 07 / 2001$ & nao confiavel & $\mathrm{NI}$ & $\mathrm{NI}$ & $\mathrm{NI}$ & $\mathrm{NI}$ & 1,5 & $\mathrm{NI}$ & 24 \\
\hline
\end{tabular}




\begin{tabular}{|c|c|c|c|c|c|c|c|c|c|c|c|c|c|c|c|c|}
\hline \multicolumn{17}{|c|}{ ANEXO - CADASTRO DE POÇOS - Continuação } \\
\hline \begin{tabular}{|l} 
No.-de- \\
poços
\end{tabular} & $\begin{array}{l}\text { Poco_ } \\
\text { DAEEE }\end{array}$ & Endereco & Atividade & Cia_Perfuradora & $\mathbf{N}$ & E & $\mid \operatorname{cota}(\mathrm{m})$ & Data_Const & Aquifero & Prof-(m) & \begin{tabular}{|l|} 
Teste- \\
Vazao- \\
(m3/h)
\end{tabular} & \begin{tabular}{|l|} 
TesteN \\
$\mathrm{E}(\mathrm{m})$
\end{tabular} & \begin{tabular}{|l|} 
Testen \\
$\mathrm{D}(\mathrm{m})$
\end{tabular} & \begin{tabular}{|l|} 
Vazao- \\
Explor- \\
(m3/h)
\end{tabular} & \begin{tabular}{|l} 
ND- \\
explor- \\
(m)
\end{tabular} & $\begin{array}{l}\text { Horas- } \\
\text { Exp }\end{array}$ \\
\hline 46 & $\mathrm{NI}$ & R. ENG. MESQUITA SAMPAIO, 782 & Mecanica & $\mathrm{NI}$ & 7386250 & 325950 & $\mathrm{NI}$ & $14 / 12 / 1999$ & nao confiavel & $\mathrm{NI}$ & $\mathrm{NI}$ & $\mathrm{NI}$ & $\mathrm{NI}$ & $\mathrm{NI}$ & $\mathrm{NI}$ & $\mathrm{NI}$ \\
\hline 47 & 400 & R. ENG. MESQUITA SAMPAIO,782 & Mecanica & Geoplan & 7386350 & 326270 & 723 & $23 / 01 / 1997$ & cristalino & 255 & 1,9 & 5 & 199 & 1,9 & 199 & 15 \\
\hline 48 & $\mathrm{NI}$ & AV. VEREADOR. JOSE DINIZ, 3465 & Quimica-Farmaceutica & $\mathrm{NI}$ & 7387750 & 329000 & $\mathrm{NI}$ & $21 / 07 / 1995$ & nao confiavel & $\mathrm{NI}$ & $\mathrm{NI}$ & $\mathrm{NI}$ & $\mathrm{NI}$ & 8,0 & $\mathrm{NI}$ & 20 \\
\hline 49 & 126 & AV. VEREADOR. JOSE DINIZ, 3465 & Quimica-Farmaceutica & Corner & 7387070 & 329000 & 750 & & $\mathrm{NI}$ & 88 & 8,0 & $\mathrm{NI}$ & $\mathrm{NI}$ & $\mathrm{NI}$ & $\mathrm{NI}$ & $\mathrm{NI}$ \\
\hline 50 & 1645 & AV. NACOES UNIDAS, 22428 & Quimica-Farmaceutica & $\mid \mathrm{NI}$ & 7380024 & 326888 & 727 & $\mathrm{NI}$ & $\mid \mathrm{NI}$ & $\mathrm{NI}$ & $\mid N I$ & $\mid \mathrm{NI}$ & $\mathrm{NI}$ & $\mathrm{NI}_{\mathrm{NI}}$ & $\mid \mathrm{NI}$ & $\mathrm{NI}$ \\
\hline 51 & 1368 & AV. NACOES UNIDAS, 21344 & Metalurgica & $\mathrm{NI}$ & 7381480 & 326060 & 723 & $\mathrm{NI}$ & $\mathrm{NI}$ & 300 & 20,0 & 120 & 109 & 20,0 & 109 & $\mathrm{NI}$ \\
\hline 52 & 710 & AV. NACOES UNIDAS, 22178 & Posto de Servicos & Hidroway & 7380710 & 326620 & 724 & $01 / 12 / 1999$ & nao confiavel & 220 & 6,0 & 80 & 86 & 3,0 & 83 & 12 \\
\hline 53 & 144 & R. CARLOS GOMES,924 & Quimica-Farmaceutica & Aguabras & 7382820 & 326370 & 740 & $01 / 09 / 1989$ & misto 3 & 254 & 9,6 & 70 & 117 & 9,6 & 117 & 20 \\
\hline 54 & 397 & R. CARLOS GOMES,924 & Quimica-Farmaceutica & Tecnopocos & 7382820 & 326420 & 740 & $01 / 12 / 1981$ & misto3 & 215 & 5,0 & 70 & 117 & 5,0 & 117 & 20 \\
\hline 55 & 398 & R. CARLOS GOMES,924 & Quimica-Farmaceutica & Falcao Olsen & 7382690 & 326520 & 735 & $01 / 11 / 1990$ & cristalino & 230 & 1,5 & 70 & 117 & 1,5 & 117 & 20 \\
\hline 56 & 1303 & R. PROF.CAMPOS DE OLIVEIRA, 252 & Fabricacao de cimento & \begin{tabular}{|l|} 
Hidrogeo \\
\end{tabular} & 7381073 & 326752 & 724 & $09 / 10 / 2002$ & nao confiavel & 226 & 7,2 & 82 & 109 & 7,0 & 109 & 19 \\
\hline 57 & 788 & AV. ALFREDO EGIDIO DE SOUZA ARANHA, 100 & empreendimentos imobiliarios & Hidrogeo & 7385430 & 325400 & 724 & $\mathrm{NI}$ & cristalino & 201 & 6,0 & 11 & 104 & 5,0 & 88 & 12 \\
\hline 58 & 546 & AL. DOS PAMARIS, 50 & alimentacao e bebidas & $\mathrm{NI}$ & 7387830 & 329840 & 752 & $\mathrm{NI}$ & nao confiavel & 12 & $\mathrm{NI}$ & $\mathrm{NI}$ & $\mathrm{NI}$ & $\mathrm{NI}$ & $\mathrm{NI}$ & $\mathrm{NI}$ \\
\hline 59 & 520 & AV. ROQUE PETRONI JUNIOR, 645 & Servicos de automotores & Hidrogesp & 7386230 & 327300 & 725 & $\mathrm{NI}$ & sedimentar & 30 & $\mathrm{NI}$ & 7 & 20 & $\mathrm{NI}$ & 20 & 16 \\
\hline 60 & 1366 & AV. ALBERTO AUGUSANTO ALVES, 50 & Comercio varejista & $\mathrm{NI}$ & 7384280 & 322940 & 740 & $\mathrm{NI}$ & nao confiavel & 220 & 6,0 & 35 & 74 & 7,0 & 74 & $\mathrm{NI}$ \\
\hline 61 & $\mathrm{NI}$ & \begin{tabular}{|l|l} 
ROD. REGIS BITTENCOURT , KM 271,50 \\
\end{tabular} & Comercio varejista & $\mathrm{NI}$ & 7387520 & 318940 & $\mathrm{NI}$ & $30 / 07 / 2003$ & nao confiavel & $\mathrm{NI}$ & $\mathrm{NI}$ & $\mathrm{NI}$ & $\mathrm{NI}$ & 13,0 & $\mathrm{NI}$ & 6 \\
\hline 62 & $\mathrm{NI}$ & R. GEORGE EASTMAN, 213 & Comercio varejista & $\mathrm{NI}$ & 7387360 & 326120 & $\mathrm{NI}$ & $19 / 11 / 2004$ & nao confiavel & $\mathrm{NI}$ & $\mathrm{NI}$ & $\mathrm{NI}$ & $\mathrm{NI}$ & $\mathrm{NI}$ & $\mathrm{NI}$ & $\mathrm{NI}$ \\
\hline 63 & 752 & R. REGINA BADRA, 471 & Servico social & Jundsondas & 7384440 & 327830 & 782 & $26 / 03 / 1998$ & nao confiavel & 162 & 21,7 & 37 & 67 & 9,0 & 44 & 5 \\
\hline 64 & 117 & R. MARFIM, 213 - VILA SABARA & Fabricacao alimentícios & $\begin{array}{ll}\mathrm{NI} \\
\end{array}$ & 7379540 & 329040 & 766 & $24 / 08 / 1982$ & $\mathrm{NI}$ & 170 & 9,0 & $\mathrm{NI}$ & $\mathrm{NI}$ & $\mathrm{NI}$ & $\mathrm{NI}$ & $\mathrm{NI}$ \\
\hline 65 & $\mathrm{NI}$ & R. FREDERICO GUARINON, 125 & empreendimentos imobiliarios & $\mathrm{NI}$ & 7386080 & 323470 & $\mathrm{NI}$ & $17 / 01 / 2001$ & nao confiavel & $\mathrm{NI}$ & $\mathrm{NI}$ & $\mathrm{NI}$ & $\mathrm{NI}$ & $\mathrm{NI}$ & $\mathrm{NI}$ & $\mathrm{NI}$ \\
\hline 66 & $\mathrm{NI}$ & AV. ADOLFO PINHEIRO, 1600 & alimentacao e bebidas & $\mathrm{NI}$ & 7384640 & 326950 & $\mathrm{NI}$ & $13 / 08 / 1999$ & nao confiavel & $\mathrm{NI}$ & $\mathrm{NI}$ & $\mathrm{NI}$ & $\mathrm{NI}$ & $\mathrm{NI}$ & $\mathrm{NI}$ & $\mathrm{NI}$ \\
\hline 67 & $\mathrm{NI}$ & AV. MOREIRA GUIMARAES, 964 & alimentacao e bebidas & $\mathrm{NI}$ & 7387420 & 330800 & $\mathrm{NI}$ & $26 / 09 / 1998$ & nao confiavel & $\mathrm{NI}$ & $\mathrm{NI}$ & $\mathrm{NI}$ & $\mathrm{NI}$ & 1,6 & $\mathrm{NI}$ & 20 \\
\hline 68 & 431 & AV. GUIDO CALOI, 25 & Comercio varejista & Aguabras & 7383760 & 323790 & 730 & $30 / 08 / 1998$ & cristalino & 180 & 36,0 & 35 & 57 & 45,0 & 63 & 10 \\
\hline 69 & 690 & AV. WASHINGYON LUIS, 5859 & \begin{tabular}{|c|} 
Comercio varejista \\
\end{tabular} & $\mathrm{NI}$ & 7385870 & 329890 & 768 & $15 / 10 / 1999$ & sedimentar & 176 & $\mathrm{NI}$ & $\mathrm{NI}$ & $\mathrm{NI}$ & 12,0 & 107 & 18 \\
\hline 70 & 1057 & R. SOCRATES, 120 & Comercio varejista & Geoplan & 7382860 & 327500 & 776 & 07/09/1999 & sedimentar & 114 & 7,2 & 36 & 46 & 3,3 & 41 & 8 \\
\hline 71 & $\mathrm{NI}$ & AV. SANTO AMARO , 4530 & Comercio varejista & $\mathrm{NI}$ & 7386570 & 328080 & $\mathrm{NI}$ & $16 / 07 / 1999$ & nao confiavel & $\mathrm{NI}$ & $\mathrm{NI}$ & $\mathrm{NI}$ & $\mathrm{NI}$ & $\mathrm{NI}$ & $\mathrm{NI}$ & $\mathrm{NI}$ \\
\hline 72 & $\mathrm{NI}$ & AV. SANTO AMARO, 5460 & Comercio varejista & $\mathrm{NI}$ & 7385680 & 327460 & $\mathrm{NI}$ & $07 / 07 / 1999$ & nao confiavel & $\mathrm{NI}$ & $\mathrm{NI}$ & $\mathrm{NI}$ & $\mathrm{NI}$ & $\mathrm{NI}$ & $\mathrm{NI}$ & $\mathrm{NI}$ \\
\hline 73 & $\mathrm{NI}$ & AV. SARGENTO GERALDO SANTANA , 1491 & Comercio varejista & $\mathrm{NI}$ & 7381940 & 328810 & $\mathrm{NI}$ & $07 / 07 / 1999$ & nao confiavel & $\mathrm{NI}$ & $\mathrm{NI}$ & $\mathrm{NI}$ & $\mathrm{NI}$ & $\mathrm{NI}$ & $\mathrm{NI}$ & $\mathrm{NI}$ \\
\hline 74 & 118 & R. ENG. FRANCISCO PITTA BRITO, 138 & Metalurgica & T. Janer & 7383050 & 324800 & 726 & $01 / 03 / 1967$ & nao confiavel & 152 & $\mathrm{NI}$ & $\mathrm{NI}$ & $\mathrm{NI}$ & 8,0 & 100 & 8 \\
\hline 75 & 119 & R. ENG. FRANCISCO PITTA BRITO, 138 & Metalurgica & T. Janer & 7382920 & 324890 & 725 & $01 / 05 / 1976$ & misto 3 & 196 & $\mathrm{NI}$ & $\mathrm{NI}$ & $\mathrm{NI}$ & 3,3 & 112 & 8 \\
\hline 76 & 120 & R. ENG. FRANCISCO PITTA BRITO, 138 & Metalurgica & T. Janer & 7382900 & 324750 & 725 & $\mathrm{NI}$ & nao confiavel & 147 & $\mathrm{NI}$ & 30 & 80 & 6,6 & 80 & 6 \\
\hline 77 & 390 & AV. NACOES UNIDAS, 22452 & Armazens Gerais & Geoplan & 7379980 & 327240 & 724 & $10 / 07 / 1995$ & nao confiavel & 100 & 13,2 & 58 & 78 & 8,0 & 78 & 3 \\
\hline 78 & 513 & AV. NACOES UNIDAS, 18591 & Hoteis e similares & $\mathrm{NI}$ & 7383300 & 324350 & 725 & $\mathrm{NI}$ & nao confiavel & 131 & 3,6 & 12 & 95 & 3,6 & 95 & 4 \\
\hline 79 & 514 & AV. NACOES UNIDAS, 18591 & Hoteis e similares & Hidrogesp & 7383380 & 324450 & 726 & $18 / 08 / 1988$ & cristalino & 190 & 12,0 & 10 & 136 & 12,0 & 136 & 15 \\
\hline 80 & 47 & AV. SANTO AMARO,5137 & Quimica-Farmaceutica & Corner & 7386050 & 327960 & 745 & $29 / 09 / 1973$ & misto 3 & 267 & $\mathrm{NI}$ & 26 & 51 & $\mathrm{NI}$ & $\mathrm{NI}$ & $\mathrm{NI}$ \\
\hline 81 & $\mathrm{NI}$ & R. ITAPAIUNA, $S / \mathrm{N}$ & Imobiliaria & $\mathrm{NI}$ & 7384820 & 323450 & $\mathrm{NI}$ & $26 / 05 / 1998$ & nao confiavel & $\mathrm{NI}$ & $\mathrm{NI}$ & $\mathrm{NI}$ & $\mathrm{NI}$ & 20,0 & $\mathrm{NI}$ & 20 \\
\hline 82 & $\mathrm{NI}$ & R. ITAPAIUNA, $S / N$ & Imobiliaria & $\mathrm{NI}$ & 7385000 & 323510 & $\mathrm{NI}$ & $26 / 05 / 1998$ & nao confiavel & $\mathrm{NI}$ & $\mathrm{NI}$ & $\mathrm{NI}$ & $\mathrm{NI}$ & 20,0 & $\mathrm{NI}$ & 20 \\
\hline 83 & 37 & AV. NACOES UNIDAS, L8001 & Quimica (corantes) & Air Lift & 7383500 & 324400 & 725 & $09 / 05 / 1989$ & misto 2 & 201 & 12,8 & 7 & 75 & $\mathrm{NI}$ & $\mathrm{NI}$ & $\mathrm{NI}$ \\
\hline 84 & 1601 & AV. NACOES UNIDAS, 18001 & Quimica (corantes) & $\mathrm{NI}$ & 7383580 & 324330 & 724 & $\mathrm{NI}$ & $\mathrm{NI}$ & $\mathrm{NI}$ & $\mathrm{NI}$ & $\mathrm{NI}$ & $\mathrm{NI}$ & $\mathrm{NI}$ & $\mathrm{NI}$ & $\mathrm{NI}$ \\
\hline 85 & $\mathrm{NI}$ & $\mathrm{NI}$ & \begin{tabular}{|l} 
Quimica (corantes) \\
\end{tabular} & $\mathrm{NI}$ & 7381290 & 325180 & $\mathrm{NI}$ & $\mathrm{NI}$ & $\mathrm{NI}$ & $\mathrm{NI}$ & $\mathrm{NI}$ & $\mathrm{NI}$ & $\mathrm{NI}$ & $\mathrm{NI}$ & $\mathrm{NI}$ & $\mathrm{NI}$ \\
\hline 86 & 1682 & R. MAESTRADAO JORDAO SENE, 385 & \begin{tabular}{|l|} 
Clinicas geriatricas \\
\end{tabular} & Hidropesquisa & 7384848 & 326149 & 737 & $01 / 04 / 2001$ & cristalino & 105 & $\mathrm{NI}$ & $\frac{\mathrm{NI}}{\mathrm{NI}}$ & $\mathrm{NI}$ & $\mathrm{NI}$ & $\mathrm{NI}$ & $\mathrm{NI}$ \\
\hline 87 & 602 & R. MARECHAL HASTIMPHILO DE MOURA, 641 & alimentacao e bebidas & Geoplan & 7387180 & 322630 & 750 & $31 / 05 / 1999$ & nao confiavel & 54 & 19,2 & 5 & 13 & 5,0 & 13 & 3 \\
\hline 88 & 1618 & AV. FRANCISCO NOBREGA BARBOSA, 411 & Clubes e similares & Aguabras Pocos & 7381052 & 323765 & 759 & $\mathrm{NI}$ & cristalino & 198 & 3,4 & 47 & 131 & 3,0 & 121 & 8 \\
\hline 89 & 1619 & AV. FRANCISCO NOBREGA BARBOSA, 411 & Clubes e similares & Aguabras Pocos & 7380840 & 323550 & 755 & $\mathrm{NI}$ & cristalino & 146 & 3,6 & 48 & 113 & 3,2 & 103 & 8 \\
\hline 90 & $\mid \mathrm{NI}$ & AV. FRANCISCO NOBREGA BARBOSA, 411 & Clubes e similares & $\mathrm{NI}$ & 7381180 & 323760 & $\mathrm{NI}$ & $20 / 12 / 2002$ & nao confiavel & $\mathrm{NI}$ & $\mathrm{NI}$ & $\mathrm{NI}$ & $\mathrm{NI}$ & 5,0 & $\mathrm{NI}$ & 10 \\
\hline
\end{tabular}




\begin{tabular}{|c|c|c|c|c|c|c|c|c|c|c|c|c|c|c|c|c|}
\hline \multicolumn{17}{|c|}{ ANEXO - CADASTRO DE POÇOS - Continuação } \\
\hline \begin{tabular}{|l} 
No.-de- \\
poços
\end{tabular} & $\begin{array}{l}\text { Poco_ } \\
\text { DAEEE }\end{array}$ & Endereco & Atividade & Cia_Perfuradora & N & E & $\mid \operatorname{cota}(\mathrm{m})$ & Data_Const & Aquifero & Prof-(m) & \begin{tabular}{|l|} 
Teste- \\
Vazao- \\
(m3/h)
\end{tabular} & \begin{tabular}{|l|} 
TesteN \\
$\mathrm{E}(\mathrm{m})$
\end{tabular} & \begin{tabular}{|l|} 
TesteN \\
$\mathrm{D}(\mathrm{m})$
\end{tabular} & \begin{tabular}{|l|} 
Vazao- \\
Explor- \\
(m3/h)
\end{tabular} & \begin{tabular}{|l} 
ND- \\
explor- \\
(m)
\end{tabular} & $\begin{array}{l}\text { Horas- } \\
\text { Exp }\end{array}$ \\
\hline 91 & 1660 & R. AMARO ALVES ALVIM, 59 & Residencial & Maxiagua Pocos & 7383230 & 328340 & 785 & $01 / 08 / 2000$ & sedimentar & 85 & 3,0 & 29 & 34 & 3,0 & 34 & 20 \\
\hline 92 & 1234 & R. PALESTINA, 474 & Educacao & Outras & 7384190 & 329630 & 752 & $02 / 04 / 2002$ & sedimentar & 120 & 2,4 & 30 & 38 & 2,4 & 38 & 13 \\
\hline 93 & $\mathrm{NI}$ & AV. JOAO PEDRO CARDOSO, 158 & Educacao & $\mathrm{NI}$ & 7385170 & 330750 & $\mathrm{NI}$ & $15 / 10 / 2002$ & nao confiavel & $\mathrm{NI}$ & $\mathrm{NI}$ & $\mathrm{NI}$ & $\mathrm{NI}$ & 3,0 & $\mathrm{NI}$ & 8 \\
\hline 94 & $\mathrm{NI}$ & R. MICHIGAN, 962 & Educacao & $\mathrm{NI}$ & 7387730 & 327770 & $\mathrm{NI}$ & $07 / 05 / 2004$ & nao confiavel & $\mathrm{NI}$ & $\mathrm{NI}$ & $\mathrm{NI}$ & $\mathrm{NI}$ & 3,0 & $\mathrm{NI}$ & 5 \\
\hline 95 & 1172 & R. BARAO DO TRIUNFO, 1052 & Educacao & $\mathrm{NI}$ & 7386860 & 328740 & 745 & $\mathrm{NI}$ & sedimentar & 10 & 0,5 & 3 & 3 & 0,5 & 3 & 3 \\
\hline 96 & $\mathrm{NI}$ & R. RAPHAEL DE MARCO 45 & Madeira & $\mathrm{NI}$ & 7386510 & 318880 & $\mathrm{NI}$ & $28 / 05 / 2002$ & nao confiavel & $\mathrm{NI}$ & $\mathrm{NI}$ & $\mathrm{NI}$ & $\mathrm{NI}$ & 12,0 & $\mathrm{NI}$ & 1 \\
\hline 97 & 1359 & R. KARL RICHTER, 80 & Residencial & Jundsondas & 7386980 & 322360 & 790 & $08 / 11 / 2001$ & nao confiavel & 169 & 18,0 & 34 & 47 & 18,0 & 47 & 2 \\
\hline 98 & 195 & AV. MARG DO RIO PINHEIROS, 5200 & Escritorios & General Water S/A & 7386720 & 326200 & 728 & $05 / 01 / 2003$ & cristalino & 276 & 3,2 & 9 & 155 & 3,0 & 151 & 17 \\
\hline 99 & 1196 & AV. MARG DO RIO PINHEIROS, 5200 & Escritorios & General Water S/A & 7386800 & 326340 & 725 & $05 / 01 / 2003$ & cristalino & 180 & 3,6 & 13 & 128 & 3,6 & 128 & 17 \\
\hline 100 & $\mathrm{NI}$ & AV. MARG DO RIO PINHEIROS, 5201 & Escritorios & General Water S/A & 738677 & 32621 & $\mathrm{NI}$ & $01 / 02 / 2007$ & cristalino & 342 & $\mathrm{NI}$ & $\mathrm{NI}$ & $\mathrm{NI}$ & $\mathrm{NI}$ & $\mathrm{NI}$ & $\mathrm{NI}$ \\
\hline 101 & 1683 & R. BORBA GATO, 59 & Shopping & SOS pocos artesianos & 7383020 & 326550 & 750 & $04 / 06 / 2004$ & cristalino & 150 & 6,5 & 50 & 92 & 6,5 & 92 & 20 \\
\hline 102 & 1360 & AV. NACOES UNIDAS 12901 & Residencial & \begin{tabular}{|l|l} 
Hidromac \\
\end{tabular} & 7387960 & 326850 & 727 & $10 / 11 / 2002$ & nao confiavel & 303 & 8,0 & 35 & 108 & 8,0 & 108 & 20 \\
\hline 103 & 1361 & AV. NACOES UNIDAS, 12901 & Residencial & Hidromac & 7387800 & 326930 & 725 & $10 / 11 / 2002$ & nao confiavel & 306 & 3,6 & 41 & 146 & 3,6 & 146 & 20 \\
\hline 104 & $\mathrm{NI}$ & AV. NACOES UNIDAS, 12901 & Residencial & $\mathrm{NI}$ & 7387680 & 326790 & $\mathrm{NI}$ & $14 / 09 / 2002$ & nao confiavel & $\mathrm{NI}$ & $\mathrm{NI}$ & $\mathrm{NI}$ & $\mathrm{NI}$ & $\mathrm{NI}$ & $\mathrm{NI}$ & $\mathrm{NI}$ \\
\hline 105 & 162 & AV. MARIA COELHO AGUIAR, 215 & Comercial & T. Janer & 7383400 & 323670 & 769 & $12 / 11 / 1974$ & misto 2 & 180 & 7,2 & 62 & 91 & $\mathrm{NI}$ & $\mathrm{NI}$ & $\mathrm{NI}$ \\
\hline 106 & 163 & AV. MARIA COELHO AGUIAR, 215 & Comercial & T. Janer & 7383420 & 323620 & 769 & $27 / 05 / 1975$ & misto 2 & 180 & 8,0 & 61 & 112 & $\mathrm{NI}$ & $\mathrm{NI}$ & $\mathrm{NI}$ \\
\hline 107 & 164 & AV. MARIA COELHO AGUIAR, 215 & Comercial & T. Janer & 7383520 & 323670 & 769 & $27 / 05 / 1975$ & cristalino & 180 & 8,0 & 56 & 98 & $\mathrm{NI}$ & $\mathrm{NI}$ & $\mathrm{NI}$ \\
\hline 108 & 165 & AV. MARIA COELHO AGUIAR, 215 & Comercial & T. Janer & 7383700 & 323620 & 769 & $10 / 06 / 1975$ & cristalino & 179 & 6,0 & 36 & 98 & $\mathrm{NI}$ & $\mathrm{NI}$ & $\mathrm{NI}$ \\
\hline 109 & 561 & R. CAMBUCI DO VALE, 597 & Residencial & \begin{tabular}{|l|} 
Jundsondas \\
\end{tabular} & 7376350 & 326170 & 750 & $15 / 01 / 1999$ & nao confiavel & 522 & 0,5 & 8 & 171 & 0,5 & 171 & 20 \\
\hline 110 & 299 & R. VICENTE PEREIRA DE ASSUNCAO, 55 & Residencial & \begin{tabular}{|l|} 
Hidrogeo \\
\end{tabular} & 7381670 & 329450 & 775 & $01 / 01 / 1996$ & misto2 & 190 & 15,0 & 35 & 81 & 15,0 & $\mathrm{NI}$ & 20 \\
\hline 111 & 1431 & AV. INTERLAGOS, 871 & Residencial & Hidrogeo & 7382170 & 328950 & 759 & $10 / 07 / 2000$ & cristalino & 258 & 1,5 & 3 & 176 & 1,5 & 176 & 20 \\
\hline 112 & $\mathrm{NI}$ & AV. INTERLAGOS, 871 & Residencial & $\mathrm{NI}$ & 7382210 & 329000 & 759 & & cristalino & 150 & 3,0 & 70 & $\mathrm{NI}$ & $\mathrm{NI}$ & $\mathrm{NI}$ & $\mathrm{NI}$ \\
\hline 113 & $\mathrm{NI}$ & ESTRADA DO CAMPO LIMPO , 291 & Residencial & $\mathrm{NI}$ & 7383550 & 320880 & $\mathrm{NI}$ & $19 / 04 / 2002$ & nao confiavel & $\mathrm{NI}$ & $\mathrm{NI}$ & $\mathrm{NI}$ & $\mathrm{NI}$ & $\mathrm{NI}$ & $\mathrm{NI}$ & $\mathrm{NI}$ \\
\hline 114 & 982 & R. CONSANTANTINO DE SOUZA, 1070 & Imobiliaria & Hidroway & 7386790 & 329010 & 755 & $\mathrm{NI}$ & sedimentar & 123 & 4,0 & 20 & 82 & 4,0 & 82 & 8 \\
\hline 115 & $\mathrm{NI}$ & R. COND. ED'EU, 1000 & Residencial & $\mathrm{NI}$ & 7384340 & 327420 & $\mathrm{NI}$ & $27 / 09 / 2000$ & nao confiavel & $\mathrm{NI}$ & $\mathrm{NI}$ & $\mathrm{NI}$ & $\mathrm{NI}$ & $\mathrm{NI}$ & $\mathrm{NI}$ & $\mathrm{NI}$ \\
\hline 116 & 1929 & R. JOAQUIM JOSE ESTEVES, 60 & Residencial & $\mathrm{NI}$ & 7383510 & 327310 & $\mathrm{NI}$ & $\mathrm{NI}$ & $\mathrm{NI}$ & $\mathrm{NI}$ & $\mathrm{NI}$ & $\mathrm{NI}$ & $\mathrm{NI}$ & $\mathrm{NI}$ & $\mathrm{NI}$ & $\mathrm{NI}$ \\
\hline 117 & 1930 & R. JOAQUIM JOSE ESTEVES, 60 & \begin{tabular}{|l|} 
Residencial \\
\end{tabular} & $\mathrm{NI}$ & 7383540 & 327350 & $\mathrm{NI}$ & $\mathrm{NI}$ & NI & $\mathrm{NI}$ & $\mathrm{NI}$ & $\mathrm{NI}$ & $\mathrm{NI}$ & $\mathrm{NI}$ & $\mathrm{NI}$ & $\mathrm{NI}$ \\
\hline 118 & 1365 & R. ITAJARA, 299 & Imobiliaria & Silva Estacas & 7385500 & 323350 & 775 & $23 / 03 / 2004$ & nao confiavel & 195 & 6,0 & 31 & 134 & 6,0 & 134 & 20 \\
\hline 119 & 1332 & R. DAVID BEN GURION, 11064 & Residencial & Hidroway & 7387950 & 323000 & 795 & NI & nao confiavel & 200 & 4,2 & 79 & 151 & 6,0 & 95 & 20 \\
\hline 120 & 87 & AV. ROQUE PETRONI, 1089 & Shopping & Aguabras & 7386240 & 326740 & 723 & $17 / 11 / 1992$ & $\mathrm{NI}$ & 0 & $\mathrm{NI}$ & $\mathrm{NI}$ & $\mathrm{NI}$ & $\mathrm{NI}$ & $\mathrm{NI}$ & $\mathrm{NI}$ \\
\hline 121 & 621 & AV. ROQUE PETRONI JR., 1089 & Shopping & NI & 7386270 & 326700 & 724 & $\mathrm{NI}$ & cristalino & 172 & 4,2 & 48 & 63 & 1,8 & 62 & 16 \\
\hline 122 & 622 & AV. ROQUE PETRONI JR., 1089 & Shopping & Geoplan & 7386300 & 326750 & 723 & $13 / 06 / 1998$ & nao confiavel & 300 & 3,0 & 42 & 143 & 2,3 & 143 & 16 \\
\hline 123 & 623 & AV. ROQUE PETRONI JR. ,1089 & Shopping & Geoplan & 7386390 & 326670 & 723 & 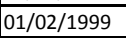 & cristalino & 258 & 4,2 & 50 & 119 & 3,9 & 119 & 16 \\
\hline 124 & $\mathrm{NI}$ & AV. ROQUE PETRONI JR., 1089 & Shopping & $\mathrm{NI}$ & 7386440 & 326690 & $\mathrm{NI}$ & \begin{tabular}{|l|l|l|l|l|l|}
$\mathrm{NI}$ \\
\end{tabular} & nao confiavel & $\mathrm{NI}$ & $\mathrm{NI}$ & $\mathrm{NI}$ & $\mathrm{NI}$ & $\mathrm{NI}$ & $\mathrm{NI}$ & $\mathrm{NI}$ \\
\hline 125 & $\mathrm{NI}$ & R. ALEXANDRE DUMAS, 1711 & Residencial & $\mathrm{NI}$ & 7385590 & 325810 & $\mathrm{NI}$ & $\mathrm{NI}$ & nao confiavel & $\mathrm{NI}$ & $\mathrm{NI}$ & $\mathrm{NI}$ & $\mathrm{NI}$ & $\mathrm{NI}$ & $\mathrm{NI}$ & $\mathrm{NI}$ \\
\hline 126 & $\mathrm{NI}$ & R. PROF JOSE HORACIO TEIXEIRA, 538 & Residencial & $\mathrm{NI}$ & 7387730 & 323030 & $\mathrm{NI}$ & $\mathrm{NI}$ & nao confiavel & $\mathrm{NI}$ & $\mathrm{NI}$ & $\mathrm{NI}$ & $\mathrm{NI}$ & $\mathrm{NI}$ & $\mathrm{NI}$ & $\mathrm{NI}$ \\
\hline 127 & 1512 & R. ALEXANDRE DUMAS, 2200 & Residencial & General Water & 7386000 & 325500 & 722 & $13 / 05 / 2004$ & cristalino & 300 & 1,2 & 9 & 140 & 1,2 & 140 & 20 \\
\hline 128 & $\mathrm{NI}$ & R. ITAPIMIRUM, 690 & Residencial & $\mathrm{NI}$ & 7385580 & 323150 & $\mathrm{NI}$ & NI & nao confiavel & $\mathrm{NI}$ & $\mathrm{NI}$ & $\mathrm{NI}$ & $\mathrm{NI}$ & $\mathrm{NI}$ & $\mathrm{NI}$ & $\mathrm{NI}$ \\
\hline 129 & $\mathrm{NI}$ & AV. VERBO DIVINO, 1400 & Residencial & $\mathrm{NI}$ & 7385580 & 325660 & $\mathrm{NI}$ & $\mathrm{NI}$ & nao confiavel & $\mathrm{NI}$ & $\mathrm{NI}$ & $\mathrm{NI}$ & $\mathrm{NI}$ & $\mathrm{NI}$ & $\mathrm{NI}$ & $\mathrm{NI}$ \\
\hline 130 & $\mathrm{NI}$ & AV. NACOES UNIDAS, 17891 & Residencial & $\mathrm{NI}$ & 7383930 & 324080 & $\mathrm{NI}$ & $13 / 07 / 2002$ & nao confiavel & $\mathrm{NI}$ & $\mathrm{NI}$ & $\mathrm{NI}$ & $\mathrm{NI}$ & $\mathrm{NI}$ & $\mathrm{NI}$ & $\mathrm{NI}$ \\
\hline 131 & 1079 & AV. SANTO AMARO, 7194 & Residencial & Sondagua & 7384340 & 326610 & 763 & $12 / 02 / 2001$ & cristalino & 183 & 4,2 & 44 & 152 & 4,0 & 152 & 18 \\
\hline 132 & 687 & AV. ADOLFO PINHEIRO, 1000 & Residencial & Jundsondas & 7384090 & 326640 & 763 & $10 / 10 / 1997$ & nao confiavel & 220 & 14,4 & 100 & 102 & 18,0 & 103 & 3 \\
\hline 133 & 987 & R. PROF.DJALMA BANTO, 206 & Residencial & ABC Pocos & 7381765 & 328565 & 770 & \begin{tabular}{|l|}
$01 / 04 / 1991$ \\
\end{tabular} & sedimentar & 60 & 0,8 & 23 & 41 & 0,8 & 41 & 16 \\
\hline 134 & 1400 & R. DEMOSTENES, 636 & Residencial & Saiagua & 7387330 & 329350 & 747 & $08 / 05 / 2004$ & nao confiavel & 107 & 8,0 & 44 & 46 & 8,0 & 46 & 6 \\
\hline 135 & 1307 & AV. ROQUE PETRONI JR. , 1000 & Residencial & Outras & 7386470 & 327010 & 726 & 04/05/2004 & misto1 & 270 & 0,6 & 53 & 204 & 0,6 & 204 & 18 \\
\hline
\end{tabular}




\begin{tabular}{|c|c|c|c|c|c|c|c|c|c|c|c|c|c|c|c|c|}
\hline \multicolumn{17}{|c|}{ ANEXO - CADASTRO DE POÇOS - Continuação } \\
\hline \begin{tabular}{|l} 
No.-de- \\
poços
\end{tabular} & $\begin{array}{l}\text { Poco_ } \\
\text { DAEEE }\end{array}$ & Endereco & Atividade & Cia_Perfuradora & N & E & $\mid \operatorname{cota}(\mathrm{m})$ & Data_Const & Aquifero & Prof-(m) & \begin{tabular}{|l|} 
Teste- \\
Vazao- \\
(m3/h)
\end{tabular} & \begin{tabular}{|l|} 
TesteN \\
$\mathrm{E}(\mathrm{m})$
\end{tabular} & \begin{tabular}{|l|} 
TesteN \\
$\mathrm{D}(\mathrm{m})$
\end{tabular} & \begin{tabular}{|l|} 
Vazao- \\
Explor- \\
(m3/h)
\end{tabular} & \begin{tabular}{|l} 
ND- \\
explor- \\
(m)
\end{tabular} & $\begin{array}{l}\text { Horas- } \\
\text { Exp }\end{array}$ \\
\hline 136 & $\mathrm{NI}$ & R. FREDERICO GUARINON, 935 & Residencial & $\mathrm{NI}$ & 7386090 & 323430 & $\mathrm{NI}$ & $12 / 02 / 1998$ & nao confiavel & $\mathrm{NI}$ & $\mathrm{NI}$ & $\mathrm{NI}$ & $\mathrm{NI}$ & 6,7 & $\mathrm{NI}$ & 20 \\
\hline 137 & 1141 & R. CONSTANTINO DE SOUZA, 454 & Residencial & Hidroway & 7387240 & 329330 & 747 & $\mathrm{NI}$ & sedimentar & 120 & 7,0 & 20 & 82 & 7,0 & 82 & 8 \\
\hline 138 & 654 & R. DO ANGULO, 412 & Residencial & Hidrogeo & 7385900 & 323530 & 772 & $17 / 11 / 1999$ & nao confiavel & 180 & 5,4 & 26 & 66 & 4,0 & 56 & 10 \\
\hline 139 & 1297 & R. CONCEICAO DE MONTE ALEGRE, 351 & Residencial & Hidrogesp & 7387810 & 327380 & 725 & $\mathrm{NI}$ & nao confiavel & 250 & 2,4 & 81 & 164 & 2,4 & 164 & 20 \\
\hline 140 & 1430 & R. CARLOS QUEIROZ TELLES, 162 & Residencial & Hidroklockner & 7385810 & 324260 & 792 & $29 / 09 / 2004$ & cristalino & 222 & 5,5 & 54 & 141 & 5,0 & 132 & 15 \\
\hline 141 & 1108 & R. FERNANDES MOREIRA, 1293 & Residencial & Outras & 7385720 & 325920 & 726 & NI & cristalino & 154 & 1,0 & 19 & 118 & 1,0 & 118 & 20 \\
\hline 142 & 652 & R. DR. OSCAR. MONTEIRO DE BARRO, 333 & Residencial & \begin{tabular}{|l|} 
Jundsondas \\
\end{tabular} & 7387140 & 323200 & 805 & $29 / 07 / 1999$ & nao confiavel & 200 & 14,0 & 11 & 58 & 14,0 & 58 & 20 \\
\hline 143 & $\mathrm{NI}$ & R. PASCAL, 437 & Residencial & $\mathrm{NI}$ & 7387220 & 328960 & $\mathrm{NI}$ & $01 / 02 / 2005$ & nao confiavel & $\mathrm{NI}$ & $\mathrm{NI}$ & $\mathrm{NI}$ & $\mathrm{NI}$ & 4,2 & $\mathrm{NI}$ & 7 \\
\hline 144 & 1386 & R. PROF.ALEXANDRE CORREA, 481 & Residencial & \begin{tabular}{|l|} 
Jundsondas \\
\end{tabular} & 7386640 & 324459 & 787 & $21 / 07 / 2000$ & cristalino & 320 & 1,3 & 75 & 222 & 1,3 & 222 & 20 \\
\hline 145 & 222 & R. JOSE GALANTE,811 & Residencial & Aguabras & 7386590 & 322640 & 815 & $31 / 10 / 1989$ & cristalino & 185 & 5,0 & 38 & 155 & 5,0 & $\mathrm{NI}$ & 20 \\
\hline 146 & 856 & R. JOAO DE SOUZA DIAS, 881 & $\begin{array}{l}\text { Residencial } \\
\end{array}$ & \begin{tabular}{|l|} 
Aguasonda \\
\end{tabular} & 7386780 & 329050 & 755 & $12 / 08 / 2001$ & sedimentar & 90 & 3,0 & 18 & 49 & 2,0 & 31 & 20 \\
\hline 147 & 773 & R. ALMADEN,49 & $\begin{array}{l}\text { Residencial } \\
\end{array}$ & \begin{tabular}{|l} 
Jundsondas \\
\end{tabular} & 7384980 & 323030 & 770 & $25 / 08 / 2000$ & nao confiavel & 282 & 2,0 & 53 & 134 & 2,0 & 134 & 12 \\
\hline 148 & 1236 & R. NELSON GAMA DE OLIVEIRA, 143 & Residencial & Garca Pocos & 7385240 & 323120 & 770 & $12 / 05 / 2003$ & nao confiavel & 250 & 6,0 & 20 & 84 & 6,0 & 84 & 20 \\
\hline 149 & 993 & R. ITAAARA, 245 & Residencial & Jundsondas & 7385360 & 323390 & 755 & $01 / 11 / 2001$ & nao confiavel & 300 & 5,5 & 17 & 154 & 5,5 & 154 & 7 \\
\hline 150 & 1191 & R. SILVINO CANUTO ABREU, 153 & Residencial & Aguasonda & 7385830 & 329720 & 764 & $10 / 03 / 2003$ & sedimentar & 98 & 4,3 & 33 & 39 & 2,0 & 39 & 12 \\
\hline 151 & 903 & R. DEP.JOAO SUSSUMU HIRATA, 365 & Residencial & \begin{tabular}{|l|} 
Hidroarte \\
\end{tabular} & 7385700 & 323450 & 745 & $22 / 05 / 2001$ & \begin{tabular}{|l|} 
cristalino \\
\end{tabular} & 222 & 8,3 & 11 & 22 & 8,0 & 22 & 9 \\
\hline 152 & $\mathrm{NI}$ & AV. DOS AICAS, 927 & Residencial & $\mathrm{NI}$ & 7387830 & 330660 & $\mathrm{NI}$ & $11 / 08 / 2004$ & nao confiavel & $\mathrm{NI}$ & $\mathrm{NI}$ & $\mathrm{NI}$ & $\mathrm{NI}$ & 2,5 & $\mathrm{NI}$ & 20 \\
\hline 153 & $\mathrm{NI}$ & R. REPUBLICA DO IRAQUE, 1406 & Residencial & $\mathrm{NI}$ & 7386510 & 329690 & $\mathrm{NI}$ & NI & nao confiavel & $\mathrm{NI}$ & $\mathrm{NI}$ & $\mathrm{NI}$ & $\mathrm{NI}$ & 2,0 & $\mathrm{NI}$ & 10 \\
\hline 154 & $\mathrm{NI}$ & R. PRINCESA ISABEL, 826 & Residencial & $\mathrm{NI}$ & 7386960 & 328560 & $\mathrm{NI}$ & $\mathrm{NI}$ & nao confiavel & $\mathrm{NI}$ & $\mathrm{NI}$ & $\mathrm{NI}$ & $\mathrm{NI}$ & 2,4 & $\mathrm{NI}$ & 12 \\
\hline 155 & 996 & R. COND.E DE PORTO ALEGRE, 1270 & Residencial & Aguasonda & 7386630 & 329350 & 755 & $19 / 02 / 2002$ & sedimentar & 112 & 4,2 & 23 & 28 & 2,0 & 28 & 18 \\
\hline 156 & 781 & R. JOAO DE SOUZA DIAS,719 & Residencial & Aguasonda & 7386690 & 329180 & 756 & $17 / 03 / 2001$ & sedimentar & 94 & 4,0 & 24 & 30 & 2,0 & 30 & 18 \\
\hline 157 & 1121 & R. VOLTA REDONDA, 707 & Residencial & Aguasonda & 7386050 & 329450 & 770 & $10 / 10 / 2002$ & sedimentar & 102 & 4,8 & 31 & 37 & 2,0 & 37 & 18 \\
\hline 158 & 1192 & \begin{tabular}{|l|} 
R. VOLTA REDONDA, 744 \\
\end{tabular} & Residencial & Aguasonda & 7386000 & 329470 & 765 & $20 / 03 / 2003$ & sedimentar & 110 & 4,8 & 28 & 33 & 2,0 & 33 & 18 \\
\hline 159 & 970 & R. JOAO DE SOUZA DIAS, 520 & Residencial & \begin{tabular}{|l|} 
Aguasonda \\
\end{tabular} & 7386580 & 329340 & 757 & $17 / 10 / 2001$ & sedimentar & 106 & 3,7 & 26 & 28 & 2,0 & 28 & 20 \\
\hline 160 & 1035 & R. PRINCESA ISABEL, 414 & Residencial & Garca Pocos & 7386650 & 328400 & 736 & $04 / 01 / 2002$ & nao confiavel & 230 & 5,0 & 72 & 166 & 5,0 & 166 & 8 \\
\hline 161 & 1215 & AV. DR. SILVA MELO, 520 & Residencial & $\mathrm{NI}$ & 7382285 & 328205 & 750 & $20 / 06 / 1905$ & nao confiavel & 15 & $\mathrm{NI}$ & $\mathrm{NI}$ & $\mathrm{NI}$ & 2,2 & 10 & 2 \\
\hline 162 & $\mathrm{NI}$ & AV. PORTUGAL, 277 & \begin{tabular}{|l|} 
Residencial \\
\end{tabular} & $\mathrm{NI}$ & 7387070 & 328140 & $\mathrm{NI}$ & $18 / 09 / 2001$ & nao confiavel & $\mathrm{NI}$ & $\mathrm{NI}$ & $\mathrm{NI}$ & $\mathrm{NI}$ & $\mathrm{NI}$ & $\mathrm{NI}$ & $\mathrm{NI}$ \\
\hline 163 & 374 & R. VIEIRA DE MORAIS, 601 & Residencial & $\mathrm{NI}$ & 7386920 & 329170 & 750 & $\mathrm{NI}$ & sedimentar & 102 & 6,5 & 16 & 42 & 6,5 & 42 & 20 \\
\hline 164 & $\mathrm{NI}$ & R. DEP. JOAO SUSSUMU HIRATA,38 & Residencial & $\mathrm{NI}$ & 7386090 & 323200 & $\mathrm{NI}$ & $13 / 09 / 2000$ & nao confiavel & $\mathrm{NI}$ & $\mathrm{NI}$ & $\mathrm{NI}$ & $\mathrm{NI}$ & $\mathrm{NI}$ & $\mathrm{NI}$ & $\mathrm{NI}$ \\
\hline 165 & 959 & R. BARAO DO JACEGUAl, 1046 & Residencial & Aguasonda & 7386680 & 329070 & 756 & $13 / 12 / 2001$ & sedimentar & 116 & 3,6 & 16 & 36 & 1,5 & $\mathrm{NI}$ & 20 \\
\hline 166 & $\mathrm{NI}$ & AV. JOSE GALANTE, 589 & Residencial & $\mathrm{NI}$ & 7386650 & 322820 & $\mathrm{NI}$ & $\mathrm{NI}$ & nao confiavel & $\mathrm{NI}$ & $\mathrm{NI}$ & $\mathrm{NI}$ & $\mathrm{NI}$ & 5,0 & $\mathrm{NI}$ & 20 \\
\hline 167 & 898 & R. BARAO DO JACEGUAI, 1195 & Residencial & Aguasonda & 7386830 & 329150 & 755 & $22 / 08 / 2001$ & sedimentar & 90 & 4,0 & 22 & 27 & 1,5 & 27 & 20 \\
\hline 168 & 730 & R. DR. JOSE A.FIGUEIRA, 170 & Residencial & Garca Pocos & 7386960 & 322280 & 783 & $10 / 06 / 2000$ & cristalino & 180 & 18,0 & 24 & 101 & 18,0 & 101 & 3 \\
\hline 169 & $\mathrm{NI}$ & R. DR. LUIZ MIGLIANO, 871 & $\begin{array}{l}\text { Residencial } \\
\end{array}$ & $\mathrm{NI}$ & 7387600 & 322000 & $\mathrm{NI}$ & $\mathrm{NI}$ & nao confiavel & $\mathrm{NI}$ & $\mathrm{NI}$ & $\mathrm{NI}$ & $\mathrm{NI}$ & $\mathrm{NI}$ & $\mathrm{NI}$ & $\mathrm{NI}$ \\
\hline 170 & 1104 & AV. JURUBATUBA, 73 & Residencial & Silva Estacas & 7387020 & 326950 & 724 & $18 / 03 / 2002$ & cristalino & 200 & 4,5 & 21 & 47 & 4,5 & 47 & 15 \\
\hline 171 & $\mathrm{NI}$ & AV. JURUBATUBA, 73 & Residencial & $\mathrm{NI}$ & 7387020 & 326950 & $\mathrm{NI}$ & NI & nao confiavel & $\mathrm{NI}$ & $\mathrm{NI}$ & $\mathrm{NI}$ & $\mathrm{NI}$ & 4,5 & $\mathrm{NI}$ & 15 \\
\hline 172 & $\mathrm{NI}$ & R. ABDO AMBUDA, 239 & Residencial & $\mathrm{NI}$ & 7386300 & 323000 & $\mathrm{NI}$ & $\mathrm{NI}$ & nao confiavel & $\mathrm{NI}$ & $\mathrm{NI}$ & $\mathrm{NI}$ & $\mathrm{NI}$ & $\mathrm{NI}$ & $\mathrm{NI}$ & $\mathrm{NI}$ \\
\hline 173 & 844 & R. MARCUS PEREIRA, 37 & Residencial & Outras & 7386420 & 323020 & 825 & $\mathrm{NI}$ & nao confiavel & 265 & 0,4 & 21 & 139 & 0,4 & 139 & 20 \\
\hline 174 & 931 & R. JOAQUIM CANDIDO A.MARQUES, 1429 & Residencial & Sondagua & 7387640 & 325810 & 760 & $13 / 09 / 2001$ & misto2 & 206 & 1,3 & 18 & 174 & 1,3 & 170 & 20 \\
\hline 175 & $\mathrm{NI}$ & R. MARATONA , 161 & Residencial & $\mathrm{NI}$ & 7384410 & 329610 & $\mathrm{NI}$ & $10 / 05 / 2000$ & nao confiavel & $\mathrm{NI}$ & NI & $\mathrm{NI}$ & $\mathrm{NI}$ & NI & $\mathrm{NI}$ & $\mathrm{NI}$ \\
\hline 176 & 1179 & R. PENSILVANIA, 354 & Residencial & Garca Pocos & 7387270 & 328570 & 734 & $12 / 12 / 2002$ & nao confiavel & 250 & 7,0 & 12 & 126 & 7,0 & 12 & 5 \\
\hline 177 & 779 & R. PROF.ALEXANDRE CORRE, 620 & Residencial & Outras & 7386720 & 324550 & 760 & NI & nao confiavel & 200 & 2,2 & 7 & 120 & 2,2 & 120 & 20 \\
\hline 178 & $\mathrm{NI}$ & R. PROF. ALEXANDRE CORREA, 360 & Residencial & $\mathrm{NI}$ & 7386490 & 324570 & $\mathrm{NI}$ & $\mathrm{NI}$ & cristalino & $\mathrm{NI}$ & $\mathrm{NI}$ & $\mathrm{NI}$ & $\mathrm{NI}$ & $\mathrm{NI}$ & $\mathrm{NI}$ & $\mathrm{NI}$ \\
\hline 179 & $\mathrm{NI}$ & R. SOCRATES, 625 & Residencial & $\mathrm{NI}$ & 7382490 & 327540 & $\mathrm{NI}$ & $10 / 10 / 2000$ & sedimentar & $\mathrm{NI}$ & $\mathrm{NI}$ & $\mathrm{NI}$ & $\mathrm{NI}$ & $\mathrm{NI}$ & $\mathrm{NI}$ & $\mathrm{NI}$ \\
\hline 180 & $\mathrm{NI}$ & R. FABIO LOPES SANTOS LUZ, 60 & Residencial & $\mathrm{NI}$ & 7385510 & 323400 & $\mathrm{NI}$ & $\mathrm{NI}$ & nao confiavel & $\mathrm{NI}$ & $\mathrm{NI}$ & $\mathrm{NI}$ & $\mathrm{NI}$ & $\mathrm{NI}$ & $\mathrm{NI}$ & $\mathrm{NI}$ \\
\hline
\end{tabular}




\begin{tabular}{|c|c|c|c|c|c|c|c|c|c|c|c|c|c|c|c|c|}
\hline \multicolumn{17}{|c|}{ ANEXO - CADASTRO DE POÇOS - Continuação } \\
\hline \begin{tabular}{|l} 
No.-de- \\
poços
\end{tabular} & $\begin{array}{l}\text { Poco_ } \\
\text { DAEEE }\end{array}$ & Endereco & Atividade & Cia_Perfuradora & N & E & $\mid \operatorname{cota}(\mathrm{m})$ & Data_Const & Aquifero & Prof-(m) & \begin{tabular}{|l|} 
Teste- \\
Vazao- \\
(m3/h)
\end{tabular} & \begin{tabular}{|l|} 
TesteN \\
$\mathrm{E}(\mathrm{m})$
\end{tabular} & \begin{tabular}{|l|} 
TesteN \\
$\mathrm{D}(\mathrm{m})$
\end{tabular} & \begin{tabular}{|l|} 
Vazao- \\
Explor- \\
(m3/h)
\end{tabular} & \begin{tabular}{|l} 
ND- \\
explor- \\
(m)
\end{tabular} & $\begin{array}{l}\text { Horas- } \\
\text { Exp }\end{array}$ \\
\hline 181 & $\mathrm{NI}$ & R. FABIO LOPES SANTOS LUZ, 60 & Residencial & $\mathrm{NI}$ & 7385420 & 323410 & $\mathrm{NI}$ & $\mathrm{NI}$ & nao confiavel & $\mathrm{NI}$ & $\mathrm{NI}$ & $\mathrm{NI}$ & $\mathrm{NI}$ & 4,0 & $\mathrm{NI}$ & 20 \\
\hline 182 & $\mathrm{NI}$ & AV. SARGENTO GERALDO SANT'ANA, 1100 & Residencial & $\mathrm{NI}$ & 7381660 & 328410 & $\mathrm{NI}$ & $02 / 09 / 2000$ & nao confiavel & $\mathrm{NI}$ & $\mathrm{NI}$ & $\mathrm{NI}$ & $\mathrm{NI}$ & $\mathrm{NI}$ & $\mathrm{NI}$ & $\mathrm{NI}$ \\
\hline 183 & $\mathrm{NI}$ & AV. INTERLAGOS, 492 & Residencial & $\mathrm{NI}$ & 7382600 & 328480 & $\mathrm{NI}$ & $19 / 04 / 2000$ & nao confiavel & $\mathrm{NI}$ & $\mathrm{NI}$ & $\mathrm{NI}$ & $\mathrm{NI}$ & 18,0 & $\mathrm{NI}$ & 20 \\
\hline 184 & $\mathrm{NI}$ & AV. INTERLAGOS, 492 & Residencial & $\mathrm{NI}$ & 7382580 & 328280 & $\mathrm{NI}$ & $24 / 05 / 1999$ & nao confiavel & $\mathrm{NI}$ & $\mathrm{NI}$ & $\mathrm{NI}$ & $\mathrm{NI}$ & $\mathrm{NI}$ & $\mathrm{NI}$ & $\mathrm{NI}$ \\
\hline 185 & $\mathrm{NI}$ & ESTRADA M'BOI MIRIM , 820 & Residencial & $\mathrm{NI}$ & 7381170 & 322500 & $\mid \mathrm{NI}$ & $08 / 04 / 2004$ & nao confiavel & $\mathrm{NI}$ & $\mathrm{NI}$ & $\mathrm{NI}$ & $\mathrm{NI}$ & 3,0 & $\mathrm{NI}$ & 4 \\
\hline 186 & 740 & R. DR. JAMES FERRAZ ALVIM, 271 & Residencial & \begin{tabular}{|l} 
Jundsondas \\
\end{tabular} & 7387210 & 323260 & 815 & $28 / 01 / 2000$ & nao confiavel & 230 & 5,5 & 32 & 119 & 5,5 & 119 & 11 \\
\hline 187 & 1399 & R. JOSE GALANTE, 224 & Residencial & \begin{tabular}{|l|} 
Jundsondas \\
\end{tabular} & 7386920 & 323140 & 820 & $06 / 06 / 2001$ & nao confiavel & 189 & 6,0 & 38 & 139 & 6,0 & 139 & 6 \\
\hline 188 & $\mathrm{NI}$ & R. JOSE GALANTE, 224 & Residencial & $\mathrm{NI}$ & 7386910 & 323100 & $\mathrm{NI}$ & $\mathrm{NI}$ & nao confiavel & $\mathrm{NI}$ & $\mathrm{NI}$ & $\mathrm{NI}$ & $\mathrm{NI}$ & $\mathrm{NI}$ & $\mathrm{NI}$ & $\mathrm{NI}$ \\
\hline 189 & $\mathrm{NI}$ & AV. JOSE GALANTE, 671 & Residencial & $\mathrm{NI}$ & 7386620 & 322760 & $\mathrm{NI}$ & $\mathrm{NI}$ & nao confiavel & $\mathrm{NI}$ & $\mathrm{NI}$ & $\mathrm{NI}$ & $\mathrm{NI}$ & 3,0 & $\mathrm{NI}$ & 20 \\
\hline 190 & $\mid \mathrm{NI}$ & R. DANAIDES, 53 & Residencial & $\mathrm{NI}$ & 7382060 & 327390 & $\mathrm{NI}$ & $\mathrm{NI}$ & nao confiavel & $\mathrm{NI}$ & $\mathrm{NI}$ & $\mathrm{NI}$ & $\mathrm{NI}$ & $\mathrm{NI}$ & $\mathrm{NI}$ & $\mathrm{NI}$ \\
\hline 191 & $\mathrm{NI}$ & R. ALBA, 2088 & \begin{tabular}{|l|} 
Residencial \\
\end{tabular} & $\mathrm{NI}$ & 7383250 & 330240 & $\mathrm{NI}$ & $27 / 09 / 1997$ & nao confiavel & $\mathrm{NI}$ & $\mathrm{NI}$ & $\mathrm{NI}$ & $\mathrm{NI}$ & 15,0 & $\mathrm{NI}$ & 20 \\
\hline 192 & $\mathrm{NI}$ & R. ALBA, 2140 & $\begin{array}{l}\text { Residencial } \\
\end{array}$ & $\mathrm{NI}$ & 7383190 & 330220 & $\mathrm{NI}$ & $28 / 02 / 1998$ & nao confiavel & $\mathrm{NI}$ & $\mathrm{NI}$ & $\mathrm{NI}$ & $\mathrm{NI}$ & $\mathrm{NI}$ & $\mathrm{NI}$ & $\mathrm{NI}$ \\
\hline 193 & $\mathrm{NI}$ & AL. DOS TUPINIQUINS, 786 & Residencial & $\mathrm{NI}$ & 7387990 & 330900 & $\mathrm{NI}$ & $14 / 12 / 2001$ & nao confiavel & $\mathrm{NI}$ & $\mathrm{NI}$ & $\mathrm{NI}$ & $\mathrm{NI}$ & $\mathrm{NI}$ & $\mathrm{NI}$ & $\mathrm{NI}$ \\
\hline 194 & 904 & R. LACEDEMONIA, 392 & Residencial & Aguasonda & 7384690 & 329660 & 782 & $28 / 09 / 2001$ & sedimentar & 106 & 0,7 & 61 & 80 & 0,7 & 80 & 20 \\
\hline 195 & 989 & R. BARAO DO TRIUNFO, 1176 & Residencial & \begin{tabular}{|l} 
Aguasonda \\
\end{tabular} & 7386930 & 328800 & 751 & $28 / 03 / 2002$ & sedimentar & 111 & 0,4 & 28 & 48 & 0,4 & 48 & 20 \\
\hline 196 & $\mathrm{NI}$ & R. BARAO DO TRIUNFO, 1528 & Residencial & $\mathrm{NI}$ & 7387200 & 329020 & $\mathrm{NI}$ & $29 / 01 / 2005$ & nao confiavel & $\mathrm{NI}$ & $\mathrm{NI}$ & $\mathrm{NI}$ & $\mathrm{NI}$ & 3,0 & $\mathrm{NI}$ & 10 \\
\hline 197 & 1513 & AV. VEREADOR. JOSE DINIZ, 1308 & Residencial & Saiagua & 7385440 & 327630 & 750 & $07 / 04 / 2005$ & cristalino & 315 & 4,8 & 32 & 196 & 4,8 & 196 & 12 \\
\hline 198 & 1264 & R. VOLTA REDONDA, 757 & Residencial & Outras & 7386020 & 329470 & 765 & $18 / 05 / 2003$ & sedimentar & 91 & 4,8 & 25 & 31 & 2,0 & 31 & 18 \\
\hline 199 & $\mathrm{NI}$ & R. JOSE ANDRADE FIGUEIRA, 500 & Residencial & $\mathrm{NI}$ & 7387010 & 322360 & $\mathrm{NI}$ & \begin{tabular}{|l|}
$\mathrm{NI}$ \\
\end{tabular} & nao confiavel & $\mathrm{NI}$ & $\mathrm{NI}$ & $\mathrm{NI}$ & $\mathrm{NI}$ & 7,5 & $\mathrm{NI}$ & 6 \\
\hline 200 & $\mathrm{NI}$ & R. DR. JOSE FIGUEIRA, 220 & Residencial & $\mathrm{NI}$ & 7387140 & 322600 & $\mathrm{NI}$ & $\mathrm{NI}$ & nao confiavel & $\mathrm{NI}$ & $\mathrm{NI}$ & $\mathrm{NI}$ & $\mathrm{NI}$ & $\mathrm{NI}$ & $\mathrm{NI}$ & $\mathrm{NI}$ \\
\hline 201 & $\mathrm{NI}$ & R. EDSON, 159 & Residencial & $\mathrm{NI}$ & 7387090 & 328600 & $\mathrm{NI}$ & $\mathrm{NI}$ & nao confiavel & $\mathrm{NI}$ & $\mathrm{NI}$ & $\mathrm{NI}$ & $\mathrm{NI}$ & $\mathrm{NI}$ & $\mathrm{NI}$ & $\mathrm{NI}$ \\
\hline 202 & $\mathrm{NI}$ & R. GIL EANES, 373 & Residencial & $\mathrm{NI}$ & 7387410 & 328810 & $\mathrm{NI}$ & $02 / 09 / 2000$ & nao confiavel & $\mathrm{NI}$ & $\mathrm{NI}$ & $\mathrm{NI}$ & $\mathrm{NI}$ & $\mathrm{NI}$ & $\mathrm{NI}$ & $\mathrm{NI}$ \\
\hline 203 & $\mathrm{NI}$ & R. ASCENCIONAL, 34 & Residencial & $\mathrm{NI}$ & 7386440 & 323170 & $\mathrm{NI}$ & $05 / 12 / 1997$ & nao confiavel & $\mathrm{NI}$ & $\mathrm{NI}$ & $\mathrm{NI}$ & $\mathrm{NI}$ & $\mathrm{NI}$ & $\mathrm{NI}$ & $\mathrm{NI}$ \\
\hline 204 & 170 & R. MADRE RITA AMADA JESUS, 72 & Residencial & T. Janer & 7384520 & 326630 & 753 & $10 / 03 / 1980$ & cristalino & 150 & 11,0 & 38 & 58 & $\mathrm{NI}$ & $\mathrm{NI}$ & $\mathrm{NI}$ \\
\hline 205 & 161 & R. GIL EANES,45 & Residencial & $\mathrm{NI}$ & 7387110 & 328620 & 747 & $01 / 12 / 1994$ & cristalino & 0 & $\mathrm{NI}$ & $\mathrm{NI}$ & $\mathrm{NI}$ & $\mathrm{NI}$ & $\mathrm{NI}$ & $\mathrm{NI}$ \\
\hline 206 & 1327 & R. EDISON, 30 & Residencial & Aguasonda & 7387110 & 328560 & 745 & $20 / 01 / 2004$ & nao confiavel & 155 & 4,0 & 28 & 84 & 4,0 & 84 & 20 \\
\hline 207 & 307 & R. CHIBATA MIYAKOSHI,300 & \begin{tabular}{|l|} 
Residencial \\
\end{tabular} & \begin{tabular}{|l|} 
Aguabras \\
\end{tabular} & 7386130 & 324330 & 769 & $11 / 11 / 1995$ & \begin{tabular}{|l|} 
cristalino \\
\end{tabular} & 200 & 4,5 & 77 & 162 & 4,5 & $\mathrm{NI}$ & 15 \\
\hline 208 & $\mathrm{NI}$ & R. JAMANARI ,215 & Residencial & $\mathrm{NI}$ & 7385750 & 322990 & $\mathrm{NI}$ & $30 / 09 / 2004$ & nao confiavel & $\mathrm{NI}$ & $\mathrm{NI}$ & $\mathrm{NI}$ & $\mathrm{NI}$ & 5,0 & $\mathrm{NI}$ & 5 \\
\hline 209 & $\mathrm{NI}$ & AV. GIOVANNI GRONCHI , 486 & Residencial & $\mathrm{NI}$ & 7386430 & 323120 & $\mathrm{NI}$ & $25 / 06 / 2004$ & nao confiavel & $\mathrm{NI}$ & $\mathrm{NI}$ & $\mathrm{NI}$ & $\mathrm{NI}$ & 4,0 & $\mathrm{NI}$ & $\mathrm{NI}$ \\
\hline 210 & $\mathrm{NI}$ & R. DR. CHIOBATA MIYAKOSHI, 17 & Residencial & $\mathrm{NI}$ & 7386140 & 324200 & $\mathrm{NI}$ & NI & nao confiavel & $\mathrm{NI}$ & $\mathrm{NI}$ & $\mathrm{NI}$ & $\mathrm{NI}$ & 3,0 & $\mathrm{NI}$ & 5 \\
\hline 211 & $\mathrm{NI}$ & AV. PEDRINA MARIA DA SILVA VALENTE, 44 & Residencial & $\mathrm{NI}$ & 7383540 & 319830 & $\mathrm{NI}$ & $\mathrm{NI}$ & nao confiavel & $\mathrm{NI}$ & $\mathrm{NI}$ & $\mathrm{NI}$ & $\mathrm{NI}$ & 2,0 & 20 & $\mathrm{NI}$ \\
\hline 212 & $\mathrm{NI}$ & R. ALVARO LUIZ ASSUNCAO, 161 & Residencial & $\mathrm{NI}$ & 7387160 & 328720 & $\mathrm{NI}$ & $\mathrm{NI}$ & nao confiavel & $\mathrm{NI}$ & $\mathrm{NI}$ & $\mathrm{NI}$ & $\mathrm{NI}$ & 1,5 & $\mathrm{NI}$ & 20 \\
\hline 213 & 310 & R. AMERICO ALVES PEREIRA FILHO,531 & Residencial & Geoplan & 7387920 & 326060 & 804 & $01 / 01 / 1997$ & cristalino & 150 & 18,0 & 11 & 85 & 18,0 & $\mathrm{NI}$ & 18 \\
\hline 214 & 789 & \begin{tabular}{|l|} 
R. AMERICO A.P.FILHO, 565 \\
\end{tabular} & Residencial & Jundsondas & 7387780 & 326100 & 745 & $22 / 11 / 1999$ & nao confiavel & 198 & 23,5 & 1 & 96 & 23,5 & 96 & 3 \\
\hline 215 & 806 & R. AMERICO ALVES PEREIRA FILHO,57 & Residencial & \begin{tabular}{|l|} 
Jundsondas \\
\end{tabular} & 7387820 & 326170 & 736 & $28 / 09 / 1999$ & nao confiavel & 216 & 8,0 & 11 & 51 & 8,0 & 51 & 9 \\
\hline 216 & 1356 & R. AMERICO ALVES PEREIRA FILHO, 147 & Residencial & \begin{tabular}{|l|} 
Jundsondas \\
\end{tabular} & 7387880 & 326140 & 730 & $22 / 06 / 2000$ & nao confiavel & 170 & 9,8 & 19 & 93 & 6,0 & 93 & 9 \\
\hline 217 & 811 & R. VERBO DIVINO, 1323 & Residencial & Aguabras & 7385440 & 325810 & 728 & NI & misto2 & 150 & 8,0 & 14 & 76 & 8,0 & 76 & 20 \\
\hline 218 & $\mathrm{NI}$ & AV. ROQUE PETRONI JUNIOR., 999 & Residencial & NI & 7386410 & 326950 & $\mathrm{NI}$ & $20 / 04 / 2005$ & nao confiavel & $\mathrm{NI}$ & $\mathrm{NI}$ & $\mathrm{NI}$ & $\mathrm{NI}$ & 5,0 & $\mathrm{NI}$ & 20 \\
\hline 219 & $\mathrm{NI}$ & AV. SARGENTO GERALDO SANTANA, 1100 & Residencial & $\mathrm{NI}$ & $\mathrm{NI}$ & $\mathrm{NI}$ & $\mathrm{NI}$ & $\mathrm{NI}$ & $\mathrm{NI}$ & $\mathrm{NI}$ & $\mathrm{NI}$ & $\mathrm{NI}$ & $\mathrm{NI}$ & $\mathrm{NI}$ & $\mathrm{NI}$ & $\mathrm{NI}$ \\
\hline 220 & 1253 & R. MALLHASTINFILO DE MOURA, 338 & Residencial & $\mathrm{NI}$ & 7387280 & 322730 & 758 & $\mathrm{NI}$ & nao confiavel & 153 & 12,0 & 6 & 38 & 12,0 & 38 & 16 \\
\hline 221 & 1254 & R. MAL HASTINFILO DE MOURA, 338 & Residencial & $\mathrm{NI}$ & 7387530 & 322990 & 790 & $\mathrm{NI}$ & nao confiavel & 265 & 9,0 & 69 & 110 & 9,0 & 110 & 16 \\
\hline 222 & 1255 & R. MAL.HASTINFLLO DE MOURA, 338 & Residencial & $\mathrm{NI}$ & 7387230 & 322790 & 767 & $\mathrm{NI}$ & nao confiavel & 247 & 12,0 & 22 & 60 & 12,0 & 60 & 16 \\
\hline 223 & 1256 & R. MAL.HASTINFILO DE MOURA, 338 & \begin{tabular}{|l|} 
Residencial \\
\end{tabular} & $\mathrm{NI}$ & 7387340 & 322510 & 757 & $\mathrm{NI}$ & nao confiavel & 200 & 7,4 & 3 & 100 & 7,4 & 100 & 16 \\
\hline 224 & 1257 & R, MALL. HASTINFILO DE MOURA, 338 & Residencial & $\mathrm{NI}$ & 7387410 & 322390 & 756 & $\mathrm{NI}$ & nao confiavel & 166 & 14,0 & 12 & 36 & 14,0 & 36 & 16 \\
\hline 225 & 1258 & R. MAL.HASTINFILO DE MOURA, 338 & Residencial & $\mathrm{NI}$ & 7387260 & 322940 & 790 & $\mathrm{NI}$ & nao confiavel & 0 & $\mathrm{NI}$ & $\mathrm{NI}$ & $\mathrm{NI}$ & $\mathrm{NI}$ & $\mathrm{NI}$ & $\mathrm{NI}$ \\
\hline
\end{tabular}




\begin{tabular}{|c|c|c|c|c|c|c|c|c|c|c|c|c|c|c|c|c|}
\hline \multicolumn{17}{|c|}{ ANEXO - CADASTRO DE POÇOS - Continuação } \\
\hline \begin{tabular}{|l} 
No.-de- \\
poços
\end{tabular} & $\begin{array}{l}\text { Poco_ } \\
\text { DAEEE }\end{array}$ & Endereco & Atividade & Cia_Perfuradora & $\mathbf{N}$ & E & Cota $(\mathrm{m}) \mid$ & Data_Const & Aquifero & Prof-(m) & \begin{tabular}{|l|} 
Teste- \\
Vazao- \\
(m3/h)
\end{tabular} & \begin{tabular}{|l|} 
TesteN \\
$\mathrm{E}(\mathrm{m})$
\end{tabular} & \begin{tabular}{|l|} 
Testen \\
$\mathrm{D}(\mathrm{m})$
\end{tabular} & \begin{tabular}{|l|} 
Vazao- \\
Explor- \\
(m3/h)
\end{tabular} & \begin{tabular}{|l} 
ND- \\
explor- \\
(m)
\end{tabular} & $\begin{array}{l}\text { Horas- } \\
\text { Exp }\end{array}$ \\
\hline 226 & 1259 & R. MAL.HASTINFLLO DE MOURA, 338 & Residencial & $\mathrm{NI}$ & 7387230 & 322550 & 752 & $\mathrm{NI}$ & nao confiavel & 0 & $\mathrm{NI}$ & $\mathrm{NI}$ & $\mathrm{NI}$ & $\mathrm{NI}$ & $\mathrm{NI}$ & $\mathrm{NI}$ \\
\hline 227 & 1260 & R. MALL.HASTINFILO DE MOURA, 338 & Residencial & $\mathrm{NI}$ & 7387290 & 322440 & 752 & $\mathrm{NI}$ & nao confiavel & 0 & $\mathrm{NI}$ & $\mathrm{NI}$ & $\mathrm{NI}$ & $\sqrt{\mathrm{NI}}$ & $\mathrm{NI}$ & $\mathrm{NI}$ \\
\hline 228 & $\mathrm{NI}$ & R, MAL. HASTINFILO DE MOURA, 338 & Residencial & $\mathrm{NI}$ & 7387230 & 322550 & $\mathrm{NI}$ & $\mathrm{NI}$ & nao confiavel & $\mathrm{NI}$ & $\mathrm{NI}$ & $\mathrm{NI}$ & $\mathrm{NI}$ & $\mathrm{NI}$ & $\mathrm{NI}$ & $\mathrm{NI}$ \\
\hline 229 & 1219 & R. DR. LUIZ MIGLIANO, 1100 & Residencial & Jundsondas & 7387390 & 322220 & 750 & $04 / 02 / 2003$ & nao confiavel & 180 & 6,0 & 34 & 57 & 6,0 & 57 & 6 \\
\hline 230 & $\mathrm{NI}$ & R. DR. LUIZ MIGLIANO, 1100 & Residencial & $\mathrm{NI}$ & 7387450 & 322170 & $\mathrm{NI}$ & $\mathrm{NI}$ & nao confiavel & $\mathrm{NI}$ & $\mathrm{NI}$ & $\mathrm{NI}$ & $\mathrm{NI}$ & $\mathrm{NI}$ & $\mathrm{NI}$ & $\mathrm{NI}$ \\
\hline 231 & 1573 & R. DOUTOR. FERREIRA LOPES, 317 & Residencial & SP Pocos & 7382650 & 327150 & 748 & $10 / 05 / 2005$ & misto 3 & 180 & 8,5 & 65 & 80 & 5,0 & 80 & 16 \\
\hline 232 & 177 & AV. WASHINGTON LUIS, 1576 & Residencial & Air Lift & 7382900 & 327700 & 765 & $06 / 03 / 1990$ & misto 1 & 111 & 8,8 & 45 & 56 & $\mathrm{NI}$ & $\mathrm{NI}$ & $\mathrm{NI}$ \\
\hline 233 & 191 & AV. WASHINGTON LUIZ, 1576 & Residencial & Air Lift & 7382900 & 327580 & 780 & $25 / 08 / 1988$ & misto 1 & 90 & 4,0 & 42 & 58 & $\mathrm{NI}$ & $\mathrm{NI}$ & $\mathrm{NI}$ \\
\hline 234 & 401 & AV. WASHINGTON LUIS, 1576 & Residencial & Hidrogesp & 7382900 & 327930 & 755 & $19 / 04 / 1996$ & nao confiavel & 104 & 4,4 & 12 & 64 & 4,5 & 66 & 18 \\
\hline 235 & 402 & AV. WASHINGTON LUIS, 1576 & Residencial & Hidrogesp & 7382800 & 327780 & 750 & $30 / 10 / 1995$ & nao confiavel & 152 & 9,5 & 28 & 121 & 8,0 & 54 & 18 \\
\hline 236 & 403 & AV. WASHINGTON LUIS,1576 & Residencial & Hidrogesp & 7382850 & 327600 & 775 & $25 / 04 / 1996$ & nao confiavel & 204 & 11,6 & 37 & 41 & 11,6 & 45 & 20 \\
\hline 237 & 1321 & AV. WASHINGTON LUIS, 1576 & Residencial & Edisonda & 7382820 & 327850 & 750 & $30 / 12 / 2002$ & nao confiavel & 156 & 5,0 & 40 & 79 & 5,0 & 79 & 18 \\
\hline 238 & 1429 & R. JOAO PEIXOTO VIEGAS, 193 & Residencial & Hidrogeo & 7381510 & 329190 & 743 & $01 / 09 / 2004$ & nao confiavel & 252 & 7,2 & 67 & 147 & 10,0 & 179 & 20 \\
\hline 239 & 315 & R. ALBA, 2088 & Residencial & Aguabras & 738325 & 33024 & $\mathrm{NI}$ & $14 / 02 / 1997$ & cristalino & 123 & 14,4 & 39 & 72 & 15,0 & 73 & 20 \\
\hline 240 & 1249 & AV. GUARAPIRANGA, 752 & Shopping & Hidrogesp & 7381690 & 324650 & 724 & $26 / 11 / 1996$ & cristalino & 204 & 6,0 & 38 & 89 & 6,0 & 89 & 20 \\
\hline 241 & 1250 & AV. GUARAPIRANGA, 752 & Shopping & Hidroenge & 7381970 & 324340 & 724 & $06 / 11 / 1998$ & cristalino & 221 & 13,3 & 11 & 96 & $\mathrm{NI}$ & $\mathrm{NI}$ & $\mathrm{NI}$ \\
\hline 242 & 63 & AV. ROQUE PETRONI, 1089 & Residencial & Aguabras & 7386680 & 326750 & 724 & $20 / 02 / 1992$ & cristalino & 225 & $\mathrm{NI}$ & $\mathrm{NI}$ & $\mathrm{NI}$ & $\mathrm{NI}$ & $\mathrm{NI}$ & $\mathrm{NI}$ \\
\hline 243 & 566 & AV. GIOVANNI GRONCHI & Residencial & Outras & 7385500 & 322890 & 755 & $\mathrm{NI}$ & nao confiavel & 200 & 6,1 & 9 & 114 & 1,0 & 26 & 13 \\
\hline 244 & 567 & AV. GIOVANNI GRONCHI & Residencial & Outras & 7385480 & 322900 & 750 & $\mathrm{NI}$ & nao confiavel & 342 & 6,5 & 65 & 198 & 4,0 & 149 & 13 \\
\hline 245 & 694 & R. NELSON GAMA DE OLIVEIRA, 57 & Residencial & Garca Azul & 7385240 & 323200 & 770 & $20 / 07 / 2000$ & nao confiavel & 300 & 3,0 & 48 & 230 & 2,5 & 226 & 20 \\
\hline 246 & 254 & AV. DAS NACOES UNIDAS, 22540 & Shopping (posto de gasol.) & Corner & 7380400 & 326540 & 727 & $08 / 01 / 1976$ & cristalino & 287 & 2,9 & 108 & 121 & $\mathrm{NI}$ & $\mathrm{NI}$ & $\mathrm{NI}$ \\
\hline 247 & 255 & AV. DAS NACOES UNIDAS, 22540 & Shopping (posto de gasol.) & Corner & 7380180 & 326710 & 724 & $\mathrm{NI}$ & cristalino & 300 & 4,1 & 80 & 144 & $\mathrm{NI}$ & $\mathrm{NI}$ & $\mathrm{NI}$ \\
\hline 248 & 256 & AV. DAS NACOES UNIDAS, 22540 & Shopping (posto de gasol.) & Corner & 7380560 & 326740 & 723 & $03 / 06 / 1987$ & cristalino & 300 & 11,7 & 64 & 92 & $\mathrm{NI}$ & $\mathrm{NI}$ & $\mathrm{NI}$ \\
\hline 249 & 1113 & AV. DAS NACOES UNIDAS, 22540 & Shopping (posto de gasol.) & \begin{tabular}{|l} 
Jundsondas \\
\end{tabular} & 7380040 & 326850 & 724 & $12 / 01 / 2002$ & cristalino & 320 & 0,7 & 116 & 126 & $\mathrm{NI}$ & $\mathrm{NI}$ & $\mathrm{NI}$ \\
\hline 250 & 1204 & AV. DAS NACOES UNIDAS, 22540 & Shopping (posto de gasol.) & Outras & 7380250 & 327020 & 724 & $23 / 09 / 2002$ & nao confiavel & 261 & 14,4 & 99 & 195 & 14,4 & 195 & 20 \\
\hline 251 & $\mathrm{NI}$ & AV. DAS NACOES UNIDAS, 22540 & Shopping (posto de gasol.) & $\mathrm{NI}$ & 7380180 & 326710 & $\mathrm{NI}$ & $\mathrm{NI}$ & $\mathrm{NI}$ & $\mathrm{NI}$ & $\mathrm{NI}$ & $\mathrm{NI}$ & $\mathrm{NI}$ & $\mathrm{NI}$ & $\mathrm{NI}$ & $\mathrm{NI}$ \\
\hline 252 & $\mathrm{NI}$ & R. DO SIMBOLO, 133 & Residencial & $\mathrm{NI}$ & 7386320 & 323580 & $\mathrm{NI}$ & $16 / 08 / 2001$ & nao confiavel & $\mathrm{NI}$ & $\mathrm{NI}$ & $\mathrm{NI}$ & $\mathrm{NI}$ & $\mathrm{NI}$ & $\mathrm{NI}$ & $\mathrm{NI}$ \\
\hline 253 & 235 & R. LIRA CEARENSE,458 & Residencial & $\mathrm{NI}$ & 7384390 & 320930 & 792 & $14 / 05 / 2001$ & cristalino & 270 & 1,7 & 20 & 208 & 1,7 & 208 & 20 \\
\hline 254 & $\mathrm{NI}$ & R. CANCIONEIRO POPULAR., 480 & Residencial & $\mathrm{NI}$ & 7385840 & 327240 & $\mathrm{NI}$ & $22 / 06 / 2004$ & nao confiavel & $\mathrm{NI}$ & $\mathrm{NI}$ & $\mathrm{NI}$ & $\mathrm{NI}$ & 5,0 & $\mathrm{NI}$ & 20 \\
\hline 255 & $\mathrm{NI}$ & ESTRADA DA RIVIERA, 4742 & Residencial & $\mathrm{NI}$ & 7377180 & 322450 & $\mathrm{NI}$ & $13 / 08 / 1999$ & nao confiavel & $\mathrm{NI}$ & $\mathrm{NI}$ & $\mathrm{NI}$ & $\mathrm{NI}$ & $\mathrm{NI}$ & $\mathrm{NI}$ & $\mathrm{NI}$ \\
\hline 256 & $\mathrm{NI}$ & $\mathrm{NI}$ & Residencial & $\mathrm{NI}$ & 7383230 & 328340 & $\mathrm{NI}$ & NI & $\mathrm{NI}$ & $\mathrm{NI}$ & $\mathrm{NI}$ & $\mathrm{NI}$ & $\mathrm{NI}$ & $\mathrm{NI}$ & $\mathrm{NI}$ & $\mathrm{NI}$ \\
\hline 257 & $\mathrm{NI}$ & R. DIEGO DE CASTILHO, 124 & empreendimentos imobiliarios & $\mathrm{NI}$ & 7385750 & 324380 & $\mathrm{NI}$ & $\mathrm{NI}$ & nao confiavel & $\mathrm{NI}$ & $\mathrm{NI}$ & $\mathrm{NI}$ & $\mathrm{NI}$ & 5,0 & $\mathrm{NI}$ & 10 \\
\hline 258 & 907 & AV. N.S..DO SABARA, 4900 & empreendimentos imobiliarios & Geoplan & 7378180 & 328760 & 723 & $12 / 04 / 2001$ & cristalino & 180 & 5,5 & 7 & 134 & 3,0 & 77 & 8 \\
\hline 259 & 274 & R. MINIISTRO NELSON HUNGRIA, 450 & Hoteis e similares & Jundsondas & 7387590 & 326160 & 752 & $14 / 10 / 1995$ & cristalino & 300 & 1,6 & 37 & 176 & $\mathrm{NI}$ & $\mathrm{NI}$ & 20 \\
\hline 260 & 322 & R. MIN. NELSON HUNGRIA, 450 & Hoteis e similares & Sondamar & 7387590 & 326220 & 740 & $11 / 10 / 1996$ & nao confiavel & 104 & 3,1 & 23 & 68 & $\mathrm{NI}$ & $\mathrm{NI}$ & $\mathrm{NI}$ \\
\hline 261 & $\mathrm{NI}$ & R. DOMINGO GONÇALO, 360 & Residencial & $\mathrm{NI}$ & $\mathrm{NI}$ & $\mathrm{NI}$ & $\mathrm{NI}$ & $\mathrm{NI}$ & nao confiavel & $\mathrm{NI}$ & $\mathrm{NI}$ & $\mathrm{NI}$ & $\mathrm{NI}$ & $\mathrm{NI}$ & $\mathrm{NI}$ & $\mathrm{NI}$ \\
\hline 262 & 1337 & AV. JOSE GALANTE, 512 & Imobiliaria & Jundsondas & 7386660 & 322820 & 833 & $04 / 12 / 2003$ & nao confiavel & 295 & 4,8 & 69 & 149 & 4,8 & 149 & 10 \\
\hline 263 & 143 & EST. DA RIVIERA, 1939 & Residencial & $\mathrm{NI}$ & 7378860 & 321450 & 744 & $\mathrm{NI}$ & $\mathrm{NI}$ & 0 & $\mathrm{NI}$ & $\mathrm{NI}$ & $\mathrm{NI}$ & $\mathrm{NI}$ & $\mathrm{NI}$ & $\mathrm{NI}$ \\
\hline 264 & 257 & EST.DA RIVIERA, 1975 & Residencial & $\mathrm{NI}$ & 7379370 & 321360 & 745 & $\mathrm{NI}$ & $\mathrm{NI}$ & 0 & 15,0 & $\mathrm{NI}$ & $\mathrm{NI}$ & 15,0 & $\mathrm{NI}$ & 20 \\
\hline 265 & $\mathrm{NI}$ & R. ANTONIO DE ANDRADE RABELO, 754 & Residencial & $\mathrm{NI}$ & 7386970 & 325510 & $\mathrm{NI}$ & $22 / 06 / 2004$ & nao confiavel & $\mathrm{NI}$ & $\mathrm{NI}$ & $\mathrm{NI}$ & $\mathrm{NI}$ & 2,0 & $\mathrm{NI}$ & 3 \\
\hline 266 & 1679 & R. GALEANO DE CASTRO, 321 & Textil & $\mathrm{NI}$ & 7381830 & 326120 & 727 & $>20$ anos & cristalino & 201 & 8,0 & 88 & 98 & 8,0 & 98 & 20 \\
\hline 267 & $\mathrm{NI}$ & R. HEITOR. PORTUGAL, 174 & Residencial & $\mathrm{NI}$ & 7387030 & 325500 & $\mathrm{NI}$ & $\mathrm{NI}$ & nao confiavel & $\mathrm{NI}$ & $\mathrm{NI}$ & $\mathrm{NI}$ & $\mathrm{NI}$ & $\mathrm{NI}$ & $\mathrm{NI}$ & $\mathrm{NI}$ \\
\hline 268 & 1143 & R. MINISTRO ALVARO DE SOUZA LIMA, 101 & Imobiliaria & Garca Pocos & 7382610 & 327920 & 725 & $10 / 07 / 2000$ & nao confiavel & 301 & 3,2 & 70 & 210 & 3,2 & 210 & 3 \\
\hline 269 & 178 & R. LAGRANGE, 171 & Metalurgica (autopecas) & Outras & 7382100 & 324700 & 725 & $20 / 12 / 1994$ & cristalino & 106 & 33,0 & 6 & 43 & 33,0 & 37 & 1 \\
\hline 270 & 1117 & R. AMARO LUZ, 185 - PARTE & Quimica & Hidrogesp & 7381250 & 325390 & 728 & $\mathrm{NI}$ & cristalino & 200 & 7,2 & 77 & 138 & 5,0 & 138 & 16 \\
\hline
\end{tabular}




\begin{tabular}{|c|c|c|c|c|c|c|c|c|c|c|c|c|c|c|c|c|}
\hline \multicolumn{17}{|c|}{ ANEXO - CADASTRO DE POÇOS - Continuação } \\
\hline \begin{tabular}{|l} 
No.-de- \\
poços
\end{tabular} & $\begin{array}{l}\text { Poco_ } \\
\text { DAEEE }\end{array}$ & Endereco & Atividade & Cia_Perfuradora & $\mathbf{N}$ & $\mathrm{E}$ & Cota $(\mathrm{m}) \mid$ & Data_Const & Aquifero & Prof-(m) & \begin{tabular}{|l|} 
Teste- \\
Vazao- \\
(m3/h)
\end{tabular} & \begin{tabular}{|l|} 
TesteN \\
$\mathrm{E}(\mathrm{m})$
\end{tabular} & \begin{tabular}{|l|} 
TesteN \\
$\mathrm{D}(\mathrm{m})$
\end{tabular} & \begin{tabular}{|l|} 
Vazao- \\
Explor- \\
(m3/h)
\end{tabular} & \begin{tabular}{|l} 
ND- \\
explor- \\
(m)
\end{tabular} & $\begin{array}{l}\text { Horas- } \\
\text { Exp }\end{array}$ \\
\hline 271 & $\mathrm{NI}$ & R. COLEGIO PIO XII, 231 & Educacao & $\mathrm{NI}$ & 7386730 & 325170 & $\mathrm{NI}$ & $14 / 11 / 2002$ & nao confiavel & $\mathrm{NI}$ & $\mathrm{NI}$ & $\mathrm{NI}$ & $\mathrm{NI}$ & $\mathrm{NI}$ & $\mathrm{NI}$ & $\mathrm{NI}$ \\
\hline 272 & 280 & R. OLIVIA GUEDES PENTEADO, 375 & Fabricacao alimentíicios & $\mathrm{NI}$ & 7381230 & 325550 & 727 & $\mathrm{NI}$ & cristalino & 200 & $\mathrm{NI}$ & $\mathrm{NI}$ & $\mathrm{NI}$ & $\mathrm{NI}$ & $\mathrm{NI}$ & $\mathrm{NI}$ \\
\hline 273 & 1426 & AV. JOAO PAULO DA SILVA, 258 & Metalurgica & Geoplan & 7378440 & 327120 & 738 & mar-98 & cristalino & 258 & 5,1 & 18 & 145 & 4,0 & 145 & 20 \\
\hline 274 & $\mathrm{NI}$ & R. ARNALDO MAGNICARRO, 230 & Metalurgica & $\mathrm{NI}$ & 7380480 & 326980 & $\mathrm{NI}$ & $\mathrm{NI}$ & $\mathrm{NI}$ & $\mathrm{NI}$ & $\mathrm{NI}$ & $\mathrm{NI}$ & $\mathrm{NI}$ & $\mathrm{NI}$ & $\mathrm{NI}$ & $\mathrm{NI}$ \\
\hline 275 & 356 & R. JOAO FRANCISCO DELMAS, 117 & limpeza urbana & $\mathrm{NI}$ & 7383100 & 320290 & 754 & jan-94 & cristalino & 163 & 0,4 & 6 & 134 & 0,4 & 134 & 15 \\
\hline 276 & $357 \mathrm{~B}$ & R. JOAO FRANCISCO DELMAS, 117 & limpeza urbana & $\mathrm{NI}$ & 7383020 & 320420 & 752 & $\mathrm{NI}$ & cristalino & 176 & 1,0 & 5 & 156 & 1,0 & 156 & 20 \\
\hline 277 & $\mathrm{NI}$ & R. HENRIQUE FAUSTO LANCELOTTI, 6333 & Hoteis e similares & $\mathrm{NI}$ & 7385960 & 330320 & $\mathrm{NI}$ & $31 / 03 / 2005$ & nao confiavel & $\mathrm{NI}$ & $\mathrm{NI}$ & $\mathrm{NI}$ & $\mathrm{NI}$ & 4,3 & $\mathrm{NI}$ & 20 \\
\hline 278 & 62 & R. VICENTE LEPORACE, 1221 & Residencial & Hidrogeo & 7386400 & 329500 & 765 & 19/03/1992 & sedimentar & 134 & 192,0 & 32 & 45 & $\mathrm{NI}$ & $\mathrm{NI}$ & $\mathrm{NI}$ \\
\hline 279 & 568 & R. ITAPIMIRUM, 246 & Residencial & Outras & 7385430 & 323240 & 790 & $\mathrm{NI}$ & nao confiavel & 265 & 3,3 & 30 & 176 & 3,3 & 176 & 5 \\
\hline 280 & 1481 & R. ITAAARA, 191 & Residencial & Jundsondas & 7385410 & 323380 & 760 & $22 / 10 / 2004$ & cristalino & 251 & 6,5 & 37 & 175 & 6,5 & 175 & 8 \\
\hline 281 & $\mathrm{NI}$ & R. MARIA ANTONIA LADALARDO, 101 & Residencial & $\mathrm{NI}$ & 7385670 & 324650 & $\mathrm{NI}$ & $\mathrm{NI}$ & nao confiavel & $\mathrm{NI}$ & $\mathrm{NI}$ & $\mathrm{NI}$ & $\mathrm{NI}$ & 5,0 & 12 & $\mathrm{NI}$ \\
\hline 282 & 107 & R. PROF. ALEXANDRE CORREA, 620 & Residencial & Air Lift & 7386760 & 324590 & 735 & $02 / 02 / 1991$ & \begin{tabular}{|l|} 
cristalino \\
\end{tabular} & 200 & 2,2 & 7 & 120 & $\mathrm{NI}$ & $\mathrm{NI}$ & $\mathrm{NI}$ \\
\hline 283 & 108 & R. PROF. ALEXANDRE CORREA, 360 & Residencial & Air Lift & 7386520 & 324580 & 765 & $01 / 01 / 1991$ & alterada & 170 & 1,0 & 32 & 134 & 1,0 & $\mathrm{NI}$ & 20 \\
\hline 284 & $\mathrm{NI}$ & R. DOMINGOS LOPES DA SILVA, 575 & Residencial & $\mathrm{NI}$ & 7386970 & 322680 & $\mathrm{NI}$ & NI & nao confiavel & $\mathrm{NI}$ & $\mathrm{NI}$ & $\mathrm{NI}$ & $\mathrm{NI}$ & 4,0 & $\mathrm{NI}$ & 20 \\
\hline 285 & $\mathrm{NI}$ & R. GABRIELLE DE ANNUNZZOO, 145 & \begin{tabular}{|l|} 
Residencial \\
\end{tabular} & $\mathrm{NI}$ & 7386960 & 328560 & $\mathrm{NI}$ & $\mathrm{NI}$ & nao confiavel & $\mathrm{NI}$ & $\mathrm{NI}$ & $\mathrm{NI}$ & $\mathrm{NI}$ & $\mathrm{NI}$ & $\mathrm{NI}$ & $\mathrm{NI}$ \\
\hline 286 & 115 & AV. DO RIO BONITO, 1109 & Metalurgica & $\mathrm{NI}$ & 7380000 & 326210 & 750 & $\mathrm{NI}$ & nao confiavel & 180 & 15,0 & 40 & 109 & 1,8 & 109 & 8 \\
\hline 287 & 1142 & R. LAGUNA, 457 & Fabricacao plastico & Sondagua & 7384910 & 324990 & 724 & $16 / 08 / 2002$ & cristalino & 90 & 9,0 & 11 & 36 & 9,0 & 36 & 5 \\
\hline 288 & $\mathrm{NI}$ & AV. N.S. DO SABARA, 5312 & Servicos de utilidade & $\mathrm{NI}$ & 7378280 & 329300 & $\mathrm{NI}$ & NI & nao confiavel & $\mathrm{NI}$ & $\mathrm{NI}$ & $\mathrm{NI}$ & $\mathrm{NI}$ & 6,0 & $\mathrm{NI}$ & 20 \\
\hline 289 & $\mathrm{NI}$ & AV. N.S. DO SABARA, 5312 & Servicos de utilidade & $\mathrm{NI}$ & 7378350 & 328700 & $\mathrm{NI}$ & $\mathrm{NI}$ & nao confiavel & $\mathrm{NI}$ & $\mathrm{NI}$ & $\mathrm{NI}$ & $\mathrm{NI}$ & 6,4 & $\mathrm{NI}$ & 20 \\
\hline 290 & $\mathrm{NI}$ & AV. N.S. DO SABARA, 5312 & Servicos de utilidade & $\mathrm{NI}$ & 7378250 & 329200 & $\mathrm{NI}$ & $\mathrm{NI}$ & nao confiavel & $\mathrm{NI}$ & $\mathrm{NI}$ & $\mathrm{NI}$ & $\mathrm{NI}$ & 5,9 & $\mathrm{NI}$ & 20 \\
\hline 291 & $\mathrm{NI}$ & AV. N.S. DO SABARA, 5312 & Servicos de utilidade & $\mathrm{NI}$ & 7377920 & 328780 & $\mathrm{NI}$ & $\mathrm{NI}$ & nao confiavel & $\mathrm{NI}$ & $\mathrm{NI}$ & $\mathrm{NI}$ & $\mathrm{NI}$ & 5,1 & $\mathrm{NI}$ & 20 \\
\hline 292 & 357 & AV. N.S. DO SABARA, 5312 & Servico de utilidade & $\mathrm{NI}$ & 7378280 & 329250 & 723 & $\mathrm{NI}$ & nao confiavel & 3 & 6,0 & $\mathrm{NI}$ & $\mathrm{NI}$ & 6,0 & $\mathrm{NI}$ & $\mathrm{NI}$ \\
\hline 293 & 358 & AV. N.S. DO SABARA, 5312 & Servico de utilidade & $\mathrm{NI}$ & 7377980 & 329440 & 733 & $22 / 05 / 1905$ & nao confiavel & 7 & 6,0 & $\mathrm{NI}$ & $\mathrm{NI}$ & 6,0 & $\mathrm{NI}$ & $\mathrm{NI}$ \\
\hline 294 & 359 & AV. N.S. DO SABARA, 5312 & Servico de utilidade & $\mathrm{NI}$ & 7377870 & 329000 & 723 & $31 / 01 / 1997$ & cristalino & 122 & 6,2 & 4 & 42 & 6,0 & $\mathrm{NI}$ & $\mathrm{NI}$ \\
\hline 295 & 360 & AV. N.S. DO SABARA, 5312 & Servico de utilidade & $\mathrm{NI}$ & 7377920 & 328850 & 723 & $31 / 01 / 1997$ & nao confiavel & 173 & 5,1 & 9 & 82 & 5,1 & $\mathrm{NI}$ & $\mathrm{NI}$ \\
\hline 296 & 361 & AV. N. S. DO SABARA, 5312 & Servico de utilidade & $\begin{array}{l}\text { Jundsondas } \\
\end{array}$ & 7378500 & 329200 & 750 & $20 / 07 / 1996$ & cristalino & 200 & 5,9 & 17 & 139 & 5,9 & $\mathrm{NI}$ & 20 \\
\hline 297 & 362 & AV. N. S. DO SABARA, 5313 & Servico de utilidade & Hidrogesp & 7378300 & 328700 & 723 & $29 / 10 / 1996$ & cristalino & 140 & 6,4 & 5 & 118 & 6,4 & $\mathrm{NI}$ & $\mathrm{NI}$ \\
\hline 298 & 698 & R. PERICLES,376 & Extracao e comercio de agua & Corner & 7385570 & 328240 & 731 & $06 / 07 / 1976$ & sedimentar & 124 & 80,0 & 9 & 55 & 80,0 & 55 & 20 \\
\hline 299 & 699 & R. PERICLES, 376 & Extracao e comercio de agua & Outras & 7385670 & 328150 & 731 & $12 / 03 / 1991$ & nao confiavel & 145 & 6,0 & 40 & 75 & 6,0 & 75 & 20 \\
\hline 300 & 700 & R. PERICLES, 376 & Extracao e comercio de agua & Aguabras & 7385630 & 328270 & 731 & $25 / 03 / 1995$ & sedimentar & 133 & 29,3 & 8 & 95 & 29,3 & 87 & 20 \\
\hline 301 & 808 & R. PERICLES, 376 & Extracao e comercio de agua & $\begin{array}{l}\text { Jundsondas } \\
\end{array}$ & 7385680 & 328230 & 731 & $05 / 02 / 2001$ & nao confiavel & 150 & 30,0 & 15 & 98 & 30,0 & 98 & 20 \\
\hline 302 & $\mathrm{NI}$ & AV. WASHINGTON LUIZ, S/N & Servicos & $\mathrm{NI}$ & 7386100 & 330630 & $\mathrm{NI}$ & $16 / 08 / 2003$ & nao confiavel & $\mathrm{NI}$ & \begin{tabular}{|l|l|}
$\mathrm{NI}$ \\
\end{tabular} & $\mathrm{NI}$ & $\mathrm{NI}$ & 20,0 & $\mathrm{NI}$ & 20 \\
\hline 303 & $\mathrm{NI}$ & AV. WASHINGTON LUIZ, S/N & Servicos & $\mathrm{NI}$ & 7386050 & 330590 & $\mathrm{NI}$ & $05 / 06 / 2001$ & nao confiavel & $\mathrm{NI}$ & $\mathrm{NI}$ & $\mathrm{NI}$ & $\mathrm{NI}$ & 15,0 & $\mathrm{NI}$ & 20 \\
\hline 304 & 56 & R. DO NIQUEL, 170 & Extracao e comercio de agua & Corner & 7385890 & 328210 & 740 & $23 / 06 / 1988$ & misto 3 & 152 & 2100,0 & 31 & 42 & $\mathrm{NI}$ & $\mathrm{NI}$ & $\mathrm{NI}$ \\
\hline 305 & 57 & R. DA PRATA, 276 /AV. VICENTE RAO,621 & Extracao e comercio de agua & $\mathrm{NI}$ & 7385740 & 328250 & 733 & $17 / 12 / 1986$ & misto 1 & 138 & 720,0 & 27 & 42 & $\mathrm{NI}$ & $\mathrm{NI}$ & 6 \\
\hline 306 & 414 & R. DO NIQUEL, 170 & Extracao e comercio de agua & $\mathrm{NI}$ & 7385830 & 328250 & 735 & $15 / 06 / 1998$ & nao confiavel & 234 & 30,0 & 122 & 185 & 30,0 & 185 & 20 \\
\hline 307 & $\mathrm{NI}$ & R. DO NIQUEL, 170 & Extracao e comercio de agua & $\mathrm{NI}$ & 7385840 & 328190 & $\mathrm{NI}$ & NI & nao confiavel & $\mathrm{NI}$ & $\mathrm{NI}$ & $\mathrm{NI}$ & $\mathrm{NI}$ & $\mathrm{NI}$ & $\mathrm{NI}$ & $\mathrm{NI}$ \\
\hline 308 & $\mathrm{NI}$ & R. ARNALDO MAGNICARRO, 364 & Mecanica & $\mathrm{NI}$ & 7380697 & 327255 & $\mathrm{NI}$ & $\mathrm{NI}$ & $\mathrm{NI}$ & $\mathrm{NI}$ & $\mathrm{NI}$ & $\mathrm{NI}$ & $\mathrm{NI}$ & $\mathrm{NI}$ & $\mathrm{NI}$ & $\mathrm{NI}$ \\
\hline 309 & $\mathrm{NI}$ & AV. SANTO AMARO, 5355 & Clubes e similares & $\mathrm{NI}$ & $\mathrm{NI}$ & $\mathrm{NI}$ & $\mathrm{NI}$ & $\mathrm{NI}$ & nao confiavel & $\mathrm{NI}$ & $\mathrm{NI}$ & $\mathrm{NI}$ & $\mathrm{NI}$ & $\mathrm{NI}$ & $\mathrm{NI}$ & $\mathrm{NI}$ \\
\hline 310 & $\mathrm{NI}$ & AV. SANTO AMARO, 1239 & Educacao & $\mathrm{NI}$ & 7389650 & 329375 & $\mathrm{NI}$ & $\mathrm{NI}$ & $\mathrm{NI}$ & $\mathrm{NI}$ & $\mathrm{NI}$ & $\mathrm{NI}$ & $\mathrm{NI}$ & $\mathrm{NI}$ & $\mathrm{NI}$ & $\mathrm{NI}$ \\
\hline 311 & 121 & R. BRAGANCA PAULISTA, 867 & Metalurgica & Aguabras & 7384290 & 324690 & 727 & $08 / 02 / 1973$ & cristalino & 130 & 260,0 & 8 & 30 & $\mathrm{NI}$ & $\mathrm{NI}$ & $\mathrm{NI}$ \\
\hline 312 & 744 & AV. GUARAPIRANGA, 2400 & Eletro-eletronica & $\mathrm{NI}$ & 7379840 & 322440 & 775 & $\mathrm{NI}$ & nao confiavel & 153 & 6,0 & 54 & 105 & 6,0 & 105 & 8 \\
\hline 313 & 243 & R. MISSIONARIOS , 641 & Servicos (loja) & Corner & 7384610 & 324830 & 727 & $15 / 06 / 1972$ & cristalino & 166 & 5,8 & 19 & 75 & $\mathrm{NI}$ & $\mathrm{NI}$ & $\mathrm{NI}$ \\
\hline 314 & 91 & R. JOAQUIM NUNES TEIXEIRA, 158 & Metalurgica & Air Lift & 7384540 & 322610 & 738 & $12 / 12 / 1986$ & cristalino & 226 & 75,0 & 18 & 75 & $\mathrm{NI}$ & $\mathrm{NI}$ & $\mathrm{NI}$ \\
\hline 315 & $\mathrm{NI}$ & $\mathrm{NI}$ & Papel e celulose & $\mathrm{NI}$ & $\mathrm{NI}$ & $\mathrm{NI}$ & $\mathrm{NI}$ & $\mathrm{NI}$ & $\mathrm{NI}$ & $\mathrm{NI}$ & $\mathrm{NI}$ & $\mathrm{NI}$ & $\mathrm{NI}$ & $\mathrm{NI}$ & $\mathrm{NI}$ & $\mathrm{NI}$ \\
\hline
\end{tabular}




\begin{tabular}{|c|c|c|c|c|c|c|c|c|c|c|c|c|c|c|c|c|}
\hline \multicolumn{17}{|c|}{ ANEXO - CADASTRO DE POÇOS - Continuação } \\
\hline \begin{tabular}{|l} 
No.-de- \\
poços
\end{tabular} & $\begin{array}{l}\text { Poco_ } \\
\text { DAEEE }\end{array}$ & Endereco & Atividade & Cia_Perfuradora & N & E & $\mid \operatorname{cota}(\mathrm{m})$ & Data_Const & Aquifero & Prof-(m) & \begin{tabular}{|l|} 
Teste- \\
Vazao- \\
(m3/h)
\end{tabular} & \begin{tabular}{|l|} 
TesteN \\
$\mathrm{E}(\mathrm{m})$
\end{tabular} & \begin{tabular}{|l|} 
TesteN \\
$\mathrm{D}(\mathrm{m})$
\end{tabular} & \begin{tabular}{|l|} 
Vazao- \\
Explor- \\
(m3/h)
\end{tabular} & \begin{tabular}{|l} 
ND- \\
explor- \\
(m)
\end{tabular} & $\begin{array}{l}\text { Horas- } \\
\text { Exp }\end{array}$ \\
\hline 316 & 111 & \begin{tabular}{|l|} 
AV. NACOES UNIDAS, 20177 \\
\end{tabular} & Textil & $\mathrm{NI}$ & 7382160 & 325550 & 725 & \begin{tabular}{|l|}
$\mathrm{NI}$ \\
\end{tabular} & cristalino & 230 & $\mathrm{NI}$ & 22 & 53 & $\mathrm{NI}$ & $\mathrm{NI}$ & $\mathrm{NI}$ \\
\hline 317 & 112 & AV. DAS NACOES UNIDAS, 20177 & Textil & Corner & 7382260 & 325750 & 725 & $10 / 08 / 1988$ & misto 2 & 211 & 5,4 & 1 & 161 & $\mathrm{NI}$ & $\mathrm{NI}$ & $\mathrm{NI}$ \\
\hline 318 & $\mathrm{NI}$ & AV. DAS NACOES UNIDAS, 20177 & Textil & $\mathrm{NI}$ & 7382290 & 325540 & $\mathrm{NI}$ & $30 / 04 / 2001$ & nao confiavel & $\mathrm{NI}$ & $\mathrm{NI}$ & $\mathrm{NI}$ & $\mathrm{NI}$ & 1,5 & $\mathrm{NI}$ & 20 \\
\hline 319 & 1025 & AV. SANTO.AMARO, 6824 & alimentacao e bebidas & Constrolli & 7384600 & 326760 & 755 & $25 / 11 / 1995$ & misto1 & 71 & 2,4 & 12 & 47 & 1,5 & 39 & 15 \\
\hline 320 & $\mathrm{NI}$ & AV. N. SRA DO SABARA, 2058 & Residencial & $\mathrm{NI}$ & 7381100 & 327900 & $\mathrm{NI}$ & $13 / 11 / 2004$ & nao confiavel & $\mathrm{NI}$ & $\mathrm{NI}$ & $\mathrm{NI}$ & $\mathrm{NI}$ & 6,0 & $\mathrm{NI}$ & 20 \\
\hline 321 & 355 & R. ITAPAIUNA, S/N & Educacao & $\mathrm{NI}$ & 7385470 & 323800 & 737 & $26 / 02 / 1997$ & nao confiavel & 139 & 56,6 & 1 & 45 & 12,0 & $\mathrm{NI}$ & 4 \\
\hline 322 & $\mathrm{NI}$ & R. ITAPAIUNA, $S / N$ & Educacao & $\mathrm{NI}$ & 7385250 & 323740 & $\mathrm{NI}$ & NI & nao confiavel & $\mathrm{NI}$ & $\mathrm{NI}$ & $\mathrm{NI}$ & $\mathrm{NI}$ & $\mathrm{NI}$ & $\mathrm{NI}$ & $\mathrm{NI}$ \\
\hline 323 & 1491 & AV. SARGENTO GERALDO SANTANA, 1164 & Extracao e comercio de agua & Coperbras & 7381900 & 328710 & 750 & $20 / 09 / 1995$ & cristalino & 122 & 4,3 & 2 & 70 & 4,3 & 70 & 20 \\
\hline 324 & $\mathrm{NI}$ & R. DAVI PIMENTEL, 745 & Residencial & $\mathrm{NI}$ & 7387240 & 324850 & $\mathrm{NI}$ & $24 / 07 / 2002$ & nao confiavel & $\mathrm{NI}$ & $\mathrm{NI}$ & $\mathrm{NI}$ & $\mathrm{NI}$ & $\mathrm{NI}$ & $\mathrm{NI}$ & $\mathrm{NI}$ \\
\hline 325 & 1393 & AV. GUARAPIRANGA, 1028 & Fabricação de cimento & $\mathrm{NI}$ & 7381617 & 324233 & 725 & $\mathrm{NI}$ & nao confiavel & 135 & 9,5 & 9 & 24 & 9,0 & 24 & 16 \\
\hline 326 & $\mathrm{NI}$ & AV. GUARAPIRANGA, 1028 & Fabricação de cimento & $\mathrm{NI}$ & 7380450 & 327110 & $\mathrm{NI}$ & $28 / 12 / 2004$ & cristalino & $\mathrm{NI}$ & $\mathrm{NI}$ & $\mathrm{NI}$ & $\mathrm{NI}$ & 5,0 & $\mathrm{NI}$ & 12 \\
\hline 327 & 1394 & R. DAS BAIADEIRAS, S/N LOTES $24 / 25$ & Fabricação de cimento & $\mathrm{NI}$ & 7380740 & 327100 & 726 & \begin{tabular}{|l|}
$\mathrm{NI}$ \\
\end{tabular} & nao confiavel & 135 & 6,9 & 45 & 84 & 5,0 & 84 & 16 \\
\hline 328 & 1416 & ESTRADA. DA RIVIIERA, 6895 & Residencial & Sondagua & 7377040 & 322630 & 792 & $30 / 01 / 2004$ & nao confiavel & 168 & $\mathrm{NI}$ & $\mathrm{NI}$ & $\mathrm{NI}$ & $\mathrm{NI}$ & $\mathrm{NI}$ & $\mathrm{NI}$ \\
\hline 329 & 370 & R. PIRATINGA, 125 & Residencial & Aguabras & 7383720 & 328170 & 796 & $09 / 12 / 1996$ & misto 3 & 180 & 7,2 & 57 & 71 & 7,2 & 71 & 3 \\
\hline 330 & 46 & AV. SANTO AMARO,5137 & Quimica & Corner & 7385960 & 327920 & 745 & $25 / 06 / 1961$ & misto 1 & 182 & $\mathrm{NI}$ & 6 & 38 & $\mathrm{NI}$ & $\mathrm{NI}$ & $\mathrm{NI}$ \\
\hline 331 & 1065 & AV. JOAOS DIAS, 2319 & Eletro-eletronica & $\mathrm{NI}$ & 7384010 & 324280 & 727 & $\mathrm{NI}$ & cristalino & 102 & 12,0 & 21 & 35 & 9,0 & 33 & 6 \\
\hline 332 & 493 & AV. JOAO DIAS & Fabricacao plastico & Geopesquisadora & 7383940 & 325040 & 731 & $23 / 10 / 1998$ & nao confiavel & 302 & 10,0 & 2 & 116 & 10,0 & 116 & 20 \\
\hline 333 & 174 & R. GIBRALTAR., 258 & Imobiliaria & $\mathrm{NI}$ & 7383770 & 325010 & 736 & $22 / 06 / 2005$ & $\mathrm{NI}$ & 120 & $\mathrm{NI}$ & 15 & $\mathrm{NI}$ & 2,0 & $\mathrm{NI}$ & 3 \\
\hline 334 & $\mathrm{NI}$ & R. DESEMBARGADOR. SYLOS CINTRA, 278 & Residencial & $\mathrm{NI}$ & 7385120 & 328330 & $\mathrm{NI}$ & $23 / 06 / 2005$ & nao confiavel & $\mathrm{NI}$ & $\mathrm{NI}$ & $\mathrm{NI}$ & $\mathrm{NI}$ & 3,0 & $\mathrm{NI}$ & 2 \\
\hline 335 & $\mathrm{NI}$ & R. EDWARD WESTON, 199 & Hoteis e similares & $\mathrm{NI}$ & 7387770 & 326950 & $\mathrm{NI}$ & $02 / 06 / 2001$ & nao confiavel & $\mathrm{NI}$ & $\mathrm{NI}$ & $\mathrm{NI}$ & $\mathrm{NI}$ & $\mathrm{NI}$ & $\mathrm{NI}$ & $\mathrm{NI}$ \\
\hline 336 & 1060 & R. MIGUEL YUNES, 503 & Fabricacao de cimento & Tringil & 7379430 & 327820 & 727 & \begin{tabular}{|l|l}
$\mathrm{NI}$ \\
\end{tabular} & cristalino & 144 & 40,0 & 8 & 80 & 40,0 & 80 & 4 \\
\hline 337 & 1611 & R. DAS PEROBAS, 344 & Hospital & supersondas & 73844 & 33247 & $\mathrm{NI}$ & $31 / 03 / 2006$ & cristalino & 300 & 7,2 & 93 & 281 & 7,2 & 281 & 20 \\
\hline 338 & 61 & AV. SANTO AMARO, 6823 & Hospital & $\mathrm{NI}$ & 7384510 & 326850 & 762 & $04 / 07 / 1992$ & cristalino & 313 & 826,6 & 54 & 78 & $\mathrm{NI}$ & $\mathrm{NI}$ & $\mathrm{NI}$ \\
\hline 339 & $\mathrm{NI}$ & R. BARONESA DE BELA VISTA , 112 & Hoteis e similares & $\mathrm{NI}$ & 7386380 & 330420 & $\mathrm{NI}$ & $05 / 11 / 2002$ & nao confiavel & $\mathrm{NI}$ & $\mathrm{NI}$ & $\mathrm{NI}$ & $\mathrm{NI}$ & 18,0 & $\mathrm{NI}$ & 4 \\
\hline 340 & $\mathrm{NI}$ & AV. YERVANT KISSAIIIIAN, 1044 & Residencial & $\mathrm{NI}$ & 7381240 & 329730 & $\mathrm{NI}$ & $05 / 05 / 2005$ & nao confiavel & $\mathrm{NI}$ & $\mathrm{NI}$ & $\mathrm{NI}$ & $\mathrm{NI}$ & 8,0 & $\mathrm{NI}$ & $\mathrm{NI}$ \\
\hline 341 & 253 & R. GALEANO DE CASTRO, 247 & Galvanoplastia & Hidrotecnica & 7381900 & 326100 & 727 & $\mathrm{NI}$ & misto2 & 184 & 8,3 & 5 & 110 & $\mathrm{NI}$ & $\mathrm{NI}$ & $\mathrm{NI}$ \\
\hline 342 & 268 & R. CRISANTALINO ROLIM FREITAS,291 & Galvanoplastia & Corner & 7381850 & 326030 & 727 & $\mathrm{NI}$ & nao confiavel & 0 & 7,2 & 5 & 160 & 7,2 & $\mathrm{NI}$ & 20 \\
\hline 343 & $\mathrm{NI}$ & R. CRISTALINO ROLIM DE FREITAS, 291 & Galvanoplastia & $\mathrm{NI}$ & 7381810 & 326150 & $\mathrm{NI}$ & $20 / 10 / 2001$ & nao confiavel & $\mathrm{NI}$ & $\mathrm{NI}$ & $\mathrm{NI}$ & $\mathrm{NI}$ & $\mathrm{NI}$ & $\mathrm{NI}$ & $\mathrm{NI}$ \\
\hline 344 & $\mathrm{NI}$ & AV. JOAO DIAS, 1800 & \begin{tabular}{|l|l} 
Religiosa \\
\end{tabular} & $\mathrm{NI}$ & 7384160 & 324830 & $\mathrm{NI}$ & NI & nao confiavel & $\mathrm{NI}$ & $\mathrm{NI}$ & $\mathrm{NI}$ & $\mathrm{NI}$ & $\mathrm{NI}$ & $\mathrm{NI}$ & $\mathrm{NI}$ \\
\hline 345 & $\mathrm{NI}$ & AV. ROQUE PETRONI JUNIOR, 1391 & Shopping & $\mathrm{NI}$ & 7386730 & 326570 & $\mathrm{NI}$ & $20 / 09 / 1995$ & nao confiavel & $\mathrm{NI}$ & $\mathrm{NI}$ & $\mathrm{NI}$ & $\mathrm{NI}$ & 13,0 & $\mathrm{NI}$ & 20 \\
\hline 346 & 159 & AV. ROQUE PETRONI JUNIOR, 1391 & Shopping & $\mathrm{NI}$ & 7386310 & 326560 & 724 & $23 / 11 / 1994$ & cristalino & 0 & 12,9 & 31 & $\mathrm{NI}$ & $\mathrm{NI}$ & $\mathrm{NI}$ & $\mathrm{NI}$ \\
\hline 347 & 196 & AV. VICENTE RAO, 1001 & Posto de Servicos & Geoplan & 7385650 & 328600 & 735 & $27 / 02 / 1995$ & sedimentar & 109 & 7,2 & 50 & 54 & 7,2 & 54 & 18 \\
\hline 348 & 116 & ESTRADA. DO M'BOI MIRIM, 130 & $\mathrm{NI}$ & \begin{tabular}{|l} 
Jundsondas \\
\end{tabular} & 7381390 & 323100 & 745 & $26 / 09 / 1989$ & nao confiavel & 96 & 5,0 & 2 & 40 & $\mathrm{NI}$ & $\mathrm{NI}$ & $\mathrm{NI}$ \\
\hline 349 & 78 & R. BARAO DO TRIUNFO, 142 & Fabricacao alimentícios & \begin{tabular}{|l|} 
Corner \\
\end{tabular} & 7386760 & 328160 & 735 & $10 / 06 / 1964$ & misto 3 & 203 & 45,0 & 27 & 34 & $\mathrm{NI}$ & $\mathrm{NI}$ & $\mathrm{NI}$ \\
\hline 350 & 79 & R. BARAO DO TRIUNFO, 142 & Fabricacao alimentícios & Corner & 7386200 & 328230 & 745 & $16 / 10 / 1974$ & misto 3 & 150 & 90,0 & 35 & 40 & $\mathrm{NI}$ & $\mathrm{NI}$ & $\mathrm{NI}$ \\
\hline 351 & 80 & R. BARAO DO TRIUNFO, 142 & Fabricacao alimentícios & Corner & 7386150 & 328150 & 743 & $30 / 09 / 1988$ & misto 3 & 180 & 44,0 & 46 & 85 & $\mathrm{NI}$ & $\mathrm{NI}$ & $\mathrm{NI}$ \\
\hline 352 & 82 & R. BARAO DO TRIUNFO, 142 & Fabricacao alimentícios & Corner & 7386030 & 328130 & 740 & 09/03/1993 & misto 3 & 0 & $\mathrm{NI}$ & $\mathrm{NI}$ & $\mathrm{NI}$ & $\mathrm{NI}$ & $\mathrm{NI}$ & $\mathrm{NI}$ \\
\hline 353 & 18 & R. SANTO ARCADIO, 290/304 & Fabricação alimentícios & Air Lift & 7386530 & 327500 & 733 & $06 / 01 / 1973$ & cristalino & 278 & 14,4 & 77 & 120 & 14,4 & $\mathrm{NI}$ & 20 \\
\hline 354 & 19 & R. SANTO ARCADIO, 290/304 & Fabricação alimentícios & Pedro Geller & 7386500 & 327300 & 732 & $21 / 05 / 1968$ & cristalino & 205 & 9,0 & 82 & 148 & 9,0 & $\mathrm{NI}$ & 20 \\
\hline 355 & 778 & R. SANTO ARCADIO, 290/304 & Fabricação alimentícios & $\mathrm{NI}$ & 7386230 & 327440 & 727 & $\mathrm{NI}$ & nao confiavel & 230 & 8,0 & 85 & 115 & 4,0 & 115 & 24 \\
\hline 356 & $\mathrm{NI}$ & $\mathrm{NI} 2 \mathrm{sen}$ & $\mathrm{NI}$ & $\mathrm{NI}$ & 7301020 & 320020 & $\mathrm{NI}$ & $\mathrm{NI}$ & $\mathrm{NI}$ & $\mathrm{NI}$ & $\mathrm{NI}$ & $\mathrm{NI}$ & $\mathrm{NI}$ & $\mathrm{NI}$ & $\mathrm{NI}$ & $\mathrm{NI}$ \\
\hline 357 & 314 & R. FRANCISCO DIAS VELHO, 177 & Educacao & Jundsondas & 7386730 & 328100 & 736 & $05 / 03 / 1996$ & nao confiavel & 132 & 9,0 & 18 & 68 & 6,0 & 68 & 5 \\
\hline 358 & 1980 & AV. SARGENTO GERALDO SANTANA, 901 & Religiosa & Constrolli & 7381780 & 328210 & $\mathrm{NI}$ & $01 / 06 / 2004$ & cristalino & 252 & 1,2 & 55 & 156 & 1,2 & 156 & 20 \\
\hline 359 & 1981 & AV. GIOVANNI GRONCHI, 6899 & Eletro eletronica & General Water S/A & 738463 & 32297 & $\mathrm{NI}$ & $17 / 11 / 2006$ & cristalino & 285 & 15,5 & 46 & 77 & 10,0 & 66 & 18 \\
\hline 360 & $\mathrm{NI}$ & R. CORONELL LUIZ BARROSO, S/N & Educacao & $\mathrm{NI}$ & 7383800 & 326050 & $\mathrm{NI}$ & $05 / 05 / 2005$ & nao confiavel & $\mathrm{NI}$ & $\mathrm{NI}$ & $\mathrm{NI}$ & $\mathrm{NI}$ & $\mathrm{NI}$ & $\mathrm{NI}$ & $\mathrm{NI}$ \\
\hline
\end{tabular}




\begin{tabular}{|c|c|c|c|c|c|c|c|c|c|c|c|c|c|c|c|c|}
\hline \multicolumn{17}{|c|}{ ANEXO - CADASTRO DE POÇOS - Continuação } \\
\hline \begin{tabular}{|l} 
No.-de- \\
poços
\end{tabular} & $\begin{array}{l}\text { Poco_ } \\
\text { DAEEE }\end{array}$ & Endereco & Atividade & Cia_Perfuradora & $\mathbf{N}$ & E & Cota $(\mathrm{m}) \mid$ & Data_Const & Aquifero & Prof-(m) & \begin{tabular}{|l|} 
Teste- \\
Vazao- \\
(m3/h)
\end{tabular} & \begin{tabular}{|l|} 
TesteN \\
$\mathrm{E}(\mathrm{m})$
\end{tabular} & \begin{tabular}{|l|} 
TesteN \\
$\mathrm{D}(\mathrm{m})$
\end{tabular} & \begin{tabular}{|l|} 
Vazao- \\
Explor- \\
(m3/h)
\end{tabular} & \begin{tabular}{|l} 
ND- \\
explor- \\
(m)
\end{tabular} & $\begin{array}{l}\text { Horas- } \\
\text { Exp }\end{array}$ \\
\hline 361 & $\mathrm{NI}$ & R. CORONEL LUIZ BARROSO, S/N & Educacao & $\mathrm{NI}$ & 7381230 & 325550 & $\mathrm{NI}$ & $\mathrm{NI}$ & $\mathrm{NI}$ & $\mathrm{NI}$ & $\mathrm{NI}$ & $\mathrm{NI}$ & $\mathrm{NI}$ & $\mathrm{NI}$ & $\mathrm{NI}$ & $\mathrm{NI}$ \\
\hline 362 & 1036 & AV. INTERLAGOS, 2255 - INTERLAGOS & Imobiliaria & Geoplan & 7380770 & 328900 & 775 & $27 / 03 / 2001$ & cristalino & 178 & 33,2 & 58 & 114 & 23,2 & 105 & 15 \\
\hline 363 & 1037 & AV. INTERLAGOS, 2255 & Imobiliaria & Geoplan & 7380530 & 328980 & 764 & $05 / 04 / 2001$ & cristalino & 204 & $\mathrm{NI}$ & $\mathrm{NI}$ & $\mathrm{NI}$ & 3,0 & $\mathrm{NI}$ & $\mathrm{NI}$ \\
\hline 364 & 848 & R. JOAQUIM NUNES TEIXEIRA, 86 & Metalurgica & $\mathrm{NI}$ & 7384780 & 322550 & 740 & $\mathrm{NI}$ & cristalino & 201 & 6,0 & 7 & 65 & 6,0 & 65 & 20 \\
\hline 365 & 137 & R. MIGUEL DE VITTO, 325 & Metalurgica & $\mathrm{NI}$ & 7381020 & 328020 & 750 & $18 / 07 / 1990$ & $\mathrm{NI}$ & 79 & 100,0 & 10 & 65 & $\mathrm{NI}$ & $\mathrm{NI}$ & $\mathrm{NI}$ \\
\hline 366 & $\mathrm{NI}$ & AV. MIRUNA, 633 & Servicos (loja) & $\mathrm{NI}$ & 7387740 & 330220 & $\mathrm{NI}$ & $\mathrm{NI}$ & nao confiavel & $\mathrm{NI}$ & $\mathrm{NI}$ & $\mathrm{NI}$ & $\mathrm{NI}$ & $\mathrm{NI}$ & $\mathrm{NI}$ & $\mathrm{NI}$ \\
\hline 367 & 471 & AV. GUARAPIRANGA, 1389 & Metalurgica e plastica & Saiagua & 7381520 & 324080 & 726 & $\mathrm{NI}$ & nao confiavel & 170 & 11,8 & 13 & 21 & 12,0 & 25 & 20 \\
\hline 368 & $\mathrm{NI}$ & R. MARILA DE DIRCEU, 515 & Residencial & $\mathrm{NI}$ & 7385180 & 329970 & $\mathrm{NI}$ & $22 / 12 / 2001$ & nao confiavel & $\mathrm{NI}$ & $\mathrm{NI}$ & $\mathrm{NI}$ & $\mathrm{NI}$ & $\mathrm{NI}$ & $\mathrm{NI}$ & $\mathrm{NI}$ \\
\hline 369 & $\mathrm{NI}$ & $\mathrm{NI}$ & Residencial & $\mathrm{NI}$ & 7384030 & 327130 & $\mathrm{NI}$ & $\mathrm{NI}$ & $\mathrm{NI}$ & $\mathrm{NI}$ & $\mathrm{NI}$ & $\mathrm{NI}$ & $\mathrm{NI}$ & $\mathrm{NI}$ & $\mathrm{NI}$ & $\mathrm{NI}$ \\
\hline 370 & 1222 & R. TRINTA DE OUTUBRO, 15 & Extracao e comercio de agua & Outras & 7380250 & 326170 & 727 & $01 / 08 / 2001$ & cristalino & 250 & 20,0 & 40 & 170 & 20,0 & 170 & 20 \\
\hline 371 & $\mathrm{NI}$ & R. ANTONIO CAMPOS, 883 & $\mathrm{NI}$ & $\mathrm{NI}$ & 7379100 & 329680 & $\mathrm{NI}$ & $\mathrm{NI}$ & nao confiavel & $\mathrm{NI}$ & $\mathrm{NI}$ & $\mathrm{NI}$ & $\mathrm{NI}$ & $\mathrm{NI}$ & $\mathrm{NI}$ & $\mathrm{NI}$ \\
\hline 372 & 1324 & R. DR. MANOEL DIAS DE TOLESO, 53 & Residencial & Saiagua & 7380360 & 320480 & 800 & $14 / 11 / 2002$ & nao confiavel & 100 & 2,3 & 19 & 75 & 2,3 & 75 & 1 \\
\hline 373 & $\mathrm{NI}$ & R. ITALEGRE, 1233 (COND. VITORIA REGIA) & Residencial & $\mathrm{NI}$ & 7386970 & 324590 & $\mid \mathrm{NI}$ & $14 / 09 / 2002$ & nao confiavel & $\mathrm{NI}$ & $\mathrm{NI}$ & $\mathrm{NI}$ & $\mathrm{NI}$ & $\mathrm{NI}$ & $\mathrm{NI}$ & $\mathrm{NI}$ \\
\hline 374 & 1190 & R. MARIO LOPES LEAO, 1097 & \begin{tabular}{|l} 
Lavanderia \\
\end{tabular} & Hidroway & 7383260 & 324960 & 727 & NI & cristalino & 102 & 24,0 & 13 & 57 & 24,0 & 57 & 20 \\
\hline 375 & 281 & R. AUGUSTO FERREIRA DE MORAES, 602 & Fabricação alimentíicios & $\mathrm{NI}$ & 7381460 & 324950 & 726 & $02 / 03 / 1996$ & cristalino & 300 & 8,5 & 24 & 155 & 4,5 & $\mathrm{NI}$ & 20 \\
\hline 376 & 100 & R. ESTEVAM FURQUIM & $\mathrm{NI}$ & $\mathrm{NI}$ & 7387510 & 320480 & 745 & $\mathrm{NI}$ & nao confiavel & 170 & 20,0 & 14 & 72 & 20,0 & 72 & 20 \\
\hline 377 & 1646 & R. DR. EUCLIDES DA CUNHA, 339 & Extracao e comercio de agua & Consult. & 7380940 & 325280 & 736 & $01 / 01 / 2004$ & cristalino & 187 & 30,0 & 42 & 136 & 30,0 & 136 & 10 \\
\hline 378 & $\mathrm{NI}$ & R. GALENO DE CASTRO, 113 & Lavanderia & $\mathrm{NI}$ & 7381170 & 326060 & $\mathrm{NI}$ & $21 / 02 / 2004$ & nao confiavel & $\mathrm{NI}$ & $\mathrm{NI}$ & $\mathrm{NI}$ & $\mathrm{NI}$ & 2,6 & $\mathrm{NI}$ & 10 \\
\hline 379 & $\mathrm{NI}$ & AV. MARTA COELHO AGUIAR, 573 - LOJA 3 & Lavanderia & $\mathrm{NI}$ & 7383380 & 323310 & $\mathrm{NI}$ & \begin{tabular}{|l|}
$\mathrm{NI}$ \\
\end{tabular} & nao confiavel & $\mathrm{NI}$ & $\mathrm{NI}$ & $\mathrm{NI}$ & $\mathrm{NI}$ & $\mathrm{NI}$ & $\mathrm{NI}$ & $\mathrm{NI}$ \\
\hline 380 & 504 & AV. CASA GRANDE, 2336 & $\mathrm{NI}$ & $\mathrm{NI}$ & 7378330 & 328050 & 747 & $\mathrm{NI}$ & nao confiavel & 290 & 3,5 & 140 & 182 & 3,5 & 182 & 4 \\
\hline 381 & $\mathrm{NI}$ & R. PIRAPETINGA, 35 & Residencial & $\mathrm{NI}$ & 7383780 & 328080 & 796 & $\mathrm{NI}$ & cristalino & 200 & 3,0 & 60 & $\mathrm{NI}$ & $\mathrm{NI}$ & $\mathrm{NI}$ & $\mathrm{NI}$ \\
\hline 382 & 574 & AV. DUQUESA DE GOIAS, 430 & Imobiliaria & Geoplan & 7387740 & 326230 & 735 & $21 / 04 / 1998$ & cristalino & 162 & 2,0 & 5 & 153 & 2,0 & 153 & 20 \\
\hline 383 & 30 & R. BRASILIO LUZ 535 & Metalurgica & Geopesquisadora & 7382210 & 325630 & 724 & $21 / 09 / 1977$ & $\mathrm{NI}$ & 260 & 11,5 & 19 & 92 & 11,5 & 92 & 20 \\
\hline 384 & 31 & R. BRASILIO LUZ, 535 & Metalurgica & $\mathrm{NI}$ & 7382390 & 325530 & 724 & $\mathrm{NI}$ & cristalino & 130 & 1,5 & 7 & 40 & 1,5 & 40 & 20 \\
\hline 385 & 92 & R. JOAQUIM NUNES TEIXEIRA, 78 & Metalurgica & Air Lift & 7384440 & 322510 & 738 & $31 / 07 / 1973$ & nao confiavel & 311 & 16,8 & 5 & 69 & $\mathrm{NI}$ & $\mathrm{NI}$ & $\mathrm{NI}$ \\
\hline 386 & $\mathrm{NI}$ & R. ITATUPA, 209 & Residencial & $\mathrm{NI}$ & 7385590 & 323280 & $\mathrm{NI}$ & $\mathrm{NI}$ & nao confiavel & $\mathrm{NI}$ & $\mathrm{NI}$ & $\mathrm{NI}$ & $\mathrm{NI}$ & $\mathrm{NI}$ & $\mathrm{NI}$ & $\mathrm{NI}$ \\
\hline 387 & $\mathrm{NI}$ & R. JOAQUIM MORAIS, 483 & Residencial & $\mathrm{NI}$ & 7383370 & 330640 & $\mathrm{NI}$ & $31 / 07 / 2002$ & nao confiavel & $\mathrm{NI}$ & $\mathrm{NI}$ & $\mathrm{NI}$ & $\mathrm{NI}$ & $\mathrm{NI}$ & $\mathrm{NI}$ & $\mathrm{NI}$ \\
\hline 388 & 1603 & R. ADAMANTINA, 22 & Residencial & $\mathrm{NI}$ & 7383322 & 327790 & 797 & $\mathrm{NI}$ & sedimentar & 250 & 10,0 & 54 & 180 & 2,0 & 180 & 1 \\
\hline 389 & $\mathrm{NI}$ & $\mathrm{N1}$ & Fabricação alimentícios & $\mathrm{NI}$ & 7381230 & 325550 & $\mathrm{NI}$ & $\mathrm{NI}$ & $\mathrm{NI}$ & $\mathrm{NI}$ & $\mathrm{NI}$ & $\mathrm{NI}$ & $\mathrm{NI}$ & $\mathrm{NI}$ & $\mathrm{NI}$ & $\mathrm{NI}$ \\
\hline 390 & 1131 & R. BARAO DO RIO BRANCO, 555 & Planos de saude & $\mathrm{NI}$ & 7383470 & 325760 & 754 & $\mathrm{NI}$ & nao confiavel & 195 & 15,0 & $\mathrm{NI}$ & $\mathrm{NI}$ & 15,0 & 90 & 12 \\
\hline 391 & 1591 & R. AFRICA DO SUL, 160 & Metalurgica (pecas aco inox) & Aguabras Pocos & 7384324 & 324466 & 727 & $03 / 10 / 1988$ & cristalino & 102 & $\mathrm{NI}$ & $\mathrm{NI}$ & $\mathrm{NI}$ & $\mathrm{NI}$ & $\mathrm{NI}$ & $\mathrm{NI}$ \\
\hline 392 & 34 & AV. MARIA COELHO AGUIAR, 119 & empreendimentos imobiliarios & Air Lift & 7383750 & 323780 & 733 & $\mathrm{NI}$ & NI & 152 & 18,0 & 35 & 95 & $\mathrm{NI}$ & $\mathrm{NI}$ & $\mathrm{NI}$ \\
\hline 393 & 35 & AV. MARIA COELHO AGUIAR, 119 & empreendimentos imobiliarios & Air Lift & 7383970 & 323600 & 730 & $\mathrm{NI}$ & $\mathrm{NI}$ & 202 & $\mathrm{NI}$ & $\mathrm{NI}$ & $\mathrm{NI}$ & $\mathrm{NI}$ & $\mathrm{NI}$ & $\mathrm{NI}$ \\
\hline 394 & 36 & AV. MARIA COELHO AGUIAR, 119 & empreendimentos imobiliarios & Air Lift & 7383820 & 323540 & 733 & $10 / 08 / 1991$ & $\mathrm{NI}$ & 135 & 8,6 & 26 & 72 & $\mathrm{NI}$ & $\mathrm{NI}$ & $\mathrm{NI}$ \\
\hline 395 & 1436 & R. DEP. JOAO SUSSUMU HIRATA & Residencial & Saiagua & 7385890 & 323270 & 778 & $13 / 07 / 2004$ & cristalino & 180 & 0,7 & 39 & 133 & 0,7 & 133 & 10 \\
\hline 396 & $\mathrm{NI}$ & R. DEP. JOAO SUSSUMU HIRATA & \begin{tabular}{|l} 
Residencial \\
\end{tabular} & $\mathrm{NI}$ & 7385880 & 323250 & $\mathrm{NI}$ & $\mathrm{NI}$ & nao confiavel & $\mathrm{NI}$ & $\mathrm{NI}$ & $\mathrm{NI}$ & $\mathrm{NI}$ & $\mathrm{NI}$ & $\mathrm{NI}$ & $\mathrm{NI}$ \\
\hline 397 & 3 & ESTRADA. DO CAMPO LIMPO, 5794 & Extracao e comercio de agua & Rafael Faro Politi & 7387020 & 320690 & 740 & $25 / 03 / 1987$ & nao confiavel & 197 & 352,1 & 3 & 145 & $\mathrm{NI}$ & $\mathrm{NI}$ & $\mathrm{NI}$ \\
\hline 398 & 748 & R. SANTO ALBERTO, 221 & Religiosa & Jundsondas & 7381360 & 327910 & 755 & $25 / 07 / 2000$ & cristalino & 171 & 2,2 & 93 & 95 & 2,3 & 95 & 20 \\
\hline 399 & 1026 & \begin{tabular}{|l|} 
R. ITACOATIARA \\
\end{tabular} & Religiosa & \begin{tabular}{|l} 
Jundsondas \\
\end{tabular} & 7376300 & 326620 & 774 & $\mathrm{NI}$ & nao confiavel & 163 & 2,3 & 31 & 70 & 2,3 & 70 & 20 \\
\hline 400 & 910 & AV. DUQUESA DE GOIAS, 800 & Academia & \begin{tabular}{|l|} 
Hidrogeo \\
\end{tabular} & 7387510 & 326370 & 726 & $16 / 06 / 2000$ & cristalino & 218 & 5,6 & 8 & 42 & 15,0 & 95 & 10 \\
\hline 401 & $\mathrm{NI}$ & \begin{tabular}{|l|l|} 
R. JOAO ALFREDO, 503 \\
\end{tabular} & Fabrica de brinquedos & $\mathrm{NI}$ & 7382490 & 326280 & $\mathrm{NI}$ & NI & $\mathrm{NI}$ & $\mathrm{NI}$ & $\mathrm{NI}$ & $\frac{\mathrm{NI}}{\mathrm{NI}}$ & $\mathrm{NI}$ & $\mathrm{NI}$ & $\mathrm{NI}$ & $\mathrm{NI}$ \\
\hline 402 & $\mathrm{NI}$ & R. AURELIANO GUIMARAES, $S / N$ & Academia & $\mathrm{NI}$ & 7385740 & 322870 & $\mathrm{NI}$ & $31 / 03 / 2004$ & nao confiavel & $\mathrm{NI}$ & $\mathrm{NI}$ & $\mathrm{NI}$ & $\mathrm{NI}$ & 3,0 & $\mathrm{NI}$ & 5 \\
\hline 403 & $\mathrm{NI}$ & R. ARNALDO MAGNICARRO, 489 & Hoteis e similares & $\mathrm{NI}$ & 7380703 & 327264 & $\mathrm{NI}$ & $\mathrm{NI}$ & nao confiavel & $\mathrm{NI}$ & $\mathrm{NI}$ & $\mathrm{NI}$ & $\mathrm{NI}$ & $\mathrm{NI}$ & $\mathrm{NI}$ & $\mathrm{NI}$ \\
\hline 404 & $\mathrm{NI}$ & AV. MIRUNA , 680 & Servicos (loja de carros) & $\mathrm{NI}$ & 7387400 & 330540 & $\mathrm{NI}$ & $31 / 03 / 1999$ & nao confiavel & $\mathrm{NI}$ & $\mathrm{NI}$ & $\mathrm{NI}$ & $\mathrm{NI}$ & 5,0 & $\mathrm{NI}$ & 8 \\
\hline 405 & 311 & AV. DAS NACOES UNIDAS, 22002 & Metalurgica & Ceram. & 7380770 & 326590 & 724 & $10 / 07 / 1975$ & nao confiavel & 200 & 18,0 & 84 & 130 & 18,0 & 130 & 15 \\
\hline
\end{tabular}




\begin{tabular}{|c|c|c|c|c|c|c|c|c|c|c|c|c|c|c|c|c|}
\hline \multicolumn{17}{|c|}{ ANEXO - CADASTRO DE POÇOS - Continuação } \\
\hline $\begin{array}{l}\text { No.-de- } \\
\text { poços }\end{array}$ & $\begin{array}{l}\text { Poco_ } \\
\text { DAEEE }\end{array}$ & Endereco & Atividade & Cia_Perfuradora & $\mathbf{N}$ & E & Cota $(\mathrm{m})$ & Data_Const & Aquifero & Prof-(m) & \begin{tabular}{|l} 
Teste- \\
Vazao- \\
(m3/h)
\end{tabular} & $\mid$\begin{tabular}{|} 
TesteN \\
$\mathrm{E}(\mathrm{m})$
\end{tabular} & \begin{tabular}{|l|} 
Testen \\
$\mathrm{D}(\mathrm{m})$
\end{tabular} & \begin{tabular}{|l} 
Vazao- \\
Explor- \\
(m3/h)
\end{tabular} & \begin{tabular}{|l|} 
ND- \\
explor- \\
(m)
\end{tabular} & $\begin{array}{l}\text { Horas- } \\
\text { Exp }\end{array}$ \\
\hline 406 & 312 & AV. DAS NACOES UNIDAS, 22002 & Metalurgica & Geopesquisadora & 7380910 & 326480 & 724 & $01 / 10 / 1988$ & cristalino & 204 & 6,0 & 33 & 157 & 6,0 & 158 & 15 \\
\hline 407 & $\mathrm{NI}$ & R. PROFESSOR. JOSE HORACIO MEIRELLES & Servicos (oficina) & $\mathrm{NI}$ & 7387800 & 323080 & $\mathrm{NI}$ & $\mathrm{NI}$ & nao confiavel & $\mathrm{NI}$ & $\mathrm{NI}$ & $\mathrm{NI}$ & $\mathrm{NI}$ & $\mathrm{NI}$ & $\mathrm{NI}$ & $\mathrm{NI}$ \\
\hline 408 & 139 & R. ADA NEGRI, 505 & Shopping (posto de gasol.) & Air Lift & 7383610 & 325120 & 733 & $14 / 12 / 1989$ & cristalino & 150 & 3,0 & 30 & 71 & 3,0 & 71 & 20 \\
\hline 409 & $\mathrm{NI}$ & AV. DOS LAGOS, 382 & $\mathrm{NI}$ & $\mathrm{NI}$ & $\mathrm{NI}$ & $\mathrm{NI}$ & $\mathrm{NI}$ & $\mathrm{NI}$ & nao confiavel & $\mathrm{NI}$ & $\mathrm{NI}$ & $\mathrm{NI}$ & $\mathrm{NI}$ & $\mathrm{NI}$ & $\mathrm{NI}$ & $\mathrm{NI}$ \\
\hline 410 & $\mathrm{NI}$ & AV. DOS LAGOS, 396A & $\mathrm{NI}$ & $\mathrm{NI}$ & $\mathrm{NI}$ & $\mathrm{NI}$ & $\mid \mathrm{NI}$ & $\mathrm{NI}$ & |nao confiavel & $\mathrm{NI}$ & NI & $\mathrm{NI}$ & $\mathrm{NI}$ & $\mathrm{NI}_{\mathrm{NI}}$ & $\mid \mathrm{NI}$ & $\mathrm{NI}$ \\
\hline 411 & $\mathrm{NI}$ & AV. RIO BONITO, 694 & $\mathrm{NI}$ & $\mathrm{NI}$ & $\mathrm{NI}$ & $\mathrm{NI}$ & $\mathrm{NI}$ & $\mathrm{NI}$ & nao confiavel & $\mathrm{NI}$ & $\mathrm{NI}$ & $\mathrm{NI}$ & $\mathrm{NI}$ & $\mathrm{NI}$ & $\mathrm{NI}$ & $\mathrm{NI}$ \\
\hline 412 & $\mathrm{NI}$ & R. MANOEL FIGUEIREDO LANDIM, 400 & $\mathrm{NI}$ & $\mathrm{NI}$ & $\mathrm{NI}$ & $\mathrm{NI}$ & $\mathrm{NI}$ & $\mathrm{NI}$ & nao confiavel & $\mathrm{NI}$ & $\mathrm{NI}$ & $\mathrm{NI}$ & $\mathrm{NI}$ & $\mathrm{NI}$ & $\mathrm{NI}$ & $\mathrm{NI}$ \\
\hline 413 & $\mathrm{NI}$ & R. PROF HAIDEE SILVA MARTINS, 176 & $\mathrm{NI}$ & $\mathrm{NI}$ & $\mathrm{NI}$ & $\mathrm{NI}$ & $\mathrm{NI}$ & $\mathrm{NI}$ & nao confiavel & $\mathrm{NI}$ & $\mathrm{NI}$ & $\mathrm{NI}$ & $\mathrm{NI}$ & $\mathrm{NI}$ & $\mathrm{NI}$ & $\mathrm{NI}$ \\
\hline 414 & $\mathrm{NI}$ & R. PEDRO MARI, 80 & Quimica (cosmetico) & $\mathrm{NI}$ & 7386320 & 320260 & $\mathrm{NI}$ & $\mathrm{NI}$ & nao confiavel & $\mathrm{NI}$ & $\mathrm{NI}$ & $\mathrm{NI}$ & $\mathrm{NI}$ & $\mathrm{NI}$ & $\mathrm{NI}$ & $\mathrm{NI}$ \\
\hline 415 & $\mathrm{NI}$ & R. ALEXANDRE GUSMAO 94 & Eletronica & $\mathrm{NI}$ & 7381870 & 325390 & 725 & $\mathrm{NI}$ & $\mathrm{NI}$ & $\mathrm{NI}$ & $\mathrm{NI}$ & $\mathrm{NI}$ & $\mathrm{NI}$ & $\mathrm{NI}$ & $\mathrm{NI}$ & $\mathrm{NI}$ \\
\hline 416 & $\mathrm{NI}$ & R. DOS CHAVES, 571 & alimentacao e bebidas & $\mathrm{NI}$ & 7387390 & 330130 & $\mathrm{NI}$ & $\mathrm{NI}$ & nao confiavel & $\mathrm{NI}$ & $\mathrm{NI}$ & $\mathrm{NI}$ & $\mathrm{NI}$ & $\mathrm{NI}$ & $\mathrm{NI}$ & $\mathrm{NI}$ \\
\hline 417 & $\mathrm{NI}$ & R. NELSON GAMA DE OLIVEIRA, 439 & Cabelereiros & $\mathrm{NI}$ & 7385430 & 322900 & $\mathrm{NI}$ & $29 / 03 / 2000$ & nao confiavel & $\mathrm{NI}$ & $\mathrm{NI}$ & $\mathrm{NI}$ & $\mathrm{NI}$ & $\mathrm{NI}$ & $\mathrm{NI}$ & $\mathrm{NI}$ \\
\hline 418 & 691 & R. BENTO BRANCO ANDRADE FILHO, 621 & Eletro-eletronica & Jundsondas & 7383360 & 324570 & 724 & \begin{tabular}{|l|l}
$\mathrm{NI}$ \\
\end{tabular} & cristalino & 144 & 14,0 & 19 & 77 & 14,0 & 77 & 14 \\
\hline 419 & 692 & R. BENTO BRANCO DE ANDRADE FILHO,621 & Eletro-eletronica & Jundsondas & 7383370 & 324610 & 724 & $11 / 05 / 2000$ & cristalino & 200 & 14,1 & 12 & 93 & 14,0 & 93 & 16 \\
\hline 420 & 1556 & R. SAO BENEDITO, 2498 & Comercio varejista & Nascente & 7385303 & 327540 & 757 & $15 / 01 / 2005$ & cristalino & 357 & 5,0 & 170 & 220 & 3,0 & 220 & 3 \\
\hline 421 & 816 & R. ALEXANDRE DUMAS, 1711 -60 AND. & \begin{tabular}{|l|l|} 
Hoteis e similares \\
\end{tabular} & Hidromac & 7385290 & 324180 & 750 & $04 / 06 / 2000$ & nao confiavel & 180 & 9,4 & 5 & 149 & 9,0 & 149 & 13 \\
\hline 422 & $\mathrm{NI}$ & R. BARONESA DE BELA VISTA , 101 & \begin{tabular}{|l|l|} 
Hoteis e similares \\
\end{tabular} & $\mathrm{NI}$ & 7387030 & 330420 & $\mathrm{NI}$ & $19 / 01 / 2000$ & nao confiavel & $\mathrm{NI}$ & $\mathrm{NI}$ & $\mathrm{NI}$ & $\mathrm{NI}$ & 2,0 & $\mathrm{NI}$ & 20 \\
\hline 423 & $\mathrm{NI}$ & $\mathrm{NI}$ & alimentacao e bebidas & $\mathrm{NI}$ & 7392760 & 329900 & $\mathrm{NI}$ & $\mathrm{NI}$ & $\mathrm{NI}$ & $\mathrm{NI}$ & $\mathrm{NI}$ & $\mathrm{NI}$ & $\sqrt{\mathrm{NI}}$ & $\mathrm{NI}$ & $\mathrm{NI}$ & $\mathrm{NI}$ \\
\hline 424 & 512 & R. VIEIRA DE MORAIS, 1029 & Posto de Servicos & Rodagua & 7386690 & 329460 & 753 & $\mathrm{NI}$ & sedimentar & 47 & 2,0 & 6 & 20 & 2,0 & 20 & 20 \\
\hline 425 & 1422 & R. DEPUTADO LAERCIO CORTE, 1465 & empreendimentos imobiliarios & Garca Pocos & 7385304 & 324224 & 740 & $03 / 02 / 2004$ & cristalino & 300 & 9,0 & 27 & 188 & 3,0 & 188 & 1 \\
\hline 426 & $\mathrm{NI}$ & AV. ALFREDO EGIDIO ARANHA, 100 & $\mathrm{NI}$ & $\mathrm{NI}$ & 7385430 & 325400 & $\mathrm{NI}$ & $28 / 06 / 2001$ & nao confiavel & $\mathrm{NI}$ & $\mathrm{NI}$ & $\mathrm{NI}$ & $\mathrm{NI}$ & 5,0 & $\mathrm{NI}$ & 20 \\
\hline 427 & $\mathrm{NI}$ & R. IRINEU MARINHO , 555 & Residencial & $\mathrm{NI}$ & 7384030 & 327130 & $\mathrm{NI}$ & $02 / 06 / 2001$ & nao confiavel & $\mathrm{NI}$ & $\mathrm{NI}$ & $\mathrm{NI}$ & $\mathrm{NI}$ & $\mathrm{NI}$ & $\mathrm{NI}$ & $\mathrm{NI}$ \\
\hline 428 & 216 & R. ELIZABETA LIPS, 304 & $\mathrm{NI}$ & $\mathrm{NI}$ & 7387700 & 320490 & 745 & $13 / 09 / 2000$ & nao confiavel & 160 & 11,3 & 54 & 89 & 11,3 & 89 & 1 \\
\hline 429 & 1608 & R. AFRICA DO SUL, 288 & Extracao e comercio de agua & Lucksondas & 7384349 & 324350 & 726 & $\mathrm{NI}$ & cristalino & 145 & 11,2 & 20 & 55 & 11,2 & 55 & 20 \\
\hline 430 & $253 \_A$ & R. CESARIO DAY,156 & Atividades de saude & $\begin{array}{ll}\mathrm{NI} \\
\end{array}$ & 7387820 & 320390 & 760 & $20 / 03 / 2002$ & cristalino & 80 & 4,5 & 27 & 65 & 4,5 & 65 & 20 \\
\hline 431 & 1078 & AV. RIO BONITO, 1201 & Fabricacao de nao-refratarios & Corner & 7379960 & 326230 & 750 & $02 / 03 / 1980$ & cristalino & 250 & 2,0 & 95 & 165 & 2,0 & 165 & 24 \\
\hline 432 & 444 & R. VIEIRA DE MORAIS, 683 & Posto de Servicos & $\mathrm{NI}$ & 7386900 & 329190 & 752 & 01/04/1997 & sedimentar & 47 & 2,5 & 6 & 20 & 2,5 & 20 & 20 \\
\hline 433 & $\mathrm{NI}$ & PCA MIGUEL ORTEGA, 439 & Administracao publica & $\mathrm{NI}$ & 7386630 & 318720 & $\mathrm{NI}$ & $10 / 10 / 2000$ & nao confiavel & $\mathrm{NI}$ & $\mathrm{NI}$ & $\mathrm{NI}$ & $\mathrm{NI}$ & $\mathrm{NI}$ & $\mathrm{NI}$ & $\mathrm{NI}$ \\
\hline 434 & 1325 & R. LUIZ PRIETO ROQUE, 135 & Residencial & Outras & 7378350 & 326350 & 775 & NI & sedimentar & 15 & 0,6 & 7 & 12 & 0,6 & 12 & 3 \\
\hline 435 & 1275 & R. DOM AGUIRRE, 576 & eletro-eletronicos & $\mathrm{NI}$ & 7382390 & 327850 & 750 & $\mathrm{NI}$ & nao confiavel & 0 & 2,9 & 32 & 122 & 2,9 & 122 & 13 \\
\hline 436 & $\mathrm{NI}$ & AV. ENG. EUSEBIO STEVAUX, 124 & Fabricacao de gelo & $\mathrm{NI}$ & 7382060 & 326060 & 725 & $03 / 03 / 2000$ & cristalino & 132 & 16,4 & 10 & 82 & 15,0 & 18 & 3 \\
\hline 437 & 1224 & R. JOSE MARTINS COELHO, 300 & \begin{tabular}{|l|l} 
Metalurgica \\
\end{tabular} & Outras & 7378600 & 328510 & 730 & $\mathrm{NI}$ & cristalino & 112 & 44,0 & 5 & 32 & 30,0 & 23 & 2 \\
\hline 438 & 867 & \begin{tabular}{|l|} 
R. VERBO DIVINO,993-A \\
\end{tabular} & Educacao & Geoplan & 7385310 & 326030 & 733 & 08/07/2001 & nao confiavel & 130 & 24,0 & 13 & 32 & 7,5 & 15 & 8 \\
\hline 439 & 442 & R. DEMOSTENES, 748 & Hoteis e similares & $\mathrm{NI}$ & 7387150 & 329380 & 748 & 0 & sedimentar & 82 & 4,0 & 16 & 45 & 4,0 & 29 & 20 \\
\hline 440 & $\mathrm{NI}$ & R. ITABAPOANA, 150 & Residencial & $\mathrm{NI}$ & $\mathrm{NI}$ & $\mathrm{NI}$ & $\mathrm{NI}$ & $\mathrm{NI}$ & nao confiavel & $\mathrm{NI}$ & $\mathrm{NI}$ & $\mathrm{NI}$ & $\mathrm{NI}$ & $\mathrm{NI}$ & $\mathrm{NI}$ & $\mathrm{NI}$ \\
\hline 441 & 508 & AV. ROQUE PETRONI JR. 759 & Ensino de esportes & Hidroway & 7386290 & 327110 & 725 & $\mathrm{NI}$ & nao confiavel & 170 & 4,0 & 39 & 82 & 3,0 & 109 & 6 \\
\hline 442 & 1109 & R. DR. RUBENS GOMES BUENO, 478 & Metalurgica (autopecas) & $\mathrm{NI}$ & 7384450 & 324640 & 726 & $\mathrm{NI}$ & nao confiavel & 123 & 3,6 & 18 & 68 & 3,6 & 100 & 20 \\
\hline 443 & 1110 & R. DR. RUBENS GOMES BUENO, 478 & Metalurgica (autopecas) & $\mathrm{NI}$ & 7384440 & 324720 & 726 & $\mathrm{NI}$ & nao confiavel & 126 & $\mathrm{NI}$ & 19 & $\mathrm{NI}$ & $\mathrm{NI}$ & $\mathrm{NI}$ & $\mathrm{NI}$ \\
\hline 444 & 1111 & R. DR. RUBENS GOMES BUENO, 478 & Metalurgica (autopecas) & $\mathrm{NI}$ & 7384420 & 324560 & 726 & jan-81 & nao confiavel & 134 & 23,3 & 21 & 24 & 23,7 & 24 & 20 \\
\hline 445 & 1112 & R. DR. RUBENS GOMES BUENO, 478 & Metalurgica (autopecas) & \begin{tabular}{|l|l}
$\mathrm{NI}$ \\
\end{tabular} & 7384440 & 324690 & 726 & $\mathrm{NI}$ & nao confiavel & 163 & 23,3 & 22 & 25 & 23,3 & 26 & 20 \\
\hline 446 & 1664 & R. BENEDITO FERREIRA DA SILVA, 21 & Residencial & Jundsondas & 7378160 & 326150 & 777 & $03 / 02 / 2003$ & cristalino & 200 & 2,2 & 34 & 69 & 2,2 & 69 & 2 \\
\hline 447 & $\mathrm{NI}$ & AV. PROF ALCEU MAYNARD DE ARAUJO , 71 & Academia & $\mathrm{NI}$ & 7385140 & 324910 & $\mathrm{NI}$ & $11 / 04 / 2001$ & nao confiavel & $\mathrm{NI}$ & $\mathrm{NI}$ & $\mathrm{NI}$ & $\mathrm{NI}$ & $\mathrm{NI}$ & $\mathrm{NI}$ & $\mathrm{NI}$ \\
\hline 448 & 1580 & R. SAO JOAO ALFREDO, 177 & Minerais nao metalicos & T. Janer & 7382610 & 326710 & 740 & $12 / 12 / 1979$ & misto 3 & 150 & 12,1 & 9 & 64 & 12,1 & 64 & 8 \\
\hline 449 & 1581 & R. SAO JOAO ALFREDO, 177 & Minerais nao metalicos & T. Janer & 7382630 & 326670 & 737 & $\mathrm{NI}$ & nao confiavel & $\mathrm{NI}$ & 14,3 & 8 & 14 & 14,3 & 14 & 8 \\
\hline 450 & 1502 & AV. NACOES UNIDAS, 21732 & metalurgica & $\mathrm{NI}$ & 7380900 & 326210 & 723 & $24 / 02 / 2003$ & |cristalino & 200 & 4,5 & 93 & 181 & 4,5 & 181 & 14 \\
\hline
\end{tabular}




\begin{tabular}{|c|c|c|c|c|c|c|c|c|c|c|c|c|c|c|c|c|}
\hline \multicolumn{17}{|c|}{ ANEXO - CADASTRO DE POÇOS - Continuação } \\
\hline \begin{tabular}{|l} 
No.-de- \\
poços
\end{tabular} & $\begin{array}{l}\text { Poco_ } \\
\text { DAEEE }\end{array}$ & Endereco & Atividade & Cia_Perfuradora & $\mathbf{N}$ & E & Cota $(\mathrm{m}) \mid$ & Data_Const & Aquifero & Prof-(m) & \begin{tabular}{|l|} 
Teste- \\
Vazao- \\
(m3/h)
\end{tabular} & $\mid$\begin{tabular}{|} 
TesteN \\
$\mathrm{E}(\mathrm{m})$
\end{tabular} & \begin{tabular}{|l|} 
Testen \\
$\mathrm{D}(\mathrm{m})$
\end{tabular} & \begin{tabular}{|l|} 
Vazao- \\
Explor- \\
(m3/h)
\end{tabular} & \begin{tabular}{|l|} 
ND- \\
explor- \\
(m)
\end{tabular} & $\begin{array}{l}\text { Horas- } \\
\text { Exp }\end{array}$ \\
\hline 451 & 1503 & AV. NACOES UNIDAS, 21732 & metalurgica & $\mathrm{NI}$ & 7381020 & 326390 & 723 & $25 / 11 / 1997$ & cristalino & 258 & 7,5 & 84 & 205 & 7,5 & 205 & 5 \\
\hline 452 & 1501 & AV. NACOES UNIDAS, 21732 & metalurgica & $\mathrm{NI}$ & 7380980 & 326220 & 723 & $02 / 12 / 1970$ & cristalino & 150 & 11,1 & 92 & 100 & 11,1 & 100 & 3 \\
\hline 453 & $\mathrm{NI}$ & R. CANORI, 190 & Servicos (loja de mat const) & $\mathrm{NI}$ & 7385730 & 321050 & $\mathrm{NI}$ & $19 / 06 / 2001$ & nao confiavel & $\mathrm{NI}$ & $\mathrm{NI}$ & $\mathrm{NI}$ & $\mathrm{NI}$ & $\mathrm{NI}$ & $\mathrm{NI}$ & $\mathrm{NI}$ \\
\hline 454 & $\mathrm{NI}$ & AV. GIOVANNI GRONCHI, 3800 & alimentacao e bebidas & $\mathrm{NI}$ & 7387550 & 323470 & $\mathrm{NI}$ & $\mathrm{NI}$ & nao confiavel & $\mathrm{NI}$ & $\mathrm{NI}$ & $\mathrm{NI}$ & $\mathrm{NI}$ & $\mathrm{NI}$ & $\mathrm{NI}$ & $\mathrm{NI}$ \\
\hline 455 & 1323 & AV. NICOLAU ALAYON, 441 & Quimica-farmaceutica & Aguabras & 7377050 & 326140 & 781 & $\mathrm{NI}$ & |nao confiavel & 250 & 3,3 & 50 & 139 & 3,3 & 139 & 20 \\
\hline 456 & 167 & EST. DA CUMBICA, 475 - GUARAPIRANGA & Clubes e similares & $\mathrm{NI}$ & 7376030 & 320090 & 800 & 09/06/1997 & nao confiavel & 217 & 17,6 & 16 & 114 & 12,0 & 83 & 19 \\
\hline 457 & $\mathrm{NI}$ & PCA DOM FRANCISCO DE SOUSA, 540 & Clubes e similares & $\mathrm{NI}$ & $\mathrm{NI}$ & $\mathrm{NI}$ & $\mathrm{NI}$ & $\mathrm{NI}$ & nao confiavel & $\mathrm{NI}$ & NI & $\mathrm{NI}$ & $\mathrm{NI}$ & $\mathrm{NI}$ & $\mathrm{NI}$ & $\mathrm{NI}$ \\
\hline 458 & $\mathrm{NI}$ & PCA DOM FRANCISCO DE SOUZA, 540 & Clubes e similares & $\mathrm{NI}$ & 7382110 & 326495 & $\mathrm{NI}$ & $\mathrm{NI}$ & nao confiavel & $\mathrm{NI}$ & $\mathrm{NI}$ & $\mathrm{NI}$ & $\mathrm{NI}$ & $\mathrm{NI}$ & $\mathrm{NI}$ & $\mathrm{NI}$ \\
\hline 459 & 279 & R. MIGUEL MELLO, 55 & Clubes e similares & $\mathrm{NI}$ & 7383850 & 321280 & 743 & $\mathrm{NI}$ & cristalino & 78 & $\mathrm{NI}$ & $\mathrm{NI}$ & $\mathrm{NI}$ & $\mathrm{NI}$ & $\mathrm{NI}$ & $\mathrm{NI}$ \\
\hline 460 & 686 & R. DOM AGUIRRE,438 & Metalurgica & Jundsondas & 7382420 & 327970 & 745 & $05 / 01 / 1999$ & nao confiavel & 198 & 2,4 & 14 & 138 & 2,4 & 138 & 10 \\
\hline 461 & 168 & AV. ENG. EUSEBIO STEVAUX, 823 & Educacao & Corner & 7381260 & 326910 & 724 & $11 / 04 / 1969$ & misto 2 & 175 & $\mathrm{NI}$ & $\mathrm{NI}$ & $\mathrm{NI}$ & $\mathrm{NI}$ & $\mathrm{NI}$ & $\mathrm{NI}$ \\
\hline 462 & 1401 & AV. ENG. EUSEBIO STEVAUX, 823 & Educacao & $\mathrm{NI}$ & 7381450 & 326720 & 724 & $01 / 11 / 2003$ & misto 3 & 142 & 22,0 & 3 & 31 & 10,0 & 16 & 20 \\
\hline 463 & $\mathrm{NI}$ & R. SANTO ARCADIO, 92 & $\mathrm{NI}$ & $\mathrm{NI}$ & 7386600 & 327570 & $\mid \mathrm{NI}$ & $23 / 07 / 1997$ & nao confiavel & $\mathrm{NI}$ & $\mathrm{NI}$ & $\mathrm{NI}$ & $\mathrm{NI}$ & $\mathrm{NI}$ & $\mathrm{NI}$ & $\mathrm{NI}$ \\
\hline 464 & $\mathrm{NI}$ & R. ARMANDO ERSE FIGUEIREDO , S/N & Residencial & $\mathrm{NI}$ & 7385850 & 319500 & $\mathrm{NI}$ & $\mathrm{NI}$ & nao confiavel & $\mathrm{NI}$ & $\mathrm{NI}$ & $\mathrm{NI}$ & $\mathrm{NI}$ & $\mathrm{NI}$ & $\mathrm{NI}$ & $\mathrm{NI}$ \\
\hline 465 & 313 & AV. DAS NACOES UNIDAS, 18605 & empreendimentos imobiliarios & Jundsondas & 7382830 & 324760 & 724 & $10 / 02 / 1997$ & nao confiavel & 260 & 4,5 & 15 & 172 & 4,5 & 172 & 20 \\
\hline 466 & 212 & R. DR. RUBENS GOMES BUENO,509 & Quimica_agroquimicos & Rafael Faro Politi & 7384360 & 324520 & 726 & $\mathrm{NI}$ & misto 2 & 180 & 22,0 & 24 & 27 & 22,0 & $\mathrm{NI}$ & 20 \\
\hline 467 & 540 & R. DOS CAFEZAIS, 295 & Clubes e similares & Corner & 7383800 & 329600 & 740 & $\mathrm{NI}$ & sedimentar & 141 & 16,5 & 31 & 80 & 16,5 & 80 & 20 \\
\hline 468 & 541 & R. DOS CAFEZAIS, 461 & Clubes e similares & Corner & 7383630 & 329650 & 740 & $\mathrm{NI}$ & nao confiavel & 104 & 7,0 & 51 & 78 & 7,0 & 78 & 20 \\
\hline 469 & $\mathrm{NI}$ & AV. SARGENTO GERALDO SANTANA , 901 & Servico social & $\mathrm{NI}$ & 7381780 & 328210 & $\mathrm{NI}$ & $20 / 04 / 2004$ & nao confiavel & $\mathrm{NI}$ & $\mathrm{NI}$ & $\mathrm{NI}$ & $\mathrm{NI}$ & 1,5 & $\mathrm{NI}$ & 4 \\
\hline 470 & $\mathrm{NI}$ & $\mathrm{NI}$ & \begin{tabular}{|l|} 
Clubes e similares \\
\end{tabular} & $\mathrm{NI}$ & 7397340 & 325850 & $\mathrm{NI}$ & $\mathrm{NI}$ & $\mathrm{NI}$ & $\mathrm{NI}$ & $\mathrm{NI}$ & $\mathrm{NI}$ & $\mathrm{NI}$ & $\mathrm{NI}$ & $\mathrm{NI}$ & $\mathrm{NI}$ \\
\hline 471 & 908 & R. VITALINA GRASSMAN, 9-A & Fabricacao de cimento & Outras & 7383950 & 323000 & 760 & $\mathrm{NI}$ & misto2 & 120 & 5,0 & 23 & 75 & 5,0 & 75 & 11 \\
\hline 472 & 1345 & AV. GIOVANNI GRONCHI, 5830 & Comercio varejista & Corner & 7385480 & 322650 & 755 & $\mathrm{NI}$ & sedimentar & 75 & 5,0 & 10 & 70 & 5,0 & 70 & 12 \\
\hline 473 & $\mathrm{NI}$ & PRACA DOM FRANCISCO DE SOUZA, 126 & Comercio varejista & $\mathrm{NI}$ & 7382400 & 326000 & $\mathrm{NI}$ & $\mathrm{NI}$ & nao confiavel & $\mathrm{NI}$ & $\mathrm{NI}$ & $\mathrm{NI}$ & $\mathrm{NI}$ & $\mathrm{NI}$ & $\mathrm{NI}$ & $\mathrm{NI}$ \\
\hline 474 & $\mathrm{NI}$ & $\mathrm{NI}$ & Comercio varejista & $\mathrm{NI}$ & 7377050 & 326140 & $\mathrm{NI}$ & $\mathrm{NI}$ & $\mathrm{NI}$ & $\mathrm{NI}$ & $\mathrm{NI}$ & NI & $\mathrm{NI}$ & $\mathrm{NI}$ & $\mathrm{NI}$ & $\mathrm{NI}$ \\
\hline 475 & 303 & AV. ROQUE PETRONI, 850 & alimentacao e bebidas & $\mathrm{NI}$ & 7386380 & 327120 & 727 & $\mathrm{NI}$ & nao confiavel & 102 & 1,3 & 80 & 82 & 1,3 & 82 & 20 \\
\hline 476 & 1442 & R. DEP. LAERCIO CORTE, 1250 & Residencial & Hidroklockner & 7385340 & 324080 & 770 & $27 / 08 / 2004$ & cristalino & 205 & 14,4 & 31 & 117 & 10,0 & 85 & 18 \\
\hline 477 & 1374 & R. DAS BAIADEIRAS, 202 & metalurgica & $\mathrm{NI}$ & 7380830 & 327080 & 726 & $12 / 03 / 2003$ & cristalino & 187 & 14,3 & 80 & 96 & 8,0 & 96 & 8 \\
\hline 478 & $\mathrm{NI}$ & R. DAS BAIADEIRAS, 202 & Metalurgica & $\mathrm{NI}$ & 7380876 & 327071 & $\mathrm{NI}$ & $\mathrm{NI}$ & nao confiavel & $\mathrm{NI}$ & $\mathrm{NI}$ & $\mathrm{NI}$ & $\mathrm{NI}$ & $\mathrm{NI}$ & $\mathrm{NI}$ & $\mathrm{NI}$ \\
\hline 479 & 1198 & R. FERDINANDO FORINO, 42 & Extracao e comercio de agua & Silva Estacas & 7376040 & 326450 & 750 & $16 / 09 / 2002$ & nao confiavel & 200 & $\mathrm{NI}$ & $\mathrm{NI}$ & $\mathrm{NI}$ & $\mathrm{NI}$ & $\mathrm{NI}$ & $\mathrm{NI}$ \\
\hline 480 & 65 & AV. GIOVANI GRONCH,7020 & Imobiliaria & \begin{tabular}{|l|} 
Aguabras \\
\end{tabular} & 7384310 & 322820 & 745 & $17 / 09 / 1975$ & cristalino & 120 & 8,1 & 5 & 60 & $\mathrm{NI}$ & $\mathrm{NI}$ & $\mathrm{NI}$ \\
\hline 481 & 66 & AV. GIOVANI GRONCH, 7020 & Imobiliaria & Air Lift & 7384260 & 322850 & 745 & 14/09/1990 & cristalino & 130 & 6,5 & 24 & 49 & $\mathrm{NI}$ & $\mathrm{NI}$ & $\mathrm{NI}$ \\
\hline 482 & 1425 & R. DOM AGUIRRE, 607 & Eletro-eletronica & $\mathrm{NI}$ & 7382380 & 327830 & 750 & abr-02 & cristalino & 210 & 2,8 & 29 & 140 & 2,8 & 140 & 20 \\
\hline 483 & 217 & R. AMOIPIRA, 81 & Fabricacao de lampadas & Corner & 7381370 & 327600 & 742 & $17 / 04 / 1958$ & nao confiavel & 200 & $\mathrm{NI}$ & $\mathrm{NI}$ & $\mathrm{NI}$ & 6,0 & 90 & 20 \\
\hline 484 & 218 & R. AMOIPIRA, 81 & Fabricacao de lampadas & Corner & 7381290 & 327680 & 742 & \begin{tabular}{|l}
$174 / 1958$ \\
\end{tabular} & nao confiavel & 192 & $\mathrm{NI}$ & $\mathrm{NI}$ & $\mathrm{NI}$ & 10,0 & 120 & 20 \\
\hline 485 & $\mathrm{NI}$ & ESTRADA SÃO FRANCISCO & energia eletrica & $\mathrm{NI}$ & 7387550 & 318880 & $\mathrm{NI}$ & $\mathrm{NI}$ & nao confiavel & $\mathrm{NI}$ & $\mathrm{NI}$ & $\mathrm{NI}$ & $\mathrm{NI}$ & $\mathrm{NI}$ & $\mathrm{NI}$ & $\mathrm{NI}$ \\
\hline 486 & $\mathrm{NI}$ & ESTRADA SÃO FRANCISCO & energia eletrica & $\mathrm{NI}$ & 7387340 & 318740 & $\mathrm{NI}$ & $\mathrm{NI}$ & nao confiavel & $\mathrm{NI}$ & $\mathrm{NI}$ & $\mathrm{NI}$ & $\mathrm{NI}$ & $\mathrm{NI}$ & $\mathrm{NI}$ & $\mathrm{NI}$ \\
\hline 487 & $\mathrm{NI}$ & R. ROQUE PETRONE JR. , 1464 & Servicos & $\mathrm{NI}$ & 7386840 & 326690 & $\mathrm{NI}$ & $\mathrm{NI}$ & nao confiavel & $\mathrm{NI}$ & $\mathrm{NI}$ & $\mathrm{NI}$ & $\mathrm{NI}$ & $\mathrm{NI}$ & $\mathrm{NI}$ & $\mathrm{NI}$ \\
\hline 488 & $\mathrm{NI}$ & AV. GUARAPIRANGA, 900 & Comercio alimenticios & $\mathrm{NI}$ & 7381810 & 324280 & $\mathrm{NI}$ & $\mathrm{NI}$ & nao confiavel & $\mathrm{NI}$ & $\mathrm{NI}$ & $\mathrm{NI}$ & $\mathrm{NI}$ & $\mathrm{NI}$ & $\mathrm{NI}$ & $\mathrm{NI}$ \\
\hline 489 & 1059 & AV. SANTA. CATARINA, 182 & Manutencao de veiculos & $\mathrm{NI}$ & 7384760 & 329620 & 780 & $\mathrm{NI}$ & nao confiavel & 36 & $\mathrm{NI}$ & $\mathrm{NI}$ & $\mathrm{NI}$ & $\mathrm{NI}$ & $\mathrm{NI}$ & $\mathrm{NI}$ \\
\hline 490 & $\mathrm{NI}$ & R. ENG. MESQUITA SAMPAIO, 714 & Metalurgica (rolamentos) & $\mathrm{NI}$ & 7386040 & 326200 & $\mathrm{NI}$ & $\mathrm{NI}$ & nao confiavel & $\mathrm{NI}$ & $\mathrm{NI}$ & $\mathrm{NI}$ & $\mathrm{NI}$ & $\mathrm{NI}$ & $\mathrm{NI}$ & $\mathrm{NI}$ \\
\hline 491 & 1740 & R. DR. FERREIRA LOPES, $97 / 143$ & Metalurgica & $\mathrm{NI}$ & 7382530 & 326920 & 740 & $22 / 11 / 2003$ & $\mathrm{NI}$ & 101 & 5,6 & 10 & 14 & 4,0 & 13 & 20 \\
\hline 492 & 1690 & R. CENTRO AFRICANA, 219 & Quimica-Farmaceutica & $\mathrm{NI}$ & 7384270 & 324215 & 725 & \begin{tabular}{|l}
$\mathrm{NI}$ \\
\end{tabular} & nao confiavel & 129 & 9,9 & 25 & 34 & 9,1 & 33 & 3 \\
\hline 493 & 1341 & R. DR. PASCHOAL IMPERATRIZ, 192 & Escritorios & Geopesquisadora & 7386650 & 327020 & 727 & $\mathrm{NI}$ & nao confiavel & 380 & 12,0 & 56 & 150 & 10,0 & 135 & 22 \\
\hline 494 & 1342 & R. DR. PASCHOAL IMPERATRIZ,192 & Escritorios & Geopesquisadora & 7386560 & 327840 & 736 & $11 / 03 / 1996$ & cristalino & 390 & 6,0 & 43 & 140 & 6,0 & 98 & 22 \\
\hline 495 & $\mathrm{NI}$ & R. DR. PASCHOAL IMPERATRIZ, 192 & Escritorios & $\mathrm{NI}$ & 7386660 & 327840 & $\mathrm{NI}$ & $30 / 09 / 2004$ & nao confiavel & $\mathrm{NI}$ & $\mathrm{NI}$ & $\mathrm{NI}$ & $\mathrm{NI}$ & 6,0 & $\mathrm{NI}$ & 20 \\
\hline
\end{tabular}




\begin{tabular}{|c|c|c|c|c|c|c|c|c|c|c|c|c|c|c|c|c|}
\hline \multicolumn{17}{|c|}{ ANEXO - CADASTRO DE POÇOS - Conclusão } \\
\hline $\begin{array}{l}\text { No.-de- } \\
\text { poços }\end{array}$ & $\begin{array}{l}\text { Poco- } \\
\text { DAEE }\end{array}$ & Endereco & Atividade & Cia_Perfuradora & N & E & Cota $(m)$ & Data_Const & Aquifero & Prof-(m) & \begin{tabular}{|l|} 
Teste- \\
Vazao- \\
(m3/h)
\end{tabular} & $\begin{array}{l}\text { TesteN } \\
E(\mathrm{~m})\end{array}$ & \begin{tabular}{|l|} 
TesteN \\
$\mathrm{D}(\mathrm{m})$
\end{tabular} & \begin{tabular}{|l|} 
Vazao- \\
Explor- \\
(m3/h)
\end{tabular} & \begin{tabular}{|l|} 
ND- \\
explor- \\
(m)
\end{tabular} & $\begin{array}{l}\text { Horas- } \\
\text { Exp }\end{array}$ \\
\hline 496 & 1578 & R. DOM AGUIRRE, 458 & Fabricacao plastico & $\mathrm{NI}$ & 7382450 & 327980 & 746 & $\mathrm{NI}$ & nao confiavel & 150 & $\mathrm{NI}$ & $\mathrm{NI}$ & $\mathrm{NI}$ & $\mathrm{NI}$ & $\mathrm{NI}$ & $\mathrm{NI}$ \\
\hline 497 & 4 & R. DO NIQUEL, 90 & Extracao e comercio de agua & Air Lift & 7385980 & 328180 & 740 & $26 / 08 / 1988$ & misto 3 & 176 & 22,0 & 39 & 47 & $\mathrm{NI}$ & $\mathrm{NI}$ & $\mathrm{NI}$ \\
\hline 498 & $\mathrm{NI}$ & R. JORGE DUPRAT FIGUEIREDO , 148 & Garagem & $\mathrm{NI}$ & 7384370 & 330700 & $\mathrm{NI}$ & $\mathrm{NI}$ & nao confiavel & $\mathrm{NI}$ & $\mathrm{NI}$ & $\mathrm{NI}$ & $\mathrm{NI}$ & $\mathrm{NI}$ & $\mathrm{NI}$ & $\mathrm{NI}$ \\
\hline 499 & 395 & AV. LUIZ CARLOS BERRIII, 1902 & Servicos de comunicacao & Hidrogeo & 7387430 & 327030 & 727 & $20 / 03 / 1998$ & nao confiavel & 252 & 0,7 & 21 & 210 & 0,7 & 210 & 18 \\
\hline 500 & $\mathrm{NI}$ & AV. LUIZ CARLOS BERRINI, 1902 & Servicos de comunicacao & $\mathrm{NI}$ & 7387430 & 327430 & $\mathrm{NI}$ & $23 / 10 / 1998$ & nao confiavel & $\mathrm{NI}$ & $\mathrm{NI}$ & $\mathrm{NI}$ & $\mathrm{NI}$ & 0,7 & $\mathrm{NI}$ & 20 \\
\hline 501 & $\mathrm{NI}$ & R. ARNALDO MAGNICARRO, 521 & Fabricacao plastico & $\mathrm{NI}$ & 7380746 & 327396 & $\mathrm{NI}$ & $\mathrm{NI}$ & $\mathrm{NI}$ & $\mathrm{NI}$ & $\mathrm{NI}$ & $\mathrm{NI}$ & $\mathrm{NI}$ & $\mathrm{NI}$ & $\mathrm{NI}$ & $\mathrm{NI}$ \\
\hline 502 & 1051 & R. RODRIGUES DE MEDEIROS , 214 & metalurgica & Geoplan & 7377930 & 330720 & $\mathrm{NI}$ & $\mathrm{NI}$ & cristalino & 300 & 6,6 & 44 & 204 & 6,0 & 190 & 15 \\
\hline 503 & $\mathrm{NI}$ & $\mathrm{NI}$ & Consultoria & $\mathrm{NI}$ & 7383280 & 327770 & $\mathrm{NI}$ & $\mathrm{NI}$ & $\mathrm{NI}$ & $\mathrm{NI}$ & $\mathrm{NI}$ & $\mathrm{NI}$ & $\mathrm{NI}$ & $\mathrm{NI}$ & $\mathrm{NI}$ & $\mathrm{NI}$ \\
\hline 504 & $\mathrm{NI}$ & AV. ADOLFO PINHEIRO, 1500 & alimentacao e bebidas & $\mathrm{NI}$ & 7384630 & 326960 & $\mathrm{NI}$ & $\mathrm{NI}$ & nao confiavel & $\mathrm{NI}$ & $\mathrm{NI}$ & $\mathrm{NI}$ & $\mathrm{NI}$ & $\mathrm{NI}$ & $\mathrm{NI}$ & $\mathrm{NI}$ \\
\hline 505 & 194 & AV. GUIDO CALOI, 1200 & Garagem & Politi & 7381840 & 323820 & 726 & $24 / 06 / 1994$ & cristalino & 109 & 46,6 & 10 & 49 & 40,0 & 44 & 15 \\
\hline 506 & 1346 & R. AGOSTINHO TOGNERI, 421 & Fabricação alimentícios & Aguabras & 7380780 & 327170 & 726 & $01 / 01 / 1992$ & cristalino & 184 & 3,1 & 85 & 133 & 3,0 & 131 & 18 \\
\hline 507 & 738 & R. ITAPAIUNA, 1800 & Servicos (loja de mat const) & \begin{tabular}{|l} 
Jundsondas \\
\end{tabular} & 7384910 & 323710 & 727 & $31 / 01 / 2000$ & misto2 & 192 & 38,6 & 6 & 40 & 5,0 & 11 & 17 \\
\hline 508 & $\mathrm{NI}$ & R. ITAPAIUNA, 1800 & Servicos (loja de mat const) & $\mathrm{NI}$ & 7384910 & 323520 & $\mathrm{NI}$ & $22 / 02 / 2002$ & nao confiavel & $\mathrm{NI}$ & \begin{tabular}{|l|l|l|l}
$\mathrm{NI}$ \\
\end{tabular} & $\mathrm{NI}$ & $\mathrm{NI}$ & 5,0 & $\mathrm{NI}$ & 17 \\
\hline 509 & $\mathrm{NI}$ & R. PROF. HILARIO VEIGA DE CARVALHO , 100 & Clubes e similares & $\mathrm{NI}$ & 7386950 & 322710 & $\mathrm{NI}$ & $\mathrm{NI}$ & nao confiavel & $\mathrm{NI}$ & $\mathrm{NI}$ & $\mathrm{NI}$ & $\mathrm{NI}$ & $\mathrm{NI}$ & $\mathrm{NI}$ & $\mathrm{NI}$ \\
\hline 510 & $\mathrm{NI}$ & R. ADA NEGRI, 469 & Servicos (aluguel de toalhas) & $\mathrm{NI}$ & 7383510 & 325010 & $\mathrm{NI}$ & $12 / 02 / 2003$ & nao confiavel & $\mathrm{NI}$ & $\mathrm{NI}$ & $\mathrm{NI}$ & $\mathrm{NI}$ & 1,0 & $\mathrm{NI}$ & 5 \\
\hline 511 & $\mathrm{NI}$ & R. ROQUE PETRONE JR., 1464 & Imobiliaria & $\mathrm{NI}$ & 7386840 & 326490 & $\mathrm{NI}$ & $25 / 06 / 2004$ & nao confiavel & $\mathrm{NI}$ & $\mathrm{NI}$ & $\mathrm{NI}$ & $\mathrm{NI}$ & 5,0 & $\mathrm{NI}$ & 16 \\
\hline 512 & 1635 & R. AUGUSTO FERREIRA DE MORAES, 618 & Metalurgica & Terra sol & 7381448 & 324775 & 725 & $\mathrm{NI}$ & cristalino & 150 & 7,0 & 66 & 130 & 7,0 & 130 & 24 \\
\hline 513 & 601 & AV. DO JANDADEIRO, 219 & alimentacao e bebidas & Outras & 7377300 & 326620 & 730 & $\mathrm{NI}$ & sedimentar & 63 & 2,0 & 20 & 58 & 2,0 & 58 & 20 \\
\hline
\end{tabular}

